


\section{THE MEDIATION OF EMOTIVE SCRIPTS}

A Cross-Cultural Study of Poetic Imagery, Gestures, and Emotion in Chrétien de Troyes's Yvain and its Medieval Translations

Chloé Vondenhoff 
Copyright (C) Chloé Vondenhoff, Utrecht, 2021

All rights reserved. No part of this publication may be reproduced in any form without written permission of the author.

Cover image: Detail from Iwein fresco, Rodenegg Castle, South Tyrol, early $13^{\text {th }}$ century, depicting Laudîne and her courtiers bewailing their dead lord. Photo by courtesy of Prof. dr. Jozef Janssens.

Cover design: Ridderprint | www.ridderprint.nl

Printing: Ridderprint | www.ridderprint.nl

ISBN: 978-94-6416-625-5 


\title{
THE MEDIATION OF EMOTIVE SCRIPTS
}

\section{A Cross-Cultural Study of Poetic Imagery, Gestures, and Emotion in Chrétien de Troyes's Yvain and its Medieval Translations}

\author{
De vertaler als bemiddelaar. Een cross-culturele studie naar de weergave van \\ emoties in de verschillende middeleeuwse versies van het Yvain-verhaal \\ (met een samenvatting in het Nederlands)
}

\section{Proefschrift}

ter verkrijging van de graad van doctor aan de Universiteit Utrecht op gezag van de rector magnificus, prof.dr. H.R.B.M. Kummeling, ingevolge het besluit van het college voor promoties in het openbaar te verdedigen op vrijdag 11 juni 2021 des middags te 2.15 uur

door

\section{Chloé Henrica Anna Gerarda Vondenhoff}

geboren op 19 januari 1988

te Heerlen 


\section{Promotoren:}

Prof.dr. A.A.M. Besamusca

Prof.dr. S. Ríkharðsdóttir

\section{Copromotor:}

Dr. F.P.C. Brandsma

The degree is awarded as part of a Joint Doctorate with the University of Iceland.

Dit proefschrift werd (mede) mogelijk gemaakt met financiële steun van the University of Iceland Research Fund en the Icelandic Research Fund (Rannís). 


\section{CONTENTS}

INTRODUCTION

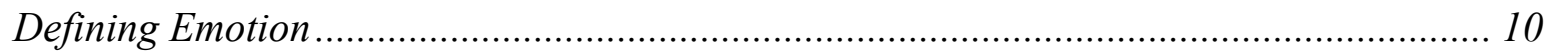

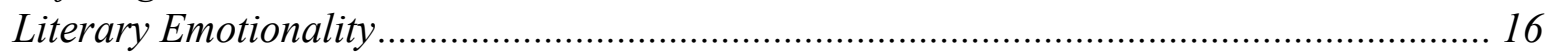

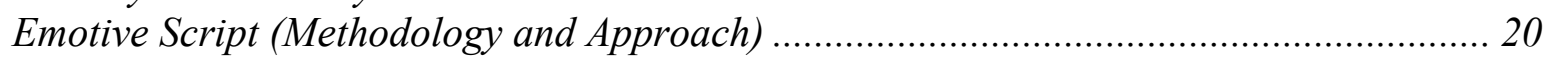

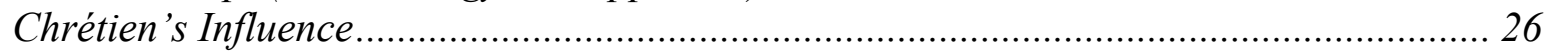

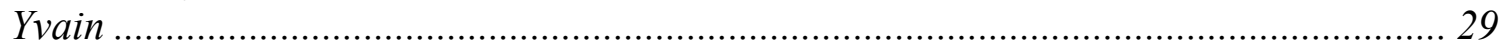

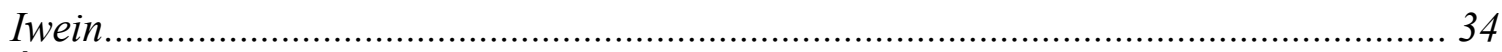

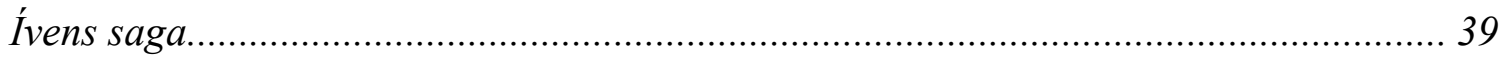

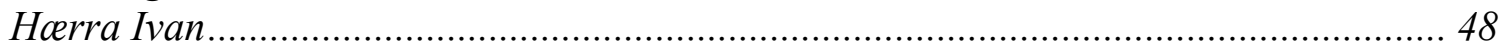

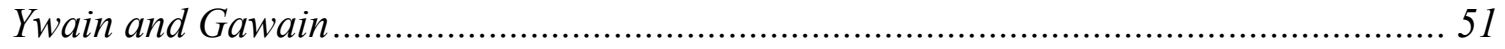

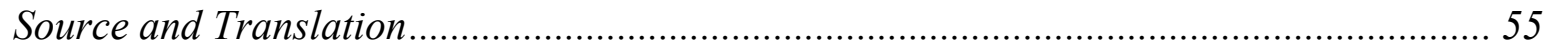

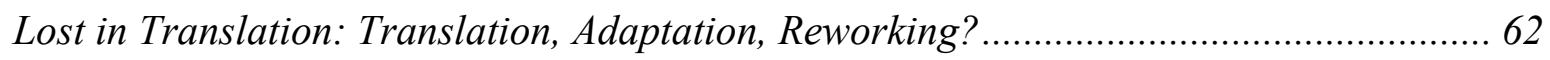

The Translator as Mediator of Literary Cultures ........................................................... 68

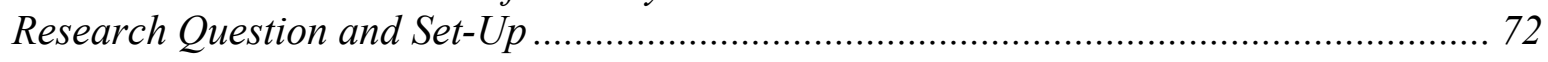

CHAPTER ONE: MEDIATING POETIC IMAGERY Matter(s) of the Heart in Yvain

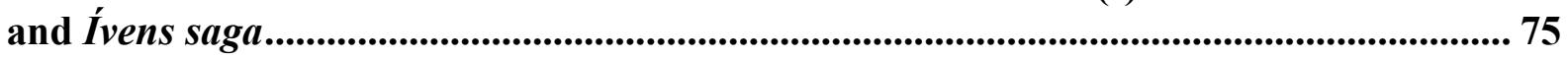

Heart-Imagery in French Courtly Romance ................................................................. 78

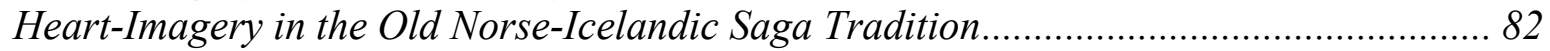

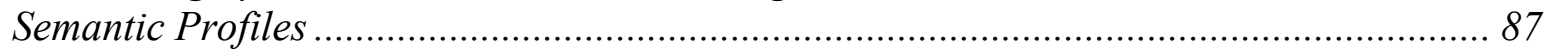

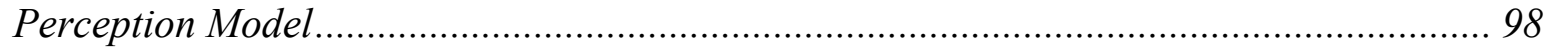

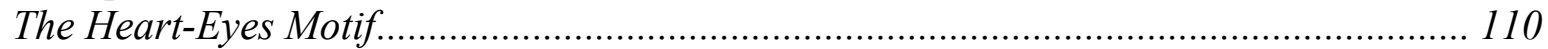

The Itinerant Heart Motif........................................................................................... 124

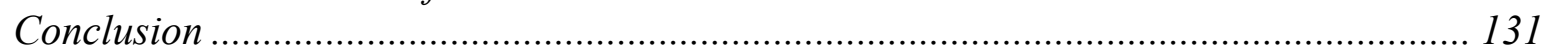

\section{CHAPTER TWO: MEDIATING PERFORMATIVE ACTION AND SPEECH}

Reconciling Lovers in Yvain and Iwein ......................................................................... 137

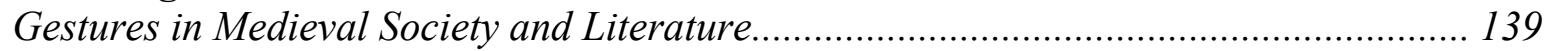

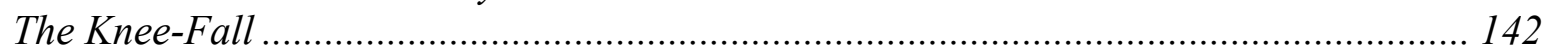

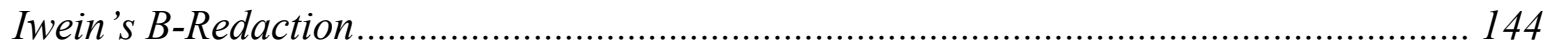

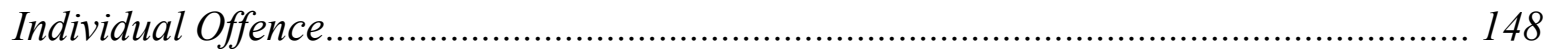

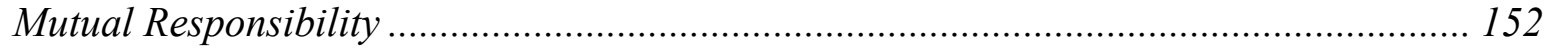

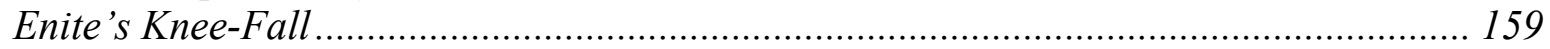

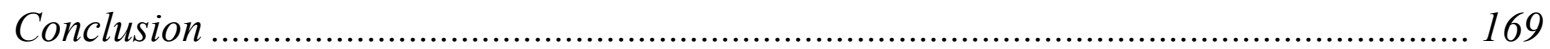

CHAPTER THREE: MEDIATING IMAGES OF COLLECTIVE EMOTION The

Construction of the Communal Feeling in Yvain, Ívens saga and Ywain and Gawain... 172

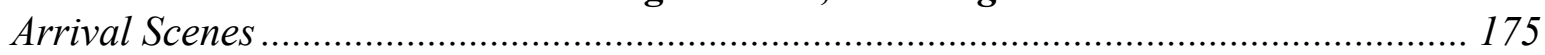

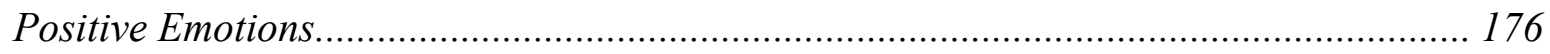

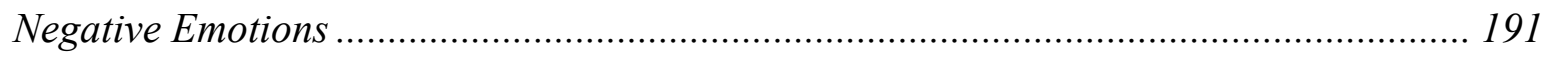

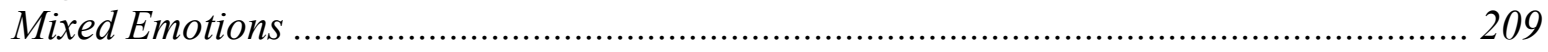

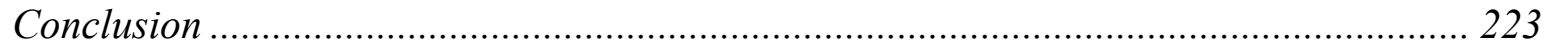


CONCLUSION

BIBLIOGRAPHY

236

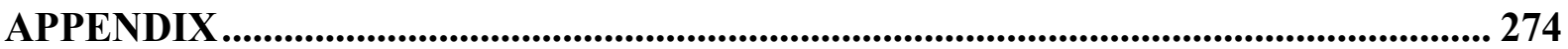

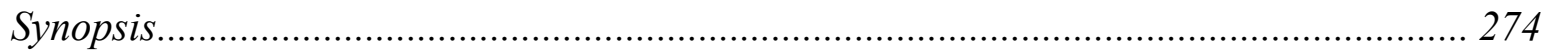

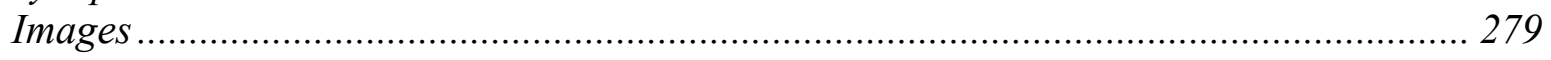

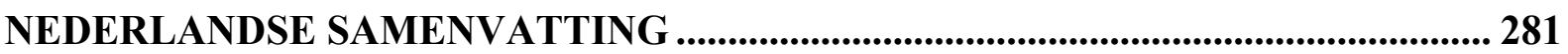

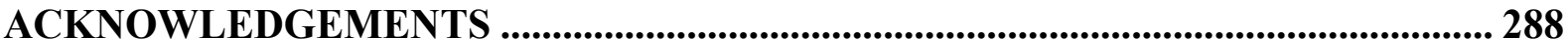

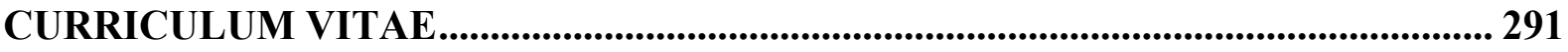




\section{INTRODUCTION}

'One of the virtues of studying Arthurian literature is that it provides an ample and coherent matter in which to chart developments in the narrative articulation of emotion over many languages, cultures, genres and centuries', is what medievalist Andrew Lynch concludes in his introduction to a cluster of articles on positive emotions in Arthurian romance. ${ }^{1}$ Indeed, emotion plays a significant role in Arthurian romances and seems to be a major feature of these narratives. Originating within the context of late twelfth century court life, the Arthurian romance has been found to reflect the contemporary refinement of sentiment and to echo corresponding emotional codes. That is why the study of literary emotion is a thriving subject area within Arthurian studies, a field of research that since the 'affective turn' has greatly contributed to the history of emotion. ${ }^{2}$

The Arthurian corpus created by the northern French court poet Chrétien de Troyes has particular comparative potential for a cross-cultural study of the narrative articulation of emotion. Not only do his romances contain explicit verbalisations and gesticulations of emotions that have a high emotive potential for their audiences, they were moreover adopted into multiple European literary traditions. Chrétien's Yvain ou le chevalier au lion (c. 11701190) especially offers a suitable textual sample for a comparative study of emotion and narration, since it was translated into diverse vernaculars relatively shortly after being composed. Correspondences and deviations in the literary representation of emotion can

\footnotetext{
1 'Positive Emotions in Arthurian Romance: Introduction', Journal of the International Arthurian Society 4.1 (2016), 53-57, at 57.

2 Broadly defined, the so-called 'affective turn' marks the newfound interest in the study of affect in the humanities and social sciences that has sparked a range of exploratory studies on emotions, feelings, passions and moods from the 1990 s until today.
} 
easily be traced across these different renditions that are known for their general faithfulness to the Old French source.

This dissertation presents a cross-cultural study of the first generation translations of Yvain that came about from the early thirteenth until the early fourteenth century: the Middle High German Iwein (1204), the Old Norse-Icelandic Ívens saga (c. 1250), the Old Swedish Hoerra Ivan (1303), and the Middle English Ywain and Gawain (c. 1300-1350).

Methodologically, the study draws on the latest insights in emotion studies, particularly with respect to literary emotionality and audience reception. It adopts the recently developed theoretical approach of analysing and comparing these narratives by means of their underlying emotive script. ${ }^{3}$

Together with the emotional lexis of a text, an emotive script is made up of generically predetermined emotional codes that constitute ways of narrating emotion and acts in some sense as a literary blueprint for the representation of emotionality. Whilst subject to change, these generic conventions for the representation of emotion within a literary work prescribe its medium as well as those narrative strategies that help make its representation meaningful to the targeted audience. The literary means for displaying emotionality have been shown to deviate between literary traditions, sometimes quite significantly. Norse saga audiences, for example, brought a different literary framework and set of expectations to a narrative than French romance audiences.

This meant that, along with the introduction of the story of Yvain to other European textual traditions, came foreign linguistic and cultural codes that will very likely have included emotional signifying systems that were distinctly different from those existing in the newly targeted cultures. This dissertation sheds light on this textual transferral (translatio)

\footnotetext{
${ }^{3}$ As recently theorised by Sif Rikhardsdottir in Emotion in Old Norse Literature: Translations, Voices, Contexts (Cambridge: D.S Brewer, 2017).
} 
and explores what happens when emotive scripts of different literary traditions meet in the process of cross-cultural translation. How have the different textual traditions rendered any unfamiliar representations in the process of adapting the story to new literary contexts? What linguistic, (socio-)cultural and/or generic divergences regarding the literary representation of emotion does a comparative close reading of these narratives bring to light? More specifically, how did translators 'mediate' any incompatibilities between emotive scripts into meaningful renditions for their audiences?

Because of the large corpus analysed in this study as well as the variable nature that literary emotionality is subject to, each analytical chapter takes on the form of a comparative case study. In addition to discussing different vernacular literary traditions, each case study highlights varying narrative strategies for the scripting of emotion. Chapter one examines poetic imagery and metaphorical representations of the heart in Yvain and Ívens saga, occasionally drawing on Hoerra Ivan as well. Whereas chapter one focuses on the metaphorical conceptualisation of inner emotion, chapter two demonstrates its physical manifestation. The chapter foregrounds the emotional behaviour of characters as mediated through gesture and speech in Yvain and Iwein. In addition to studying emotion as an individual phenomenon, chapter three explores the representation of collective emotions for Yvain, Ívens saga and the Middle English Ywain and Gawain. It investigates the way the communal feeling is staged and exploited in each of these versions of the story.

Chrétien's narrative is the starting point for each chapter, although the comparison does not stop at 'source' and 'translation' and takes place between the different Yvaintranslations themselves (chapters one and three), and whenever relevant, is extended towards those translations of Chrétien's other romances believed to have been adapted for corresponding reading communities (chapters one and two). In the process of answering the above-posed questions, the following chapters will also touch upon larger issues within 
emotion-, translation-, and medieval studies in their exploration of how to define (literary) emotion, medieval translation practices and medieval textual transmission.

\section{Defining Emotion}

Defining emotion presents a practical as well as a theoretical challenge. Being both subjective in their experience and expression, emotions defy a fixed formulation. The term emotion is a denominator for a complex set of phenomena that can be said to encompass affect, body and cognition. In our everyday usage of the word, 'emotion' is generally deployed to describe the internal feelings and desires, sentiments and moods as well as situational behavioural reactions of a person. The boundaries between these concepts often prove to be 'fuzzy'. Does 'love' for example count as an emotion? Is tension an emotion, or conversely, is calmness? Is an emotion always individually experienced, or can it belong to a group? And if so, is emotion of private or of public value? Within the various scientific fields of biology, psychology, neurology, anthropology and philosophy, emotions are therefore a highly contested subject. The numerous approaches and methods developed over the years on how to study emotions have led to conflicting theories within and across disciplines. The variable and ever-shifting meaning of emotion makes it a difficult research subject to demarcate.

Although the concept itself is a modern invention, the emotions - that is to say, their exact nature, origin and functions - were already disputed in ancient and medieval accounts and treatises. Emotion theories of this kind were developed by philosophical thinkers and theologians, particularly within the Stoic and Epicurean philosophies of the Hellenistic era and later Latin traditions. ${ }^{4}$ In search of the appropriate nomenclature that covered both the

\footnotetext{
${ }^{4}$ Simo Knuuttilla, Emotions in Ancient and Medieval Philosophy (Oxford: Oxford University Press, 2004), 4780.
} 
mental and bodily phenomena that they were experiencing, these early thinkers relied on different categorisations. Instead of the umbrella term 'emotions' we have settled on today-a term that is believed to have entered our vocabulary as late as the seventeenth century and only came into being as a distinct psychological category during the nineteenth centurymany different typologies were circulating. ${ }^{5}$

Aristotle recognised several different emotion types (pathé) that are identified as either pleasures or pains, although the numbers differ between his Ëthika Nikomacheia (Nicomachean Ethics) and Rhētorikè (Rhetoric). ${ }^{6}$ Although presented as desires, they are at the same time described as being susceptible to rational influence and voluntary action. While the Greek Stoics tried to avoid the effects of these pathé, Latin philosophers and theologians speculated over the passiones. In Tusculanae Disputationes (Tusculan Disputations) Cicero speaks of perturbationes instead, a term later adopted by Augustine of Hippo. ${ }^{7}$ Although building on Cicero's categorisation of feelings, as well as Aristotle's thoughts on the voluntary nature of emotions, St Augustine at the same time broke with the classical tradition by placing ancient ideas about the emotions in a Christian context. His De civitate Dei (The City of God, especially Book 9 and14), as well as Confessiones (Confessions) and De libero arbitrio (On Free Choice of the Will), offer lengthy discussions of the passions and affections

\footnotetext{
5 Thomas Dixon, From Passions to Emotions: The Creation of a Secular Psychological Category (Cambridge: Cambridge University Press, 2003). The term is believed to derive from Descartes, who used the term émotion to indicate 'disturbance' and used it as a synonym for the passions of the soul (13).

${ }^{6}$ Jamie Dow, 'Aristotle's Theory of the Emotions: Emotions as Pleasures and Pains', in Moral Psychology and Human Action in Aristotle, ed. Michael Pakaluk and Giles Pearson (New York: Oxford University Press, 2011), $48-74$.

${ }^{7}$ For a list of Cicero's perturbations see Barbara H. Rosenwein, Generations of Feeling: A History of Emotions 600-1700 (Cambridge: Cambridge University Press, 2016), 16-24. For a list of Augustine's passiones see Rosenwein, Generations of Feeling, 24-34.
} 
that are presented as unruly forces of the soul. ${ }^{8}$ These writings became widely spread through their discussion by Thomas of Aquinas in his Summa Theologice (Summary of Theology), who can be said to have 'Aristotelianised' his teaching. ${ }^{9}$ Both Augustine and Thomas had a profound impact on the theorising of emotions in the Middle Ages and their teachings provided the basis for further studies by medieval scholars, like St Anselm, Peter Abelard and Jean de la Rochelle, but also for pre-modernists like Thomas Hobbes.

The first modern studies on emotions date from the end of the nineteenth century. Evolutionist Charles Darwin and psychologist William James each described emotions as the result of genetically predetermined stimuli of the nervous system. ${ }^{10}$ These theories were based on the assumption that emotions are physiological sensations resulting in automatic and, moreover, universally shared bodily responses. By analysing and cataloguing human facial expressions, Darwin proposed the theory that the facial expressions and body language that accompany emotion are innate, thus resulting in a set of primary emotions that are moreover shared by human beings across cultures and time. ${ }^{11}$ Behaviourists, like Darwin and James,

\footnotetext{
${ }^{8}$ See for instance Peter King's chapter on 'Emotions in Medieval Thought', in The Oxford Handbook of Philosophy of Emotions, ed. Peter Goldie (Oxford/New York: Oxford University Press, 2010), 167-80.

${ }^{9}$ Dixon, From Passions to Emotions, 28.

${ }^{10}$ Charles Darwin, The Expressions of the Emotions in Man and Animals, 3rd ed. (London: Harper Collins Publishers, 1872, repr. 1998); William James, 'What is an Emotion?', Mind 9 (1884), 188-205.

${ }^{11}$ Since then, multiple neuropsychological studies have investigated human test subjects based on the concept of a universality of emotional expression. These studies have resulted in theories of basic or 'prototypical' emotions that have become widely known through the works of psychologist Paul Ekman (see below) and neuroscientist Antonio Damasio (Damasio, The Feeling of what Happens: Body and Emotion in the Making of
} Consciousness, New York: Harcourt Brace \& Company, 1999). Although not all neuroscientists agree on the number of basic emotions or how they are to be classified, anger and fear, surprise and disgust, joy and sadness tend to be categorised by most as the primary emotions in terms of their universality in the display and recognition of facial expression, see for example Paul Ekman and Wallace V. Friesen, 'Constants across Cultures in the Face and Emotion', Journal of Personality and Social Psychology 17 (1971), 124-29; Ekman, 'Basic Emotions', in Handbook of Cognition and Emotion, ed. Tim Dalgleish and Mick J. Power (Chichester: John Wiley and Sons, 1999), 45-60; Keith Oatley and Philip N. Johnson-Laird, 'The Communicative Theory of 
believe emotions evolved out of natural selection. The emotion 'fear', for instance, triggers an automatic reaction that enhances our chance of survival. When a person comes across a snake, the instinctive response is to run away. According to James, this physiological response comes in first and is the emotion. The brain secondarily reacts to the information received via the body's nervous system. ${ }^{12}$ According to the behaviourists, emotions are therefore innate and the body plays an important part in the manifestation and expression of emotion.

In the mid-twentieth century, the 'natural school' came under criticism by psychologists who favoured a cognitive approach to emotion theory. Psychologist Magda Arnold was one of the first to suggest that having an emotion was preceded by a mental assessment (an appraisal) and that the body comes in secondarily, thereby questioning the universality of human emotion. ${ }^{13}$ Since this 'action readiness' is, according to Arnold, dependent upon personal motivation, it may therefore not take place at all. Applying her appraisal theory to James's snake example, the person encountering the snake could run

Emotions: Empirical Tests, Mental Models, and Implications for Social Interaction', in Striving and Feeling: Interactions among Goals, Affect, and Self-Regulation, ed. Leonard L. Martin and Abraham Tesser (Mahwah, NJ: Erlbaum, 1996), 363-80; Jaak Panksepp, Affective Neuroscience: The Foundations of Human and Animal Emotions (New York/Oxford: Oxford University Press, 1998). The notion of the existence of 'basic emotions' has also been subject to much critique, both within the field of psychology and beyond. It has been challenged by psychologists Andrew Ortony and Terence J. Turner ('What's Basic about Basic Emotions?', Psychological Review 97.3 (1990), 315-31), as well as Karen C. Barrett ('The Development of Nonverbal Communication of Emotion: A Functionalist Perspective', Journal of Nonverbal Behavior 17.3 (1993), 145-69), who have argued that Ekman and others identify only certain genetic components of emotions, rather than genetically programmed emotions. Ekman's suggested 'packaging of affect' has, moreover, been debated by the social sciences that believe that emotions should not be decontextualised as they are deeply connected to social, historical and cultural practices (see Margaret Wetherell, Affect and Emotion: A New Social Science Understanding, London: Sage Publications Ltd., 2012, at 98).

12 James, 'What is an Emotion?', 194. This theory of emotion is now also referred to as the James-Lange theory. Carl Lange proposed similar theories as James' study, but both did so independently ('The Emotions: A Physiological Study', in The Emotions, ed. Carl G. Lange and William James, New York: Hafner, 1885, 33-90).

${ }^{13}$ Magda Arnold, Emotion and Personality, vol.1: Psychological Aspects, vol. 2: Neurological and Psychological Aspects (New York: Columbia University Press, 1960). 
away, but might just as well not run away, depending on the cognitive assessment of the situation. Appraisal theory and the discussion of a motivational precondition for emotion was further developed by psychologists Nico Frijda and Klaus Scherer, who have provided emotion theory with schematic models that help visualise and discuss the sequence of events involved in having an emotion. ${ }^{14}$ Through the exploration of the individual's subjective evaluation of events and situations and the potential socio-cultural influence on this process of interpretation, Arnold's appraisal theory was a forerunner of one of the biggest paradigm shifts in emotion theory so far: social constructionism.

Social constructionists argue that emotions and the way they are expressed are shaped and controlled by the society in which they function. ${ }^{15}$ Theorists maintain that emotion is socially constituted and acknowledge emotions like envy, guilt and romantic love, not found in animals. Although social-constructionists do recognise the natural basis of some emotions, they believe that their expression is mediated and managed by a person's social consciousness. Although rooted in the 1970s, social constructionism did not establish itself until the 1980s. ${ }^{16}$ Anthropology was one of the first fields to question the Darwinian model by

\footnotetext{
${ }^{14}$ Nico H. Frijda, The Emotions, Studies in Emotion and Social Interaction (Cambridge/New York: Cambridge University Press, Paris: Maison des sciences du l'homme, 1986), published in Dutch as De emoties: Een overzicht van onderzoek en theorie (Amsterdam: Bert Bakker, 1988); Frijda, The Laws of Emotion (Mahwah, NJ: Lawrence Erlbaum Associates, 2007); Klaus R. Scherer, Angela Schorr and Tom Johnstone, eds, Appraisal Processes in Emotion: Theory, Methods, Research (New York: Oxford University Press, 2001); Scherer, 'What are Emotions? And How can They be Measured?' Social Science Information 44 (2005), 695-729.

${ }^{15}$ See among others James R. Averill, ‘A Constructivist View of Emotion', in Emotion: Theory, Research, and Experience, ed. Robert Plutchik and Henry Kellerman (New York: Academic Press, 1980), 305-39; Rom Harré, The Social Construction of Emotions (Oxford: Wiley-Blackwell, 1988); Catherine A. Lutz, Unnatural Emotions (Chicago/London: The University of Chicago Press, 1988); Arlie R. Hochschild, 'Emotion Work, Feeling Rules, and Social Structures', American Journal of Sociology 85.3 (1979), 551-75.

${ }^{16}$ With the exception of 1970 forerunners such as Clifford Geertz (The Interpretation of Cultures: Selected Essays, New York: Basic Books, 1973, especially 55-86) this shift in thinking about emotions was not yet scientific, but rather political (Barbara Rosenwein, ed., Anger's Past: The Social Uses of an Emotion in the Middle Ages, Ithaca/London: Cornell University Press, 1998, 236). These developments paved the way for
} 
underlining, instead, the 'social relational, communicative, and cultural aspects' of emotions. ${ }^{17}$ This new focus opened the subject up to other disciplines previously excluded in the study of emotions and provided a framework for how to study emotions within the social sciences and the humanities.

Within medieval studies, this so-called 'affective turn' was signalled in 1998 by Barbara H. Rosenwein's Anger's Past, a volume of essays that broke with the tradition of characterising medieval affect in uniform terms, but instead stressed the need to examine emotions contextually. ${ }^{18}$ Anger's Past inspired a series of publications that provided guidelines on how to identify and understand medieval affect. ${ }^{19}$ Because of the scarcity of historical texts on medieval emotions, many of these studies look to literary texts to gather

philosopher Rom Harré to propose a new scientific theory of emotions that underlined the learned nature of emotions (The Social Construction of Emotions).

${ }^{17}$ Catherine A. Lutz and Geoffrey M. White, 'Anthropology of Emotions', Annual Review of Anthropology 15.1 (1986), 405-36, at 405.

${ }^{18}$ Rosenwein, ed., Anger's Past, especially the introductory and concluding essays by Rosenwein, 1-6 and 233-47. See also the pioneering compilation of essays by a group of scholars from Utrecht University who instigated the study of the emotional life of the Middle Ages, depicted in word, image and sound: R.E.V Stuip and C. Vellekoop, eds, Emoties in de Middeleeuwen (Verloren: Hilversum, 1998). Although not yet studied widely, the historical study of medieval emotions was not entirely a new field. Consider the following pioneers, who have both largely been praised and criticised — by Rosenwein, among others—-for their exclusively negative discussion of emotion with regard to their medieval subjects: Johan Huizinga's, Herfsttij der Middeleeuwen (Amsterdam: Olympus, Atlas Contact, 2017, first published 1919), published in English as The Waning of the Middle Ages (New York: Doubleday Anchor Books, 1954); Norbert Elias's, Über den Prozeß der Zivilisation, 2 vols (Basel: Verlag Haus zum Falken, 1939) and its English translation The Civilising Process: The History of Manners and State Formations and Civilisations, trans. Edmund Jephcott (Oxford: Blackwell, 1994); Marc Bloch, Rois et serfs: Un chapitre d'histoire capétienne (PhD dissertation, Paris, 1920), and its English translation Feudal Society, trans. L.A. Manyon (Chicago: Chicago University Press, 1961).

${ }^{19}$ These included a set of essays by Rosenwein herself, 'Writing Without Fear about Early Medieval Emotions', Early Medieval Europe 10.2 (2001), 229-34 and 'Thinking Historically about Medieval Emotions', History Compass 8.8 (2010), 828-42 and similarly entitled essays, such as Mary Garrison's 'The Study of Emotions in Early Medieval History: Some Starting Points', Early Medieval Europe 10.2 (2001), 243-50 and Stuart Airlie's, 'The History of Emotion and Emotional History', Early Medieval Europe 10.2 (2001), 235-41. 
testimony. ${ }^{20}$ Yet, as the editors of Emotions in Medieval Arthurian Literature point out, 'some degree of distrust in the 'made-upness' of literary texts remains among medieval historians'. ${ }^{21}$ They continue to express their worries (and to some degree rightly so) regarding the incongruence between the historical study of emotion — a study that examines the emotional life of real, albeit historical people — and the study of the emotional life of literary characters. This caveat, however, does not mean that literary emotions should not be studied. The emotions of characters and the way these are rendered, including the emotional language (lexicon, metaphors) used to describe them, are surely imagined, but not randomly so. Fictive representations have to be mediated in such a way that they are recognisable to the interpreter who is reading or listening to a story. This makes literary works a rich domain for the study of emotions.

\section{Literary Emotionality}

While it is a truism that real human emotion and the literary representation of emotion are not necessarily identical, both real-life experience and depictive representation nevertheless inform one another. Literature is, after all, a human construct. The imaginative emotions under examination in this dissertation feature in stories (re)created by humans for other

\footnotetext{
${ }^{20}$ See for instance Carolyne Larrington, 'The Psychology of Emotion and Study of the Medieval Period', Early Medieval Europe 10.2 (2001), 251-56; Stephen Jaeger and Ingrid Kasten, eds, Codierungen von Emotionen im Mittelalter/Emotions and Sensibilities in the Middle Ages (Berlin: De Gruyter, 2003); Gerd Althoff, 'Tränen und Freude: Was interessiert Mittelalter-Historiker an Emotionen?', Frühmittelalterliche Studien 40 (2006), 1-11; Jutta Emming, 'Emotionen als Gegenstand mediävistischer Literaturwissenschaft', Journal of Literary Theory 1.2 (2007), 251-73; Rüdiger Schnell, 'Erzähler - Protagonist - Rezipient im Mittelalter, oder: Was ist der Gegenstand der literaturwissenschaftlichen Emotionsforschung', Internationales Archiv für Sozialgeschichte der deutschen Literatur 33 (2008), 1-50 and Barbara Rosenwein's latest book Generations of Feeling.

${ }^{21}$ Frank Brandsma, Carolyne Larrington and Corinne Saunders, eds, Emotions in Medieval Arthurian Literature: Body, Mind, Voice, Arthurian Studies 83 (Cambridge: D.S. Brewer, 2015), 6.
} 
humans, in such a way that they carry across meaning and have emotive value. Both author and audience play an important role in this meaning-making process.

In order for a literary work to convey meaning, the reader needs to be able to engage emotionally with the story. Literary scholar Norman N. Holland argues that without this emotional engagement literature would simply not exist. He rightly points out that a story only comes alive through the agency of its audience: as the reader/listener engages emotionally with a text, they imbue it with meaning. ${ }^{22}$ The audience's empathetic involvement in a text depends upon the 'readability' of emotions within the narrative, i.e. the ability of a reader to relate to characters' behaviours in terms of their thoughts and feelings and to interpret them within their narrative context. This readability is dependant upon both neurobiological mechanisms and socio-cultural encoding.

Neurobiological mechanisms, for a large part, define how we are able to engage with emotions in literature. By and large, functional areas and networks within the brain give us the innate ability to 'simulate' emotional situations and experiences. Having been of imperative value for humans throughout evolution both in survival and reproduction, the ability to imagine and assess emotional situations has evolved into 'cognitive systems that enable us to participate in these fictional worlds. ${ }^{, 23}$ Holland explains that these systems work

\footnotetext{
${ }^{22}$ Literature and the Brain (Gainesville, Florida: The PsyArt Foundation, 2009), 34-35.

${ }^{23}$ Ibid. 327-28. See also Patrick Colm Hogan, What Literature Teaches Us about Emotion (Cambridge: Cambridge University Press, 2011), 51. Both Holland and Hogan draw on Jaak Panksepp, who has shown the SEEKING system — one of the seven major emotional tendencies of the brain that is integral to our motivation and our desire to explore and understand - to be largely involved in this empathetic involvement of the reader. This is the system assigned by Panksepp to be responsible for the pleasure we derive from our emotional engagement with literary works. The expectation of the experience of pleasure that a person seeks when he or she starts reading a story makes our brain more sensitive to that experience. Thus, when we engage with a narrative, we unconsciously search for those situations and experiences that we can simulate and emotionally engage with (Panksepp, Affective Neuroscience, 1998). Literary theorist Suzanne Keen similarly suggests that a reader's empathetic involvement in the text is contingent on mirror neurons in the brain, that trigger at a sub-
} 
much the same as when empathising with another person's emotions in real-life. ${ }^{24}$ Over time, we form an 'emotional memory' that helps us asses the affective states of the people around us. ${ }^{25}$ We also bring this emotional memory with us to a literary work. It is our emotional framework with which we approach a narrative.

Different parameters can be said to make up this emotional framework: those that are pre-programmed and those that are learned, in life and through literature. According to Holland, the basic emotions have distinct emotional pathways within the brain that partly inform our emotional memory. ${ }^{26}$ Much like Universal Grammar, these are presumably acquired during the critical period when our emotion systems develop. ${ }^{27}$ Patrick Colm Hogan suggests that within the literary world this has led to archetypal motifs ('hero overthrows villain', 'boy gets girl') within narratives that tap into these prototypical emotions. ${ }^{28}$ This allows for a certain universality when reading literary emotions. It is that universality, incidentally, that allowed for the story of Yvain to cross linguistic frontiers to speak to new cultural audiences. In the same manner, this universality allows for the story in its multiple versions to cross diachronic borders as these narratives still resonate with the modern mind.

cortical level 'mirroring emotions' (feelings, as well as, physiological responses) ('A Theory of Narrative Empathy', Narrative 14 (2006), 209-36).

${ }^{24}$ The ability to recognise and understand affective states in oneself and in others is referred to as 'Theory of Mind'. This creative imagination of another's perspective has recently been linked to reading practices and is proving to be a critical tool in understanding (emotions in) literature, see Paula Leverage, Howard Mancing, Richard Schweickert, and Jennifer Marston William, eds, Theory of Mind and Literature (West Lafayette, Indiana: Purdue University Press, 2011).

${ }^{25}$ Holland, Literature and the Brain, 135-36.

${ }^{26}$ Ibid. 379.

${ }^{27}$ Nico Frijda has laid much of the groundwork for examining the programmed nature of the way we interpret and simulate emotions. He beliefs that, like children who are capable of forming the plurals dogs and cats correctly without any instruction, we know how to express and interpret emotions without instruction (De emoties: een overzicht van onderzoek en theorie, Amsterdam: Bert Bakker, 1988, 297).

${ }^{28}$ The Mind and its Stories: Narrative Universals and Human Feeling (Cambridge: Cambridge University Press, 2003). 
Next to these pre-programmed parameters, a person's emotional memory is a construct of emotional experiences that are acquired over time (socio-cultural encoding). Hogan and Holland share the belief that the brain acquires these schemas for interpreting emotion by learning from the environment that provides us with emotional experiences that, over time, become built into our emotional memory. ${ }^{29}$ Apart from individual development, these are largely dependant upon socio-cultural conventions for the expression, prominence and effect of emotions. This means that a reader with, say, a British cultural background will have more difficulty to engage emotionally with a Japanese narrative than a Japanese reader. The average British reader generally does not have detailed knowledge of Japanese cultural practice for the expression of emotion. More importantly, they do not have readerly experience with the way emotions are conveyed and/or evoked in a Japanese narrative. British and Japanese readers do not share, in a sense, the same 'literary emotional memory' that they bring to a text. The same is true for readers from different time periods.

While the representation of emotion in a literary text is firmly rooted in its sociocultural and historical context and may indeed reflect, or at the very least inform upon, the actual emotional conventions of its reading community, the way emotions are staged and expressed in a narrative abides by generic conventions that are specific for each literary tradition. In Emotion in Old Norse Literature, Sif Rikhardsdottir discusses such conventions as 'generically pre-determined emotional codes that act in some sense as a literary blueprint. ... They are integral to the narrative structure as symbolic codes that guide the reader through the signifying network of a text'. ${ }^{30}$ Such encodings constitute ways of narrating emotion.

\footnotetext{
${ }^{29}$ Holland, Literature and the Brain, 185. The social constructedness of our emotional memory has also been addressed by David Bordwell for film narratives in Narration in the Fiction Film (Madison: University of Wisconsin Press, 1985).

${ }^{30}$ Rikhardsdottir, Emotion in Old Norse Literature, 17-18. As Rikhardsdottir rightly points out, the concept of 'genre' is a modern construct and proves rather fluid when discussed in relation to the texts under examination
} 
They prescribe its portrayal in a literary work through the use of a particular medium (verse/prose) and through narrative devices that help make the emotional representation meaningful to the targeted audience. In order to maximise the emotional impact of a text, narratives make use of those strategies that have the most signifying potential for their audiences.

\section{Emotive Script (Methodology and Approach)}

Rikhardsdottir suggests that together with the emotional lexis of any given language these narrative conventions for the representation of emotionality within a literary work make up a text's 'emotive script'. ${ }^{31}$ The term is an adaptation of psychologist Silvan Tomkin's emotion script - a concept used to develop his 'script theory' in the late 1970s - that denotes the innate affective mechanism that dictates human emotive behaviour. ${ }^{32}$ By adjusting the term to feature emotive scripts, rather than the more human-oriented emotion scripts proposed by

here. Although, when viewed from a modern perspective, all versions can be said to belong to the romance genre, such categorisation does not include narration style or medium and does not apply beyond subject matter. French courtly romance and the Old Norse-Icelandic riddarasögur tradition, for example, adhere to completely different guidelines with respect to the way in which emotions are staged and expressed as they belong to vastly different literary traditions that are furthermore situated in diverse cultural and political environments. Rather than a genre, 'romance' is therefore understood in this study as a literary platform for the encounter of these environments and their literary conventions.

${ }^{31}$ Rikhardsdottir, Emotion in Old Norse Literature, 36. Carolyne Larrington similarly speaks of 'emotion scripts', literary models of 'emotion simulation', 'which, if effectively implemented in terms of characters, behaviour, and situation, will elicit both empathy and aesthetic appreciation in the listening audience' ('Learning to Feel in the Old Norse Camelot?', in Arthur of the North: Histories, Emotions, and Imaginations, ed. Bjørn Bandlien, Stefka G. Eriksen and Sif Rikhardsdottir, special issue of Scandinavian Studies 87.1 (2015), 74-94, at 75).

32 'Script Theory: Differential Magnification of Affects', in Nebraska Symposium on Motivation 1978, 26, ed. Herbert E. Howe and Richard A. Dienstbier (Lincoln: University of Nebraska Press, 1979), 201-36. Psychologists frequently speak of emotion scripts, by which they mean the circumstances that give rise to an emotion and the bodily actions and facial expressions that accompany it. 
Tomkin, Rikhardsdottir shifts this meaning to signify a narrative framework that prescribes the representation of emotion in a literary work.

'Emotive' signals meaning as the adjective 'appealing to or expressing emotion'. It has moreover acquired meaning as a communicative construct through William Reddy's discussion of 'emotives' in his paradigmatic 1997 article 'Against Constructionism'. ${ }^{33}$ In this article, Reddy attempts to formulate a new vocabulary for the expression of emotion. He sets emotion, a private experience, off against emotive, as the public expression of feelings, manifested in actual language or body language. He shows how, unlike emotions, which are intrinsic, 'emotives' are extrinsic and have a signifying function. They do not convey the actual emotion itself (which is, according to Reddy inexpressible), but are a representation of emotion in the form of overlearned habits that function to communicate emotion. According to Reddy, this representation is prescribed by a set of (socio-cultural) rules for emotive behaviour which he refers to as 'emotional styles', that may be subject to change, whenever they are introduced to new conventions regarding the expression of emotions. ${ }^{34}$

In Emotion in Old Norse Literature, Rikhardsdottir presents an insightful example as to how such a prescriptive set of rules for emotive representation exists for literature. She exemplifies how such rules may deviate between literary traditions by setting off the excessive emotional narrative style of the French romance tradition against the indirect and more implicit representation of emotion of the Icelandic saga tradition for feminine

\footnotetext{
33 'Against Constructionism: The Historical Ethnography of Emotions', Current Anthropology 38.3 (1997), $327-$ 51. Although Reddy coins the term 'emotives' in order to argue 'against constructionism' — as the title of the article clearly denotes - it is ironically the partly constructive nature of the expression of emotives that lend them to cultural and historical analysis, as is pointed out by anthropologist Linda C. Garro. She shows in her response to the article that what Reddy is really arguing against is a fairly 'strong' or 'pure' constructionist stance (at 341).

${ }^{34}$ The theory of 'emotional styles' is further explored in Reddy's book The Navigation of Feeling: A Framework for the History of Emotions (Cambridge: Cambridge University Press, 2001).
} 
bereavement behaviour. In describing the exorbitant grief displayed by Laudine (the main female character of Yvain, see Appendix, Synopsis, episode II) when her husband is killed by Yvain in single combat, she notes:

What stands out from this passage is the dual representation of Laudine's sorrow through voice and body. She vocalises her grief by crying out repeatedly and later by lamenting her husband's death. The presumed internal sorrow is embodied by quite literally displaying it on the body, through the torn hair, scratched face and rent clothes, all standard representations of female grieving in the romance tradition. While the text refers to her 'duel' (grief), a presumably internal condition, this interiority is nevertheless only made available through external exhibitors, that is, through vocalisation and embodiment. ${ }^{35}$

Conversely, Rikhardsdottir notes, Guðrun Ósvífsdóttir, one of the characters of the Icelandic Laxdola saga, shows no such explicit signs of female lament, but only smiles at one of her husband's killers while he uses her shawl to wipe his weapon clean. Similarly, in BrennuNjáls saga, Hallgerðr Höskuldsdóttir laughs in the face of her husband's killer when confronted with his death. ${ }^{36}$ Although the expectations of the modern reader are not met with

\footnotetext{
${ }^{35}$ Rikhardsdottir, Emotion in Old Norse Literature, 39.

${ }^{36}$ Ibid. chapter 4. For a discussion of these deviating demonstrations of grief see moreover Rikhardsdottir, 'Translating Emotion in Yvain and Ívens saga', in Emotions in Medieval Arthurian Literature, 161-79. While both text examples represent standard renditions of feminine bereavement behaviour, Rikhardsdottir is aware of the difference in generic context when juxtaposing these two representations. The excessive grief of Laudine is politicised in the feudal setting of French romance, while lamenting a loss is intimately linked to the incitement of revenge ( $h v \ddot{o} t)$ in the saga tradition. The purpose of this comparison is therefore not to draw a comparison of these scenes per se - that come about in different contexts (having the husband' killer as a witness of grief in Yvain versus having to face him directly in Laxdola saga and Brennu-Njáls saga). Rather the intent is to highlight the distinct difference in standard representation of female lament between both traditions in order to
} 
this seemingly laconic reaction-who will probably identify more closely (although not entirely) with the Old French description of Laudine's grief - it does not mean that the sagas are devoid of emotion. Instead, Rikhardsdottir argues, these saga characters signify emotion through the concealment of that emotion, in order to 'actively engage the reader (or audience) in the interpretation of the narrative signals, emotive gesticulations, characters' relationships and intended (and unintended) subtexts. ${ }^{37}$ These saga texts therefore reveal an emotive script that 'favours subtle situational or behavioural hints over explicit verbalisation or gestural behaviour when it comes to emotion' and that conforms to the expectations of its Icelandic audience. $^{38}$

These expectations that a reading community brings to a text regarding its emotional representation is what Rikhardsdottir refers to as the horizon of feeling: 'The 'horizon of feeling' indicates the pre-established readerly expectations of emotional behaviour that determines and/or confirms its generic context and interpretative framework, . . . ${ }^{39}$ Readerly expectations become pre-established through generic conventions. However, generic conventions themselves are dependent upon the literary tastes and predilections (literary preferences) of its intended audience in that moment in time. They are formed by those strategies in the text that have the most signifying value for audiences and that bring about their empathetic involvement in the story. As culture and society continue to evolve, such literary preferences may change over time. The 'horizon of feeling' is thus not 'fixed', but

demonstrate how the two are reconciled in translation. 'It is precisely in the comparison between the two', Rikhardsdottir concludes, 'that the cultural premise of emotional representation can be most fruitfully explored' ('Translating Emotion in Yvain and Ívens saga', 161).

${ }^{37}$ Rikhardsdottir, Emotion in Old Norse Literature, 120-21.

${ }^{38}$ Ibid. 1.

${ }^{39}$ Ibid. 18-19. The 'horizon of feeling' is based on Hans Robert Jauss's Erwartungshorizont, which explains readers' anticipations according to their 'horizon of expectation.' Rikhardsdottir extends Jauss's framework to encompass emotional convention. 
may be supplemented, and ultimately shift, whenever audiences are exposed to new literary traditions containing deviating emotional lexis and differing emotive scripts. ${ }^{40}$

The introduction of French courtly romance to new European reading communities through literary works like Yvain exemplifies such a process of enrichment of literary conventions for the representation of emotion. Rikhardsdottir points out that while we would expect 'a brazen Nordic version of Laudine' who, in the manner of the saga heroines, is ascribed no vocalisation or embodiment except for the purpose of revenge, the Old NorseIcelandic translation, in fact, partly maintains the romance's generic conventions for the representation of grief. ${ }^{41}$ However, while the translation adopts 'the essential semantic elements as described in the French text (mourning, crying and fainting)', its performativity in the demonstration of grief (the tearing at her hair and clawing at her face and clothes) is greatly reduced. ${ }^{42}$ What is more, the vocalisation of Laudine's grief is much subdued, signalling instead a 'perceived emotive interiority': 'hún syrgdi ok æpti sinn harm stundum fell hún i óvit' (50) (she mourned and cried out her sorrow. At times she fell in a faint). ${ }^{43}$ While the semantic elements of the scene have largely remained the same in the process of translation, the narrative mode (i.e. the set of choices through which these elements are narrated) has been rescripted into a rendition that may have been more accessible to the OldNorse Icelandic audience.

This study presents this type of mediation in the staging of emotionality within an adapted story as a reconciliation of emotive scripts. It adopts the concepts emotive scripting and horizon of feeling to be able to discuss and explain, more broadly, the coaction between emotion and narration, as well as those specific instances of emotionality that are examined

\footnotetext{
${ }^{40}$ See Rikhardsdottir, Emotion in Old Norse Literature, 20.

${ }^{41}$ Rikhardsdottir, 'Translating Emotion in Yvain and Ívens saga', 163.

${ }^{42}$ As described in Rikhardsdottir, Emotion in Old Norse Literature, 42-43.

${ }^{43}$ Ibid.
} 
for the Yvain-corpus. Whereas Rikhardsdottir uses the concept of emotive scripts exclusively to examine the literary staging of emotive behaviour, this study will examine the term within a wider emotive spectrum, utilising emotive script as an umbrella term to showcase how deviations in emotive representation between texts belonging to different literary traditions are conditioned by the underlying linguistic, socio-cultural and generic rules for such representation. In addition to the foregrounding of emotive behaviour with regard to gesture and speech (chapter two), this study will examine deviations in the emotive representation of poetic imagery and metaphor (chapter one) as well as in the representation of collective emotions (chapter three). While Rikhardsdottir discusses these concepts for different genres of Old Norse literature in order to tease out deviating standards for the scripting of emotion, this study will have a more narrow focus. It will investigate the (re)drawing of emotionality in different versions of one story, that of Le chevalier au lion, as it was adapted into new literary traditions.

The Yvain-story presents a suitable corpus for such an examination because of its faithful episodic adaptation and the frequently close lexical adaptation into the various vernaculars. ${ }^{44}$ Textual correspondences and deviations in emotive representation can easily be tracked and compared through a close reading of the texts. Any patterns regarding the adoption, or conversely, the redirection of Yvain's narrative conventions that may thus come to light, may, moreover, be compared against the emotive scripts of Chrétien de Troyes's other romances (Erec et Enide and Perceval ou le conte du Graal) that have been adapted cross-culturally for the same reading communities. This seems especially fruitful in the case of the Middle High German Iwein, whose adapter, Hartmann von Aue, also translated the

\footnotetext{
${ }^{44}$ Le chevalier au lion is considered to be an episodic romance. For a discussion of its structure see Zara Patricia Zaddy, 'The Structure of Chrétien's Yvain', The Modern Language Review 65.3 (1970), 523-40. See the synopsis of the story in the Appendix of this study for more information on the structure of Yvain and its division into episodes.
} 
Middle High German version of Erec et Enide (Erec). Both narratives were composed in close proximity to each other and it is likely that they were aimed at the same German audience. The same applies to the Old Norse-Icelandic renditions of Chrétien's stories. Ívens saga, Erex saga and Parcevals saga (including Valvens páttr) are all believed to have been translated at the same court and most likely for the same reading community. When relevant, each chapter in this study will therefore present additional text examples from Chrétien's Erec et Enide and Perceval and their different European renditions in order to support the arguments being offered here on reception-generated reformulation in the process of crosscultural translation.

For a more detailed discussion of the process of cross-cultural translation in the Middle Ages and the human agency involved, this study will turn to the discipline of translation studies as explicated in the section 'The Translator as Mediator of Literary Cultures' below. A detailed description of the corpus that this study looks into will follow first. The following section will shed more light on the dissemination of the story of Yvain across Europe and will provide insight into how and why it crossed linguistic and literary borders. It will illuminate both the literary context and historical background of the texts in the Yvain-corpus under examination in this study, as well as of the rewritings of Erec et Enide and Perceval that each of the chapters brings in for the comparison and substantiation of the texts' emotive scripts.

\section{Chrétien's Influence}

Chrétien de Troyes greatly contributed to the development of Arthurian fiction. His themes and motifs, spatial/temporal framework and overall narrative form served as the example for many romancers and his influence was both profound and long lasting. That is why his 
romances are often named as an important stepping-stone towards the modern novel. Chrétien played a major role in putting new heroes like Yvain, Perceval, Lancelot and Gauvain on the map of European fiction, ascribing to these characters voice, thoughts and feelings. For these reasons, his stories are considered to represent the epitome of courtly romance as a genre.

The mid-twelfth century (c. 1150) marks the birth of romance, as Latin epic was recasted into French. ${ }^{45}$ The Roman de Thèbes, the Roman d'Enéas, and Benoît de SainteMaure's Roman de Troie were free translations of classical works circulating at the Angevin royal court of Henry II and Eleanor of Aquitaine in England and at elite courts in northern France. These imaginative retellings introduced some distincitive narratological features: detailed descriptions of marvellous elements despite a (pseudo-)historical setting, lengthy portraits of heroes and heroines, and elaborate monologues that explore the emotional states of characters in depth. ${ }^{46}$

Writing within this vogue for works en romanz, Chrétien places human psychology and emotion front and centre in his stories. Turning Arthur, the warrior-monarch in the tradition of Geoffrey of Monmouth and Wace, into a dormant character, his romances introduce a new type of hero: the chevalier errant (knight errant). ${ }^{47}$ This new champion does

\footnotetext{
${ }^{45}$ This new literary form does not entirely start with Chrétien. Roman derives from the expression metre en roman, which means 'to translate into the vernacular'. The word already appears in the prologue to Benoît de Sainte-Maure's Roman de Troie (c. 1165). Nevertheless, Chrétien de Troyes is, as noted by Douglas Kelly, 'surely the first author to give the word romanz, or romance (Cligès, 23; Charrette, 2), a generic sense and therefore to have invented a new fictional genre: Arthurian romance with its characteristic themes and motifs' ('Chrétien de Troyes', in The Arthur of the French: The Arthurian Legend in Medieval French and Occitan Literature, ed. Glyn S. Burgess and Karen Pratt, Cardiff: University of Wales Press, 2006, 135-85, at 135).

${ }^{46}$ See Roberta L. Krueger, 'Introduction', in The Cambridge Companion to Medieval Romance, ed. Roberta Krueger (Cambridge: Cambridge University Press, 2000), 1-12, at 2; and Krueger, 'Chrétien de Troyes and the Invention of Arthurian Courtly Fiction', in A Companion to Arthurian Literature, ed. Helen Fulton (Malden, MA/Oxford: Wiley-Blackwell, 2009), 160-74, at 162.

${ }^{47}$ Marie-Luce Chênerie, Le chevalier errant dans les romans arthuriens en vers des 12e et 13e siècles (Geneva: Droz, 1986).
} 
not only pursue battle and adventure, but is, most importantly, in search of romantic inspiration. Such a quest presents the knight with a test of the code of chivalry, characterised by the portrayal of refined conduct and held high by affective ethics such as virtue, honour and, most importantly, courtly love. Although Chrétien was not necessarily the first to foreground these new affective ethics and the focus on the self (as we will see in chapter one), his literary heritage has been the most lasting. His stories caused a geographical shift in—or rather expansion of - the popularity of Arthurian matter, from literary traditions already permeated by the matière de Bretagne to the 'fringes', those traditions left uninfluenced by the genre. ${ }^{48}$

Chrétien de Troyes composed five Arthurian romances that survive today: Erec et Enide, Cligès, Chevalier au lion (Yvain), Chevalier de la charrette (Lancelot), and Conte du Graal (Perceval). In addition to these five Arthurian romances, Chrétien is also generally considered the author of the non-Arthurian adventure romance entitled Guillaume d'Angleterre. Several other works have been linked to him: At least two chansons written in the style and manner of the troubadours and an adaptation of a tale in Ovid's Metamorphoses, named Philomena. ${ }^{49}$ The latter may be gathered from the prologue to Cligès. This prologue lists a number of works translated from Latin into the vernacular, believed to have come about early on in Chrétien's career. In addition to the Philomela story, the prologue refers to French versions of the Pelops story from the Metamorphoses, of Ovid's Ars amatoria (Art of Love) and his Remedia Amoris (Remedy for Love), and mentions a work entitled 'Dou roi Marc et d'Yseut la blonde' (About King Marc and Yseat the blonde) (Cligès, 5). Except for

\footnotetext{
${ }^{48}$ For a discussion of Arthurian literature within its pan-European dimensions, including what has since been labelled as the 'fringes', see Bart Besamusca and Jessica Quinlan, 'The Fringes of Arthurian Fiction', Arthurian Literature 29 (2012), 192-242.

${ }^{49}$ Kelly, 'Chrétien de Troyes', 135.
} 
Philomena, none of these named works survive today. ${ }^{50}$

The five Arthurian romances ascribed to Chrétien seemingly enjoyed huge popularity almost immediately following their composition, both within and beyond the French-speaking domains. His stories were copied and imitated throughout the thirteenth century, leading to a vast expansion of his matière, as authors built on the stories' main characters, setting and subject matter through reworkings. In particular, Chevalier de la charrette and Conte $d u$ Graal served as sources of inspiration in the Francophone area as they were used extensively in the Arthurian prose cycles. Beyond this area, Chrétien's stories were introduced to foreign reading communities mainly through direct translation. German, Dutch, Norse-Icelandic, Swedish and English renditions of his romances circulated from the early thirteenth until the fourteenth century, some of which were copied well into the seventeenth century. Unlike the French favouring of Chrétien's Lancelot, non-French interest was chiefly focused on Erec, Yvain and Perceval, of which the middle one appears to have been the most popular. ${ }^{51}$

\section{Yvain}

Following two romances (Erec et Enide, Cligès) and preceding two (Lancelot, Perceval), Le chevalier ou lion or Yvain is the central piece in Chrétien's literary career on the Knights of

\footnotetext{
${ }^{50}$ Ibid. 135-36.

${ }^{51}$ On the influence and circulation of Chrétien's romances, see Michelle Szkilnik, 'Medieval Translations and Adaptations of Chrétien's Works', in A Companion to Chrétien de Troyes, ed. Norris Lacy and Joan Tasker Grimbert (Cambridge: D.S. Brewer, 2005), 202-13; and in the same volume Emmanuèle Baumgartner, 'Chrétien's Medieval Influence', 215-27. While Yvain is often labelled as the most popular of Chrétien's romances - a conclusion based on the the number of different European versions of these three romances and the number of manuscript copies in which they have come down to us today-it is important to keep in mind that other translated and/or adapted versions of these romances may well have existed, although they have not been preserved.
} 
the Round Table. ${ }^{52}$ The poem was composed sometime between 1170 and $1190 .^{53}$ Its octosyllabic couplets and many narratorial intrusions suggest that the story was to be read aloud, or possibly performed, in a court setting. ${ }^{54}$ Chrétien's prologues refer to such high courts, where professional storytellers may have performed. ${ }^{55}$ His works certainly reflect the aspirations, values and ideals of courtly society. In addition to oral recitation in a public setting, a scene in Yvain itself, in which a maiden reads aloud a romance to her parents (5358$68)$, testifies to the convention of oral recitation in a private setting. We lack further documentary evidence to be able to know exactly how his romances were presented to such audiences. However, studies on manuscript production have over the years been able to provide us with some clues regarding recitation practices, through the examination of layout and illustration, punctuation and other special marks, and written features, like versification and syntax. ${ }^{56}$

\footnotetext{
${ }^{52}$ This is the generally accepted order of composition for Chrétien's romances, although the precise chronology remains debated. See for instance Krueger, 'Chrétien de Troyes and the Invention of Arthurian Courtly Fiction', $160-74$.

${ }^{53}$ The general tendency is to place the composition of the poem around 1170. Studies in support of this date are: Anthime Fourrier, 'Encore la chronologie des oeuvres de Chrétien de Troyes', Bulletin bibliographique de la Sociéte internationale Arthurienne 2 (1950), 69-88; and Jean Frappier, Étude sur Yvain ou le chevalier au lion de Chrétien de Troyes (Paris: Sedes, 1969). Tony Hunt's 'Redating Chrestien de Troyes' in Bulletin bibliographique de la Sociéte internationale Arthurienne 30 (1978), 209-37, however, argues for the date of composition to be in the $1180 \mathrm{~s}$, while Douglas Kelly believes that the dating can be no more specific than between 1160 and 1190 ('Chrétien de Troyes'). In his early 1900s edition, Wendelin Foerster placed the composition of the poem between 1164 and 1173 (Kristian von Troyes: Yvain (Der Löwenritter), Halle: Verlag von Max Niemeyer, 1902, ix).

${ }^{54}$ See for example Evelyn Birge Vitz, Orality and Performance in Early French Romance (Woodbridge: Brewer, 1999), at 86-227; Douglas Kelly, 'Narrative Poetics: Rhetoric, Orality and Performance', in $A$ Companion to Chrétien de Troyes, 52-63.

${ }^{55}$ Kelly, 'Chrétien de Troyes', 162.

${ }^{56}$ See for instance Keith Busby, Terry Nixon, Alison Stones and Lori Walters, Les manuscrits de Chrétien de Troyes/The Manuscripts of Chrétien de Troyes, 2 vols (Amsterdam/Atlanta, GA: Rodopi, 1993); Malcolm B. Parkes, Pause and Effect: An Introduction to the History of Punctuation in the West (Berkeley: University of
} 
The story of Yvain has been preserved in fourteen manuscripts, fragments and excerpts, of which nine copies are more or less complete. ${ }^{57}$ It generally appears in two basic contexts. Firstly, Yvain appears in sizeable, court-produced romance collections from the early thirteenth century that are either genre or author organised. The first is Paris, Bibliothèque Nationale, fr. 794, the so-called Guiot manuscript, named after the scribe who signed the copy at the end of Yvain. ${ }^{58}$ The edition used in this dissertation has the Guiot manuscript as the basis for the text and translation. The second is Paris, Bibliothèque Nationale, fr. 1450, of unknown origin. The third is Chantilly, Musée Condé 472, which dates slightly later than the other two (middle of the thirteenth century) and is attributed to northeastern France. ${ }^{59}$ All three manuscripts are thematically organised and place Chrétien's romances alongside other Arthurian material. Similar in organisation and in format, a group of fragments survives that are presumed to be the remains of a comparable large-sized manuscript, now lost to us. These are the Annonay fragments (private collection). They bear witness to a manuscript that contained at least four of Chrétien's romances, including Yvain, that was likely to be author-based. These fragments are dated to the first half of the thirteenth century and, like the Guiot-copy, have been assigned a Champenois origin.

Additionally, the story of Yvain often appears paired with that of Lancelot, perhaps

California Press, 1992); and Mario Roques for the Guiot manuscript ('Le scribe Guiot et le manuscrit français 794 de la Bibliothèque Nationale', Comptes rendus. Académie des Inscriptions et Belles Lettres 1 (1952), 21-22. ${ }^{57}$ For a description of these manuscripts see Pierre Jonin, Prolégomènes à une edition d'Yvain, Publications des annals de la Faculté des Lettres, Aix-en-Provence 19 (Gap: Editions Ophrys, 1958); Alexandre Micha, La tradition manuscrite des romans de Chrétien de Troyes (Geneva: Droz, 1939); Keith Busby, et al., Les manuscrits de Chrétien de Troyes, vol. 1, 17-25.

${ }^{58}$ The colophon states that the copy was written by Guiot, "who can be found in front of the church of Notre Dame del Val'. This information places the scribe's activities at Provins. The church in Provins has strong ties to Countess Marie de Champagne, which has been taken as evidence that the Guiot manuscript was made for the court of Champagne (Busby, et al., Les manuscrits de Chrétien de Troyes, vol. 1, 21-22).

${ }^{59}$ For a more complete description of its contents, see Busby, 'The Manuscripts of Chrétien's Romances', in $A$ Companion to Chrétien de Troyes, 64-75, at 66-67. 
due to their parallel narrative action. ${ }^{60}$ This is the case for fr. 12560 , for Vatican City, Reg. Lat. 1725 and Princeton, Univerity Library, Garrett 125. The partly incomplete, late thirteenth-century Garrett copy is illustrated. The part that remains of Yvain contains seven miniatures. ${ }^{61}$ With its nine minatures, six of which are multi-compartment, is Paris, Bibliothèque Nationale, fr. 1433 the most elaborately illustrated copy of Yvain. Both copies depict the classic scenes from the text and offer a kind of visual punctuation. ${ }^{62}$

Unfortunately, no manuscripts survive from Chrétien's lifetime. There is no doubt, however, that Chrétien wrote Yvain. His name is inscribed prominently in the epilogue: 'Del chevalier al lion fine/ Crestïens son romant issi' (6824-25) (Thus Chrétien brings to a close/ his romance of the Knight with the Lion). The identity of this 'Crestiens' is, however, less clear. We do not know who exactly is behind this signature. In all five romances, the author refers to himself as 'Crestiens' and only in one occasion by the full name 'Crestiens de Troies' (prologue to Erec, 9). ${ }^{63}$ The latter suggests that the author was native to Troyes, a city in the province of Champagne. This notion seems to be confirmed by his association with the court of Marie de Champagne, wife of Count Henry I of Champagne (Henry the Liberal) and daughter of Eleanor of Aquitaine by her first husband, King Louis VII of France. Evidence for the linking of Chrétien with the court of Champagne is given in Lancelot where the poet himself states that he writes at the behest of Marie de Champagne who provided the matière (subject matter) and san (orientation or the treatment of the matter) for the poem (Charrette, $1-3,21-7)$.

Chrétien later mentioned Philippe de Flandre as patron, under whose commission he

\footnotetext{
${ }^{60}$ Busby, 'The Manuscripts of Chrétien's Romances', 69.

${ }^{61}$ For a detailed discussion of Garrett 125, see Robert L. McGrath, 'A Newly Discovered Illustrated Manuscript of Chrétien de Troyes's Yvain and Lancelot in the Princeton University Library', Speculum 38 (1963), 583-94. The codex survives in a fragmentary state and preserves a little over ninety percent of Yvain.

${ }^{62}$ Busby, 'The Manuscripts of Chrétien's Romances', 72.

${ }^{63}$ Ibid. 136.
} 
wrote Perceval ou le conte du Graal. ${ }^{64}$ Their connection is less clear. After Henry de Champagne's death in 1181, the Count of Flanders briefly courted his widow Marie - a period to which Chrétien's dedication of his Perceval perhaps belongs. ${ }^{65}$ Philippe's death in the Third Crusade in 1191 may well explain the romance's unfinished state. It was either this loss of patronage or the death of Chrétien himself - as claimed by one of the Perceval continuators Gerbert de Montreuil around 1230 — that left Perceval uncompleted. ${ }^{66}$

Sarah Kay, however, cautions against identifying Chrétien de Troyes as a historical figure: 'While historical documents provide a couple of examples of figures named Christianus from the Troyes region in the later twelfth century, we cannot know whether they can be identified with the author we call Chrétien de Troyes' ${ }^{67}$ She points out how our current-day conception of who Chrétien was and what he wrote is not exclusively based on historical records, but arises from a kind of shuffle between available names and texts. The poet's social status remains uncertain and the author has been varyingly characterised as an ecclesiastic, a low-level cleric, a courtier, a trouvère, a minstrel or jongleur. ${ }^{68}$ Some scholars have linked Chrétien to the prominent troubadours of his time, Rigaut de Barbezilh and Bernart de Ventadorn, who were known to work at the court of Eleanor of Aquitaine, and

\footnotetext{
${ }^{64}$ Jean Marie Fritz's 'Chrétien de Troyes' presents a comprehensive introduction to the poet's life and work, see Dictionnaire des lettres françaises: Le Moyen Âge, ed. Robert Bossuat et al. (Paris: Fayard, 1964), 266-80. For more information on Chrétien's patrononage under Marie de Champagne and Philippe de Flandre see June Hall McCash, 'Chrétien's Patrons', in A Companion to Chrétien de Troyes, 15-25; and John F. Benton, 'The Court of Champagne as a Literary Centre', Speculum 36 (1961), 551-91.

${ }^{65}$ Ad Putter, 'The Twelfth-Century Arthur', in The Cambridge Companion to the Arthurian Legend, ed. Elizabeth Archibald and Ad Putter (Cambridge/New York: Cambridge University Press, 2009), 36-52, at 44.

${ }^{66}$ See for example Bart Besamusca, 'Readership and Audience', in Handbook of Arthurian Romance, ed. Leah Tether and Johnny McFadyen (Berlin: De Gruyter, 2017), 117-32, at 120.

67 'Who was Chrétien de Troyes?', in Arthurian Literature, ed. James P. Carley and Felicity Riddy, vol. 15 (Cambridge: D.S. Brewer, 1997), 1-36, at 2. For a critical discussion of Chrétien's 'historicity', see moreover the introduction to Zrinka Stahuljak et al, Thinking Through Chrétien de Troyes, Gallica 19 (Cambridge: D.S. Brewer, 2011), especially 2, 10.

${ }^{68}$ See Kelly, 'Chrétien de Troyes', 137.
} 
have argued for his sojourn in Britain at the Plantagenet court. ${ }^{69}$

\section{Iwein}

The first to adapt Chrétien's matière for a non-French audience was the Swabian knight Hartmann von Aue. He brought two of Chrétien's stories to a German-speaking audience, starting with Erec et Enide. ${ }^{70} \mathrm{He}$ is believed to have composed his Erec around 1180-90, which means he was writing no more than twenty years after Chrétien presumably composed his story. The second romance translated by Hartmann is Iwein, der Ritter mit dem Löwen. Together with Erec, it is transmitted in the Ambraser Heldenbuch (Österreichische Nationalbibliothek, Cod. Ser. nova 2663). Unlike Erec, which survives in only one complete manuscript and in a few fragments, Iwein has a rich manuscript tradition. Remains of as many as thirty-two copies (sixteen complete manuscripts and seventeen fragments) have come down to us, attesting to the story's popularity throughout the Middle Ages. Of these thirtytwo, MS A (Heidelberg, Universitätsbibliothek, cpg 397) and MS B (Gießen, Universitätsbibliothek, Nr. 97) are said to be the earliest complete redactions and have been found to be of the most textual significance. ${ }^{71}$ Both are ascribed to the beginning of the second quarter of the thirteenth century. Chapter two of this study discusses these two

\footnotetext{
${ }^{69}$ See Luciano Rossi, 'Chrétien de Troyes e i trovatori: Tristan, Linhaura, Carestia', Vox Romanica 46 (1987), 26-62; Carleton W. Carroll, 'Quelques observations sur les reflets de la cour d'Henri II dans l'oeuvre de Chrétien de Troyes', Cahiers de Civilisation Médiévale 37 (1994), 33-39.

${ }^{70}$ The 2002-discovery of fragments of another Erec, the Zwettl fragments, that may predate Hartmann von Aue's Erec, have somewhat complicated the view of Hartmann as the first German adapter of Arthurian Romance, see Kurt Gärtner, 'Die Zwettler Erec-Fragmente: Versuch einer ersten Auswertung', in Literatur als Erinnerung, Winfred Woesler zum 65. Geburtstag, ed. Bodo Plachta (Tübingen: Niemeyer, 2004), 35-50.

${ }^{71}$ Both served as base manuscripts for Karl Lachmann and Georg F. Benecke's edition (Iwein: Der Riter mit dem Lewen, getihtet von den Hern Hartman Dienstman ze Ouwe, Berlin: G. Reimer, 1827, revised in 1877). The edition by Cyril Edwards renders both redactions and indicates where B deviates from A (Hartmann von Aue, Iwein, German Romance, ed. and trans. Cyril Edwards, vol. 3, Arthurian Archives 16, Cambridge: D.S. Brewer, 2007).
} 
manuscripts in more detail.

Like Erec, Iwein was composed following fairly closely on the heels of Chrétien's source, around 1204. This Middle High German version of Chrétien's story considerably exceeds its original in length, although its episodic adaptation is more faithful to the Old French than that of Erec, which contains even longer expansions. ${ }^{72}$ Despite these expansions, scholars agree that Hartmann in both cases was translating directly from the French stories. One of the Wolffenbüttel fragments of Erec provides evidence in support of this: 'alse uns Chrestiens saget' (as Chrétien tells us, 4629). ${ }^{73}$

Scholars have been unable to locate references to Hartmann von Aue in historical records. Any information on the poet comes from what he himself tells us in his works or what other poets have written about him, among them Heinrich von dem Türlin, Wolfram von Eschenbach, and Gottfried von Straßburg. ${ }^{74}$ We know from their accounts that Hartmann lived in the duchy of Swabia, one of the five duchies of the medieval German Empire. Specifically the southwestern part of Swabia, belonging to the Alemannic dialect area in the Southwest of present-day Germany, is the area in which Hartmann was most likely active. ${ }^{75}$ The many references to his works by contemporaries as well as later poets attest to Hartmann's role in bringing Arthurian romance to German-speaking areas. Scholars have found his influence on the development of the genre in the Middle High German literary

\footnotetext{
${ }^{72}$ For Erec this is a difference of about 3240 lines. For Iwein, the expansion runs no longer than approximately 1200 lines.

${ }^{73}$ See the introduction to Iwein, ed. and trans. Edwards, xiv.

${ }^{74}$ For biographical information on Hartmann von Aue, see Francis G. Gentry, ed., A Companion to the Works of Hartmann von Aue (Rochester, NY: Boydell \& Brewer/Camden House, 2005); Timothy McFarland and Silvia Ranawake, eds., Hartmann von Aue: Changing Perspectives, London Hartmann Symposium 1985 (Göppingen: Kümmerle, 1988); Elfriede Neubuhr, Bibliographie zu Hartmann von Aue (Berlin: Schmidt, 1977).

${ }^{75}$ Francis G. Gentry, 'Introduction', in A Companion to the Works of Hartmann von Aue, 1-8, at 6.
} 
tradition to be profound. ${ }^{76}$

In addition to Iwein and Erec, he is named as the author of two religious-didactic works, Der arme Heinrich and Gregorius, and of Büchlein, a treatise on courtly love, which he presumably wrote as a youth. ${ }^{77}$ From his own prologues to Iwein and Der arme Heinrich, we are further to believe that Hartmann was a 'dienstmann' (servitor) and a 'rîter' (a knight). In the introduction to his English translation of Iwein, Patrick M. McConeghy offers a more extensive discussion of these indentifiers:

As a dienstmann, he [Hartmann] thus belonged to a group of lesser courtly officials (in Latin: ministeriales) who by the beginning of the thirteenth century were growing in influence and prestige. These once-unfree knights and officials were rewarded for their service to the court with the customary room and board, but also with inheritable positions or even with a small estate over which they could exercise limited authority. ... As a member of this group, Hartmann would have enjoyed security, position, prestige, and a comfortable life. Hartmann also identifies himself as a knight, a ritter. Originally the term ritter referred to one in service of the landed nobility or merely to a common fighter not in the immediate household of the lord. By 1200 the designation had gained in stature and had taken on social and moral implications. Like his French counterpart the chevalier, the German ritter led a high courtly life and had as much to do with refined behavior, elegant clothing, noble attitudes, and handsome appearance

\footnotetext{
${ }^{76}$ For an overview see Günther Schweikle, ed., Dichter über Dichter im mittelhochdeutscher Literatur, Deutsche Texte 12 (Tübingen: Niemeyer, 1970); and the introduction to Iwein, ed. and trans. Edwards, xv-xviii.

${ }^{77}$ For Der arme Heinrich and Gregorius, see Brian Murdoch, 'Hartmann's Legends and the Bible', in $A$ Companion to the Works of Hartmann von Aue, 141-60, and in the same volume, Scott E. Pincikowski, 'The Body in Pain in the Works of Hartmann von Aue', 105-24.
} 
as with aptitude for sword and shield. ${ }^{78}$

In addition to numerous songs of courtly love, Hartmann wrote crusading songs. ${ }^{79}$ The latter contain evidence that the poet may have taken part in the Third Crusade in $1188 .{ }^{80}$

The cultivation of Chrétien's stories in the German literary tradition was conceivably due to the presence of noble families who commissioned courtly literature. Unlike Chrétien's works, Hartmann's romances contain no reference or dedication to a patron or political sovereign. Manfred Scholz suggests that Hartmann wrote in patronage of one of the dukes of Zähringen, although there is still little evidence to support this. ${ }^{81}$ Will Hasty points towards the imperial Hohenstaufen family, whose reign designated a time of cultural blossoming. ${ }^{82}$ At the time of writing of Hartmann von Aue, the German Empire was under the rule of Frederick II ('Barbarossa', 1194-1250). Despite all appearances of a unified kingdom, Frederick's rule and that of his successor is characterised by wars against rebellious princes in an effort to maintain power. In exchange for their loyalty and support, feudal princes and local lords were granted numerous rights and grew more powerful. ${ }^{83}$ Within this position it is easily imaginable, Hasty notes, that these nobles found a fascination with the world of Arthur, an image that may have reflected their newfound power. According to Hasty, '[i]t is arguably at this broader level of identification, rather than in any more specific propagandistic or political

\footnotetext{
${ }^{78}$ See the introduction to Hartmann von Aue: Iwein, ed. and trans. Patrick M. McConeghy, Garland Library of Medieval Literature 19A (New York/London: Garland Publishing, 1984), xiii. See, moreover Gentry, 'Introduction', 5-6.

${ }^{79}$ Will Hasty, 'Hartmann von Aue as Lyricist', in A Companion to the Works of Hartmann von Aue, 21-42.

${ }^{80}$ Iwein, ed. and trans. Edwards, xiii.

${ }^{81}$ Erec, ed. Manfred Günter Scholz, trans. Suzanne Held, Bibliothek des Mittelalters 5 (Frankfurt am Main: Deutscher Klassiker Verlag, 2004), 569-70.

82 'The Allure of Otherworlds: The Arthurian Romances in Germany', in A Companion to Arthurian Literature, ed. Helen Fulton (Oxford: Wiley-Blackwell, 2009), 176.

${ }^{83}$ As is described by Hasty, 'The Allure of Otherworlds', 175-88.
} 
use, that the German nobility engaged and developed narrative material. ${ }^{84}$ The fascination of German nobility with the Arthurian matter is, for example, attested by the Rodenegg castle frescoes in South Tyrol (see cover image). ${ }^{85}$ These murals, dating from 1200-1230, were commissioned by Arnold II of Rodank and depict scenes from the first part of Hartmann's Iwein. A similar cycle of murals is situated in Hessenhof in Schmalkalden. The surviving twenty-six scenes were presumably created between $1220-1230 .{ }^{86}$

Although Hartmann is generally named as the first adaptor of Chrétien's Yvain, ${ }^{87}$ it should be noted that the story of the Knight with the Lion may have already been circulating in the Low Countries at the time of Iwein's composition. As a bridging zone of France and the German Empire, the medieval 'Low Countries' covered a set of territories in the estuary of the rivers Scheldt, Meuse and Rhine. Although the political history of these lands is a complex one, the area is nowadays roughly taken to correspond to the territories of Belgium and the Netherlands — sometimes including the Grand Duchy of Luxemburg. ${ }^{88}$ Except for

\footnotetext{
${ }^{84}$ Hasty, 'The Allure of Otherworlds', 176, citing Harry Jackson and Silvia Ranawake, eds, The Arthur of the Germans: The Arthurian Legend in Medieval German and Dutch Literature (Cardiff: University of Wales Press, 2000), 4-5.

${ }^{85}$ See for example Michael Curschmann, 'Der aventiure bilde nemen: The Intellectual and Social Environment of the Iwein Murals at Rodenegg Castle', in Chrétien de Troyes and the German Middle Ages, ed. Martin Johnes and Roy Wisbey (Cambridge: D.S. Brewer, 1993), 219-27.

${ }^{86}$ Roland Möller, 'Untersuchungen an der Wandmalereien des Iwein-epos Hartmanns von Aue im Hessenhof in Schmalkalden', in Zur Kunst des 13. Jahrhunderts in Mitteldeutschland, ed. Hans-Joachim Krause, Festschrift für Ernst Schubert/Sachsen und Anhalt, Jarbuch der historischen Kommission für Sachsen-Anhalt 19 (Weimar, 1997), 389-453.

${ }^{87}$ The story was later adapted by the fifteenth-century Bavarian writer and painter Ulrich Füetrer as a direct reworking from Hartmann's Iwein. The second part of his Buch der Abenteuer (1473-1487) — a collection of tales recounting the adventures of various knights - tells the story of the knight Iban, see Bernd Bastert, Der Münchner Hof und Fuetrers Buch der Abenteuer: Literarische Kontinuität im Spätmittelalter, Mikrokosmos, Beiträge zur Literaturwissenschaft und Bedeutungsforschung 33 (Frankfurt am Main: Peter Lang, 1993). Joseph M. Sullivan is currently working on the first modern-language translation of Iban (forthcoming).

${ }^{88}$ Although the area was unified by its language, Middle Dutch, the medieval Low Countries is essentially a modern construct, as the lands did not become politically unified until the sixteenth century, see Bram Caers and
} 
Perceval, none of Chrétien's stories have come down in Middle Dutch. However, scholars have long suspected a far richer Dutch Arthurian literary tradition than the extant textual witnesses would indicate. ${ }^{89}$ Indeed, it seems that, in addition to the Perchevael, a Middle Dutch version of Yvain circulated at some point in time. In the volume The Arthur of the Low Countries, Bram Caers and Mike Kestemont proffer a booklist from Flanders attesting to such existence:

The 1417 book list of Jan VI van Gistel, chamberlain to the count and as such one of the most important noblemen in Flanders, contains not only a reference to Chrétien's Perceval in French, but also mentions a listing which may be interpreted as a now lost) translation of Chrétien's Le Chevalier au Lion, reading as follows: een dietsch bouc sprekende van ystorien van Ingeland ende van den ruddere metten leeuwe ende andren (a Dutch book speaking of histories of England and of the Knight with the Lion and others). ${ }^{90}$

Unfortunately, the Dutch work alluded to has never been recovered.

\section{Ívens saga}

It is not until some fifty years later that the story of Yvain reached Scandinavia, when it was

Mike Kestemont, 'The Cultural and Historical Context of the Low Countries' in The Arthur of the Low Countries: The Arthurian Legend in Dutch and Flemish Literature, ed. Bart Besamusca and Frank Brandsma (Cardiff: University of Wales Press, 2021), 7-30, at 8-10.

${ }^{89}$ See the preface to Geert H.M. Claassens and David F. Johnson, eds, King Arthur in the Medieval Low Countries (Leuven: Leuven University Press, 2000), at vii -viii, and in the same volume, Rita Schlusemann, 'The Late-Medieval German Reception of Dutch Arthurian Literature in Heidelberg and Blankenheim', 97-111.

${ }^{90}$ Caers and Kestemont, 'The Cultural and Historical Context of the Low Countries', 18. See also Caers, 'Een buchelin inn flemische: Over ontstaan en verspreiding van de ridderepiek in de Nederlanden (ca. 1150-1450)', Tijdschrift voor Nederlandse Taal- en Letterkunde 127.3 (2011), 223-51, at 240. 
translated at the Norwegian court of Hákon Hákonarson (1204-63). ${ }^{91}$ King Hákon the Old, as he is also referred to in order to distinguish him from his eponymous son, is believed to have commissioned the translation of a collection of French courtly literature, now known as the riddarasögur, as part of an introduction programme of courtly romance into Scandinavian literature. $^{92}$ This corpus included important Old French and Anglo-Norman works such as Thomas's Tristan and Marie de France's Lais, as well as three of Chrétien's romances, Yvain, Erec et Enide and Perceval, translated around the middle of the thirteenth century as Ívens saga, Erex saga and Parcevals saga (together with Valvens páttr). ${ }^{93}$

The reason behind this surge in translation activities has been debated. Henry Goddard Leach and Geraldine Barnes have argued that these translations present didactic models of

\footnotetext{
${ }^{91}$ There is non-textual evidence that suggest that the material related to the story of the Knight with the Lion may have passed to Scandinavia much earlier than previously thought. Rikhardsdottir has noted the existence of carved images on a wooden church door in Valpjófsstaðir in the East of Iceland that may depict scenes from the story, as we know it from both the Welsh tradition and from Chrétien's romance. As the door is presumed to have been carved around 1200, this would predate the translation of the story at the court of King Hákon by at least a few decades (Emotion in Old Norse Literature, 32; see the cover of Rikhardsdottir, Medieval Translations and Discourse for an image of the door; see Kristján Eldjárn, Hundrað ár i Djóðminjasafni (Reykjavík: Mál og menning, 1994) for a full description). The door is currently preserved in the National Museum of Iceland.

${ }^{92}$ As a term riddarasögur indicates those sagas 'which are neither of kings nor of saints nor of Icelanders', but of 'knights', as is, for example, clarified by Geraldine Barnes in 'The Riddarasögur and Mediæval European Literature', Mediaeval Scandinavia 8 (1975), 141-58, at 141. The term denotes both Norse translations of French, Anglo-Norman and Latin narratives of different genres, as well as later Icelandic chivalric works in a similar style. For an overview of both translated and indigenous riddarasögur and their differences, see moreover Sif Rikhardsdottir and Stefka G. Eriksen, 'État present: Arthurian Literature in the North', Journal of the International Arthurian Society 1.1 (2013), 3-28; Marianne E. Kalinke, King Arthur, North-by-Northwest: The 'matière de Bretagne' in Old Norse-Icelandic Romances, Bibliotheca Arnamagnæana 37 (Copenhagen: C.A. Reitzels Boghandel, 1981).

${ }^{93}$ Of these three translations only Ívens saga specifically testifies of King Hákon's patronage. Its concluding sentence reads: 'Ok lykr hér sögu herra Íven er Hákon kóngr gamli lét snúa ór franzeisu í norrænu' (And the saga of Sir Íven ends here, which King Hákon the Old had ordered translated from French into Norse). See Ívens saga, ed. and trans. Marianne E. Kalinke, in Norse Romance, ed. Marianne E. Kalinke, vol. 2: The Knights of the Round Table, Arthurian Archives 4 (Cambridge: D.S. Brewer, 1999), 33-102, p. 98.
} 
behaviour that were to instruct the Nordic audiences in the customs of chivalry. ${ }^{94}$ Marianne E. Kalinke, conversely, has emphasised their entertaining function within the Norse reading communities and points out that those elements that are quintessentially chivalric have either been reduced or omitted in translation. ${ }^{95}$ Recent scholarship has moved past this polarised debate and has shown that education and entertainment need not be mutually exclusive in the adaptation of these stories at King Hákon's court. It has, for example, been argued that the translations were products of a more general cultural programme of King Hákon that in addition to other literary activities, such as the composition of the educational text Konungs skuggsjá (The King's Mirror), included architectural initiatives, such as the building of Hákon's hall in Bergen. ${ }^{96}$ Such undertakings may not only have contributed to both the education and entertainment of the Norwegian court, but may also have legitimised its positioning in relation to other European courts.

The Norwegian translations of Chrétien's romances render their sources quite closely,

\footnotetext{
${ }^{94}$ See Henry Goddard Leach, Angevin Britain and Scandinavia, Harvard Studies in Comparative Literature 6 (Cambridge, MA, 1921), 153; Geraldine Barnes, 'The "Discourse of Counsel” and "Translated” Riddarasögur', in Learning and Understanding in the Old Norse World: Essays in Honour of Margaret Clunies Ross, ed. Judy Quinn, Kate Heslop and Tarrin Wills (Turnhout: Brepols, 2007), 375-97.

${ }^{95}$ Kalinke, King Arthur, North-by-Northwest, 28. For a summary of this polarised debate see Larrington, 'The Translated Lais', in The Arthur of the North: The Arthurian Legend in the Norse and Rus' Realms, ed. Marianne E. Kalinke (Cardiff: University of Wales Press, 2011), 77-97, at 93-94; Barnes, 'Some Current Issues in Riddarasögur Research', Arkiv för nordisk filologi 104 (1989), 73-88.

${ }^{96}$ Bjarne Fidjestøl, 'Romantic Reading at the Court of Håkon Håkonsson', in Selected Papers, ed. Odd Einar Haugen and Else Mundal, trans. Peter Foote (Odense: Odense University Press, 1997), 351-65, at 360. See also Liliane Irlenbusch-Reynard, 'Translations at the Court of Hákon Hákonarson: A Well Planned and Highly Selective Programme' Scandinavian Journal of History 36.4 (2011), 387-405; Vincent Almazan, 'Translations at the Castilian and Norwegian Courts in the Thirteenth Century: Parallels and Patterns', Medieval Scandinavia, 12 (1988), 213-32.
} 
except for two main deviations. ${ }^{97}$ Although retaining the overall structure and content of their sources, all three translations condense their source material. They tend to abbreviate or completely omit passages, especially those containing direct speech as well as detailed digressions, such as long descriptions, psychological analyses and/or authorial commentary, in favour of foregrounding event and action. ${ }^{98}$ What is more, unlike the other rewritings discussed here, the Norse translations are rendered in prose. Katharina Seidel points out that this prose form most likely came about in the process of adapting the story to the native 'saga style' with which the Norwegian audience was more familiar, but also notes that the favouring of the prose form is in line with a broader European trend of rendering Arthurian stories into prose that started in the thirteenth century, mainly observed in the French and Italian tradition. ${ }^{99}$ The 'courtly style' applied in these prose translations is not completely devoid of poetic elements, however, and differs considerably from the native 'saga style'. ${ }^{100}$ It is characterised by stylistic features such as rhymed proverbs and puns, as well as alliteration and/or synonymous or antithetical pairs for rhetorical affect. ${ }^{101}$ Parcevals saga even shows

\footnotetext{
${ }^{97}$ For a discussion of form and style of these three translated romances see Katharina Seidel, Textvarianz und Textstabilität: Studien zur Transmission der Ívens saga, Erex saga und Parcevals saga, Beiträge zur nordischen Philologie 56 (Tübingen: A. Francke Verlag, 2014), 45-55.

${ }^{98}$ Hanna Steinunn Porleifsdóttir reveals this reduction to be around sixty percent for Ívens saga, ('Dialogue in the Icelandic Copies of Ívens saga', in Übersetzen im skandinavischen Mittelalter, ed. Vera Johanterwage and Stefanie Würth, Vienna: Verlag Fassbaender, 2007, 167-76), at 167. Claudia Bornholdt believes the reduction to be most extensive for Erex saga ('The Old Norse-Icelandic Transmission of Chrétien de Troyes's Romances: Ívens saga, Erex saga, Parcevals saga with Valvens páttr', in The Arthur of the North, 100.)

${ }^{99}$ Seidel, Textvarianz und Textstabilität, 45-46.

100 The courtly style has also been assigned to other works translated at King Hákon's court, such as the Old Norse translations of the chansons de geste, see Jonna Kjær, 'La reception scandinave de la littérature courtoise et l'exemple de la Chanson de Roland/Af Rúnzivals bardaga: Une epopée féodale transformée en roman courtois?', Romania 114 (1996), 50-69.

${ }^{101}$ Rikhardsdottir and Eriksen, 'État present', 14. For information on this 'courtly style' see Kalinke, 'Sources, Translations, Redactions, Manuscript Transmission', in The Arthur of the North, 41; Kalinke, 'Alliteration in Ívens saga', Modern Language Review 74 (1979), 871-83.
} 
instances of end rhyme that may have been based on Chrétien's verses. ${ }^{102}$

While the translations remain anonymous, correspondences in lexicon and syntacticstylistic features between these works have led to suggestions of a common authorship, in particular for Ívens saga and Parcevals saga/Valvens páttr. ${ }^{103}$ Some scholars ascribe this authorship to (the milieu of) Brother Robert, who is named in Tristrams saga as its supposed translator and who is believed to be one and the same person as Abbot Robert, named as the translator for Elis saga ok Rósamundu (deriving from the chanson de geste Elie de St Gille). ${ }^{104}$ Although none of the Norse translations of Chrétien's romances contain any textual evidence regarding their authorship, Claudia Bornholdt notes:

While it is difficult to prove with certainty, there can be little doubt that the translation [here referring to Parcevals saga] was completed either by Brother Robert himself or by translators working with or shortly after him at the Norwegian court. The language, syntax and style of Parcevals saga and Valvens páttr clearly indicate that the

\footnotetext{
${ }^{102}$ For a discussion of rhymed couplets and examples of end rhyme in Parcevals saga, see Bornholdt, 'The Old Norse-Icelandic Transmission of Chrétien de Troyes's Romance', 102-3.

${ }^{103}$ Similarities with the other translations of courtly French literature at Hákon's court have led some scholars to group these works together with Tristrams saga, Möttuls saga and the Strengleikar in the so-called 'Tristramgroup' of the riddarasögur, although Erex saga is generally not tied to this group, see Paul Schach, 'Some Observations on the Translations of Brother Robert', in Les relations littéraires franco-scandinaves au Moyen Âge, Actes du Colloque de Liège (Paris: Les Belles Lettres, 1975), 117-35; Peter Hallberg, 'Norröna riddarsagor: Några språkdrag', Arkiv för nordisk filologi 86 (1971), 114-37; Hallberg, 'Broder Robert, Tristrams saga och Duggals leizla: Anteckningar till norska översättningar', Arkiv för nordisk filologi 88 (1973) 55-71; Kalinke, King Arthur, North-by-Northwest, 131-77.

${ }^{104}$ See Tristrams saga ok Ísöndar, ed. and trans. Peter Jørgensen, in Norse Romance, ed. Marianne E. Kalinke, vol. 1: The Tristan Legend, Arthurian Archives 3 (Cambridge: D.S. Brewer, 1999), 23-226, at 28; Elis saga ok Rósamundu, ed. Eugen Kölbing (Heilbronn: Verlag von Gebr. Henninger, 1881), 116. Both citations also refer to King Hákon and thereby bring Brother Robert in connection with Hákon's court, see Stefka Eriksen, Writing and Reading in Medieval Manuscript Culture: The Translation and Transmission of the Story of Elye in Old French and Old Norse Literary Contexts (Turnhout: Brepols, 2014), 101-7.
} 
translator was a Norwegian who worked in the same environment as the translator(s) of Tristrams saga, Möttuls saga and Ívens saga. ${ }^{105}$

King Hákon's reign is known as one of peace and stability. He was able to unite the kingdom of Norway after a long period of recurring territorial battles and civil discords. ${ }^{106}$ This union allowed for diplomatic contact and mercantile exchange with foreign courts, particularly between Norway and England. The friendly relationship that developed from this exchange between King Hákon and the young ruler of England, King Henry III (1216-72), has led scholars to suggest that the manuscripts containing the French and Anglo-Norman materials may have come to Norway via England, perhaps as part of a royal exchange of gifts, which were subsequently assigned by Hákon to be translated at his court. ${ }^{107}$ After all, although composed in France, the collection of French courtly literature that was to be imported was originally patronised by the Angevin royal family, making it very plausible that these texts also circulated at the English court at that time and were just as much seen as representatives of it, as has been pointed out by Sif Rikhardsdottir. ${ }^{108}$

Not only were King Hákon's cultural ambitions of great influence on the

\footnotetext{
${ }^{105}$ Bornholdt, 'The Old Norse-Icelandic Transmission of Chrétien de Troyes's Romance', 101-2.

${ }^{106}$ After the reign of Canute, who ruled over England, Denmark and Norway, his descendents entered into a period of political unrest. For a more elaborate historical description of this period of political unrest see Knut Helle, ed., The Cambridge History of Scandinavia (Cambridge: Cambridge University Press, 2003), especially 369-91. See also Leach's Angevin Britain and Scandinavia.

${ }^{107}$ See for instance Seidel, Textvarianz und Textstabilität, 44. For more information on the relations between the Norwegian and the English court see Knut Helle, 'Anglo-Norwegian Relations in the Reign of Håkon Håkonsson (1217-63)', Medieval Scandinavia 1 (1968), 101-14.

${ }^{108}$ Medieval Translations and Cultural Discourse: The Movement of Texts in England, France and Scandinavia (Cambridge: D.S. Brewer, 2012), 18. After her first marriage to Louis VII of France was annulled, Eleanor of Aquitaine entered into a second marriage with Henry II of England or Henry Plantagenet, thus repositioning from the French to the English royal court. Eleanor's daughter, Marie de Champagne, served as a patron for Chrétien de Troyes, as we know from his Lancelot.
} 
dissemination of courtly romance in Norway, the importation of French material furthermore sparked the adaptation of Chrétien's material in Iceland as well as Sweden, and later in Denmark. ${ }^{109}$ Kalinke rightly points out that 'while the main conduit of Chrétien's romances to the North in the Middle Ages was Norway, their preservation was in the hands of Icelandic scribes', who were copying and transforming the translated texts well into the seventeenth century. ${ }^{110}$ Since Ívens saga, Parcevals saga and Erex saga have all solely been preserved in fifteenth to seventeenth century Icelandic manuscripts, scholars now generally speak of Old Norse-Icelandic renditions when discussing these works. This ensures the inclusion of the possible effect of scribal influences as well as reception-generated changes aimed at later Icelandic reading communities when interpreting these translated texts. ${ }^{111}$

The degree to which these Icelandic redactions agree with or differ from the original Norse translations is debated. While Kalinke points out the variation in scribal practices - that may in some cases have led to substantial revisions like the omissions and abbreviations we find in many of the riddarasögur - Barnes shows such modifications to reveal a distinct pattern in the way the Norwegian translators adapted their French examples. ${ }^{112}$ In 'The Riddarasögur: A Medieval Exercise in Translation', Barnes analyses and compares the style and manner of translation in some of the riddarasögur texts that have been preserved in both Icelandic and Norwegian manuscripts, concluding that it seems safe to assume that in their

\footnotetext{
${ }^{109}$ King Hákon's reputation as a well-educated man and a benefactor of literature was already recognised by his contemporaries. Matthew Paris of St Albans, for instance, refers to him as 'bene litteratus' in his Rerum Britannicarum Medii AEvi Scriptores 57, see Kalinke, 'The Introduction of the Arthurian Legend in Scandinavia', in The Arthur of the North, 1-10, at 10.

${ }^{110}$ Ibid. 17.

${ }^{111}$ The oldest complete texts of both Ívens saga and Parcevals saga are dated around 1400. Erex saga survives only in paper copies from the seventeenth century and later.

${ }^{112}$ See for instance Marianne E. Kalinke, 'Scribes, Editors, and the Riddarasögur', Arkiv för nordisk filologi 97 (1982), 36-51; Kalinke, 'Sources, Translations, Redactions, Manuscript Transmission', 22-47; Barnes, 'Some Current Issues in Riddarasögur Research', 73-88.
} 
present state the riddarasögur manuscripts accurately represent the original Norse translations. ${ }^{113}$

In 'Some Current Issues in riddarasögur Research', Barnes likewise compares different redactions for Ívens saga. Since the scribal alterations she assigns are only of minor character, she concludes that the extant Icelandic manuscripts do seem to accurately represent the original translation of Yvain. ${ }^{114}$ Rikhardsdottir also ascribes the more 'radical narrative reconstructions' of the text to the Norwegian translator and expresses the belief that scribal interventions only served to 'accentuate the existing adjustments by further omissions or shifts in thematic emphasis'. ${ }^{115}$ What is more, she points out that it is safe to assume a general commonality in the material's transformation and reception owing to the close cultural connections between Norway and Iceland in the thirteenth century, especially when we take into account that Ívens saga likely passed to Iceland relatively shortly after its composition in Norway, as is indicated by some evidence of familiarity with the material early on in Iceland. $^{116}$

For Ívens saga three manuscripts are of textual significance. The first is Stockholm 6 4to (Royal Library of Sweden), which is the oldest manuscript to preserve the story, dating from the early fifteenth century. The second is AM 489 4to (Reykjavík, Stofnun Árna Magnússonar á Íslandi) from circa 1450, which holds a variant redaction. The third extant manuscript is dated much later (1690) and is now known as Stockholm 46 fol (Royal Library

\footnotetext{
113 'The Riddarasögur: A Medieval Exercise in Translation', Saga Book of the Viking Society for Northern Research 19 (1974), 403-41, 438.

${ }^{114}$ Barnes, 'Some Current Issues in Riddarasögur Research', 75-6.

${ }^{115}$ Rikhardsdottir, Medieval Translations and Cultural Discourse, 93.

${ }^{116}$ At the time Iceland was Norway's royal dependency. The Icelandic commonwealth ended around 1262-4, during the rule of King Hákon, see Rikhardsdottir, Emotion in Old Norse Literature, 2, 34.
} 
of Sweden). ${ }^{117}$ This paper manuscript is a copy of the now lost manuscript Ormsbók (c. 13501400 ) and, although it is greatly condensed, it nevertheless transposes passages not found in the older manuscripts, like the Pesme aventure episode. ${ }^{118}$ Other manuscripts preserving the text all derive from these three primary copies.

All three manuscripts contain compilations of several romances, 'indicating their generic and thematic coherence within their reading communities'. ${ }^{119}$ The oldest redaction of Parcevals saga (with Valvens páttr) attests to this, as it is transmitted in Stockholm 6 alongside Ívens saga. Although NKS 1794 b 4to (Royal Library, Copenhagen) is believed to predate the Stockholm codex by at least half a century, it consists of only a single fragment of one leaf. The story is additionally preserved in two defective seventeenth-century copies, AM 181a fol and AM 179 fol. (The Arnamagnæan Institute, Copenhagen). The separate tale of Valven (Gauvain) is moreover found in AM 573 4to (Copenhagen, The Arnamagnæan Institute), which dates from the fourteenth century.

The oldest complete texts of Erex saga are furthest removed from the story's presumed period of composition of all of Chrétien's Old Norse-Icelandic translations. The manuscripts Holm papp 46 fol. (Stockholm, Royal Library of Sweden) and AM $181 \mathrm{~b}$ fol. (Copenhagen, The Arnamagnæan Institute) are both dated to the second part of the seventeenth century. Two small strips of vellum (Reykjavík, Landsbókasafn Íslands Háskólabókasafn, Lbs 1230 III) that had been used for bookbinding in the seventeenth

\footnotetext{
${ }^{117}$ For a more detailed discussion of these manuscripts and their order of copying see Ívens saga, ed. and trans. Kalinke, 35-36.

${ }^{118}$ Ibid. 30-1. For more information on the transmission of Chrétien's romances in Ormsbók see Bjørn Bandlien, 'Arthurian Knights in Fourteenth-Century Iceland: Erex saga and Ívens saga in the World of Ormur Snorrason', Arthuriana 23.4 (2013), 6-37.

${ }^{119}$ Rikhardsdottir, Medieval Translations and Cultural Discourse, 83. This 'consciousness of genre' is, moreover, studied by Katharina Seidel, who examines the collective transmission of Ívens saga, Erex saga and Parceval saga (Textvarianz und Textstabilität, chapter 2).
} 
century transmit a limited number of words of a redaction from around 1500. Erex saga was also presumably included in the Ormsbók, but since this source is now lost, Erex saga is the most poorly transmitted translation of the three.

\section{Haerra Ivan}

Some fifty years after Hákon's death, a second wave of translation activity took place, this time at the behest of Queen Eufemia (1270-1312), the German wife of Hákon V Magnússon (King Hákon's grandson). ${ }^{120}$ The translative effort was likely in honour of a royal wedding. In 1302, Eufemia's daughter Ingiborg of Norway became betrothed to Erik, Duke of Sweden and brother to the King of Sweden. ${ }^{121}$ This union proved important for the inauguration of continental culture into Sweden and, in particular, for the development of a feudal society. Sweden did not lay down its first laws to regulate the existence of a noble class until the 1280s. ${ }^{122}$ The customs and norms characteristic of such a ruling class were introduced to Sweden via Norway. As a wedding present, Eufemia brought the courtly romance to Sweden by commissioning the translation of three poems, including Yvain, into Old Swedish. These are now known collectively as Eufemiavisorna or Eufemia's Lays. ${ }^{123}$

\footnotetext{
${ }^{120}$ For Eufemiavisor patronage see for instance William Layher, Queen Eufemia's Legacy: Middle Low German Literary Culture, Royal Patronage and the First Old Swedish Epic (1301), PhD dissertation, Harvard University, 1999, vii-x, 199-251.

${ }^{121}$ For more details on this union see Tony Hunt, 'Herr Ivan Lejonriddaren’ Mediaeval Scandinavia 8 (1975), 168-86, at 169. For a discussion of Eufemia's engagement as a literary patron in relation to her daughter's bethrothal, see Layher, Queenship and Voice in Medieval Northern Europe (New York: Palgrave MacMillan, 2010), chapter 4, 91-130.

${ }^{122}$ Olle Ferm, 'The Emergence of Courtly Literature in Sweden: A Critical Discussion of Swedish Research', in The Eufemiavisor and Courtly Culture: Time, Texts and Cultural Transfer. Papers from a Symposium in Stockholm 11-13 October 2012, ed. Olle Ferm, Ingela Hedström, Sofia Lodén, Jonatan Pettersson and Mia Åkestam (Stockholm: Kungl. Vitterhets historie och antikvitets akademien, 2015), 109-20.

${ }^{123}$ For more information on these texts within their historical context see for instance Olle Ferm, Ingela Hedström, Sofia Lodén, Jonatan Pettersson, and Mia Åkestam, eds, The Eufemiavisor and Courtly Culture:
} 
The Eufemiavisor additionally included one German and two French romances. Hertig Fredrik av Normandie (1308?) is said to be translated from a German text with a French origin. Flores och Blanzeflor (1312) is a translation of the Old Norse version of the French Floire et Blancheflor. It has similarly been suggested that the Old Swedish Herr Ivan Lejonriddaren (1303) was translated from both the Old French Yvain and its Old Norse rendition. ${ }^{124}$ On occasion, it reveals remarkable similarities with Ívens saga and it is now generally assumed that the Swedish translator used a copy of both works when composing the poem. ${ }^{125}$ The topic of the sources of Herr Ivan is examined in more detail in Sofia Lodén's doctoral dissertation on the literary transmission of the story in Sweden, in which she suggests that Ívens saga served as a translational aid in the process of transmission: ${ }^{126}$

Time, Texts and Cultural Transfer, Kungliga Vitterhets Historie och Antikvitets Akademien Konferenser 88 (Stockholm: Kungliga Vitterhetsakademien, 2015).

${ }^{124}$ These dates and order of composition for the Eufemiavisor are not universally accepted. Although these dates are given in the manuscripts themselves, some scholars argue that linguistically these adaptations cannot be dated as early as the beginning of the fourteenth century. Valter Jansson, however, beliefs that the language is influenced by the German verse tradition and argues in favour of this early dating (Eufemiavisorna: En filologisk undersökning, Uppsala aniversitets årsskrift, Recueil de travaux publié par l'université d'Uppsala 1945, Uppsala/Leipzig: Lundequistska bokhandeln/Harrassowitz, 1945). Henrik Williams, moreover, convincingly links the traditional dating to the historical context surrounding the commissioning of the translations (Hcerra Ivan, ed. and trans. Henrik Williams and Karin Palmgren, in Norse Romance, vol. 3: Hcerra Ivan, ed. Marianne E. Kalinke, Arthurian Archives 5, Cambridge: D.S. Brewer, 1999, 10-299, see Introduction at 5). The listing of two of the Eufemiavisor in a 1340 inventory belonging to King Magnus Eriksson indicates that the poems were in circulation by that time (Hunt, 'Herr Ivan Lejonriddaren', 170). The primacy in date of composition for Harra Ivan has recently become subject to debate. The manuscripts of Hertig Fredrik av Normandie are ambiguous in their date of translation and two copies indicate that the work was translated in 1300 or 1301, before the assumed date of completion given for Hoerra Ivan. The question of primacy is relevant inasmuch as it determines which text marks the beginning of Swedish fictional literature, see Layher, 'The Old Swedish Horra Ivan Leons Riddare', in The Arthur of the North, 123-44, at 129-30. For further discussion see Ferm, 'The Emergence of Courtly Literature in Sweden', in The Eufemiavisor and Courtly Culture, 109-20.

${ }^{125}$ See for instance Hunt, 'Herr Ivan Lejonriddaren', 171-73.

${ }^{126}$ Le chevalier courtois à la rencontre de la Suède médiévale: Du Chevalier au lion à Herr Ivan, $\mathrm{PhD}$ dissertation, Stockholm University, 2012; Lodén, 'Rewriting Le chevalier au lion: Different Stages of Literary 
Even though Chrétien's romance was the main model for the Swedish translator, the use of two sources allowed him to mix passages from the French text with others from the saga in a third, expanded version. However, one can imagine that the two sources of Herr Ivan did not share the same status. Translating from French was probably part of the ideological agenda of the translation. The Old Norse saga helped the translator in his work, but it was not the saga genre that the translator wanted to introduce, but the genre of the courtly romances. ${ }^{127}$

Herr Ivan, or Hoerra Ivan, is the only work by Chrétien de Troyes that we know was translated into Swedish. ${ }^{128}$ Like the other Eufemiavisor, it is written in knittelvers, a verse form that was imported from Germany. ${ }^{129}$ The translator is unknown. Hunt suggests that the author was a Swedish cleric in residence at the Norwegian court, who may have belonged to Duke Erik's entourage. ${ }^{130}$ William Layher, however, points out that while the translations were undertaken at the Norwegian court, there is no evidence of a Norwegian or of an Icelandic reception of the romance. ${ }^{131}$ There is further evidence of the reception within the East Norse tradition, as the Lays were transmitted into Old Danish in the late fifteenth

\footnotetext{
Transmission', in Riddarasögur: The Translation of European Court Culture in Medieval Scandinavia, ed. Karl G. Johansson and Else Mundal (Oslo: Novus, 2014), 91-106.

${ }^{127}$ Sofia Lodén, 'The Arthurian Legacy in Sweden', in Arthur of the North: Histories, Emotions, and Imaginations, ed. Bjørn Bandlien, Stefka G. Eriksen and Sif Rikhardsdottir, special issue of Scandinavian Studies 87.1 (2015), 62-73, at 62.

${ }^{128}$ Editor Erik Noreen adopted the shortened title of Herr Ivan (Herr Ivan: Kritisk upplaga, ed. E. Noreen, Uppsala: Almqvist \& Wiksell, 1931). Editors and translators Henrik Williams and Karin Palmgren prefer the normalised Old Swedish spelling, Horra Ivan, which this study will likewise adhere to.

${ }^{129}$ See for instance the introduction to Kalinke's edition of Hoerra Ivan, ed. and trans. Henrik Williams and Karin Palmgren, 3.

${ }^{130}$ Hunt, 'Herr Ivan Lejonriddaren', 172.

${ }^{131}$ Layher, 'The Old Swedish Horra Ivan Leons Riddare', 124.
} 
century. For Hoerra Ivan it is notable that both Old Danish versions were produced independently of one another, indicating, according to Layher, 'a livelier reception in the southern regions of this literary/cultural area than is commonly realized'. ${ }^{132}$

Hoerra Ivan is extant in four Swedish manuscripts, all of them miscellanies and all in Stockholm. Kungliga Biblioteket (Royal Library) holds three. ${ }^{133}$ Codex Holmiensis D4 was probably written in the cloisters of Vadstena and shows at least five scribal hands, the earliest hand dating from the first quarter of the fifteenth century, the latest around 1450. Codex Holmiensis D4a, known as 'Codex Verelianus' or 'Fru Märetas bok', can be dated to the same period, c. 1448. Codex Holmiensis D3, known as 'Fru Elins bok', is dated 1488 and its provenance can be ascribed to southern Scandinavia. Riksarkivet (National Archives) in Stockholm preserves the fourth codex, Skokloster-samlingen E8822 (formerly known as Codex Skokloster 156), a multilingual manuscript that contains both Old Swedish and Old Norse. It was written in the 1450s by Johannes, a friar in Bergen. The story is, moreover, preserved in translation in two Danish manuscripts, Codex Holmiensis K4 and K47, both held in the Royal Library in Stockholm.

\section{Ywain and Gawain}

The story of the Knight with the Lion seems to have been adapted for an English audience last, although it seems likely that it already circulated in England in Old French, whether through the Angevin royal family at the Norman aristocratic courts or through non-textual forms, as has likewise been suggested for Iceland above. The generally octosyllabic poem Ywain and Gawain appears to have been written in the first half of the fourteenth century, but

\footnotetext{
132 Ibid.

${ }^{133}$ For a description of the manuscripts see Layher, 'The Old Swedish Hoerra Ivan Leons Riddare', 123-25; and the introduction to Hcerra Ivan, ed. and trans. Williams and Palmgren, at 5-6.
} 
has come down to us only in an early fifteenth-century manuscript, that uniquely preserves the Middle English adaptation of the story. ${ }^{134}$ Cotton Galba E. ix was named after the wellknown collector of manuscripts Sir Robert Bruce Cotton, the only known curator of the codex. It is now in possession of the British Library in London.

Like Ívens saga and Hoerra Ivan, the Middle English poem is anonymous. Nothing is known about the author, his/her social environment or circumstances. The work is composed in rhymed couplets and written in a northern dialect, implying a northern provenance. ${ }^{135}$ Since the text reveals certain North-East Midland forms reflected in the rhyme it is assumed that the language is that of the original author. Despite the reduction of the story as we know it from Chrétien by some twenty-eight hundred lines, Albert B. Friedman and Norman T. Harrington have established beyond doubt that the English translator worked directly from a manuscript of Yvain, given the remarkable similarities in descriptive detail and the many instances of word-for-word translation. ${ }^{136}$ Although Chrétien's Yvain is not mentioned as a source, the poet repeatedly refers to 'the book': 'als sayes the buke' (9), 'as it telles in the boke' (3209), 'so sais the boke' (3671), 'Of tham na mare have I herd tell / Nowther in rumance ne in spell' (4027-8).

Mary Flowers Braswell likewise points out that, much more than Sir Perceval of Galles - a retelling of Chrétien's Perceval which the English poet took and made his own-

\footnotetext{
${ }^{134}$ Both editors Albert B. Friedman and Norman T. Harrington and editor Mary Flowers Braswell date the composition of the poem some fifty to one hundred years earlier, Friedman narrowing this down to between 1325 and 1350 (Ywain and Gawain, ed. Albert B. Friedman and Norman T. Harrington, Early English Text Society, Original Series 254, London/New York/Toronto: Oxford University Press, 1964, ix-xii). Admittedly there is not much evidence to substantiate this dating, as is pointed out by Braswell, since the lack of topical references complicate a more precise dating (Sir Perceval of Galles and Ywain and Gawain, ed. Mary Flowers Braswell, TEAMS Middle English Text Series, Kalamazoo: The Medieval Institute Publications, 1995, 77).

${ }^{135}$ For an introduction to the manuscript and its provenance see Ywain and Gawain, ed. Friedman and Harrington, ix-xii and lvi-lvii; and Sir Perceval of Galles and Ywain and Gawain, ed. Braswell, 77-79.

${ }^{136}$ Ywain and Gawain, ed. Friedman and Harrington, xvi.
} 
Ywain and Gawain retains the narrative and is to be regarded as a direct translation of its French example. ${ }^{137}$ She beliefs the abridgements to the story, which include the reduction of Chrétien's rich descriptive passages and character psychologising, to 'represent the English poet's conscious attempt at pandering to an audience who would eschew such subtleties in favour of a more fast-paced and action-filled plot' ${ }^{138}$ Indeed, from the outset the listener/reader is presented a tale of 'dedes of armes' (deeds of arms, 24) and of 'doghtines' (bravery, 27). Although the poem's main theme 'trowthe' (truth, appearing up to five time between lines 33-40) can be connected to Ywain's loyalty to Alundyne and love, it is likewise reflected in his friendship with Gawain in the Middle English version of the story. The narrative's focus on the friendship between the two Arthurian knights primarily lies in the combat of the two friends, who unknowingly fight eacht other as champions in an inheritance dispute, and is of course also indicated by the inclusion of 'Gawain' in the title of the work.

Dieter Mehl similarly notes that 'these changes show that the English adapter wrote for a completely different audience from that of Chrétien, an audience not very interested in ideals of knighthood and amour courtois, but expecting to hear of strange exploits, surprising adventures and many trials' ${ }^{139}$ Unlike the importation of the story into Scandinavia, its adaptation into the English literary tradition therefore does not seem to have been part of a civilising movement of the elite. Its colloquial use of language, instead, suggests that Ywain and Gawain was aimed at a less aristocratic but more rural, perhaps mercantile reading community. ${ }^{140}$

\footnotetext{
${ }^{137}$ Sir Perceval of Galles and Ywain and Gawain, ed. Braswell, 78.

138 Ibid. 79.

${ }^{139}$ The Middle English Romances of the Thirteenth and Fourteenth Centuries (Routledge Revivals) (London: Routledge, 2010, first published 1968), 128.

${ }^{140}$ Ibid. See also Keith Busby, 'Chrétien de Troyes English'd', Neophilologus 71.4 (1987), 596-613, at 603.
} 
As we have seen, the different European versions of Yvain are interrelated, some more directly than others. Although each individual rewriting doubtless had Chrétien's narrative as its source, the story did not necessarily move directly from French literary culture into these narratives' respective literary traditions. It is deemed likely that the story came to Norway via England, where it inspired a second wave of translation into Old Swedish. These possible routes of dissemination may explain why there is evidence of secondary influence between some of the different translations.

For its adaptation into Old Swedish it is generally assumed that Old Norse-Icelandic Ívens saga was used as a translational aid. Immediately in the opening lines such influences become clear, when, for example, the Swedish narrator follows the Norwegian in establishing Arthur as the equal in power and renown to Charlemagne, a detail absent in Chrétien's story. ${ }^{141}$ Horra Ivan, moreover, reveals influences from the Germanic literary tradition both in verse form and language. Given the German heritage of princess Eufemia, scholars have suggested a link with Hartmann's Iwein. Volker Mertens, for example, posits the existence of clear textual parallels between the two translations. ${ }^{142}$ Joseph Sullivan also notes '[a]lthough the Old Swedish poet changes his source material in different ways than Hartmann, he typically changes that material in the same places as does the Middle High German master. ${ }^{143}$ Furthermore, Julliette de Caluwé-Dor identifies clear differences in animal representation between the French and English versions, which she beliefs may be indicative

\footnotetext{
${ }^{141}$ See Hunt, 'Herr Ivan Lejonriddaren', 171-72. This correspondence is further examined by Joseph M. Sullivan in 'Arthur of the Northeast: The Old Swedisch Herr Ivan Redraws the King Arthur of Chrétien's Yvain', in Arthur of the North, special issue of Scandinavian Studies 87.1 (2015), 33-61.

142 'Die Eufemiavisor als Zeugnis deutsch-skandinavischer Kulturkontakte', Jahrbuch der Oswald von Wolkenstein Gesellschaft 16 (2006/2007), 159-78.

143 'Laudine: The Old Swedish Herr Ivan Adapts a Character from Chrétien's Yvain', Yearbook of the Society for Medieval German Studies 1 (2009), 50-75, at 53. For a listing of those instances and a discussion of Iwein as source for the Old Swedish translation see Lodén, Le chevalier courtois à la rencontre de la Suède médiévale, $42-45$.
} 
of secondary influences of the Welsh version in the textual transmission of Ywain and Gawain. ${ }^{144}$ These secondary influences make these 'translations' 'sources' in themselves.

The interrelation of the different European renditions of Yvain calls for an evaluation of the terms source and translation, denominators that for comparative reasons will be applied frequently in this study for Chrétien's text and its different renditions respectively. The next section presents such a methodological discussion of the terms source and translation as applied in this study. It looks in more detail at medieval translation practices to better conceptualise in what light the different renditions of Yvain should be viewed.

\section{Source and Translation}

Since the type of analysis carried out in this dissertation relies on close, often word-for-word comparisons, the terms source and translation will be used for Chrétien's narrative and its different renditions respectively. It should be pointed out, however, that although clearly delineable as modern nomenclature, both terms are misleading when applied to the broader context of medieval textual culture. Although much effort has gone into investigating alternate terms that do justice to medieval translation practices, I agree with Susan Bassnett that, on a lexical level, such attempts are ultimately 'a waste of time and ink', as the application of such modern denominators is not to be avoided when comparing several versions of one story without losing track of their interdependency. ${ }^{145}$ On a conceptual level,

\footnotetext{
144 'Yvain's Lion Again: A Comparative Analysis of its Personality and Function in the Welsh, French and English Versions', in An Arthurian Tapestry: Essays in Memory of Lewis Thorpe, ed. Kenneth Varty (Glasgow: University of Glasgow, 1981), 229-38. For an intertextual examination of the expressive behaviour of the lion in all the different Yvain versions see Chloé Vondenhoff, 'Een leeuw met menselijke trekjes', Madoc 29.1 (2015), $2-10$.

${ }^{145}$ Translation Studies, $3^{\text {rd }}$ edn (London/New York: Routledge, 2002), 4. Bassnett, moreover, suggests that the focus should be on the reader instead of the product, when examining medieval translation practices.
} 
however, such a terminological discussion itself is highly valuable.

For one, the delineation of these modern terms sheds light on medieval textuality and the period's conception of translation. Delineating these terms for Chrétien's Yvain and its different European renditions will, more importantly, clarify their interrelation while at the same time illuminating the parameters at play in the translation and dissemination of Chrétien's matière. In order to point out the somewhat misleading nature of source and translation, these terms will be examined from the three different perspectives of philological studies, translation studies, and comparative literary studies.

Firstly, the terms source and translation raise questions from a philological perspective. In contemporary translation studies, there is a clearly assignable original that we speak of as 'source' and which simultaneously is the 'source text' at the basis of a translation. This is seldom the case for medieval translations. Although we refer to Chrétien's story as the original 'source', it is important to remember that in philological terms we do not actually have that source. In theory, the closest we can get to the original source is if we could have acces to the manuscript in which Chrétien first wrote his story down. In practice, however, such autographs are almost always lost to us, as is the case with Yvain. What further complicates the notion of an originary source for medieval text tradition is that this autograph may not match the archetype, the text to originate the textual tradition of Yvain; the supposed ancestor for the manuscripts that survive today.

Chrétien is believed to have composed Yvain between 1170 and 1190. However, the manuscripts in which the story has come down to us are all from the thirteenth century or later. Medieval stories generally survive in later transmissions, which show variance to differing degrees. For this reason, the notion of an 'original source' for medieval stories like Yvain has become disputed. Since the rise of 'New'- or 'Material' Philology, such variance is, 
instead, believed to constitute medieval written culture. ${ }^{146}$ Medieval narratives, like Yvain, that are produced by a manuscript culture are no longer approached as static concepts, but as witnesses of mobility:

[T]he mere process of copying produces variation and fluidity, and so also do the subtle scribal changes in wording, word order, sentence construction and dialect, that constitute what Paul Zumthor calls the inescapable mouvance of the manuscript page. $^{147}$

While Zumthor does not necessarily draw on the genre of courtly romance to illustrate his point, the concept of mouvance nevertheless enhances our general understanding of medieval textuality as it foregrounds the inherent instability of vernacular literature, something that is certainly the case for the transmission of the narratives examined here. ${ }^{148}$ Zumthor, moreover, points out the impact of oral performance on this transmission. In the rare case that we do

\footnotetext{
${ }^{146}$ New Philology argues against the existence of a single lost source. It marks the break with traditional philology, which speaks for the existence of such an archetype for a medieval story. Central works for the discussion and introduction of this new type of textual research are: Bernhard Cerquiglini, Éloge de la variante: Histoire critique de la philologie (Paris: Editions de Seuil, 1989), published in English as In Praise of the Variant: A Critical History of Philology, trans. Betsy Wing (Baltimore: John Hopskins University Press, 1999) in which Cerquiglini gives his famous line 'medieval writing does not produce variants, it is variance' and Stephen Nichols, 'Introduction: Philology in a Manuscript Culture', Speculum 65.1 (1990), 1-10. Nichols later expressed a preference for the term Material Philology, to foreground the importance of the material aspects ('Why Material Philology? Some Thoughts', Zeitschrift für deutsche Philologie 116 (1997), 10-30).

${ }^{147}$ Jane H.M. Taylor, 'Rewriting, Translation, Continuation and Adaptation', in Handbook of Arthurian Romance, 176-82, at 168, summarising Paul Zumthor, Essai de poétique médiévale (Paris: Seuil, 1972), 65-75. ${ }^{148}$ Zumthor, Essai de poétique médiévale/Toward a Medieval Poetics, trans. Philip Bennett (Minneapolis: University of Minnesota Press, 1992). Mouvance is exemplified here within the genre of chansons de geste. The mutability of medieval stories was first addressed by Jean Rychner for their oral transmission, who ascribed oral traditions a caractère mouvant in La chanson de geste: Essai sur l'art épique des jongleurs (Geneva: Droz,
} 1995). 
have access to an autograph, the originary source, or perhaps sources, of that story will therefore still very likely have been oral. When examining the story of Yvain as a source, it is therefore important to remember, as has been so accurately addressed by the editors of the Handbook of Arthurian Romance, that:

When Chrétien de Troyes commenced composing his first Arthurian romances in the latter part of the twelfth century, he was writing within the context of a networked European storytelling tradition, the components of which had been largely disseminated through oral means. ${ }^{149}$

Like traditional philology, contemporary translation practice presupposes the existence of one source text at the basis of a translation. When approaching the relationship of source and translation from this perspective, the original source may be understood as the direct source, namely, the specific manuscript the different translators were translating from. However, unlike our current translation process in which one and the same original lies at the basis of numerous translations in different languages, there existed no such universal source for the different rewritings of Yvain. Each translator had a different source text they were translating from, none of which can be identified with certainty today.

Nor, in fact, do we have access to the original translation. Hartmann von Aue is believed to have composed his Iwein some thirty-five years after Chrétien, but the earliest manuscripts in which the Middle High German story survives are ascribed to the second quarter of the thirteenth century. This is still quite close to the presumed original when we compare it to the oldest manuscripts to have survived for the other Yvain versions. The extant

\footnotetext{
${ }^{149}$ Leah Tether and Johnny McFadyen, eds, 'Introduction: King Arthur's Court in Medieval European Literature', in Handbook of Arthurian Romance, 2.
} 
copy of the Middle English poem Ywain and Gawain dates from the early fifteenth century and thereby postdates its presumed original by almost a full century. The textual witnesses of the Scandinavian translations are probably the furthest removed from the time of their conception. Although Old Norse Ívens saga was presumably commissioned in the middle of the thirteenth century, the text has solely been preserved in later Icelandic manuscripts, of which the earliest dates back to the early fifteenth century. The same is true for the Old Swedish translation Hoerra Ivan of 1303, since the earliest hand of the presumed oldest surviving text witness is from the first quarter of the fifteenth century.

Thirdly, ascribing to Yvain the status of source compared to the other renditions as translations may be considered misleading from the perspective of literary studies. In $A$ Theory of Adaptation, Linda Hutcheon rightly argues that the notion of an original source is a fallacy, as each story is rooted in another, making intertextuality inevitable. ${ }^{150}$ Although Chrétien's romances are generally ascribed axiomatic primacy and authority, they were not created ex nihilo. His stories developed from Irish, Welsh and Breton legend, Provençal troubadour love poetry, as well as from the (pseudo-) historical tradition developed by chroniclers such as Geoffrey of Monmouth and Wace. Chrétien's romances not only give evidence of general influences, but contain very close borrowings from such works, whether of a lexical, thematic and/or stylistic nature.

Whereas today adaptation is often viewed as derivative according to some imagined hierarchy of the order of creation, building on the works of others was, in contrast, laudable in Chrétien's time. ${ }^{151}$ Such reworking took on different forms. Medieval writers would translate, adapt, rewrite or continue already existing works. These different types of reworking in turn

\footnotetext{
${ }^{150}$ A Theory of Adaptation (London/New York: Routledge, 2013). Although the volume focuses on film adaptation, Hutcheon is here talking about adaptation in general, including acts of translation.

${ }^{151}$ Ibid. 3. Hutcheon shows that contemporary audiences view the product of adaptation as a derivative creation as they know it to be temporally second.
} 
could include activities ranging from reinterpretation, reformulation, and/ or re-arrangement to extension and abbreviation. Rewriting provided medieval narratives with a sense of authority (auctoritas) and credibility. ${ }^{152}$ Jane H.M. Taylor even suggests that to the romanciers rewriting was 'a badge of honour'. ${ }^{153}$ She shows how Chrétien de Troyes is 'unapologetic - self-congratulatory in fact' when it comes to naming his sources:

[H]e has taken his Erec et Enide from a conte d'aventure [tale of adventure] seemingly doing the rounds of medieval courts (13-14); his Chevalier de la charrette (Lancelot) from not only a matiere but a san (26-27) provided by his patroness Marie de Champagne . . .; his Cligès from a manuscript kept in a book-press in Beauvais (18-30); his Perceval (Conte du Graal) from a livre [book] given to him by his patron Philippe d'Alsace, Count of Flanders (61-68). ${ }^{154}$

Likewise, Chrétien did not compose Yvain in isolation. Although there is no reference to a source by the poet himself and the exact origin of the story is therefore more difficult to narrow down, the fictional character Yvain is most likely based on the historical figure Owein, son of Urien, who fought against the invading Angles in Northrumbia in the sixth century. ${ }^{155}$ This warrior chieftain appears in numerous Welsh works and is most widely

\footnotetext{
${ }^{152}$ As has, for example, been shown by Douglas Kelly in The Art of Medieval French Romance (Madison: University of Wisconsin Press, 1992), 36-8.

153 Taylor, 'Rewriting, Translation, Continuation and Adaptation', 167.

${ }^{154}$ Ibid. The line numbers provided by Taylor refer to the prologues of these works. The opening lines of Cligès provide more evidence of rewriting practices by Chrétien himself. It lists a number of Latin works that are believed to have been translated into the vernacular early on in Chrétien's career, see p. 25 of this study.

${ }^{155}$ William W. Kibler, Introduction to The Knight with the Lion, or Yvain, Garland Library of Medieval Literature 48A (New York: Garland Publishing, 1985), xxv.
} 
known from the Mabinogion. ${ }^{156}$ Of the two stories that feature him in the Mabinogion, the Middle Welsh prose text Owain, neu Iarlles y Ffynnon (Owain, or the Lady of the Fountain) shows the most overlap with Chrétien's text. ${ }^{157}$

There are various contradicting theories about the interrelation of Yvain with this Welsh text. Particularly, the question of source and adaptation has fuelled much scholarly debate. While some have argued that the French text was the source for the Welsh version, others have suggested that the story is Celtic in origin. ${ }^{158}$ Since, philologically speaking, however, Yvain is the older text, a theory has been put forth that both stories derived from a common source. ${ }^{159}$ This theory has been sustained most elaborately by Arthur C. L. Brown,

\footnotetext{
${ }^{156} \mathrm{He}$ is also briefly mentioned in Geoffrey of Monmouth's Historia Regum Britanniae as 'Eventus the son of Urien' and in Wace's Roman de Brut as 'Ewein'.

${ }^{157}$ The other is Breuddwyd Rhonabwy (The Dream of Rhonabwy), which gives a radically different portrayal of Owain, not as a faithful knight to King Arthur, but instead as his opponent.

${ }^{158}$ Brynley F. Roberts, for example, suggests that Chrétien was the source for the Welsh romance: Studies on Middle Welsh Literature (New York: Edwin Mellen Press, 1992), 58. Ceridwen Lloyd-Morgan also argues for
} adaptation on the part of the Welsh author by pointing towards the existence of Welsh versions for Chrétien's other romances, Geraint ac Enid and Peredur fab Efrog, which are together with Owain known as the Three Welsh Romances ('French Text, Welsh Translators', in The Medieval Translator, ed. Roger Ellis, vol. 2. London: Centre for Medieval Studies, Queen Mary and Westfield College, University of London, 1991, 45-63, at 46-49). For a discussion of such theories see Lowri Morgans, 'Peredur Son of Efrawg: The Question of Translation and/or Adaptation', in Handbook of Arthurian Romance, 403-14.

${ }^{159}$ Llyfr Gwyn Rhydderch (The White Book of Rhydderch) and Llyfr Goch Hergest (The Red Book of Hergest), the two main source manuscripts to have survived for the Mabinogion, stem from c. 1350-1410, although most stories are believed to derive from much earlier oral traditions and were written down sometime between the eleventh and fourteenth centuries. Establishing a date of composition for the story of Owain is complicated by the fact that the different tales of the Mabinogion all have originated in different times and are of a different authorship, even though they were compiled as one work by Lady Charlotte Guest in the nineteenth century. Some of these preserve older legends of Arthur that seem to predate Chrétien (Culhwch and Olwen and The Dream of Rhonabwy), while others are indicative of a later tradition (Three Romances). See for example Sioned Davies, 'Written Text as Performance: The Implications for Middle Welsh Prose Narratives', in Literacy in Medieval Celtic Societies, ed. Huw Pryce (Cambridge: Cambridge University Press, 1988), 133-34; Idris Foster, 'Geraint, Owain and Peredur', in Arthurian Literature in the Middle Ages, ed. Roger Sherman Loomis (Oxford: Clarendon Press, 1959), 192-205. 
who has mainly pointed towards the Irish sagas Serglige Conculaind and Tochmarc Emere as a source. ${ }^{160}$ Brown's theory found reinforcement some forty-five years later through Roger Sherman Loomis, who indebted Chrétien's inspiration to Irish as well as Welsh tradition, in particular referring to Owain. ${ }^{161}$ Since then, however, scholars are more cautious in appointing a source, having come to the general agreement that it is impossible to determine primacy for either work. ${ }^{162}$ For this reason, the Middle Welsh story of Owain is not included in the cross-cultural comparison carried out here.

\section{Lost in Translation: Translation, Adaptation, Reworking?}

Despite the anachronistic notion of the existence of an 'original source' for medieval stories, past scholarship has insisted upon attributing most value to that which is temporally first. That is why most of the Yvain retellings have been perceived as 'lowering' the story of the Knight with the Lion and have long been characterised in negative terms. ${ }^{163}$ The close rendering of Chrétien's storyline has allowed for hierarchical evaluations of 'good' or 'bad', based on their faithfulness to Chrétien's work, without taking into account their different generic context and audience groups. Any deviations, whether of a structural, metaphorical or emotive nature, have therefore led to a labelling of the rewritings as if they were of inferior literary quality.

\footnotetext{
${ }^{160}$ Iwain: A Study of the Origins of Arthurian Romance (Boston: Ginn \& Co., 1903).

${ }^{161}$ Arthurian Tradition and Chrétien de Troyes (New York: Columbia University Press, 1949), 269-331.

${ }^{162}$ See for example Thomson, R.L., 'Owain: Chwedl Iarlles y Ffynnon', in The Arthur of the Welsh: The Arthurian Legend in Medieval Welsh Literature, ed. Rachel Bromwich, A.O.H. Jarman and Brynley F. Roberts, Cardiff: University of Wales Press, 1991, 159-69.

${ }^{163}$ With the exception of Hartmann von Aue's Iwein. The Middle High German adaptations of Chrétien's romances seem, for the most part, to be free of such negative judgements. The visibility of the author behind these literary efforts might explain why this is the case. Hartmann von Aue, like Perceval-adapter Wolfram von Eschenbach, was an acclaimed author in his own lifetime, known and celebrated by both German and nonGerman contemporaries.
} 
Friedman and Harrington's 1964 edition of Ywain and Gawain is an example of such studies that have judged these works by the literary competence of their authors. It compares the English poem with the French according to its regressions and its improvements. ${ }^{164}$ Although on many levels an exceptionally instructive description of the Old Swedish version, Hunt's 'Herr Ivan Lejonriddaren' likewise speaks about 'mistakes' versus 'positive gains' to describe deviations between the two texts and at times invites his reader to either 'admire the adaptor's skills' or 'to be disappointed' by them. ${ }^{165}$ Similar judgement has been passed upon the Old Norse-Icelandic translations of Chrétien's romances. Suzanne Marti shows that they have chiefly been criticised for their incomplete transcription of their French examples, noting that ' $\mathrm{g}]$ reat emphasis has been placed on the passages which the translators omitted or apparently failed to understand' ${ }^{166}$ Due to such criticism, these versions have for a long time been treated as if they were meagre variants of chefs-d'oeuvre, thereby not receiving the same scholarly attention as Chrétien's texts.

Recent scholarship, however, shows that these 'translations' are in need of reevaluation. Instead of focusing on what has not been replicated, literary historians have become concerned with the question of why this was the case, examining the potential motivations behind those transformations. Rather than ascribing deviations to the incompetence of a translator, they address them as translational choices that express meaning through different vehicles from Chrétien's. Consequently, they have started to question whether it is still appropriate to speak of translations when referring to these texts. The issue of terminology has mainly been addressed for the Scandinavian versions of Chrétien's

\footnotetext{
${ }^{164}$ Ywain and Gawain, ed. Friedman and Harrington, see section E and F, at xxvii-xxxi.

${ }^{165}$ Hunt, 'Herr Ivan Lejonriddaren', 177, 179, 186.

166 'Translation or Adaptation? Parcevals saga as a Result of Cultural Transformation', Arthuriana 22.1 (2012), 39-52, at 39. See also Barnes, 'Some Current Issues in Riddarasögur Research', 73-88 and Rikhardsdottir, Medieval Translations and Cultural Discourse, 1.
} 
romances, but is discussed in the broader context of epic and romance by Wim P. Gerritsen for Middle Dutch renditions of Old French texts. ${ }^{167}$ In 'Les relations littéraires', Gerritsen expresses the need for unequivocal terminology that allows the literary analyst to distinguish between the various types of translation when discussing these texts. He argues for the need to distinguish between translation (traduction), adaptation (adaptation) and reworking/rewriting (remaniement):

L'auteur d'une traduction proprement dite a l'intention de rendre le texte de son original aussi fidèlement que de lui permettent les données linguistiques et la poétique de la langue dans laquelle il traduit. Son oeuvre peut être considérée comme une rédaction en langue étrangère. Si, par contre, en traduisant, il s'écarte intentionnellement du texte de son original, le résultat de son travail peut être appelé une version étrangère. C'est ici que je voudrais faire une distinction. J'entends par adaptation le type de version estrangère dont l'auteur a abrégé, amplifié ou altéré, dans le dessein d'y mettre ses propres accents, le texte de son original, aussi longtemps qu'il s'en tient, dans ses écarts, à la fable de cet original. Je réserve le terme de remaniement à la version étrangère dans laquelle le fable, elle aussi, est modifiée. Un remaniement en langue étrangère peut être un véritable rifacimento de l'oevre originale. $^{168}$

\footnotetext{
167 'Les relations littéraires entre la France et les Pays-Bas au Moyen Âge: Quelques observations sur la technique de traducteurs' in Actes du septième congrès national de la Société Française de Littérature Comparée, Poitiers 27-29 mai 1965 (Paris: Didier, 1967), 28-46. For the Scandinavian translations see for instance Eyvind Fjeld Halvorsen, 'Translation - Adaptation - Imitation', Mediaeval Scandinavia 7 (1974), 55660, at 59; Kalinke, 'Scribes, Editors, and the Riddarasögur', 36-51; and Marti, who gives an instructive summary of the former studies ('Translation or Adaptation?', at 40).

${ }^{168}$ Gerritsen, 'Les relations littéraires', 34. The English translation is my own.
} 
[The author of a translation intends to render the text of the original as faithfully as the linguistics and the poetics of the language into which he translates allow him. His work can be considered a redaction in a foreign language. If, on the other hand, while translating, he intentionally departs from the text of his original, the result of his work may be called a foreign version. This is where I would like to make a distinction. By adaptation, I mean the type of foreign version in which the author has abbreviated, amplified or altered, with the intention of putting his own accents in the text of his original, as long as with these deviations he still adheres to the storyline of this original. I reserve the term rewriting/reworking for the foreign version in which the storyline, too, has been modified. A reworking in a foreign language may be a veritable 'rifacimento' [recasting, aimed at originality] of the original work.]

Although this delineation for the three different ways of 'translating' seems clear enough from the perspective of modern translation theory, medieval translation practices complicate a clear-cut distinction between the three and the application of a single category to one text. As is already indicated by Gerritsen, medieval translators did not only face linguistic difficulties, but also problems of a poetic nature when translating a text. This may have included the transformation of verse forms into prose, as was the case for Ívens saga. Although converting verse into prose completely alters the text's rendering syntactically, it does not necessarily modify its semantic representation. Should we then still speak of translation?

Translational issues of a poetic nature may, moreover, include the rendition of unknown metaphors and/or expressions, such as proverbs and colloquialisms. In the process of cross-cultural translation, the translator will have to choose between providing a literal translation and providing one that is meaningful to his/her audience. Source fidelity is thus a concept under discussion, as is for example, pointed out by Zrinka Stahuljak. She argues that 
there are two types of source fidelity: translation within 'the mode of intention of literalness of syntax', which is different from translation as a 'metaphor', within the mode of intention of 'fidelity in meaning'. ${ }^{169}$ The tension between these two modes of fidelity creates a double bind for interlingual translators, as both intentions cannot be realised at the same time.

This double bind was already addressed by church father Jerome (c. 350-420) and the Roman Philosopher Boethius (c. 480-524), whose theoretical principles regarding translation were influential throughout the Middle Ages. While Jerome favoured fidelity in style and meaning over word-for-word (verbum pro verbo) translations (with the exception of the Bible), Boethius pleaded for the latter instead. ${ }^{170}$ Although their discussions focused on the translation of biblical and philosophical texts, translators of literary texts faced the same translational dilemmas. In addition to fidelity in style and lexical meaning, what further complicates translation within the mode of 'intention of fidelity in meaning' for medieval translators of literary texts is the transcoding of socio-cultural meaning.

As we have seen, medieval interlingual translations within the epic and romance genre are very much 'target-oriented'. Cultural as well as literary conventions were often adopted into more familiar concepts that were meaningful for the targeted audience. This makes it hard to establish whether a translator, as noted by Gerritsen, 'departs intentionally from the

\footnotetext{
${ }^{169}$ Zrinka Stahuljak, 'An Epistemology of Tension', The Translator 10.1 (2004), 33-57, at 34-36, 46. Here, Stahuljak draws on the discussion of fidelity to a source text in relation to 'pure language', as theorised by Walter Benjamin ('The Task of the Translator', in Illuminations, ed. Hannah Arendt, trans. Harry Zohn (New York: Schoken Books, 1969, 69-82) and discussed by Paul de Man (“CConclusions”: Walter Benjamin's “Task of the Translator", in The Resistance to Theory, ed. Paul de Man, Theory and History of Literature 33, Minneapolis: University of Minnesota Press, 1986, 73-105). The tensions between these two modes of source fidelity are furthermore addressed by Umberto Eco in Mouse or Rat? Translation as Negotiation (London: Weidenfeld \& Nicolson, 2003), at 4-5.

${ }^{170}$ See Bart Besamusca and Gerard Sonnemans, 'De crumen diet volc niet eten en mochte': Nederlandse beschouwingen over vertalen tot 1550, Vertaalhistorie 6 ('s-Gravenhage: Stichting Bibliographia Neerlandica, 1999), 3-9.
} 
text of his original, with the intention of putting his own accents in the text', as would an adaptation or whether the deviation is caused by a translation of socio-cultural meaning, with the 'intention of rendering the text of the original as faithfully as possible'. What then should we call this change that is integral to making a text suitable for a new audience?

According to Hutcheon, the act of socio-cultural transcoding brings us into the realm of adaptation: 'Whereas translation is concerned with transposing material (words, images) of one semiotic system to another, adaptation takes this a step further, by reformatting this material into a new set of conventions as well as signs' ${ }^{171}$ The latter, however, makes adaptation difficult to theorise as it may include any act of alteration to the source. Just as the act of translation can come close to adaptation, adaptation may contain greatly modified parts from the original storyline, bringing us, according to Gerritsen's definition, into the realm of rewriting.

Likewise, the different renditions of Yvain do not fall into a single category, since they both foreignise and domesticate their source. Instead, they contain unique dimensions of translation. While some passages render their Old French source so linguistically close to be called translations, other parts reveal clear signs of adaptation and socio-cultural transformation that at times seem to be aimed at thematic originality and a reworking of the storyline. ${ }^{172}$ The different ways in which these renditions transpose their source strengthens the notion that medieval translation practices took on myriad forms and that we need to cast a wider net around medieval adaptations like those of Yvain. Rather than focusing on the product of adaptation by debating the degree of proximity to its 'original', we should approach the different Yvain-renditions in light of their adaptation process. After all,

\footnotetext{
${ }^{171}$ Hutcheon, A Theory of Adaptation, 16, my emphasis.

${ }^{172}$ Although this modification is not nearly as free as other reworkings of Chrétien's material such as Wolfram von Eschenbach's Parzival, a rewriting that expands Chrétien's material considerably, adding both scenes and characters in the process.
} 
Hutcheon notes that it is "no accident that we use the same word-adaptation- to refer to the process and product', as the one informs the other. ${ }^{173}$ It is precisely this definition of 'adaptation as a process' — of transmission, interpretation, renegotiation and thereby transformation — that this study seeks to highlight.

\section{The Translator as Mediator of Literary Cultures}

Defining adaptation as a process brings us closer to articulating a medieval theory of transmission, which is characterised by the topos of translatio. Unlike its lexical counterpart today, the medieval concept of translatio was less narrowly defined, but represented a broader conservatory notion, metaphorical in its description and use. In its broadest sense, the term translatio means 'to carry across' and signifies a process of transferral from one sphere to another, that may be geographical as well as geopolitical, from the East to the West. ${ }^{174}$ By the time of the later Middle Ages, the term was mainly used in connection to three contexts, as attested by translatio imperii, which 'signifies a transfer of power or dominion (from empire to empire, dynasty to dynasty)', translatio reliquiarum, which stood for the 'transfer of relics of saints (geographically and between different religions or churches belonging to the same

\footnotetext{
${ }^{173}$ Hutcheon, A Theory of Adaptation, 7.

174 The amount of literature on translatio is substantial. For a discussion of the concept of translatio see for instance Rita Copeland, Rhetoric, Hermeneutics, and Translation in the Middle Ages: Academic Traditions and Vernacular Texts, Cambridge Studies in Medieval Literature 11 (Cambridge: Cambridge University Press, 1991). Copeland focuses on translatio as a metaphor. For a further elaboration of the metaphoric use of translatio see Stahuljak, 'An Epistemology of Tension', 33-57. For a discussion of translatio as a medium for historical and cultural transposition, see Sif Rikhardsdottir, 'Chronology, Anachronism and Translatio Imperii', in Handbook of Arthurian Romance, 135-50, at 140-44. Vernacular equivalents of the term translatio in its meaning of linguistic transposition, such as translater for French, designated the same process of transference, as shown by Jessica Stoll, 'The Medieval French Lexicon of Translation', Neophilologus 99 (2015), 191-207.
} 
religion)', and, finally, translatio studii, which connoted 'the transfer of learning and knowledge' (from one geographic place to another). ${ }^{175}$

Within this context translatio denotes a process of appropriating the intrinsic authority and cultural prestige of an established literary work through linguistic translation. Not only does it refer to the physical translocation of the text (the manuscripts to transmit Yvain), but moreover, to the transferral of its less tangible contents (the story of the Knight with the Lion itself: its intention, ideology and underlying emotive script). ${ }^{176}$ While the intention of translatio was to ensure the preservation and continuation of a literary work, the movement of a story from one cultural context into another more often than not entailed contestation and thereby reformulation. Rita Copeland refers to this as the 'paradox of difference through replication'. 'As a rhetorical act', she notes, 'literary translation seeks to erase the cultural gap from which it emerges by contesting and displacing the source and substituting itself". ${ }^{177}$

Whereas Copeland shows this exclusively for vernacular translation in relation to medieval Latin culture, Rikhardsdottir examines this cross-cultural process between vernaculars within the romance genre. Within this transmission process, she writes, ' $[\mathrm{t}]$ he transposition by necessity realigns the very object that is being transposed rather than preserving it intact'. ${ }^{178}$ However, as much as the story is 'mutated, through its resignification within its new context', she notes, 'the object [here: in its conceptual meaning] is simultaneously preserved, as it captures a moment in time of its existence in the act of transference'. ${ }^{179}$ In tracing the process of translatio, Rikhardsdottir visualises literary translations to contain traces of both the original and the receiving cultures. She goes on to

\footnotetext{
${ }^{175}$ Stahuljak, ‘An Epistemology of Tension’, 38.

${ }^{176}$ Rikhardsdottir, 'Chronology, Anachronism and Translatio Imperii', 142.

${ }^{177}$ Copeland, Rhetoric, Hermeneutics, and Translation, 30.

${ }^{178}$ Rikhardsdottir, 'Chronology, Anachronism and Translatio Imperii', 142.

${ }^{179}$ Ibid.
} 
explain how the codes and signifying patterns of the translated text 'will need to be aligned to the pre-existing set of references [of the targeted literary tradition], whether linguistic, cultural, or literary, but will simultaneously reshape and reformulate those references. ${ }^{180}$ The literary conventions of the translating tradition will thus not entirely replace those of the translated text within the process of transferral, but rather the latter serves as an incentive for the enrichment of those conventions already existing in the target culture (and for its use of (poetic) language), thus changing the signifying framework and horizon of expectations of the targeted culture over time.

While the translatio topos is essential in grasping the origin and effect of medieval textual transmission, it fails to elucidate the act of transposition itself. For this conceptualisation, this study turns to Zrinka Stahuljak's contribution to Emma Campbell and Robert Mill's volume Rethinking Medieval Translation. ${ }^{181}$ In this article, Stahuljak argues against Lawrence Venuti's theory on the 'translator's invisibility' in an effort to foreground the human agency involved in medieval translation and interpretation. ${ }^{182}$ She visualises the medieval translator as a 'fixer', a term often applied in modern translation studies to describe human agents operating in conflict situations engaged in furthering communication between two parties by breaking down linguistic as well as cultural borders. In such studies, 'fixers', she explains, are 'identified as performing a range of duties in addition to interpretation and/or translation, acting as informants, guides, negotiators and more. . . we can think of

\footnotetext{
${ }^{180}$ Ibid. 141.

181 'Medieval Fixers: Politics of Interpreting in Western Historiography', in Rethinking Medieval Translation: Ethics, Politics, Theory, ed. Emma Campbell and Robert Mills (Cambridge: D.S. Brewer, 2012), 147-63.

${ }^{182}$ In The Translator's Invisibility: A History of Translation, Venuti argues against so-called 'domesticating practices' when it comes to translation, those translation acts that mask or remove all foreign influences in a story in favour of a more fluent and recognisable rendition for the receiving reader. Instead, he calls for the communication of linguistic and cultural differences, by allowing such foreign influences to exist in translation (London/New York: Routledge, 1995).
} 
fixers as mediators, go-betweens endowed with multiple linguistic, social, cultural etc. skills'. ${ }^{183}$ Stahuljak imagines medieval translators in a similar 'in-between' position. ${ }^{184}$ In this intercultural space, medieval translators - familiar with the linguistic and cultural systems of both the source and adopting language — act as careful mediators, assigned to 'fix' divergences between the two systems.

Approaching medieval translation as an act of linguistic and cultural mediation illuminates such an encounter within the realm of literary translation. ${ }^{185}$ Although Stahuljak foregrounds the medieval translator who operates in the contact zone of cross-cultural social engagement, the concept of the 'fixer' lends itself just as well to the medieval translator operating in the contact zone of cross-cultural text transmission. Medieval literary translations like the different renditions of Yvain can be said to qualify as a textual conflict zone, as these translations capture the linguistic, cultural, generic, and, in some cases, historical tensions when it comes to literary representation between two separate traditions.

As we have seen above, such tensions in emotive representation of the story of the Knight with the Lion may come to light by comparing the translations' respective emotive scripts. Any incompatibilities between the intrinsic emotive systems of these literary works ultimately go back to their audiences, as differences must be reconciled in such a way that the story is made comprehensible and enjoyable to its new 'audienceship', ${ }^{186}$ while still retaining those artistic and ideological codes for which the story crossed borders in the first place.

\footnotetext{
${ }^{183}$ Stahuljak, 'Medieval Fixers', 147.

${ }^{184}$ Ibid. 149. For a discussion of the position of the translator as spatially 'in-between' and its theorisation in modern translation studies see Maria Tymoczko, 'Ideology and the Position of the Translator: In what Sense is a Translator “in between”?', in Apropos of Ideology: Translation Studies on Ideology - Ideologies in Translation Studies, ed. María Calzada Pérez (New York: Routledge, 2014), 181-201.

${ }^{185}$ This encounter is examined in The Translator as Mediator of Cultures, especially in Vincent Colapietro's contribution, see 'The Poetics of Experience', in The Translator as Mediator of Cultures, ed. Humphrey Tonkin and Maria Esposito Frank (Amsterdam: John Benjamins Publishing Company, 2010), 107-24.

${ }^{186}$ Note that this is an implied audienceship, as re-constructed by the modern reader.
} 
Tracing this mediation between emotive scripts will help us elucidate the correspondences and divergences in the literary staging of emotionality between the original and the receiving textual traditions of the Yvain-story, as well as the possible socio-cultural conventions that may have motivated them.

\section{Research Question and Set-Up}

First and foremost, this study compares the emotive scripts of Chrétien's Yvain and its different medieval renditions. It discusses the adoption or, conversely, reformulation of the narrative's emotional representation by different textual traditions. In tracing this process of cross-cultural translation, this study seeks to highlight the engagement of the translator with language and culture in mediating between the literary standards for emotive representation (i.e. emotive codes) of the translated and translating tradition. It observes whether we can discern patterns in the way these emotive codes are mediated and rescripted in the different translations. The dissertation thus strives to answer the question what signs of engagement in linguistic and cultural mediation come to light when the emotive scripts of Yvain and its different European renditions are compared?

The following chapters explore this question in the form of three case studies. As such, these chapters do not aim at being comprehensive, but present a selection of passages from the Yvain-corpus to illustrate different types of emotive staging in Yvain and to explore how and why these narrative representations came to be adjusted in the process of crosscultural translation. Chapter one examines signs of the Old Norse translator's engagement in Ívens saga with Chrétien's metaphors of the heart and the Old French personhood construct cuer. The chapter looks in close detail at the intricate models of interiority in Chrétien's romances, images of the self that were so commonplace in Old French romance as to become 
standard tropes and motifs within the discourse of courtly love. How does the Old Norse translator, familiar with an emotive script that favours a spare and indirect emotive style, render Yvain's elaborate and emotionally excessive heart-imagery that is at the centre of the love ideal conveyed in the story?

Chapter two likewise compares Yvain's emotive script for courtly love, this time with that of the Middle High German Iwein. It investigates to what extent the German poem (A and B variants) engages differently with the love-dilemma presented in the story of Yvain by examining the restaging of the lovers' demonstrative actions and speech. Whereas chapter one focuses on the inner experience of emotion, chapter two foregrounds the outer expression of emotion through gesticulation and voice. It asks the question as to what emotional literary codes underlie the reformulated reconciliation scene of Iwein's B-redaction-in which the separated lovers reconcile in a significantly different manner - and offers further insight into the philological and reception-oriented issues raised by this ending.

In addition to studying emotion as an individual phenomenon, chapter three examines the renegotiation of Yvain's emotive script for the representation of collective emotions, still a relatively new topic of interest in literary studies. The chapter foregrounds the literary scripting of the communal feeling in scenes of arrival in Yvain and compares its various narratological functions for the Middle English Ywain and Gawain, as well as for Old NorseIcelandic Ívens saga. Both renditions reveal similarities in the way they redraw Chrétien's frequent staging of the communal feeling when it comes to the group's gender and hierarchy, as well as the number and length of its performances. The chapter therefore centres on the question: how do both textual traditions, known to favour a fast-paced narrative plot, engage with these repeated group performances? Can correspondences be assigned in the way the communal feeling is mediated in these texts? 
The concluding chapter will tie together the evidence of engagement with Yvain's emotive script gathered for each textual tradition in the individual case studies in order to reexamine the different Yvain-versions in light of the question of source fidelity posed in the introduction to this study. In rethinking the terminology surrounding medieval translation practices, the conclusion will, moreover, reflect upon the theoretical concepts emotive script(ing) and horizon of feeling adopted in this study and their applicability to the Yvaincorpus. 


\section{CHAPTER ONE: MEDIATING POETIC IMAGERY}

Matter(s) of the Heart in Yvain and Ívens saga ${ }^{187}$

By adopting and elaborating on imagery from Classical and Arabic literature, religious writing and contemporary troubadour poetry, Chrétien de Troyes's conceptualisations of love had a profound impact on the literary construction of courtly love as a heart-centred phenomenon. As the seat of emotion, the heart is the place where sensations are received and processed in Chrétien's romances. The inner struggles of his characters are typically conveyed through long poetic digressions that explore the inception of love within the heart and the effects of love-related sentiments on the individuals concerned. Such textual models give, often quite literally, insight into a character's self as they explicate the role the heart plays in relation to the senses and their interaction with external influences.

This chapter seeks to explore the transferral of Chrétien's conceptualisations of the heart as a feeling organ and of its love-related imagery into the Old Norse-Icelandic literary tradition. By tracing this cross-cultural transposition through close textual comparison, the chapter aims at illuminating both literary contexts. Firstly, it will consider literary conceptions of the heart and their respective ideologies in both French courtly romance and NorseIcelandic saga tradition. The semantics of Old French and Old Norse-Icelandic heartvocabulary will be elucidated for these two versions of the Yvain-story, as well as the heart's assigned properties and functions. Secondly, this chapter will compare the metaphorical

\footnotetext{
${ }^{187}$ Parts of this chapter have been published as Chloé Vondenhoff, 'Matter(s) of the Heart in Yvain and Ívens saga', in The Feeling Heart in Medieval and Early Modern Europe: Meaning, Embodiment and Making, ed. Katie Barclay and Bronwyn Reddan, Studies in Medieval and Modern Culture 67, MIP (Berlin/Boston: De Gruyter, 2019), 43-58.
} 
conceptions of the heart in both texts, with a particular focus on the heart in relation to sensory processes.

Chrétien's romances greatly contributed to the emergence of courtly love as a literary concept and to the dissemination of its discourse, as his representations of love in turn inspired later romanciers, local as well as further afield. Hence Emmanuèle Baumgartner asks, with regard to the influence of Chrétien's metaphors:

'How can one not be inspired by a discourse that dissects ad infinitum the sorrows and the joys of love and by long metaphors - for the fascinating beauty of the gaze of the beloved, for the arrow of desire, or for the heart alternately given, imprisoned, taken back or shared — that reach the pinnacle of refinement in Cligès, but also in Le Chevalier de la Charrette or Le Chevalier au Lion? ${ }^{188}$

While this inspiration is certainly true for Hartmann von Aue, who adopts Chrétien's tropes and motifs of love and at times greatly extends upon them, the appreciation and appropriation of courtly love imagery is still a matter of debate for the Old Norse-Icelandic rendition of Yvain. Although the general assumption is that Chrétien's stories were brought to Scandinavia for the sake of their courtly ideology, it has often been noted that those passages reflective of courtly love are abridged and omitted in their Old Norse-Icelandic translations. ${ }^{189}$ In King

\footnotetext{
188 'Chrétien's Medieval Influence', in A Companion to Chrétien de Troyes, ed. Norris Lacy and Joan Tasker Grimbert (Cambridge: D.S. Brewer, 2005), 214-27, at 222.

${ }^{189}$ See for instance Jonna Kjær, 'Franco-Scandinavian Literary Transmission in the Middle Ages: Two Old Norse Translations of Chrétien de Troyes_Ívens saga and Erex saga', in The Arthurian Yearbook, ed. Keith Busby, vol. 2 (New York: Garland 1992), 113-34, at 115; Bornholdt, ‘Old Norse-Icelandic Transmission' 100, 110. This has been argued for Hoerra Ivan to a lesser degree. Notably, this Old Swedish rendition is decidedly more 'romantically' oriented than its (in part) believed Old Norse-Icelandic source, perhaps due to its German
} 
Arthur North-by-Northwest, Kalinke, for instance, observes: 'If the Arthurian romances were imported in order to indoctrinate young men in the art of love, Hákon's programme surely failed, for those portions so characteristic of French romance, those sections that depict the progress and process of love ... usually received short shrift in the translations' ${ }^{190}$ In a similar vein, many scholars have over the years viewed such reductions and omissions as signs of a rejection of the courtly love conventions and have taken them to reflect a lack of interest in its ideology and imagery on the part of the Old Norse translators. ${ }^{191}$

Others, however, refute this stance. Both Daniel Sävborg and Robert Cook argue that the translators of the riddarasögur understood and repeated the overall courtly sensus (spirit) of the texts they reproduced. ${ }^{192}$ While not contesting the fact that passages reflective of French standards for the representation of love have been abbreviated and at times omitted in

patronage (Queen Eufemia) and royal targeted audience (her daughter Ingiborg of Norway and husband Erik, Duke of Sweden). Yet, the poem also contains evidence for a distinct Norse explanation of love-related sensations. A lover's image is, for example, held in the mind (hugha) instead of in the heart (ed. and trans. Henrik Williams and Karin Palmgren, 196-97; 3827-28; 6175-76). Whenever such reformulations in Hoerra Ivan are of a similar nature to alterations in Ívens saga, it will be indicated in a footnote in the textual comparison that is to follow below.

${ }^{190}$ Kalinke, King Arthur North-by-Northwest, 28.

${ }^{191}$ Christine Lorenz notes a general avoidance on the translator's part of Chrétien's observations on love, either through complete omission or through the editing out of specific love-elements ('Ór franzeisu i norrcenu': The transmission of Chrétien de Troyes' Arthurian Romances to Old Norse Literature, PhD dissertation, Durham University, 2007, at 133-38 and 323); Barnes, 'Some Current Issues in Riddarasögur Research', 73-88; Jónas Kristjánsson, Eddas and Sagas: Iceland's Medieval Literature, trans. Peter Godfrey Foote, 4th edn. (Reykjavík: Hiđ íslenska bókmenntafélag, 2007 [first published 1988]), 323.

${ }^{192}$ Daniel Sävborg, Sagan om kärleken: Erotik, känslor och berättarkonst I norrön litteratur, Acta Universitatis Upsaliensis, Historia litterarum 27 (Uppsala: Uppsala universitet, 2007), 230; Robert Cook, 'Concepts of Love in the Lais and in their Norse Counterparts', in Francia et Germania: Studies in Strengleikar and piðreks saga af Bern, ed. Karl G. Johansson and Rune Flaten, Bibliotheca Nordica 5 (Oslo: Novus Forlag, 2012), 53-86, at 61. Cook's study focuses on the adaptation of Marie de France's literary conceptions of love in Strengleikar, a translation that was like Ívens saga commissioned by King Hákon. In this chapter, he concludes that, 'the Norse translator respected and retained many passages in the French which dealt with the inner life of lovers' (77). 
the translated romances of Ívens saga and Erex saga, Sävborg nonetheless stresses that they also retain much of the love depiction and love concepts of their continental sources:

It should be noted that the features which are most important in the love depictions of the continental poetry still remain. The monologues about emotions and the psychological analyses are shorter in these riddarasögur than in the originals, but they still are typical features. The same is true of many of the other typical features of courtly love, for instance, the open love confessions, the amourous addresses, love sickness, the fire metaphors, Frauendienst, and the extreme reactions of grief on the death of the beloved. ${ }^{193}$

In his discussion of the adoption of courtly love-related imagery in, among others, Ívens saga, Sävborg does not include the textual transferral of the images named by Baumgartner; those specific tropes and motifs that are connected to the heart. How does the Norse translator reproduce this main symbol of courtly love that lies at the centre of much of the story's reflections on love and the inner lifes of its characters?

\section{Heart-Imagery in French Courtly Romance}

The heart features as a cardio-centric symbol in religious and political writing of the period, but can be found most prominently in the medieval romance tradition, where it became one of the leading images in the ideology of courtly love. Cultural historian Ole Martin Høystad

\footnotetext{
${ }^{193}$ Daniel Sävborg, 'The Sagas and Courtly Love', in The Viking Age: Ireland and the West. Proceedings of the Fifteenth Viking Congress, ed. John Sheehan and Donnchadh Ó Corráin (Dublin: Four Courts Press, 2010), 36168, at 363 .
} 
observes a surge of interest in the heart and its functions in the French romances of the twelfth and thirteenth centuries. In A History of the Heart, he shows how these romances created a 'cult of the heart', firstly through a general refinement of the emotional life of its characters and, more importantly, through the elaborate motifs of courtly love. ${ }^{194}$

Because of its multifaceted literary representation, courtly love is difficult to define. Stephen Jaeger assigns as its most prominent aspect '[a] love with an endlessly receding goal, which finds fulfilment only in longing, striving, aspiration'. ${ }^{195}$ In imitation of Aelred of Rievaulx's De Spiritali Amicitia (On Spiritual Friendship) and Andreas Capellanus's De Amore (About Love), treatises that renounced love of the flesh and promoted an image of 'sublime love' instead, courtly love, above all else, pursued an ideal of spiritualised love. ${ }^{196}$ Although not entirely platonic, this new paradigm endorsed a love that transmuted into something higher. The practitioner of this refined love-or fin'amor as it was named by the Occitan troubadours who brought the literary conception to the courts - 'was left in a constant state of yearning, but at the same time was left ennobled, more virtuous, as a result of this emotional state'. ${ }^{197}$ As a literary concept, courtly love was closely connected to the heart (cuer) as the locus of that love. The lover was to tame his desire and love his lady in his heart,

\footnotetext{
${ }^{194}$ A History of the Heart (London: Reaktion Books, 2009), 114-16.

${ }^{195}$ Ennobling Love: In Search of a Lost Sensibility (Philadelphia: University of Pennsylvania Press, 1999), 109_ 10.

${ }^{196}$ For a discussion of 'sublime love' in Aelred of Rievaulx and Andreas Capellanus see Jaeger, Ennobling Love, at 110-16. Unlike these discourses of sublime love, courtly love does not break with sexuality entirely, as was argued by Gaston Paris and C.S. Lewis. Chrétien, in fact, can be said to reconcile virtue with sex by playing with the tensions caused by this dualism, something Jaeger refers to as the 'romantic dilemma' of courtly love, see part 3, at 186. This dilemma, as well as the origin of the term amour courtois has been the subject of much critical debate. The concept of courtly love was questioned in the 1960s and 1970s, see for example Durant W. Robertson Jr, 'The Concept of Courtly Love as an Impediment to the Understanding of Medieval Texts, in The Meaning of Courtly Love, ed. Francis X. Newman (New York: State University of New York Press, 1968), 118; John F. Benton, 'Clio and Venus: An Historical View of Medieval Love', in ibid. 19-42; and John C. Moore, “"Courtly Love”: A Problem of Terminology', Journal of the History of Ideas 40 (1979), 621-32.

${ }^{197}$ Robert Cook, 'Concepts of Love', 55.
} 
by carrying around her image wherever he went or, alternatively, through a joining of hearts. ${ }^{198}$ As the site for love, as well as its main symbol, the heart thus literally and figuratively lay at the centre of the emotional ideal the courtly romances conveyed.

Chrétien de Troyes's stories are under the influence of this new fictional ideology and ubiquitously exhibit heart-imagery of this kind. Metaphors of the heart have primarily been discussed in reference to Chrétien's Cligès and Lancelot, narratives that mark the emerging literary popularity of 'romantic' love by the detailed psychological insights into the hearts of the stories' main love couples. ${ }^{199}$ Alexandre and Soredamors, Cligès and Fenice, Lancelot and Guinevere, practice, above all else, a metaphorical love, one that is characterised by its placement in the heart and its mediation through the senses. Literary scholars like Ruth Cline, Herbert Kolb and Claude Luttrell have examined these texts for their detailed poetic digressions on the relationship of the heart and the senses. ${ }^{200}$ Their studies show much of Chrétien's intricate imagery to build on earlier figures and motifs from Classical and Arabic literatures, as well as Christian writings, some of which ultimately reflect Aristotelian natural philosophy and (Neo)Platonic theories on the human sensorium. ${ }^{201}$ The human sensorium was

\footnotetext{
${ }^{198}$ For the origins of courtly love in the songs of the troubadours and trobairitz (female songwriters in Occitan), see William Reddy, The Making of Romantic Love: Longing and Sexuality in Europe, South Asia, and Japan, 900-1200 CE (University of Chicago Press, 2012), chapter 1. Reddy, moreover, attributes the conception of courtly love to the Gregorian Reform, 'a movement to reform church and society that popularised the conception of sexual desire as a kind of appetite that was to be tamed' (2-3).

${ }^{199}$ For Cligès see Ruth Cline, 'Heart and Eyes', Romance Philology 25 (1972), 263-97; Jody Enders, 'Memory and the Psychology of the Interior Monologue of Chrétien's Cligès', Rhetorica 10.1 (1992), 5-23; Claude Luttrell, 'The Heart's Mirror in Cligès', in Arthurian Literature 13, ed. James P. Carley and Felicity Riddy (Cambridge: D.S. Brewer, 1995), 1-18. For Lancelot see Gerard J. Brault, 'Chrétien de Troyes's Lancelot: The Eye and the Heart', Bulletin bibliographique de la Société internationale arthurienne 24 (1972), 142-53, 144. ${ }^{200}$ Cline, 'Heart and Eyes', 263-97; Herbert Kolb, 'Die Mystik des Auges und Herzens', in Der Begriff der Minne und das Entstehen der höfischen Lyrik, ed. Herbert Kolb, Helmut de Boor and Hermann Kunisch (Tübingen: Max Niemeyer Verlag, 1958), 18-38; Luttrell, 'The Heart's Mirror in Cligès', 1-18.

${ }^{201}$ Cline mainly points towards three routes of transmission: Classical and Arabic literature and Christian philosophy and poetry, while Kolb singles out the Augustian philosophers whom he believes to have carried
} 
a subject of inquiry throughout the classical period. This interest continued in the medieval period, with authors such as St Augustine and Isidore of Seville transmitting Latin and Greek views on the heart and the senses to Christian thought. ${ }^{202}$

Kolb and Cline, moreover, bring Chrétien's metaphors into connection with contemporary northern French and Provençal literature and identify parallels in the metaphorical representation of the heart for works such as the anonymous Le Roman d'Énéas and Thomas's Tristan, Marie de France's Lanval and the poetry of Bernart de Ventadorn. ${ }^{203}$ In these works, Gerard J. Brault writes, 'the heart is the very synonym for love. . . The heart may be spoken to; it preserves the image of the loved one; its yearnings may only be sated by the lover's kisses; it can break asunder or be torn out because of love's anguish. The heart receives joy and strength from the object of its affection. It may be locked in a coffer and unlocked by the key of love. ${ }^{204}$

In addition to a 'feeling heart', these French texts thus present us with a 'porous heart', that is 'quite literally, open to sensation'. ${ }^{205}$ The heart is susceptible to external influence, as is illustrated by the well-established motifs of love at first sight and the heart as the storehouse of memoria and affective rumination. Sensations from the outside world are

much of the tradition to the twelfth century poets. Luttrell at times argues for a more direct influence of Aristotelian psychology on Chrétien's work. Likewise does Guido Favati, who traces the influence of the Neoplatonic theory of vision on Chrétien's metaphors in Cligès ('Una traccia di cultura neoplatonica in Chrétien de Troyes: Il tema degli occhi come specchio', in Studi in onore di Carlo Pellegrini, Biblioteca di studi francesi, Torino: Società editrice internazionale, 1963, 3-13).

${ }^{202}$ The thirteenth and fourteenth centuries saw a further surge of interest in the topic, when increased contact with the East introduced Greek and Arabic commentaries on the senses, particularly on vision, to the West. For a more detailed description of this transmission process see the introduction to Richard G. Newhauser, ed., $A$ Cultural History of the Senses in the Middle Ages (London/New Delhi/New York/Sydney: Bloomsbury, 2014).

${ }^{203}$ Cline, 'Heart and Eyes', 263-97; Kolb, 'Die Mystik des Auges und Herzens', 18-38.

${ }^{204}$ Brault, 'Chrétien de Troyes's Lancelot', 143-44.

${ }^{205}$ Heather Webb, The Medieval Heart (New Haven: Yale University Press, 2010), 1-2. For a more elaborate discussion of the porous heart, see chapter 2 . 
described to travel through the sense organs into the heart, 'forming circulations that were not limited by the confines of a single human body'. ${ }^{206}$ Nor was the heart itself. It could leave the body in pursuit of the heart of the beloved and return to it.

Similarly, Yvain contains heart-metaphors of great complexity that have been largely overlooked in the above-named studies on Chrétien's love imagery. Although not always as lengthily and elaborately displayed as in Cligès, Yvain likewise features a heart that is closely connected to the generation and regulation of the affective states of its characters, particularly in relation to its main protagonists Yvain and Laudine. An examination of the heart and its imagery in Chrétien's Yvain is of particular value, since unlike Cligès, which was not as widely translated, Yvain contains concepts and motifs that were transmitted and adopted in other literary traditions.

\section{Heart-Imagery in the Old Norse-Icelandic Saga Tradition}

Whether we can speak of an appreciation and, what is more, appropriation of the courtly love tradition in Old Norse (literary) culture cannot be established with certainty. King Hákon’s interest in the translation of European romances such as Yvain has been attributed to his outward looking cultural politics. ${ }^{207}$ Bjørn Bandlien points out that 'we find few direct signs of a courtly love culture at King Hákon's court. This may be interpreted to mean that there were other aspects of knightly culture that appealed to Hákon more. ${ }^{208}$ He nevertheless argues that the riddarasögur reveal 'a dawning idealisation of love' as they engage with

\footnotetext{
${ }^{206}$ Ibid.

${ }^{207}$ For a more elaborate discussion of these politics see pp. 37-38 of this study.

${ }^{208}$ Bandlien, Strategies of Passion: Love and Marriage in Medieval Iceland and Norway (Turnhout: Brepols, 2005), at 219 .
} 
emotions and interiority in ways that the indigenous sagas rarely do. ${ }^{209}$ Larrington, moreover, illustrates that there is evidence for the appropriation of the vocabulary of courtly love, since it is through these translations of chivalric romance that kurteisi, a loanword from Old French cortois to describe courtly behaviour and love related manners, entered the Old Norse vocabulary. ${ }^{210}$

Despite the adoption of some of the generic conventions and emotional lexis of French courtly romance, Bandlien points out that there are also clear obstacles that can be assigned in the reconciliation of the discourse of courtly love with traditional saga conventions. ${ }^{211}$ For one, the male protagonist posed a problem in respect to this. As the heroic saga warrior suddenly had to give way to a reflective, feminised knight, the new discourse of courtly love clashed with the traditional discourse of masculine honour. Although the Old-Norse Icelandic literary corpus surely contained poems and stories of love, the ideal this love portrayed was vastly different:

Men were not supposed to be softened by feelings for women. The heroic portrayal of love was most concerned with the love and the honour a woman could give a man or take from him. Therefore, love was surrounded by a social brittleness: an individual's desire could really be a threat to society. ${ }^{212}$

\footnotetext{
${ }^{209}$ Bandlien, Strategies of Passion, 109

${ }^{210}$ Larrington, 'Learning to Feel', 86.

${ }^{211}$ Bandlien, Strategies of Passion, 12, 109, 147.

212 Ibid. 193.
} 
Therefore, Bandlien explains, 'if a man became weak for the sake of a woman, the ideal was for him to get rid of such feelings. ${ }^{213}$ What is more, clerical sources from the end of the twelfth century reveal a view of such love as sinful. ${ }^{214}$

In addition to a different love ideal, the indigenous saga tradition adhered to vastly different imagery for its representation of love. The saga characters generally do not confess their feelings to their beloved. In the Íslendingasögur (Sagas of Icelanders), also known as family sagas, 'love and erotic matters are primarily depicted through a limited group of motifs: a man and a woman talk to each other, a man and a woman sit together, usually the formula sitja/setjask hjá is used, a man visits a woman, or a saga character gives a gift of clothes to his beloved'. ${ }^{215}$ Representations of the heart in relation to love are rare in native Norse-Icelandic literature. In 'Das Herz in Edda und Skaldendichtung', Klaus von See identifies a general infrequency of heart-references in Old Norse prose and poetry. ${ }^{216} \mathrm{He}$ suggests that all references to the heart that are unconcerned with either 'courage' or, conversely, with 'fear', are in fact influenced by Christianity or the French romance tradition. $^{217}$

Traditionally, the personhood construct hugr (mind/heart-like conception) - the main translational substitute for Old French cuer in my discussion of Ívens saga below-featured as an image related to courage. According to Colin Peter MacKenzie, who has examined more

\footnotetext{
${ }^{213}$ Ibid. 148.

${ }^{214}$ Ibid. 120-26, 148.

${ }^{215}$ Sävborg, 'The Sagas and Courtly Love', 363.

216 'Das Herz in Edda und Skaldendichtung', Skandinavistik 8 (1978), 16-26, reprinted in Klaus von See, Edda, Saga, Skaldendichtung: Aufsätze zur scandinavischen Literatur des Mittelalters (Heidelberg: Carl Winter, 1981), 73-83. Somewhat more recently, Colin Peter MacKenzie has shown that there are, for instance, only two occasions in the corpus of the Íslendingasögur where the heart is used either in a cognitive or emotional context and assigns similar patterns to other genres of native prose (Vernacular Psychologies in Old Norse-Icelandic and Old English, PhD dissertation, University of Glasgow, 2014, at 94).

${ }^{217}$ Von See, Edda, Saga, Skaldendichtung, 81.
} 
than 1,600 occurrences of hugr across Old Norse-Icelandic literature, 'acting with hugr is a default expectation of the prototypical Old Norse-Icelandic hero'. ${ }^{218}$ We find much evidence of this in Eddic poetry. In Fáfnismál (Fáfnir's Sayings), for example, Sigurðr the dragonslayer claims that:

'Hugr er betri, enn sé hiors megin, hvars vreiðir scolo vega., 219

[ 'Courage is better than the power of a sword, where angry men have to fight.' $]^{220}$

The physical status of the hugr would often determine a character's nature in traditional Old Norse texts. A person who is described as being huglauss (literally 'without mind') or huglitill ('small-mind/small of courage') is cowardly, as opposed to a brave man or a hugmadr ('man of mind') who would be hugfullr ('full-mind/full of courage'). In Disturbances of the Mind and Body, Kirsi Kanerva explains that such expressions may either have alluded to the presence or absence of this mind-organ in characters, or may have alluded to the size of the heart that the hugr (mind) resided in. ${ }^{221}$ In some Old Norse-Icelandic texts,

\footnotetext{
218 ‘Old Norse-Icelandic Personhood Constructs', in Heart- and Soul-like Constructs across Languages, Cultures and Epochs, ed., Bert Peeters (New York: Routledge, 2019), 116-45, at 125. See also MacKenzie, Vernacular Psychologies.

${ }^{219}$ Edda: Die Lieder des Codex Regius nebst verwandten Denkmälern, Vol I: Text, ed. Gustav Neckel (Heidelberg: Carl Winter, 1962), 185, my emphasis.

${ }^{220}$ The Poetic Edda, trans. Carolyne Larrington (Oxford: Oxford University Press, 1996), 162.

221 'Disturbances of the Mind and Body: Effects of the Living Dead in Medieval Iceland', in Mental (Dis)Order in Later Medieval Europe, ed. Sari Katajala-Peltomaa and Susanna Niiranen, Leiden/Boston: Brill, 2014, 21942, at 228-29. This view is at variance with the representation of fear in later Old Norse-Icelandic texts that held that small hearts, containing little blood, belonged to the brave, while big hearts, filled with blood were ascribed
} 
such character traits may be passed on when either the heart or the heart's blood is consumed. For example, Hǫttr in Hrólfs saga kraka (Saga of King Rolf Kraki) turns into a valiant warrior after consuming the blood and the heart of a monster. In Snorri Sturluson's Ynglinga saga, Svipdagr feeds his foster-son Ingjaldr the heart of a wolf to cure his lack of strength. ${ }^{222}$

Classical representations of a heart that is in tune with the senses, like the arrow of love that strikes through the eyes into the heart, are virtually absent in native Norse-Icelandic literature. ${ }^{223}$ While such heart imagery survives in romances and religious texts across Western and Southern Europe, particularly in French and German romance and Italian poetry, there is no such trend discernable for the indigenous Old Norse-Icelandic tradition of the twelfth- and thirteenth century. ${ }^{224}$ According to Molly Jacobs, the Íslendingasögur and konungsasögur (Kings' sagas) only rarely employ sensory phenomena and when they do, they do not contain poetic descriptions or long digressions on the inner state of characters, but typically feature 'a spare style, characterised by parataxis and minimal description'. ${ }^{225}$ While

to the cowardly. Edel Porter and Teodoro Manrique Antón have argued that such instances may reveal the influence of humoral theory, that posed that a person's physical and mental health and temperament depended on the balance of the four humours (phlegm, yellow bile, black bile and blood) (Flushing in Anger, Blushing in Shame: Somatic Markers in Old Norse Emotional Expressions', Cognitive Linguistic Studies 2.1 (2015), 24-49, at 26). Kanerva points out that it is plausible that the native view may have represented a force rather than a substance (blood) ('Disturbances of the Mind and Body', 228).

${ }^{222}$ Similarly, in Hyndluljóð (Lay of Hyndla), Loki becomes impregnated after eating a wicked woman's heart, from which all evil on earth is said to descend. For a discussion of this motif in Old Norse-Icelandic literature see MacKenzie, Vernacular Psychologies, 97-100.

${ }^{223}$ For an examination of this motif in Strengleikar see Cook, 'Concepts of Love', 53-76.

${ }^{224}$ For German romance, see the works of Hartmann von Aue, Wolfram von Eschenbach, Gottfried von Strassburg and Heinrich von Veldeke, as for example discussed in Kathryn Starkey and Horst Wenzel, 'The Visuality of German Courtly Literature', Oxford German Studies 37.2 (2008), 130-59. For Italian poetry see for instance the Stilnovists, a group of thirteenth-century Tuscan poets, among whom Dante Alighieri, Guido Guinizelli and Lapo Gianni (The Medieval Heart, at 63-72; on Dante see for instance Carol J. Williams, 'Two Views of the Feeling Heart in Troubadour Song' in The Feeling Heart, 59-78).

225 “"Undir ilmöndum laufum ok nýsprungnum blómstrum”: Sensual Pleasure in Old Norse Arthurian Romance', in Arthur of the North, special issue of Scandinavian Studies 87.1 (2015), 107-28, at 108. For a description of 
female beauty may induce love at first sight, for example, the audience is not privy to the physiological process of how this comes about in the heart, nor to what the lover sees.

Interiority is generally indicated via indirect means in the sagas, through external somatic changes, such as blushing, shivering or turning pale. ${ }^{226}$ As will be discussed below, native Old Norse-Icelandic texts reveal a generic preference for emotional suppression or concealment as opposed to demonstration. ${ }^{227}$ It therefore seems that sensory descriptions in relation to a feeling heart indeed only entered the Old Norse-Icelandic tradition via the translated romances, which, in the word of Jacobs, 'fall somewhere between the extremes of their source texts and the native texts'. ${ }^{228}$ How does the Old Norse translator mediate between the conventions of these two vastly different literary traditions in his/her representation of heart-related love imagery? How are these deviating emotive scripts for the representation of love aligned in Ívens saga?

\section{Semantic Profiles}

The first mediation to be addressed when it comes to the Old Norse translation of Yvain's emotive script for courtly love is of a semantic nature. Ívens saga contains textual evidence for the translator's engagement with Old French cuer and Chrétien's representation of a predominantly feeling heart. Closest to Old French cuer in its cultural role as a personhood

what constitutes as 'typical saga style' see Otto Springer, 'The Style of the Old Icelandic Family Sagas', Journal of English and Germanic Philology 38.1 (1939), 107-28; and Theodore Andersson, The Icelandic Family Saga: An Analytic Reading (Cambridge: Harvard University Press, 1967).

${ }^{226}$ Sävborg, 'The Sagas and Courtly Love', 363.

${ }^{227}$ Kanerva, 'Disturbances of the Mind and Body', 226. See also William Ian Miller, 'Emotions and the Sagas' in From Sagas to Society: Comparative Approaches to Early Iceland, ed. Gísli Pálsson (Middlesex: Hisarlik Press, 1992), 89-110; and Kirsten Wolf, 'Somatic Semiotics: Emotion and the Human Face in the Sagas and Pcettir of Icelanders', Traditio 69 (2014), 125-45.

${ }^{228}$ Jacobs, “"Undir ilmöndum laufum ok nýsprungnum blómstrum”, 108. 
construct is Old Norse-Icelandic hugr, which we most often encounter as a translational substitute for cuer in Ívens saga. Hugr generally stands for 'mind', although its meaning is sensitive to variation. It alternatively translates as 'heart', 'spirit' or 'soul', depending on the context, genre and date of composition of the text we find it in. ${ }^{229}$

In later Old Norse-Icelandic texts, like the translated romances, hugr is typically associated with the mind. Its cognitive traits are evidenced by phrases such as koma i hug (come to mind, occur to one), vera i hug (to be in one's mind), ganga/ liða/hverfa ór hug (leave one's mind, forget), snúa hug sinum eptir/at/frá (turn one's mind after/to/from) etc. Hugr's role in thinking is further attested by the derived verbs hugsa (to think upon) and hyggja (to think, believe, intend) ${ }^{230}$ What is more, the appearance of hugr in close relation to hjarta (heart) — as frequently found in Ívens saga — underlines the first's cognitive functioning. In his study on vernacular psychologies in Old Norse-Icelandic literature, MacKenzie shows that although hugr and hjarta share a close relationship, they are not functionally synonymous: 'At one pole, hugr is almost exclusively responsible for cognitive functions, while at the other it is only hjarta which is represented as the vital, vivifying part of a person. ... This animating function is never applied to hugr and as such it allows us to separate hugr from hjarta in some degree'. ${ }^{231}$

Kanerva has likewise noted how hugr points towards 'the mind as a disembodied cognitive faculty, which existed in the breast, its actual physical organ being the heart (hjarta) ${ }^{232}$ This traditional view comes to poetic expression in kennings, used predominantly

\footnotetext{
${ }^{229}$ As is shown by MacKenzie with his examination of hugr across Old-Norse Icelandic literature in 'Vernacular Psychologies'.

${ }^{230}$ MacKenzie, 'Old Norse-Icelandic Personhood Constructs', in Heart- and Soul-like Constructs across Languages, Cultures and Epochs, ed., Bert Peeters (New York: Routledge, 2019), 121.

${ }^{231}$ MacKenzie, 'Vernacular Psychologies', 93-97. Textual examples from Old-Norse Icelandic literature to attest to this may be found at 94-96.

${ }^{232}$ Kanerva, 'Disturbances of the Mind and Body', 226.
} 
in skaldic poetry, that describe hjarta as 'the castle/house of the mind'. According to Kanerva, such descriptions suggest that 'mental functions were thought to be physical in nature, rendering every movement of the mind, emotions included, a bodily condition', as is suggested by the Old Norse word for (what we now call emotion) 'emotion', hugarhræring (movement of the mind). ${ }^{233}$ Both MacKenzie and Sarah Baccianti have found hugr's semantic profile to closely resemble that of Old English $m \bar{o} d$, which is likewise polysemous. ${ }^{234}$ Of its various meanings 'agitation of the mind' is, according to Baccianti, 'most relevant to the discussion of emotions and feeling in Old English', arguing that the mind as the centre of emotion located in the chest cavity is a concept that can readily be found in the Old English literary tradition. ${ }^{235}$

Similarly, in Snorri's Skáldskaparmál (The Language of Poetry) hugr is said to be housed in hjarta:

Hjarta heitir negg. Pat skal svá kenna, kalla korn eða stein eða epli eða hnot eða mýl eða líkt ok kenna við brjóst eða hug. Kalla má ok hús eða jǫrð eða berg hugarins. ${ }^{236}$

[The heart is called bosom. It shall be referred to by calling it corn or stone or apple or nut or ball or the like, and referring to it in terms of breast or [hugr]. It can also be called house or ground or mountain of the $[h u g r] .{ }^{237}$

\footnotetext{
233 Ibid.

${ }^{234}$ See MacKenzie, 'Vernacular Psychologies', 14-15; and Baccianti, 'Swelling in Anger: Somatic Descriptors in Old English and Old Norse Literature', in Emotion and Medieval Textual Media, ed. Mary C. Flannery (Turnhout: Brepols, 2018), 51-73, at 54-55.

${ }^{235}$ Baccianti, 'Swelling in Anger', 54.

${ }^{236}$ Snorri Sturluson, Edda: Skáldskaparmál, ed. Anthony Faulkes (London: Viking Society for Northern Research, 1998), 108, my emphasis.

${ }^{237}$ Snorri Sturluson, Snorri Sturluson: Edda, trans. Anthony Faulkes (London: Dent, 1987), 154.
} 
Snorri's lines suggest that hugr was physically associated with hjarta. However, while both terms may refer to the same organ and possibly a corresponding locus, they clearly denote separate entities, as is further attested by these lines from Hávamál (Sayings of the High One), a poem from the Poetic Edda:

Hugr einn pat veit, er býr hjarta nær,

einn er hann sér um sefa. ${ }^{238}$

[The mind alone knows what lies near the heart,

he alone knows his spirit. $]^{239}$

Although the relationship between the two is not made explicit, these lines present hugr and hjarta as separate entities, in which the first is ascribed cognitive functioning. Whenever Chrétien's heart-imagery is translated, cuer is likewise rendered a dual representation in Ívens saga, in which love is ascribed a mental agitation that nevertheless takes place in the heart. Ívens saga provides some text examples that make such a separation plausible, where hugr and hjarta appear side-by-side, signifying different faculties. ${ }^{240}$ Consider, for example, the following linguistic substitutes for cuer in Old Norse.

After her husband has been defeated at the hands of Yvain, Laudine, the Lady of the Fountain, is in need of a new lord to rule over her land and people (see Appendix, Synopsis,

${ }^{238}$ Edda: Die Lieder des Codex Regius nebst verwandten Denkmälern, ed. Necke, 31, stanza 95, my emphasis.

${ }^{239}$ The Poetic Edda, trans. Larrington, 27.

${ }^{240}$ The Old Swedish Hcerra Ivan likewise contains both translational substitues hugha and hicerta for Old French cuer, either independently or combined, as in 'af hiærta ok hugha' (with heart and mind) (ed. and trans. Henrik Williams and Karin Palmgren, 196-97; 839; 1099-1104; 1197-98; 1512-16; 2245). Note the rhyming couplet frugha-hugha in these lines, which may also have motivated certain lexical choices. 
episode II). Although initially distraught by the idea of accepting her husband's killer as her new lord, she is convinced by her maid Lunete to marry Yvain, who, after all, proved the superior knight in combat. W. R. J. Barron notes that despite Laudine's desire for revenge, 'Chrétien paradoxically insists upon their love in terms of the contemporary idealism of the prisonnier d'amour topos', presenting Yvain not only as physically trapped in the lady's castle, but also as a captive of her love. This double meaning resonates in Lunete's words when she goes to deliver her lady's message to the knight: ${ }^{241}$

'qu'avoir vos vialt en sa prison,
et si i vialt avoir le cors
que nes li cuers n'an soit defors'. ${ }^{242}$

['she wants to have you in her prison and she wants you imprisoned in such a way that not even your heart would be free'.]

In, what is essentially a metaphor for love, this imprisonment takes on rather literal form in Yvain, as lovers within the discourse of courtly love are presented as the keepers of each

\footnotetext{
241 'Chrétien and the Gawain-Poet: Master and Pupil or Twin Temperament?', in The Legacy of Chrétien de Troyes, ed. Norris J. Lacy, Douglas Kelly and Keith Busby, vol. 2 (Amsterdam: Rodopi, 1988), 255-84, at 279. ${ }^{242}$ Chrétien de Troyes, The Knight with the Lion, or Yvain, ed. and trans. William W. Kibler, Garland Library of Medieval Literature 48A (New York/London: Garland Publishing, 1985), lines 1924-27, my emphasis. All Old French quotations of Le chevalier au lion and their corresponding English translations cited in this dissertation have been taken from Kibler's 1985 edition. This edition is based on the so-called Guiot manuscript, Paris, Bibliothèque Nationale, fr. 794, and follows Paris, Bibliothèque Nationale, fr. 1433 and the Annonay manuscript whenever Guiot is in need of emendation. The text will hereafter be quoted with line numbers following the quotation.
} 
other's hearts. ${ }^{243}$ In Ívens saga, however, this imprisonment is rendered a dual represention. In addition to the heart (hjarta) — which could indicate here either the physical organ or possibly its affective faculty—-the Old Norse translator appoints the cognitive faculty (hugr) that the lady wishes to be master of:

'pvíat mín frú vill hafa pik sem hertekinn mann í sínu valdi, svá vandliga at eigi skal hugr pinn né hjarta vera ór hennar valdi'. ${ }^{244}$

['My lady wishes to have you in her power as captive, however, so entirely that neither your mind nor your heart shall escape her power'.]

The Old Norse translator seems to be mediating here between two different emotive scripts for the representation of love. Rather than aiming to possess a lover's heart, a petitioner often seeks power over their lover's mind in native Old Norse-Icelandic literature in obtaining their love. ${ }^{245}$

\footnotetext{
${ }^{243}$ Cline, 'Heart and Eyes', 265-66.

${ }^{244}$ Ívens saga, ed. and trans. Marianne E. Kalinke, in Norse Romance, ed. Marianne E. Kalinke, vol. 2: The
} Knights of the Round Table, Arthurian Archives 4 (Cambridge: D.S. Brewer, 1999), 33-102, p. 58, my emphasis. All normalised Old Norse quotations and their corresponding English translations in this dissertation have been taken from Kalinke's edition. The text of her edition is that of Stockholm 6 4to, but follows AM 489, AM 179 and Add. 4857, whenever the first proved illegible. The same edition is used for quotations from Erex saga, ed. and trans. Marianne E. Kalinke, 217-66, and Parcevals saga, ed. Kirsten Wolf and trans. Helen Maclean, 103-216. The first is extant in only two seventeenth-century manuscripts, AM 181b fol. and Stockholm 6 4to, which is also the base manuscript for Ívens saga, as well as for the text of Parcevals saga (with Valvens páttr). These texts will hereafter be quoted with page numbers following their quotations.

${ }^{245}$ See Bandlien, Strategies of Passion, 24-27. In Hávamál (Words of the 'High One '), for example, Óðinn seeks the love of a coy woman and succeeds in seducing her by convincing her mind: 'ef ec vil ins svinna mans/ hafa geð alt oc gaman,/ hugi ec hverfi/ hvítarmro kono/ ok sný ek hennar öllum sefa (161.2-6) (If I want to have all/ a clever woman's mind and love-play/ I can turn the thoughts of the white-armed woman/ and change her mind entirely.) [my translation] 
Ívens saga provides multiple examples of the addition of the mind to such metaphorical descriptions in Yvain. When the knight, for example, returns to the land of the Fountain to rescue Lunete from being burned at the stake, we learn that Laudine is still in possession of Yvain's heart, even though she turned him away for overstaying his leave (see Appendix, Synopsis, episode V). Upon his return, no one in his former household recognises their lord, who now appears before them as the Knight with the Lion:

\author{
et tuit a lor seignor ofrirent \\ lor servise, si com il durent, \\ sanz ce quë il ne le conurent; \\ neïs la dame, qui avoit \\ son cuer et si ne le savoit. (4582-86, my emphasis)
}

[and everyone there offered to serve the lord, as was proper, without knowing who he was, even the lady, who possessed

his heart but did not know it'.]

\begin{abstract}
Although Old Norse hjarta would putatively suffice here in translation, we again find the addition of hugr:
\end{abstract}

'Buðu pá herra Ív<en> fögnuð ok pjónustu sem peim sómdi, ok pektu pau hann ekki né frú hans. Hann hafði hirt hug sinn ok hjarta'. (82, my emphasis.) 
['They offered Sir Íven hospitality and service, as was proper, yet they did not recognise him nor did his lady. He had concealed his thoughts and heart'. $]^{246}$

Although the addition is minor, it may nonetheless be regarded as evidence for the semantic mediation (whether linguistic or cultural) of the personhood concept cuer that reveals a certain level of meticulousness on the part of the translator in his engagement with its Old French source. This impression goes against the image that is often painted of a translator who excises overly descriptive passages and concepts that he was supposedly not familiar with or that did not strike a cord with his audience. Along with the addition of hugr, the image of a travelling heart is redirected in the Old Norse adaptation of this passage. The rather literal phrasing in the Old French of 'having another's heart' —a motif frequently deployed by Chrétien in his romances as a heart that leaves the body to reside in another's - is an image the Old Norse translator may have chosen to move away from. Instead, Sir Íven is said 'to conceal his thoughts and his heart'. The motif of the heart being outside of the body is, in fact, consistently redirected throughout Ívens saga and will be discussed in more detail at the end of this chapter in the section 'The Itinerant Heart Motif'.

The representation of sensations as movements of the mind through the addition of hugr will be discussed throughout this chapter. This semantic transformation is not unique for Ívens saga. Von See has pointed out that the pairing together of hugr and hjarta is specific for texts within a Christian context and for the translated romances. ${ }^{247}$ Cook's comparison of courtly love imagery, including heart-related metaphors, in Marie de France's Lais and their Old Norse renditions in the Strengleikar, likewise reveals the dual alternative of hugr and

\footnotetext{
${ }^{246}$ Horra Ivan reformulates this into: ‘ Engin kænde hærra Ivan pær/ ok eigh hans eghin hiærta kær' (No one recognised Sir Ivan,/ not even his heart's beloved) (ed. and trans. Williams and Palmgren, 3817-18).

247 'Das Herz in Edda und Skaldendichtung', 81.
} 
hjarta for Old French cuer. $^{248}$ I will discuss one example here from Guigemar and its two Old Norse renditions:

\author{
Mes Amur l'ot feru al vif; \\ Ja ert sis quors en grant estrif, \\ Kar la dame l'ad si nafré, \\ Tut ad sun païs ublié. ${ }^{249}$
}

[But Love had now pierced him to the quick and his heart was greatly disturbed. For the Lady had wounded him so deeply that he had completely forgotten his homeland. $]^{250}$

In this passage, the knight Guigemar is struck by love in his heart. The Strengleikar text has:

En ast hævir nu skæint hug hans. ok hiarta I úro. pui at su hin friða fru. hævir lostet hann hugkœmelegre ast ok kænnir hann nu pat er hann kændi alldri fyrr. Allu hævir hann nu glœymt fostrlande, sinu fæðr ok frændom ok fostrbrœðrum . . .

\footnotetext{
${ }^{248}$ Cook, 'Concepts of Love', especially 67-69 and 77-78.

${ }^{249}$ Les lais de Marie de France, ed. Jean Rychner (Paris: Champion, 1966), lines 379-82, my emphasis, as cited in Cook, 'Concepts of Love', 68.

${ }^{250}$ The Lais of Marie de France, ed. and trans. Glyn S. Burgess and Keith Busby (London: Penguin Books, 1999).

${ }^{251}$ Guiamar, in Strengleikar: An Old Norse Translation of Twenty-one Old French Lais. Edited from the Manuscript Uppsala De la Gardie 4-7 - AM 666 b, 4, ed. Robert Cook and Mattias Tveitane (Oslo: Norsk Historisk Kjeldeskrift-institutt, 1979), 11-41, my emphasis, as cited in Cook, 'Concepts of Love', 68.
} 
[But love has wounded his mind and his heart is ill at ease because the beautiful lady has wounded him with sweet love. He feels now what he never felt before. He has now forgotten his native country entirely, his father and his relatives and his foster-brothers $\ldots]$

In Gvimars saga, the other version of the Old Norse Guigemar, it is similarly both the knight's mind and heart that are affected:

Nu kienner hann ad umm er snüed hug hanz og hiarta, jhugande pad ad sü hin frijda frü hefur losted hann öhugkvæmre äst, og kienner hann nu pad er alldrei kiende hann fyrr, òllu hefur hann gleimt fösturlande sijnu ...

[Now he realises that his mind and his heart are changed; he realises that the beautiful lady has smitten him with unpleasant love so that he now feels what he never felt before. He has forgotten his fatherland entirely ... ]

The rendition of cuer as both hugr and hjarta does not seem to be restricted to the emotion of love. In Parcevals saga, for example, we find it in combination with the emotions of sadness and regret. The French Perceval relates how in his long quest for the Grail, the knight loses his memory and completely forgets his faith. Upon Good Friday, he meets a group of penitent pilgrims on the road, who rebuke the knight for bearing arms on the day Christ gave up his life for mankind. Having been reminded of his Christian duties, Perceval realises his sins and undertakes to do penance himself, while:

\footnotetext{
${ }^{252}$ Gvímars saga, ed. Marianne E. Kalinke, Opuscula 7, Bibliotheca Arnamagnæna, 34 (Copenhagen: Reitzel, 1979), 106-39, at 128.6-9, my emphasis, as cited in Cook, 'Concepts of Love', 69.
} 
qui sozpire del cuer del ventre

por che que mesfais se sentoit

vers Dieu dont molt se repentoit. ${ }^{253}$

[sighing deep within his heart in his breast, because he felt he had sinned against God and was very sorry for it.] $]^{254}$

This highly emotional episode in Conte $d u$ Graal, in which the knight sheds many a tear, was considerable abridged in translation, which may have been due to the circumvention of a weeping knight protagonist. ${ }^{255}$ The summarising tone of the scene in Parcevals saga makes the addition of hugr in the equivalent Old Norse-Icelandic passage even more notable:

\footnotetext{
${ }^{253}$ Chrétien de Troyes, Le Roman de Perceval ou le conte du Graal, ed. Keith Busby (Tübingen: Max Niemeyer Verlag, 1993), lines 6334-36, my emphasis. Supporting text examples from Perceval will hereafter be quoted with line numbers following the quotation. Busby's edition relies most heavily on MS Paris, Bibliothèque Nationale, fr. 12576, but is accompanied by complete variants from the other manuscripts.

${ }^{254}$ Chrétien de Troyes, Arthurian Romances: The Story of the Grail (Perceval), trans. William W. Kibler (New York: Penguin Books, 1991), p. 459. The translated passages will hereafter be quoted with page numbers following the translation. Kibler's 1991 edition renders the story in prose and I'm following Kibler in my presentation of the translated text.

${ }^{255}$ The named transformation of the hero can be attributed to the assimilation of the knight protagonist to saga convention. On tears in Old Norse-Icelandic literature, see Bandlien, Strategies of Passion, 'Suppressed Tears', at 97-102. The image of the weeping knight (Chrétien tells us that Perceval's tears are continuously flowing from his eyes to his chin) is altered in Parcevals saga, however, as has been pointed out by Caroline Larrington, Parceval does 'learn how to feel' by the end of the story and is described 'on his knees and in tears' ('Learning how to Feel', 90). This rendition is in stark contrast with the Middle Dutch adaptation of the scene, which puts even more emotive emphasis on Chrétien's description of Perchevael's tears, see Frank Brandsma, 'Where are the Emotions in Scandinavian Arthuriana? Or: How Cool is King Arthur of the North?' in Arthur of the North, special issue of Scandinavian Studies 87.1 (2015), 95-106, at 104-5; and Brandsma, 'La véridicité des émotions dans le Perchevael, transposition en moyen néerlandais du Conte du Graal: Les larmes de Perchevael', in
} Fictions de vérité dans les réécritures européennes des romans de Chrétien de Troyes, ed. Annie Combes (Paris: Garnier, Fictions de vérité, 2012), 157-71. 
Sem Parceval var slíkt skiljandi, pá komz hann við mjök í hjarta sínu ok kom honum í hug hversu ferliga hann hafði lifat. (180, my emphasis)

[When Parceval understood this, he was very much touched in his heart, and it came into his mind how abominably he had lived.]

Where hjarta is here clearly stated as a feeling heart (as opposed to the physical organ), indicating the place where the sensation is felt, Parcevals saga simultaneously features the cognitive process involved in experiencing regret.

\section{Perception Model}

A similar rendition of cuer in Ívens saga that involves the dual representation of hjarta and hugr and underlines the cognitive function of the latter may be found right at the beginning of the story. Before we turn to the Old Norse text passage to illustrate this, we will interpret its French example.

As literary tradition dictates, the story of Yvain opens at King Arthur's court on Pentecost day, where we find knights and ladies gathering to exchange stories of past adventures and love (see Appendix, Synopsis, episode I). Calogrenant, one of Arthur's knights, is about to tell a tale of a failed quest. In a request for his auditors attention, he asks them to lend him their ears and, moreover, their hearts:

'Cuer et oreilles me rendéz, car parole est tote perdue 
s'ele n'est de cuer entandue.

De cez i a qui la chose oent

qu'il ententandent pas, et si lealoent;

et chil n'en ont ne mes l'oïe,

des que li cuers n'i entant mie,

as oroilles vient le parole,

aussi come li vanz qui vole,

mes n'i areste ne demore,

ei s'an part en molt petit d'ore,

se li cuers n'est si esveilliez,

qu'au prendre soit apareilliez;

car s'il le puet an son oïr

prendre et anclorre et retenir,

les oroilles sont voie et doiz

par ou s'an vient au cuer la voiz;

et li cuers prant dedanz le vantre

le voiz qui par l'oroille I antre.

Et qui or me voldra entandre,

cuer et oroilles me doit randre'. (150-71, my emphasis)

['Lend me your hearts and ears,

for words that are not understood

by the heart are lost completely.

There are those who hear something

without understanding it, yet praise it; 
they have only the faculty of hearing,

since the heart does not comprehend it.

The word comes to the ears

like whistling wind,

but doesn't stop or tarry there;

instead it quickly leaves

if the heart is not alert enough

to be ready to grasp it.

However, if the heart can take and enclose

and retain the word when it hears it,

then the ears are the path and channel

through which the voice reaches the heart;

and the voice, which enters through the ears,

is received within the breast by the heart.

So he who would hear me now

must surrender heart and ears to me'.]

Although the narrative shows Calogrenant relating his story to an intradiegetic audience (his fellow knights and the queen), it has been argued that this may well be Chrétien addressing his contemporary audience through extended narration, in what some literary scholars have argued to be (an extension of) the prologue to Yvain. ${ }^{256}$

\footnotetext{
${ }^{256}$ According to Peter Dembowski, the lapse into the third person during Calogrenant's tale—see line 358, 'je suis, fet il, uns chevaliers'- 'confirms our suspicion that an extended narration or description made by a protagonist-narrator becomes indistinguishable from the voice of the author-narrator himself' ('Monologue, Author's Monologue and Related Problems in the Romances of Chrétien de Troyes', Yale French Studies 51 (1974), 102-14, at 105). For a more elaborate discussion of narrative voice in this episode see Marcella Munson,
} 
The very existence and boundary of Yvain's prologue have been subject to much debate. While the opening scene clearly introduces the reader/listener to the story, it does not correspond to the traditional prologue that we encounter in Chrétien's other romances. Some scholars have argued that Calogrenant's appeal for attention in part does and therefore serves a type of prologue or is to be considered as part of the prologue. Marie-Louise Ollier shows antandre (understanding) [in the passage above: entandre] to be an essential element of the exordium (prologue) as it 'denotes the active receptivity demanded of the reader or listener'. ${ }^{257}$ Within Calogrenant's tale, she continues, 'antandre is the subject of a remarkable development, which constitutes in and of itself a sort of prologue'. ${ }^{258}$

Douglas Kelly shows auctorial appeals that allude to their listeners' cuer and oreilles in relation to antandre to be commonplace in medieval prologues. ${ }^{259}$ Authors would deploy such rhetorical formulae in the service of bringing about a connection with their audiences, to ensure their engagement with the story on a narratological, and more importantly, on an emotional level. ${ }^{260}$ Kelly therefore argues that the cuer et oreilles appeal is not merely reflective of the story's intended oral reception: 'Understanding is not based on discursive instruction alone. It takes place in the heart ... so that both author and public have access to the same deep-lying significance. Entendre is as far from mere listening as the author's

\footnotetext{
““Cil qui l'escrist”: Narrative Authority and Intervention in Chrétien de Troyes's Yvain', Paroles gelées 12.1 (1994), 27-45, at 31-38.

257 'The Author in the Text: The Prologues of Chrétien de Troyes', Yale French Studies 51 (1974), 26-41, at 33. See also Hunt, 'Beginnings, Middles and Ends: Some Interpretative Problems in Chrétien's Yvain and its Medieval Adaptations', in The Craft of Fiction: Essays in Medieval Poetics, ed. Leigh A. Arrathoon (Rochester, MI: Solaris Press, 1984), 83-117, at 85.

258 Ibid. 34.

${ }^{259}$ Kelly, The Art of Medieval French Romance, 119.

${ }^{260}$ Rhetorical handbooks tell us that the exordium (prologue) thus allows an author to delectare, docere and movere (to entertain, to teach, and to touch the audience), see Brandsma, 'Where are the Emotions?', 97.
} 
matière is from mere transcription of a source'. ${ }^{261}$ Entendre (understanding) is thus not for the ears alone, but also a function that can be ascribed to cuer. $^{262}$

The focus put by Calogrenant on the heart when listening to a story illustrates this well. In the passage above, Chrétien greatly elaborates on this commonplace allusion and presents story-processing as a physiological process, which is laid out step-by-step: words present themselves to the ears, like winds that are channelled through the ears to the breast where they are received by the heart. In this perception model, the ears function in service of the heart. They act as gateways to the body through which information enters the heart.

According to Claude Luttrell, the perception model in Calogrenant's speech builds on Aristotelian principles that had been introduced through indirect means of transmission into the West by Chrétien's time. ${ }^{263}$ In 'The Heart's Mirror', he presents multiple examples from Chrétien's romances in which a similar image of a heart attended to by the senses is found. In his cardio-centric model, Aristotle presents the heart as an active organ able to process input received by the senses. ${ }^{264}$ De anima as well as several of the treatises in the Parva naturalia

\footnotetext{
${ }^{261}$ Kelly, The Art of Medieval French Romance, 119.

${ }^{262}$ In his Etymologiae, Book 11, Isidore of Seville covers 'The human being and portents' (De homine et portentis) and describes the heart (cor) as 'the seat of understanding' (The Etymologies of Isidore of Seville, ed. and trans. Stephen A. Barney, Cambridge: Cambridge University Press, 2006, 11.i.119, at 239).

${ }^{263}$ Luttrell, 'The Heart's Mirror in Cligès', 1-18.

${ }^{264}$ Aristotle presents us with a heart-centred model that places the heart at the centre of bodily functions such as blood circulation and sense perception. In this model, the heart, as the seat of the faculty of perception, rules both motion and sensation. In contrast with Aristotle's centralised psychology is Galen's, and later Descartes' de-centralised model, which posed that many of the functions traditionally attributed to the heart belonged to the brain and the liver. Although the emotions remained localised in the heart, Galen established perception and cognition as functions of the brain. For a more detailed description of Aristotelian natural philosophy see Simo Knuuttilla, 'Aristotle's Theory of Perception and Medieval Aristotelianism', in Theories of Perception in Medieval and Early Modern Philosophy, ed. Simo Knuuttilla and Pekka Kärkkäinen (Dordrecht: Springer, 2008); Stephen G. Nichols, Andreas Kablitz and Alison Calhoun, eds, Rethinking the Medieval Senses:
} Heritage, Fascinations, Frames (Baltimore: John Hopkins University Press, 2008) especially part 1: Heritage; and Robert Jütte, A History of the Senses (Cambridge: Polity Press, 2005), 20-53. 
place the heart in the driver's seat as the sensus communis that transmits the sensations of the exterior world from the particular sense organs to the common sense-faculty. ${ }^{265}$ This representation of the heart gave rise to the medieval connection of the heart with memoria (memory). ${ }^{266}$

In the Middle Ages, memory was believed to reside in the heart. This locus was encoded in the Latin verb recordari (to recollect), whose etymology is said to trace back to revocare (to call back) and cor (heart) ${ }^{267}$ Isidore of Seville's entry for cor reveals the word is 'either derived from a Greek term, because they call it kardia, or from care (cura), for in it resides all solicitude and the origin of knowledge'. ${ }^{268}$ The knowledge retained by memoria was not just something to be 'learned by heart', but something to be learned from. Images mediated through the senses were believed to be stored in the heart in order to generate affective rumination and accordingly produce sensations. ${ }^{269}$

The medieval perception model recognised the five common senses, sight, hearing, smell, taste, and touch, as derived from Aristotle's De anima. Of these five, sight and hearing were generally ranked above the others, as they were attributed active agency in bringing

\footnotetext{
${ }^{265}$ Ibid. at 8, paraphrasing De Anima, Book 3 (i and ii); De Sensu, Book 7; De Memoria, Book I (450a and 451a); and De Somno, Book 2, which specifically locates the organ of the common sense in the heart (455a and b, 456a). For more information on his common sense organ see Kathy Eden, Poetic and Legal Fiction in the Aristotelian Tradition, especially part 3: Rhetoric and Psychology: The Aristotelian Foundation of the Poetic Image (Princeton: Princeton University Press, 1986).

${ }^{266}$ On the medieval concept of memoria, see Mary Carruthers, The Book of Memory: A Study of Memory in Medieval Culture, Cambridge Studies in Medieval Literature 10 (Cambridge: Cambridge University Press, 1990), especially at 52; Frances A. Yates, The Art of Memory (Chicago: University of Chicago Press, 1966). See moreover Isidore of Seville, The Etymologies of Isidore of Seville, ed. and trans. Barney, Book 11.i.18, at 232.

${ }^{267}$ Carruthers, The Book of Memory, 49.

${ }^{268}$ The Etymologies of Isidore of Seville, ed. and trans. Barney, Book 11.i.118, at 238.

${ }^{269}$ Carruthers, The Book of Memory, 75-78.
} 
about affective rumination. ${ }^{270}$ The operation of the senses in this process is perhaps best exemplified in Richard de Fournival's Bestiare d'Amours with regard to taking in a work of romance (in this case an example from the matter of Troy):

Memory has two doors: Sight and Hearing. And to each of these two doors a pathway leads, namely Depiction and Description. Depiction serves the eye and Description serves the ear. . . For when one sees the depiction of a history of Troy or of some other place, one sees the deeds of those past heroes as if they were present. And so it is with Description. When one hears a romance read, one hears the adventures as if one saw them in the present. And because one is converting past to present by these two things, namely Depiction and Description, it is clearly apparent that by these two things one can have access to Memory. ${ }^{271}$

In this thirteenth-century love bestiary, Fournival shows memoria to have the capacity to render the past as if it were present, as 'painture' (picture) and 'parole' (word), absorbed by the eyes and the ears, result into affective rumination. Visual and verbal effects therefore allowed one to learn from the past and were, according to Jeanette Beer, 'underscored as important means to inscribe a didactic message upon memory'. ${ }^{272}$

The opening scène of Yvain presents us with such a didactic message. Just preceding Calogrenant's conte de honte (tale of shame), we find knights and ladies gathering to exchange stories. One topic dominates their conversation: love. Chrétien introduces love as a

\footnotetext{
${ }^{270}$ Pekka Kärkkäinen, 'The Senses in Philosophy and Science: Mechanics of the Body or Activity of the Soul?', in A Cultural History of the Senses in the Middle Ages, 111-32, at 118.

${ }^{271}$ Jeanette Beer, Master Richard's Bestiary of Love and Response (West Hatfield: Pennyroyal Press, 1985), 12.

${ }^{272}$ Beasts of Love: Richard de Fournival's Bestiaire d'amour and the Response (Toronto: University of Toronto Press, 2003), 3.
} 
Leitmotiv to draw a critical comparison between lovers in Arthur's time with those in the present. In Arthur's days, he notes, love was 'riches et boens' (17) (sweet and flourishing), but today, 'very few serve love: nearly everyone has abandoned it; and love is greatly abased'. ${ }^{273}$ By inviting his listeners to make use of their eyes and look 'beyond those who are present among us and speak of those who were', the poet is instructing the audience to take to heart the ideal love present in Arthur's time, that is, the love depicted in his romance. ${ }^{274}$

The image of a memory served by the eyes and, more importantly, the ears, as it is painted by Fournival and which Chrétien's invitation for affective rumination is reflective of, is in line with the extended author-narrator's request for his auditors to 'lend him their ears and hearts'. The past adventures related of in Yvain are also to be learned from in the present. $^{275}$ This makes it plausible that the story Calogrenant presents us with is meant to be emotionally instructive, for the extradiegetic-, as well as the intradiegetic audience. Indeed, the knight Yvain, still a student of love at this point in the narrative, is a certified lover by the end of the story.

In the same manner, Gottfried von Strassburg asks his audience 'to lend me [your] hearts and ears' in the prologue to his Tristan. ${ }^{276}$ In correspondence with Yvain, the auctorial appeal follows a lengthy exposé (244 lines) on the nature of love, in which the narrator addresses the edele herze (noble hearts) of his audience:

ez kan wol lebene tugende geben;

\footnotetext{
273 'mes or i a molt po des suens/ qu'a bien pres l'ont ja tuit lessiee,/ s'an est Amors molt abessiee' (18-20).

274 'Mes or parlons de cez qui furent,/ si leissons cez qui ancor durent' (29-30).

${ }^{275}$ Kelly points out that romances were ultimatey written for future audiences: 'The desire to preserve and transmit the memory of the past, as outspoken in Marie de France as in Wace and Benoît de Sainte-Maure [and in Chrétien, whom he discusses at length with regard to the theme of making past deeds exemplary], is the immediate intention of all these works' (The Art of Medieval French Romance, 88).

${ }^{276}$ Gottfried von Straßburg, Tristan, ed. Rüdiger Krohn (Stuttgart: Philipp Reclam, 1980), line 243.
} 
wan swâ man hoeret oder list,

daz von sô reinen triuwen ist,

dâ liebent dem getriuwen man

triuwe und ander tugende van:

liebe, triuwe, staeter muot,

êre und ander manic guot,

daz geliebet niemer anderswâ

sô sêre noch sô wol sô dâ,

dâ man von herzeliebe saget

und herzeleit ûz liebe claget. (176-86, my emphasis)

[It [the tale] will enrich their lives. This it can well do. For wherever one hears or reads of such perfect loyalty, loyalty and other virtues commend themselves to loyal people accordingly. Affection, loyalty, constancy, honour, and many good things besides, never endear themselves anywhere so much as when someone tells a love tale or mourns love's tender grief.] $]^{277}$

In 'Where are the Emotions in Scandinavian Arthuriana', Brandsma argues that with these words Gottfried invites his audience to follow the good example set by the characters in the story: 'hearing about noble acts will make the audience behave in a noble way. The example of loyalty inspires loyalty in loyal people., 278

\footnotetext{
${ }^{277}$ Gottfried von Straßburg, Tristan, with the Surviving Fragments of 'Tristan' of Thomas, trans. A.T. Hatto (Harmondsworth, England: Penguin, 1960), 43.

${ }^{278}$ Brandsma, 'Where are the Emotions?', 98.
} 
The narrator in Jean Renart's Escoufle shows that even villains, those whose hearts are not noble, may take learning from the past:

Mais nus hom ne porroit manoir

En vilenie longement

Pour qu'il prestast entierement

A scouter cuer et oreilles

Cest roumant et les grans merveilles

Que cil dui fisent en enfance. ${ }^{279}$

[But no one could remain a villain provided he or she lend heart and ears fully to listening to this romance, and to the great marvels those two performed in their youth. $]^{280}$

Calogrenant's elaborate audite topos has been adapted with remarkable faithfulness by the Old Norse translator when we consider that the native saga tradition generally avoids detailed metaphors and lengthy descriptions of interiority. The Old Norse translator follows Chrétien's example closely, both on a lexical level as well as concerning the length of its description. However, the faculty responsible for story processing is modified, as we again find both hugr and hjarta in replacement of cuer. Other than Calogreant, Kalebrant's request seems to go out to the mind as the site for a cognitive processing of what is about to be told: ${ }^{281}$

\footnotetext{
${ }^{279}$ Jean Renart, L'escoufle: Roman d'aventure, ed. Alexandre Micha (Paris: Honoré Champion, 1992), lines 9052-57, my emphasis.

${ }^{280}$ This translation is Kelly’s and has been taken from The Art of Medieval French Romance, 119.

${ }^{281}$ This image of a 'thinking heart' as opposed to a 'feeling heart' as we find it in Ívens saga also resonates in Hoerra Ivan, in which Kalegrevanz ask for his listeners' reason and sense: 'Biper iak ok alla pær til lypa/ hvat
} 
'Verið vel skiljandi ok eyru til leggjandi, pvíat heyrð orð eru pegar tynd, nema hugr hirði pat er eyra við tekr. Peir verða margir optliga er pat lofa er peir eigi gá at skilja ok hafa eigi meira af, en peir heyra meðan hugr gleymir at skilja pvílíkt sem vind $<\mathrm{r}>$ fljúgandi ok nemr hvergi staðar. Svá fara pau orð er heyrð eru, nema hugr vaki við at taka; pvíat peir er mín orð vilja skilja, leggi bæði til eyru ok hjarta’. (39, my emphasis)

[Listen well and lend me your ears, for words heard are lost at once unless the mind preserves what the ears receive. Many often end up praising what they are unable to understand and from which they do not profit, and they hear while the mind forgets to comprehend just like the wind's breezes that do not come to rest. That is what happens to words that are heard if the mind is not awake to receive them. Let those who want to understand my words apply both their ears and heart.]

Like cuer, hugr is presented in this passage as an abstract function responsible for story processing. 'Understanding' (skilja) is repeatedly named as a faculty of the mind, ${ }^{282}$ except

min orp hava at pypa./ I pænkin pær a mæp vit ok sinne,/ riddara ok fruor ok stolta qvinna,/ hvat mik ær tempt ok ække drømpt,/ mæp mik var pæt æn aldrigh glømpt.' (I ask all of you to listen to/ what my words have to convey./ Consider with reason and sense,/ knights, ladies, and noble queen,/ what happened to me, but not in a dream;/ I have not been able to forget) (Harra Ivan, ed. and trans. Williams and Palmgren, 153-58). The lexicons vit and sinne are recurrently named throughout the poem as faculties of the mind (hugha) (153-58; $2155 ; 2177 ; 2310)$.

282 There exists no learned treatise in the Old Norse-Icelandic literary corpus that discusses a similar model for memory, nor how memorisation and rumination was thought to come about. Memory-related references in Old Norse-Icelandic literature are highlighted mainly in connection with Óðinn, the god of wisdom and his two ravens. In Grímnismál (Saying of Grímnir), memory is embodied as one of Óðinn ravens, Munnin, who, together with Huginn (thought), is portrayed as one of the two collaborating resources of the mind that fly over the world and bring him understanding of all things. In this representation, perception is clearly a faculty of the mind. For a 
for a final reference to the heart, that here seems to refer to the more substantial organ in which hugr, according to native Old Norse-Icelandic literature, resides. Can hugr then be said to correspond in profile and function to memoria?

Remarkably, the properties that affiliate the image of the heart as it is found in Calogrenant's request with the medieval model of memory have been modified in Ívens saga. For one, the detailed perception model presented by Chrétien has received a metaphorical redirection. Whereas in Yvain, the storyteller's words are presented as winds offering information to the ears that channel such information to the heart (157-58), in Ívens saga there is no specific point where the ears are the trajectory by which the voice gets to the heart. Instead, 'the wind's breezes that do not come to rest' are presented as a metaphor for 'the mind forgetting to comprehend' (39). As a consequence, the ears lose their imagery as doors to a person's memory.

Secondly, since there is no specific sense of the information brought to the ears being retained and stored in the Old Norse rewriting of Calogrenant's request, there is also no example presented to the audience to learn from. This may explain why the opening scene in which courtiers gather to exchange stories of love has been omitted in Ívens saga. The Old Norse-Icelandic translation does not reiterate the image of sublime love in Arthur's day in order to bring about affective rumination. Instead the translator has opted for a more factual image and invests more lines in situating the story and its characters in Roman history (Ívens saga, 38). ${ }^{283}$

discussion of this representation in relation to memory see Pernille Hermann, 'Memory, Imagery, and Visuality in Old Norse Literature', The Journal of English and Germanic Philology 114.3 (2015), 317-40, at 325-31.

${ }^{283}$ The Old Swedish Heerra Ivan likewise offers its audience a background history of King Arthur and his most famous deeds and extends the comparison drawn by the Norse translator between Arthur and Charlemagne. For a more elaborate discussion of the thematic redirection of the opening scene in Ívens saga, see Vondenhoff, 'Cuer me rendés... ': The Emotional Involvement of the Contemporary Audience in the Yvain-corpus, MA thesis, 


\section{The Heart-Eyes Motif}

According to medieval views on the senses, that go as far back as Aristotele as well as Neoplatonic thought, sensory perception was a two-way process: as gatekeepers, the senses are the trajectories through which sensations enter and exit the heart. ${ }^{284}$ In The Medieval Heart, Webb discusses this physiological movement as 'intercorporeal dynamism': 'each of the senses was imagined to bring something from the outside world into the heart. Such intake had a necessary correlate in outbound response, in the form of voice or projective spirits issuing from the eyes'. ${ }^{285}$ Yvain reflects a similar sensory model. As we have seen, the vocal movement in the act of telling a story is represented by Chrétien as an intercorporeal one: words leave the storyteller's heart to be channelled through the ears to the auditor's heart. As the vehicles through which sensations come about and through which they are reflected outward, the senses have a certain control over the heart.

Next to the ears, Chrétien ascribes such control to the eyes. Examinations of the relationship of the eyes to the heart have revealed some well-established metaphors within Chrétien's work. One of the more popular motifs of love at first sight has been frequently discussed in reference to Cligès. ${ }^{286}$ Cligès opens with the story of how the knight's parents, Alexandre and Soredamors, fell in love during their stay at Arthur's court. In the following

\footnotetext{
Utrecht University, 2013 at 47. Not only does the Swedish translator name reason and sense as the essential faculties for story processing, there is, moreover, no imagery of the senses as doorways, nor any other representation of a sensory model.

${ }^{284}$ See for example Chris Woolgar, 'The Social Life of the Senses: Experiencing the Self, Others, and Environments', in A Cultural History of the Senses in the Middle Ages, 23-44, at 24.

${ }^{285}$ Webb, The Medieval Heart, 53.

${ }^{286}$ See for example Cline, 'Heart and Eyes', 263-65; Peter Haidu, Aesthetic Distance in Chrétien de Troyes: Irony and Comedy in Cligès and Perceval (Geneva: Librairie Droz, 1968); Dana E. Stewart, The Arrow of Love: Optics, Gender and Subjectivity in Medieval Love Poetry (London: Associated University Presses, 2003); Luttrell, 'The Heart's Mirror in Cligès', 1-18.
} 
interior monologue, the narrative literally opens a window into the heart of Alexandre, who has been painfully struck by the arrows of a personified love:

'Ja n'il pert il ne cop ne plaie,

Et si t'an plains? Don n'as tu tort?'

'Nenil! Qu'il m'a navré si fort

Que jusqu'au cuer m'a son dart trait;

Ancor ne l'a a lui retrait.'

'Comant le t'a donc trait el cors,

Quant la plaie ne pert defors?

Ce me diras: savoir le vuel!

Par ou le t'a il tret?' 'Par l'uel.'

'Par l'uel? Si ne le t'a crevé?'

‘An l’uel ne m’a rien grevé,

Mes au cuer me grieve formant.'

'Or me di dinc reison comant

Li darz est parmi l'uel i antre,

Li cuers por coi s'an dialt el vantre

Que li ialz audi ne s'an dialt,

Qui le premier cop an requialt?'

'De ce sai ge bien reison randre:

Li iauz n'a soing de rien antandre

Ne rien n'i puet feire a nul fuer'. ${ }^{287}$

\footnotetext{
${ }^{287}$ Chrétien de Troyes, Cligès: Auf der Grundlage des Textes von Wendelin Foerster, ed. and trans. Ingrid Kasten (Berlin/New York: De Gruyter, 2006), lines 689-711.
} 
['But no bruise or cut appears, and still you complain? Are you not mistaken?' 'No indeed, for he has wounded me so deeply that he has shot his arrow straight into my heart and has not pulled it out again.' 'How could he have shot through your body when there is no sign of a wound? Tell me this, I'd like to know! Through where did he shoot you?' 'Through my eye.' 'Through your eye? Did he not put it out?' 'He did not hurt my eye at all, but I have a great pain in my heart.' 'Now tell me how the arrow passed through your eye without wounding or putting it out. If the arrow entered through your eye, why is the heart in your breast suffering and the eye not suffering, though it took the initial blow?' 'I can give you the answer to that: the eye itself is not concerned with feelings and can feel nothing on its own.' $]^{288}$

Chrétien's elaborate description of Alexandre being struck by Amor's arrow that inflicts the wound of Love — images that derive from Ovid's Metamorphoses—is strikingly concrete. ${ }^{289}$ The physiological particulars involved in the process of falling in love are set forth step-bystep, through a series of questions posed by the victim of love himself. Such detailed, inquisitive descriptions are not uncommon for Chrétien, as both Frank Brandsma and Mark Aussems have noted. ${ }^{290}$ The latter dubs such dialogues 'question passages', a clever narrative

\footnotetext{
${ }^{288}$ Chrétien de Troyes, Arthurian Romances: Cligès, trans. William W. Kibler (New York: Penguin Books, 1991), p. 131.

${ }^{289}$ Whose Art of Love Chrétien translated, as is stated in the opening lines of Cligès (1-3). The arrow of love was also a recurrent topos in the Christian tradition as representative of God's grace that could pierce the heart.

${ }^{290}$ Mark Aussems, 'Spiegelpersonages in Chrétiens Le chevalier de la charrette', Madoc 21.2 (2007), 23-31, which builds on Frank Brandsma, 'Mirror Characters', in Courtly Arts and the Art of Courtliness, ed. Keith Busby and Christopher Kleinhenz (Cambridge: D.S. Brewer, 2006), 275-82.
} 
technique that helps the narrator expand on issues in need of clarification. ${ }^{291}$ The channelling function of the eyes is given emphasis by the question of whether the arrow put out Alixandre's eye. ${ }^{292}$ The answer, no, suggests that sensations enter the body through figurative gateways that are the route to the heart, the place where the sensations are ultimately felt.

Peter Haidu explains the incongruity between metaphor and the literalness of Alexandre's rather absurd questioning in this passage to be an element of humour. ${ }^{293}$ Luttrell, however, maintains that the passage is reflective of contemporary optical theory that ultimately builds on a combination of Classical theories on the senses. 'In Cligès', he writes 'there is a synthesis of the NeoPlatonic theory of vision [the light from the object, here the lady's image or glance, striking through the eyes], with the Aristotelian doctrine of how the sense organs operate in relation to the heart [the seat of sense perception], ${ }^{294}$

Unfortunately, Cligès was, as far as we know, not rendered into Old Norse. However, a similar example of amor hereos, the lovesickness caused by Amor's arrow, is set forth in Yvain, in which the process of falling in love is laid out in a similar explanatory manner through a series of questions. ${ }^{295}$ When Laudine confronts Yvain with the death of her husband, the love-stricken knight places himself completely in her power. Somewhat surprised, Laudine asks the knight what strange force has overpowered him and he answers:

\footnotetext{
${ }^{291}$ Ibid. 25-26. This literary device may stem from the activity of lectio or the reciting of a text to an audience, during which listeners were free to ask questions.

${ }^{292}$ In the same manner, Soredamors blaims her eyes for having inspired love in her heart and she initially attempts to cure her lovesickness by refusing to look at Alexandre (Cligès, 493-99).

${ }^{293}$ Haidu, Aesthetic Distance, 60-61.

${ }^{294}$ Luttrell, 'The Heart's Mirror in Cligès', 11. See also, Stewart, The Arrow of Love, 13.

${ }^{295}$ Medieval romance typically foregrounds the physical aspect of amor eros or lovesickness, like the lovestricken subject in the examples set forth here. We find similar descriptions of the lover affected by a woman's beauty in the poetry of Bernart de Ventadorn, but also in non-poetic discourses like Andreas Capellanus' De Amore, see for instance Stewart, The Arrow of Love, 20-22. On lovesickness, see Mary Frances Wack, Lovesickness in the Middle Ages: The Viaticum and Its Commentaries (Philadelphia: University of Pennsylvania Press, 1990).
} 
'Dame,' fet il, 'la force vient,

de mon cuer, qui a vos se tient;

an ce voloir m'a mes cuers mis.'

'Et qui le cuer, biax dolz amis?'

'Dame, mi oel.' -- 'Et les ialz, qui?'

'La granz biautez quë an vos vi.'

'Et la biautez, qu'i a forfet?'

'Dame, tant quë amer me fet'. (2019-26)

['My lady', he said, 'the power comes

from my heart, which is set on you;

my heart has given me this desire.'

'And what controls the heart, good sir?'

'My eyes, my lady'. 'And what controls your eyes?'

'The great beauty I see in you.'

'And what wrong has beauty done?'

'My lady, such that it makes me love'.]

In this passage, Chrétien specifically addresses the role of the eyes in the process of falling in love. As the agents responsible for bringing about the sensation of love, they not only perceive the image of beauty, but also have control over the heart.

Chrétien's heart-eyes imagery has received a systematic reformulation in its adaptation into the Old Norse literary tradition. Any references to the senses as representing 
doorways or conduits to the heart have either been omitted or transformed. Íven's explanation for his sudden infatuation does not involve channels such as the eyes:

'Í pvílíkan vilja nauðgar mik mitt hjarta,' sagði hann. 'Fyrir hverjar sakir?’ segir hún. Pín hin fýsiliga fegrð,' sagði hann. 'Hvat hefir fegrð mín misgert við pik?’ sagði hún. 'Frú,’ kvað hann, 'pvíat hún gerir mik elska’. (60)

['My heart forces this good will on me,' he says. 'For what reason?' says she. 'On account of your desirable beauty,' says he. 'What misdeeds has my beauty done against you?' said she. 'Lady,' he said, 'because it makes me love'.]

Since this is an almost word-for-word rendering of the Old French source-even the inquisitive form has been copied — the omission of the eyes is remarkable. Although the modification is minor, alterations of a similar nature suggest that the omission should not simply be dismissed as an eye-skip on the part of the translator or later scribe, nor as a curtailment of a resumptive nature, but may in fact point towards an avoidance of said sensory models in translation. ${ }^{296}$

\footnotetext{
${ }^{296}$ The same may be argued for Hcerra Ivan. The Old Swedish translator again names both heart and mind as the faculties for love: 'Nu sitin nær mik, min hiærte kære,/ ok sighin pæt mik mæp rættan skil,/ huru pæt ær Iper sva komit til/ pæt I mæp hicerta ok sinne/ ælskin mik for alla qvinna.' (1512-16) ('Now sit down beside me, my dearest,/ and tell me clearly,/ how it has come about/ that with heart and mind/you love me above all women.'). Ivan's answers does not include the eyes: Iper fæghrind haver mit hiærta spænt' (1519) ('your beauty has fettered my heart'). Although there is evidence for strong native associations with the sense of sight, such literary representations mainly foreground its association with supernatural power, which may explain this redirection. The description of Óðinn as one-eyed draws attention to the sense of sight. Pórr is, moreover, characterised as having a powerful stare. For a discussion of sight in Old-Norse Icelandic literature see Jacobs, “"Undir ilmöndum laufum ok nýsprungnum blómstrum”, 112-14; Jacobs, “"Hon stóð ok starði”: Vision, Love, and Gender in Gunnlaugs saga Ormstungu', Scandinavian Studies 86.2 (2014), 148-68; Herman, Memory,
} 
Many more examples can be brought forward in support of this theory. However, not all of Chrétien's digressions on the senses and their relation to the heart, it seems, could be remediated with such minor modification. Metaphors reflecting Aristotelian perception models have either been omitted in their entirety or have received substantial reformulation in translation. The first type of remediation is difficult to exemplify since it may just as well be attributed to a more general tendency on the part of the Norse translator to do away with overly descriptive language in favour of a more streamlined story. However, a suitable example to demonstrate remediation by omission is provided by the Old Norse-Icelandic translation of Erec et Enide.

After Erec has won the sparrow hawk contest in Enide's name, he takes Enide to Arthur's court, where a wedding is prepared for them. After the bridal ceremony, the story zooms in on a different medieval rite: the bedding. The narrator in Chrétien presents the audience with both the formal and emotive details of this union. First he relates how 'la nuit, quant il assembler durent,/ Evesque et arcevesque i furent. . . . la reine s'est antremise/ de l'atorner et del couchier,/ car l'un et l'autre avoit molt chier.' ${ }^{297}$ (on that night when they were to unite, bishops and archbishops were present. ... The queen took charge of the preparations and the bedding for them, for she dearly loved them both). ${ }^{298}$ Next, the reader/listener receives a more intimate description of their union:

Images, and Visuality, 328-29. For a discussion of eyesight in relation to supernatural power see Lassen, Øjet og Blindheden.

${ }^{297}$ Chrétien de Troyes, Erec et Enide, ed. and trans. Jean-Marie Fritz, Livre de Poche 'Lettres Gothiques' (Paris: Librairie Générale Française, 1992), lines 2069-76. Supporting text examples from Erec et Enide will hereafter be quoted with line numbers following the quotation.

${ }^{298}$ Chrétien de Troyes, Arthurian Romances: Erec and Enide, trans. Kibler, p. 62. The translated passages will hereafter be quoted with page numbers following the translation. Kibler's 1991 edition renders the story in prose and I'm following Kibler in my presentation of the translated text. 
Cele nuit ont mout restoré

De ce qu'il orent demoré.

Quant vuidie lor fu la chambre,

Lor droit rendent a chascun mambre;

Li huil d'esgarder se refont,

Cil qui d'amors la voie font

Et lor message au cuer envoient,

Car mout lor plait quanque il voient.

Après le message des iauz

Vint la douceurs, qui mout vaut miauz,

Des baisiers qui amors atraient.

Andui cele douceur essaient

Et lor cuer dedanz en aboivrent,

Si que a poinnes s'en dessoivrent. (2083-96)

[That night they fully made up for what they had so long deferred. When they were left alone in the room, they paid homage to each member. The eyes, which channel love and send the message to the heart, renewed themselves with looking, for whatever they saw greatly pleased them. After the message from the eyes came the sweetness, worth far more, of the kisses that bring on love; they both sampled that sweetness and refreshed their hearts within, so that with great difficulty they drew apart.] (63) 
Although the ceremonious aspect of the bedding has been faithfully copied, the heart-imagery applied to the actual union is omitted in Erex saga, which fast-forwards to describe the duration of the wedding festivities:

En at kveldi leiðir dróttning jungfrúna til sængr, en Erex leiddu kóngar ok jarlar ok biskupar ok aðrir dýrir höfðingjar. Ok er peira hjúskapr helgaðr með bænahaldi ok allskonar prýði. Stóð petta brúðlaup yfir hálfan mánuð með allri blíðu ok allra handa gleði. (236)

[And in the evening the queen leads the maiden to bed, while kings and earls and bishops and other noble chieftains led Erex. And their marriage is consecrated with prayers and all kinds of ceremony. This wedding lasted over half a month with every gaiety and all kinds of good cheer.]

Next to omission, the Norse translator avoids Chrétien's heart-eyes imagery through a reformulation of the scene, as is exemplified in the onset of the 'prisonnier d'amour topos' in Yvain, quoted at the beginning of this chapter. It is through the lady's image, beheld from a tiny window, that the knight becomes a captive of love, as he is 'struck by love through the eyes into the heart':

son cuer en maine s'anemie,

s'aimme la rien qui plus le het.

Bien a vangiee, et si nel set, la dame la mort son seignor; vangence en a feite greignor; 
quë ele panre n'an seüst,

s 'Amors vangiee ne l'eüst,

qui si dolcemant le requiert

que par les ialz el cuer le fiert;

et cist $\cos$ a plus grant duree

que cos de lance ne d' espee':

cos d'espee garist et sainne

molt tost, des que mires i painne;

et la plaie d' Amors anpire

qant ele est plus pres de son mire.

Cele plaie a mes sire Yvains,

dom il ne sera jamés sains,

qu'Amors s'est tote a lui randue. (1364-81, my emphasis)

[his enemy has led away his heart,

and he loved the creature who most hates him.

The lady, although she doesn't know it,

has fully avenged the death of her husband;

she has taken greater vengeance than she could have imagined,

had love not avenged her,

who assailed him so gently,

striking through the eyes into the heart;

and this blow is more enduring

than any blow from lance or sword:

a sword wound is healed and cured 
as soon as a doctor sees to it;

but the wound of love grows worse

when it is nearest to its doctor.

My lord Yvain has suffered this hurt,

from which he'll never be healed,

for Love had completely overwhelmed him.]

Íven likewise admires the lady through the window, but due to the omission of much of Chrétien's 'prisoner of love' imagery and of his long digression on Amor's blow and the wound of Love (that runs for twenty-seven more lines in Yvain), the episode is transformed considerably. Cook demonstrates that the Norse translator of Marie de France's Lais systematically omits the figure of Amor. In 'Concepts of Love', he notes that although 'it may be that the Old Norse translator was unfamiliar with Love as a personified figure who shoots arrows at prospective lovers' and therefore omits the image of Amor, he deems it more likely that the translator 'does so deliberately, not because he fails to understand the text and the ideas behind them, but because he prefers, with his audience in mind, to present these ideas in a more straightforward fashion'. ${ }^{299}$ However, the alterations do not appear to be exclusively for the sake of simplification or brevity. The text describes Íven watching her:

Ok pví meir lystaði hann at sjá hana ok elskaði hana af öllum hug ok vildi gjarna tala við hana ok svá mikla ást hafði hann á henna at heldr vildi hann deyja par en tala eigi nokkut við hana ok freista ef hann mætti fá hennar ást. Í pessu kemr jungfrúin sú gangandi er hann varðveitti ok sá hann ihuga fullan ok ástbundinn sem hann vissi eigi hvat hann vildi.

\footnotetext{
${ }^{299}$ Cook, 'Concepts of Love', 67, 77.
} 
Hún mælti hann: 'Hvat hefir pú í lífi pínu?'

'Pann hug’, sagði hann, ‘sem mér vel líkar vel'. (52, my emphasis)

[And he desired to see her all the more and he loved her with all his mind and he very much wanted to speak with her and he felt such great love for her that he would rather die there than not speak to her and try to obtain her love. In this moment the young woman who took care of him [Lúneta] came walking in and saw him lost in thought and in the bonds of love as though he did not know what he wanted.

She spoke to him: 'What are you pondering?'

'A thought', he said, ' which pleases me greatly'.] $]^{300}$

Unlike the French knight, Íven is not struck through the eyes by the arrow of love into the heart, but is described as 'ástbundinn' (52) (in the bonds of love). In this representation, love is presented as a mental affliction as the knight is lost in thought (hann elskaði hana af öllum hug; íhuga fullan; Pann hug, 52). The Norse translation does not mention the wound of Love, so elaborately digressed upon in Yvain, through which love fills Yvain's heart and completely overwhelms him. ${ }^{301}$

\footnotetext{
${ }^{300}$ I have slightly amended Kalinke's translation here to call attention to the depiction of the mental state involved when being in the thralls of love (ástbundinn).

${ }^{301}$ The sense of embodiment that is present in the French passage, however, may still be reflected in 'Hvat hefir pú í lífi pínu?', which literally translates 'What do you have in your life?'. When we consider 'liff's earlier meaning of 'body' in addition to 'life', the Old Norse passage can be interpreted here to signify that 'a thought came into Íven's body'. 'Lif' is ascribed the meaning of 'body' especially in the context of (love) sickness and related bodily processes, see entry 7 for 'líf' (body) in Ordbog over det norrøne prosasprog/A Dictionary of Old Norse Prose (Copenhagen: Arnamagnæanske commission/Arnamagnæan Commission, 1983-), retrieved from https://onp.ku.dk/. Hoerra Ivan contains neither the 'prisonner of love'-motif, nor Ivan being 'struck by the arrow of love'.
} 
The last two lines in the passage quoted above correspond to lines 1552-54 in Yvain, where Chrétien's main storyline continues after having digressed on both Amor (1382-1409, 1511-51) and Nature (1432-1510), both of which are omitted in Ívens saga. Whereas the French Lunete asks the knight 'what sort of day he has had' ('Mes sire Yvain,/ quell siegle avez vos hui eüs'), which the knight considers 'greatly pleasing' because he beheld the lady's image through the window ('Tel', fet il, 'qui molt a pleu'), the Old Norse translator seems to have reframed Lunete's question to underline the cognitive process involved in falling in love, as the knight contemplates her image and is lost in reverie. ${ }^{302}$ Although this interpretation would correspond to a more native rendition of the mind as the seat of perception - as is attested, for example, by the representation of Óðinn's ravens Huginn and Munnin in Grímnismál-we need to consider textual mobility as well when it comes to these alterations and the large numbers of lines missing that follow upon them. ${ }^{303}$

Another example of the reformulation of an image of intercorporeal exchange, this time unconcerned with love, but with bravery, may be found in the Old Norse-Icelandic rendition of Yvain's fight against the pillaging Count Alier and his men (see Appendix, Synopsis, episode IV). Yvain decides to join the fight and fights so bravely that he inspires others around him:

\footnotetext{
302 Íven's reverie is much like Parceval's when he sees the duck's blood drops in the snow: 'Ok sem hann sá pessa hluti, nyfallinn snjó ok it rauðasta blóð, pá kom honum i hug at slíkkr litr var í andliti Blankiflúr, unnustu hans, ok var $<$ hann $>$ pat nú svá mjök hugsandi, at hann var öllu öđru gleymandi. Hann gáði enskis annars en sjá hér á. Svá var hann petta mjök íhugandi, ok sva tók hann pá mjök at unna, at ekki mátti hann pá annat kunna.' (Parcevals saga, ed. Kirsten Wolf and trans. Helen Maclean, in Norse Romance, ed. Marianne E. Kalinke, vol. 2: The Knights of the Round Table, Arthurian Archives V. Cambridge, UK: D.S. Brewer, 1999, 103-216, at p. 160, my emphasis) (And when he saw these things, the newly fallen snow and the very red blood, then it came into his mind that such colouring was in the complexion of Blankiflúr, his beloved, and on that so deeply did he reflect that nothing else did he recollect. He cared to do nothing other than to gaze on this. So deeply did he meditate, and so deeply did he then begin to adore, that he was powerless to comprehend anything more.) (my emphasis).

${ }^{303}$ This representation in Grimnismál is further elaborated on in footnote 240 of this study.
} 
Et cil qui avoec lui estoient,

por lui grant hardemant prenoient;

que tex a povre cuer et lasche,

quant il voit c'uns prodon entasche,

devant lui tote une besoingne,

que maintenant honte et vergoingne,

li cort sus, et si giete fors,

le povre cuer qu'il a el cors,

si li done sostenemant,

cuer de prodome et hardemant. (3175-84)

[Those who were with him

found courage in his example;

for a man with a poor and timid heart,

when he sees a brave man undertake

a bold deed in front of his very eyes,

will be overcome at once with disgrace

and shame, and will cast out

the weak heart within his body

and take on steadfastness,

bravery, and a good man's heart.] 
In this passage, the eyes are again presented as the conduits through which a change in emotional state is brought about. The image of bravery that is presented to the eyes inspires Yvain's companions to literally take heart.

Although roughly the same message is conveyed in Ívens saga, the specific role assigned to sight and the eyes as the mediums through which 'a change of heart' comes about is not rendered in the Norse translation. Íven fights so bravely that: 'peir er honum fylgðu dirfðuz nú af hans hreysti ok riddaraskap ok riðu vel fram ok djarfliga' (70) (those who accompanied him now grew daring because of his valour and chivalry, and charged forward boldly.) What is more, the image of a heart physically leaving the body in order to be replaced by a better one has also been lost in translation. This brings the reader back to the beginning of our comparison of heart-imagery, which spoke of a 'travelling heart': a heart that can leave the body and return to it.

\section{The Itinerant Heart Motif}

Brault refers to this notion of the heart moving in and out of the body as the 'itinerant heart' ${ }^{304}$ He shows it to be a frequently deployed motif in Chrétien's romances. For one, it comes about in the form of a ritual exchange of hearts through which the hearts of two lovers may be fused as one, making them susceptible to each other's sensations. More frequent is the image of the heart going back and forth between lovers:

The lover's heart may abandon itself, be given, imprisoned, loaned, lost, placed (in someone), promised, stolen, or taken back forcefully. "Having someone's heart" or the heart "being in someone else's power" or "belonging to someone else" means

\footnotetext{
304 'Chrétien de Troyes' Lancelot', 144. See also, Høystad, A History of the Heart, 126-28.
} 
quite literally that the body is forced to exist without this vital organ, living on only in the hope of re-joining it. ${ }^{305}$

The latter is the case when Yvain leaves Laudine to spruce up his reputation as a knight (see Appendix, Synopsis, episode III). Having lived in the service of love for too long, Yvain is encouraged by Gauvain to join Arthur and his party on their tournaments. In an attempt to uphold both his duties as a knight and as a lover, Yvain lends his body to chivalric adventure, but leaves his heart behind with his beloved:

Mes sire Yvains molt a enviz

est de s'amie departiz,

ensi que li cuers ne se muet.

Li rois le cors mener an puet

mes del cuer n'en manra il point

car si se tient et si se joint

au cuer celi qui se remaint

qu'il n'a pooir quë il l'en maint;

des que li cors est sanz le cuer

don ne puet il estre a nul fuer;

et se li cors sanz le cuer vit

tel mervoille nus hom ne vit.

Ceste mervoille est avenue,

que il a la vie retenue

sanz le cuer, qui estre i soloit

\footnotetext{
305 Ibid. 145.
} 
que plus siudre ne le voloit.

Li cuers a boene remenance,

et li cors vit en esperance

de retorner au cuer arriere'. (2643-61)

[My lord Yvain left his lady

so reluctantly

that his heart stayed behind.

The king could take his body with him,

but there was no way he could have the heart,

because she who remained behind

held and clung so tightly to that heart

that he had no power to take it with him;

once the body is without the heart,

it cannot possibly stay alive,

and if a body ever lived on without its heart,

no man had ever seen such a miracle before.

Yet now this miracle happened,

for Yvain remained alive without

his heart, which used to be in his body,

but did not wish to accompany it.

The heart was well kept, and the body lived in hope

of rejoining the heart.] 
Not only is this passage the most detailed example of the itinerant heart motif in Yvain, its symbolism, moreover, greatly contributes to understanding the armes/amours predicament on which Chrétien's entire plot builds. That the knight cannot live (on) without his lady suddenly takes on a rather literal form. This physical image of a body that is forced to exist without its vital organ may not have been compatible with the Old Norse-Icelandic conventions and tastes for the representation of love, which, as we have seen in this chapter, present love a predominantly mental form. This may explain why the entire passage has been omitted in Ívens saga. ${ }^{306}$

When Yvain fails to return to his lady before the agreed-upon deadline, the audience learns that Laudine has reciprocally given her heart to the knight. Enraged that Yvain did not uphold his promise, her maid Lunete now accuses him of having stolen her lady's heart:

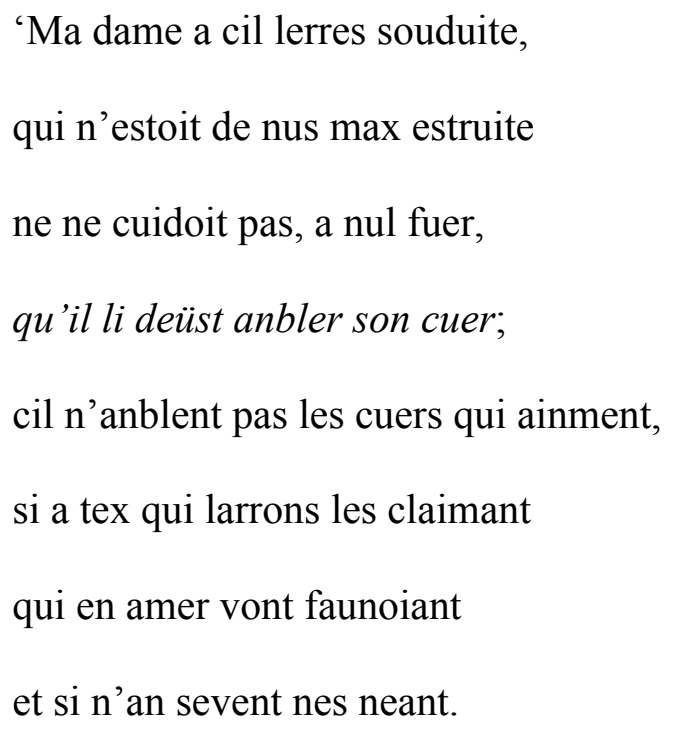

\footnotetext{
${ }^{306}$ The entire passage is is likewise omitted in Ywain and Gawain. Note that Harra Ivan contains a rather faithful rendition of this motif (2057-66). Although 'a lover's image' is repeatedly 'held in the mind' (hugha) in the Old Swedish poem (196-97; 3827-28; 6175-76), it adopts the extensive image of 'the heart residing in another's body' of its French source (2057-66).
} 
le tient chier, et si le raporte.

Mes sire Yvains la dame a morte

qu ele cuidoit qu'il li gardast

son cuer, et si li raportast,

einçois que fust passez li anz'. (2729-49, my emphasis)

['This thief has seduced my lady,

who had not experienced such evil

and could never have believed

that he would steal her heart.

Those who love truly don't steal hearts,

but there are those who call them thieves,

while they themselves only pretend to love

and in reality know nothing about it.

but the true lover cherishes his lady's heart

wherever he goes, and returns it to her.

Yvain has dealt my lady a mortal blow,

for she thought he would keep

her heart and bring it back to her

before the year had passed'.]

In Ívens saga, it likewise remains to be seen whether the knight's intentions are honourable or false, but instead of being accused of taking the perhaps too literal image of the heart, Yvain 
is reproached for stealing the somewhat more general and less physical image of love instead, thereby by-passing the itinerant heart motif:

'Mín frú ætlaði pik heilhugaðan, ok kom henni pat aldri í hug, at pú mundir stela ást hennar ok svíkja hana (68, my emphasis)

['My lady thought you were sincere, and it never occurred to her that you would steal her love and betray her'. $]^{307}$

Both Erex saga and Parcevals saga provide further text examples that suggest a more systematic mediation of the itinerant heart motif on the part of the translator(s). ${ }^{308}$ Chrétien applies the same imagery to his description of the falling in love of Erec and Enide on the road to Arthur's court. The reciprocity of their love is reflected in the metaphor of stealing each other's hearts:

De l'esgarder ne puet preu faire:

quant plus l'esgarde et plus li plest

an li esgarder se refet;

molt remire son chief le blont, ses ialz rianz et son cler front,

\footnotetext{
${ }^{307}$ In Hoerra Ivan the knight is likewise made out for a thief, but is not rebuked for stealing the lady's heart. Instead, it is stated that 'she was devoted to you in her heart' ('hon varper pik aldrigh af hiætæ hul', 2149). The metaphor is omitted in its entirety in Ywain and Gawain.

${ }^{308}$ Likewise consider the omission in Old Norse of 'stealing away a heart' (Erec et Enide, lines 6692-93) and of 'pulling out a heart with the lips through kisses' (Perceval, lines 5848-51).
} 
le nes et la face et la boche

don granz dolçors au cuer li toche.

mes ne remire mie mains

la dameisele le vasal

de boen voel et de cuer leal

qu'il feisoit li par contançon.

N'an preïssent pas reançon

li uns de l'autre regarder.

Li uns a l'autre son cuer anble. (1466-94, my emphasis)

[He could not gaze at her enough, the more he looked at her the more she pleased him ... Looking at her restored and delighted him; he kept looking at her blonde hair, her laughing eyes and unclouded brow, her nose and face and mouth and from this a great affection touched his heart. . . But the damsel, for her part, looked at the knight no less than he looked at her, with favourable eye and loyal heart, in eager emulation. They would not have accepted a ransom to leave off looking at one another, each of them stole the other's heart.] (56)

In addition to the itinerant heart motif, this passage is also reflective of the heart-eyes motif; a heart attended to by the eyes. 'The way to a man's heart is through his eyes', would be a fitting expression according to Chrétien. And the same applies for Enide. All along the long way to Cardigan they keep throwing glances at each other.

Both motifs have been rescripted in Erex saga. Accompanied by a retinue of knights, Erex and Evida depart straight for Arthur's court after the sparrow hawk contest. The Old 
Norse equivalent of their falling in love has been cut out and moved forward to be inserted at the moment when Erex first meets Evida at her father's lodging, before the sparrow hawk contest:

Ok pegar feldi hann allan sinn elskuhug til hennar. En er hún sá Erex, pá feldi hún allan sinn elskuhuga til hans, ok pótti pó undarligt, er hún skyldi kunna at elska ókunnan mann. Stóð nú hvárt ok horfði á annat. (226, my emphasis)

[At once he fell very much in love with her. And when she saw Erex, she fell very much in love with him, yet she thought it strange that she should be able to love a stranger. Each stood now and looked at the other.]

Although Erex saga does relate how both lovers could not stop looking at each other, there is no sense of them exchanging hearts or stealing each other's hearts in the process of falling in love. The incorporation of Evida's affirmation of Erec's love at this point in the narrative goes against the conventions of courtly love. Erex has not performed a single act of prowess or chivalry up to that point. Although this reformulation of the scene allows for a circumvention of Chrétien's heart-imagery, it seems to have left the Old Norse translator with the problem of having to explain Evida's all too sudden infatuation ('yet she thought it strange that she should be able to love a stranger').

\section{Conclusion}

As we have seen in the discussion above, representations of a 'feeling' heart are rare in traditional Old Norse-Icelandic literature, which pays little attention to the emotional states 
and inner life of its characters. The heart was traditionally not portrayed as a symbol for (idealised) love, but features more frequently as the seat of cognition and courage.

Considering these vastly deviating literary conventions for the representation of the heart and its metaphorical dimensions, Ívens saga reproduces surprisingly much of the imagery in Yvain deployed to portray interior feeling. While not refuting the overall reduction and occasional omission of these elaborate models of interiority that has often been assigned for Ívens saga, the addition of hugr or hugr-related lexis in such imagery reveals a level of engagement that goes beyond the mere excision of overly descriptive and metaphorical language and reflects just as much an investment on the part of the Norse translator to 'fix' or smooth over any incompatibilities between the two literary traditions in their representation of love, in order to convey Chrétien's imagery as closely as possible. This chapter reveals a more meticulous mediation of French matters of the heart in making the perhaps unfamiliar profile of cuer and its different tropes and motifs intelligible to Nordic audiences. A comparison of the representation of the heart and its love-related imagery in Yvain and Ívens saga has revealed the following signs of engagement on the part of the Norse translator with Yvain's emotive script.

Firstly, an examination of the heart as a personhood construct reveals the translator's engagement with its semantic profile. Whenever Chrétien's heart-imagery is translated, Old French cuer is often rendered a dual representation, in which love-related emotions are presented as agitations of the mind (hugr) that may be perceived to reside in the heart (hjarta), but reveals a separation in function and faculty. Particularly those images that are provided a rather literal representation in Yvain, such as being in possession of or having (control over) a lover's heart, are transformed to underline the cognitive processes involved in Ívens saga, suggesting that hjarta was traditionally solely attributed a vivifying function. 
Secondly, an examination of the metaphorical conceptions of the heart reveals the translator's engagement with the perception model that such imagery in Yvain is reflective of. In the French poem, such representations present a heart that receives information through the mediation of the senses. Calogrenant's request for his listeners' attention before he is about to begin his tale best showcases such a model. His visualisation of the ears as 'the path and channel' (Yvain, 1566) through which his words travel to the heart has been connected to the medieval model of memory as the storehouse of affective rumination. This elaborate audite topos has been adapted with remarkable faithfulness by the Norse translator when we consider that Norse translators of French romances have been ascribed the general tendency of reducing such lengthy and descriptive exposés. However, where in Yvain understanding (entendre) takes place in the heart, in Ívens saga understanding (skilja) is repeatedly named as a faculty of the mind. Due to the omission of the specific imagery that present the ears as the trajectories through which external sensations enter the heart, hugr deviates in profile from memoria in this passage. Any such imagery of the senses as doorways through which sensations enter the heart is absent in Ívens saga, either through the specific omission of the senses, through the overall reformulation of such metaphors, or through complete omission of the trope. Similar signs of engagement come to the fore when studying the adoption of Chrétien's heart-eyes motif. In their Old Norse renditions, the eyes do not feature as the channels through which love comes about in the heart. The classical image of Amor's arrow inflicting the wound of Love is omitted. Similarly the image of the beloved does not strike through Íven's eyes into the heart. Instead, a thought is described to enter his mind.

Under particular negotiation in the act of making Chrétien's conceptualisations of love meaningful for Nordic audiences seems to be the notion of the heart itself moving in and out of the body through such doorways. The last section has zoomed in on the reproduction of this so-called itinerant heart motif. Whereas the Norse translator's engagement with culture- 
specific cuer and Yvain's perception model reveal a more systematic mediation of these representations in Yvain's emotive script—-transforming such conceptions by marrying them with native representations, while simultaneously retaining part of their imagery-an examination of the translator's engagement with the image of a heart travelling between bodies chiefly reveals a rejection of this motif, either through complete transformation or, most frequently, through omission. The decidedly concrete and perhaps too literal descriptions ascribed by Chrétien to the intercorporeal images of 'exchanging hearts' or 'stealing someone's heart' may not have met the horizon of feeling of Nordic audiences, who may have favoured a more straightforward representation.

However, the alterations assigned do not appear to be for the sake of simplification or brevity alone. Sarah Brazil, who has examined the materiality of metaphor in a fifteenthcentury Middle English devotional treatise on the heart, notes 'in pausing over such metaphors contemporary readers often privilege the figurative above the literal, or the message above the medium', seeing functionality solely in the literary ornamentation that such imagery brings. ${ }^{309}$ The specific engagement assigned for the Norse translator with cuer's profile and its relation to the senses makes it conceivable that, in addition to a divergence between emotive scripts regarding the deployment of metaphorical ornamentation, the metaphysical dimensions of Chrétien's heart conceptualisations may have clashed with Nordic psychologies, which may have included deviating views on the human sensorium. In 'The Social Life of the Senses', historian Chris Woolgar writes:

Any discussion of the senses in medieval Europe must have as its starting point a recognition that, as at any other period, contemporary understanding of the operation

\footnotetext{
309 'The Materiality of Metaphors: Why the Affectus Needs Shoes in The Doctrine of the Hert', in Emotion and Medieval Textual Media, ed. Mary C. Flannery (Turnhout: Brepols, 2018), 177-93, at 177.
} 
of the human sensorium was culturally determined. While there were similar attitudes across Europe, derived from a common intellectual heritage, beliefs and practices varied from country to country, social group to social group, and chronologically, ${ }^{310}$

While these words certainly validate a comparative examination of heart concepts and sensory models in Yvain and Ívens saga, they at the same time demonstrate the inherent complexity in drawing cultural conclusions from such a comparison. As Woolgar rightly points out, alternative (literary) representations of such imagery can be explained on multiple levels and may be of a geographical, socio-cultural and/or diachronic nature. The exact factors to have motivated the reformulations assigned in this chapter will thus remain unknown to us. There may have been a distinct Nordic understanding of the operations of the heart and the senses that differed from Continental beliefs. Although research in this area is limited, Margaret Clunies Ross has argued that the understanding of the senses in medieval Scandinavia was not as well developed as it was in Continental culture and was systemised to a lesser extant. ${ }^{311}$

The correspondences assigned in the way Chrétien's heart concepts were engaged with, not just for Ívens saga, but also for those translations that were presumably adopted for the same reading community-like Strengleikar, Parcevals saga, Erex saga-strengthen the notion that these adjustments are not random or accidental, but were made consciously and therefore may carry cultural and historical meaning. Although we cannot establish with absolute certainty that it was the Norwegian translator and audience who prompted these alterations, it is indeed, as Barnes points out, more difficult to conceive that different

\footnotetext{
${ }^{310}$ Woolgar, 'The Social Life of the Senses', 23.

311 “'Fimm líkamsins vit”: The Development of a New Lexical Set in Early Norse Christian Literature.' Arkiv för nordisk filologi 102 (1987), 197-206, at 197-99.
} 
Icelandic scribes working on different texts in different periods would have made the same modifications. $^{312}$

312 'The Riddarasögur: A Medieval Exercise in Translation', Saga Book of the Viking Society for Northern Research 19 (1974), 403-41, 413. 


\title{
CHAPTER TWO: MEDIATING PERFORMATIVE ACTION AND SPEECH
}

\author{
Reconciling Lovers in Yvain and Iwein $^{313}$
}

The ending to Yvain sees the eponymous knight reunited with his lady. As we have seen in chapter one, the story addresses the tensions between the claims of love and knighthood. Yvain, as a young knight, personifies this problem, as he is still learning how to balance his pursuit of marital bliss and of individual glory. Although he obtains his bride's permission to join Arthur's knights on their round of tournaments, he fails to uphold his promise to return to her witin the year. This violation against love causes Yvain to lose Laudine's favour and he is sent away from court. However, after a series of adventures that mark a maturation process, Yvain atones for his mistake at the end of the romance by falling on his knees before her. Dramatic irony is at play as Yvain appears before Laudine as the Knight with the Lion, whose identity remains secret to the lady, but not to the audience. Trapped by her promise to Lunete to do everything in her power to reconcile this unhappy knight with his lady, Laudine now has no choice but to forgive Yvain and accept him again as her husband.

Tony Hunt has remarked on this scene: '[1]ike so much of Yvain, this ending is designed to produce debate'. ${ }^{314}$ Like Laudine at the end of Yvain, he notes, audiences must decide for themselves how to respond to Yvain's offence against love. This debate also seems to have taken place in the process of adapting the story to a new German audience. Like Chrétien de Troyes's Yvain, Hartmann von Aue's Iwein describes the reunion of the knight and his lady in much detail. However, the couple's reconciliation comes about in a

\footnotetext{
${ }^{313}$ Parts of this chapter have been published as Vondenhoff, 'The Performative Function of the Socialised Body: Falling to One's Knees in Hartmann's Iwein and Erec', Arthuriana 29.4 (2019), 8-27.

${ }^{314}$ Chrétien de Troyes: Yvain (Le chevalier au lion), Critical Guides to French Texts 55 (London: Grant \& Cutler, 1986), 82.
} 
significantly different manner in Iwein's so-called B-ending. Where the story of Yvain is brought to a conclusion with the knight being pardoned by his lady at her feet, this Middle High German adaptation contains additional verses in which the lady Laudîne falls to her knees as well and is likewise pardoned by her husband.

Gestures such as the knee-fall fulfilled a significant role in the scripting of emotion in courtly romance. ${ }^{315}$ By supplementing — or even entirely replacing—-speech, these narrative signs reflected upon the relationships of characters, not just on a ceremonial, but also on an emotional level. Gestures fulfill a communicative function in medieval romance in that they give expression to the feelings of characters and their attitudes towards each other. In light of this, this chapter examines Laudîne's knee-fall as a performative action that alters the image of love presented in Yvain. In the coming sections, I discuss the variant versions of the reconciliation scene in more detail. Specifically, I examine how the German B-redaction adjusts Yvain's emotive script for the successful resolution of the love dilemma in the story, revealing a divergence in the horizon of feeling of its targeted audience.

Approaching Laudîne's knee-fall and the altered love ideal as a reception-motivated adjustment of Yvain's emotive script invites further comparison. This chapter therefore first discusses emotive reformulations of a related nature elsewhere in Iwein that may be argued to foreshadow the altered reconciliation in the B-ending. Secondly, it presents a textual comparison with Hartmann's Erec, a text that, as this chapter will show, reveals notable similarities with Iwein's B-ending in its reformulation of the image of love of its French source as well as in the scripting of performative gesture and speech. Before doing so, this chapter looks in more detail at the function of gestures in medieval society and literature and their relation to emotion.

\footnotetext{
${ }^{315}$ See for instance Stephen C. Jaeger, The Origins of Courtliness: Civilizing Trends and the Formation of Courtly Ideals 939-1210 (Philadelphia, PA: University of Pennsylvania Press, 1985); and John Burrow, Gestures and Looks in Medieval Narrative (Cambridge: Cambridge University Press, 2002).
} 


\section{Gestures in Medieval Society and Literature}

It is generally assumed that medieval European society attached high importance to gestures. In La civilisation de l'Occident médiéval, prominent medievalist Jacques Le Goff speaks of 'une civilisation du geste' ('a civilization of the gesture'). In this work, he chiefly addresses the ceremonial value of social, and in particular, legal gestures for medieval society. ${ }^{316}$ Exchanging kisses or the joining of hands, for instance, played an essential part in ceremonies of homage and fealty and meant more than words. Drawing on Le Goff's characterisation of medieval society, Jean-Claude Schmitt has studied the symbolic significance of gesture in historical as well as literary sources of the period. In La raison des gestes dans l'Occident médiéval, he shows how such physical acts likewise became ritualised in political and religious domains and, over time, came to serve an emotive function within those domains, as well as through their representation in art and literature. ${ }^{317}$

In his analysis of such ritualised exchanges in a wide range of medieval narratives, John Burrow shows both studies to be vital when it comes to the examination of gestures in relation to these texts and their reception, as they call attention to the weight of gestures and their significance for the medieval interpreter. In Gestures and Looks, Burrow emphasises that the modern reader is inclined to underestimate the weight of gestures in medieval literature, which may strike them as emotionally excessive and forced instead. He moreover draws attention to the possibility that the meaning and expression of such non-verbal signs may no

\footnotetext{
${ }^{316}$ La civilisation de l'Occident médiéval (Paris: Arthaud, 1964), xi. Translated in English as Medieval Civilisation 400-1500, trans. Julia Barrow (Oxford/Cambridge/Massachusetts: Basil Blackwell, 1988).

${ }^{317}$ Jean-Claude Schmitt, La raison des gestes dans l'Occident médiéval (Paris: Bibliothèque des Histoires, Gallimard, 1990). For further studies that address the importance of gestures in medieval society gestures and literature see Jan Nicholaas Bremmer, Herman Willem Roodenburg, eds, A Cultural History of Gesture: From Antiquity to Present Day (Cambridge: Polity Press, 1993); Guillemette Bolens, The Style of Gestures: Embodiment and Cognition in Literary Narrative (Baltimore: John Hopkins University Press, 2012); Dietmar
} Peil, Die Gebärde bei Chrétien, Hartmann und Wolfram, Medium Aevum: Philologische Studien 28 (München: Wilhelm Fink, 1975). 
longer be recognisable to us, since the conventions governing their use may have changed over time:

Some of the more formal gestures, such as bowing and kneeling, are now largely obsolete in the West; so we are inclined to underestimate their significance and force, and also fail to appreciate the subtleties that may attend their performance: in medieval Europe, as in modern Japan, an underperformed bow does not pass unnoticed. ${ }^{318}$

Although called into existence for their ceremonial use, with time such formal gestures, such as the knee-fall, became rules of conduct as part of a civilizing movement in the European courts. In The Origins of Courtliness, Jaeger shows that, with the blossoming of courtly literature in the second half of the twelfth century, these rules of conduct developed into a 'poetics of conduct' as courtly romance became 'an 'eloquent testimony to the effects of this civilising force': Court life produced 'an intense refinement of sentiment and emotion, the ability to detect subtle shades of meaning and expressions of intention and sentiment in the most minute gestures. ${ }^{319}$ The bodily actions of the characters in these romances were thus not just randomly assigned for their dramatic value, but were, according to Jaeger, deliberately scripted to communicate chivalric ideals and emotional codes of contemporary court life, ascribing them an important signifying function. ${ }^{320}$

Indeed, semiotics was not born with Charles Sanders Peirce. A theory of signs already existed within medieval scholastic tradition, with Augustine as a main authority on the subject. In Book Two of his De Doctrina Christiana, Augustine addresses the nature and function of given signs (data) as intentionally produced signals that originate from an urge to

\footnotetext{
${ }^{318}$ Burrow, Gestures and Looks, 6.

${ }^{319}$ Jaeger, The Origins of Courtliness, see Introduction, at 13, and Conclusion at 261.

${ }^{320}$ Ibid. 258.
} 
communicate thoughts and feelings. He exemplifies the category of given signs with gestures, such as a bow or a nod, that reach the eyes of the receiver in the form of verba visibilia (visible words). ${ }^{321}$

Augustine's discussion of this form of outer emotion is what historical anthropologist Monique Scheer refers to as 'doing emotion,' which she distinguishes from the nonsignifying, inner experience of 'having emotion. ${ }^{, 322}$ She notes, however, that one does not necessarily exclude the other. The experience of 'doing emotion' is therefore not fake or insincere, but its demonstrative nature highlights its performative function. Scheer, in fact, closely relates outer emotion with the experience of feelings. Intentional or not, practicing emotion through bodily actions can generate actual feelings, whether in the person doing the signifying or in the beholder of such expressive behaviour.

Although both Augustine and Scheer discuss the signifying function of emotion for actual human beings, the same can be argued for literary characters. Just like real people 'do' emotions through socially shaped bodily practices, fictional characters perform emotion shaped by literary convention. ${ }^{323}$ Literary expressive behaviour, in fact, always signifies to the receiver, since, unlike real people, the somatic responses of fictional characters are never

\footnotetext{
${ }^{321}$ Augustine, De Doctrina Christiana, Book 2, trans. Roger Green (Oxford: Clarendon Press, 1995), 5. For further discussion see Burrow, Gestures and Looks, 1-4.

322 'Feeling Faith: The Cultural Practice of Religious Emotions in Nineteenth-Century German Methodism,' in Out of the Tower: Essays on Culture and Everyday Life, ed. Monique Scheer et al. (Tübingen: TVV, 2013), 217-47. Scheer builds on anthropological studies in drawing the distinction between the having and doing of emotion. She follows Peter and Carol Stearns' 'emotionology' in investigating not the inner experience of the emotion itself, but the trigger that sets off emotion. This doing of emotion has also widely been examined in sociological studies with the help of heuristic concepts, such as Arlie Hochschild's 'feeling rules' and 'emotional management.' For more information see Scheer, 'Feeling Faith,' 221-24.

${ }^{323}$ As has, for example, been argued by Kathryn Starkey in 'Performative Emotion and the Politics of Gender in the Nibelungenlied', in Women and Medieval Epic: Gender, Genre and the Limits of Epic Masculinity, ed. Sara S. Poor and Jane K. Schulman (New York: Palgrave Macmillan, 2007), 253-71. Starkey addresses the signifying function of a smile in German epic and argues it serves as 'a political and performative gesture' in communicating emotion (at 255).
} 
involuntary, as they do not communicate intentions beyond what the text implies. Since these gestures are only accessible through, and in context of, the narrative that records them, they are entirely open to an examination of their performative function, ${ }^{324}$ provided we take into account, as is noted by Schmitt, '(the weight of) the vocabulary' that describes them and 'the ideologies that intrude between the gestures, the texts, and ourselves'. ${ }^{325}$

Following this approach, the next two sections will shed light on both the semantic and textual context of the 'knee-fall', before we move unto the textual comparison. The first will look into more detail at the Old French and Middle High German vocabulary for those gestures that involve kneeling actions in Chrétien and Hartmann's works and discuss what these narrative signs are believed to signal in chivalric romance. The second section that follows will give more information on the textual variants for Iwein.

\section{The Knee-Fall}

Although the lowering action of Yvain in the reconciliation scene is described as a more general 'falling at the feet' in Old French ([a] ses piez s'est lessiez cheoir/ mes sire Yvains, 6736-37), it has come to be addressed as a 'knee-fall' in the majority of the studies on the

\footnotetext{
324 'Performative' is understood here within Starkey's definition 'as changing the status of someone or something', thus altering the emotive exchange between characters by means of textual gestures and speech ('Brunhild's Smile: Emotion and the Politics of Gender in the Nibelungenlied', in Codierungen von Emotionen im Mittelalter/Emotions and Sensibilities in the Middle Ages, ed. Stephen C. Jaeger and Ingrid Kasten, Berlin: De Gruyter, 2003), 159-73. It is to be distinguished from 'performance', which the editors of Performing Emotions in Early Europe define as 'self-conscious emotion that is actualised and understood through a sustained set of acts, rituals and stylizations'(Philippa Maddern, Joanne McEwan, and Anne M. Scott, eds, Performing Emotions in Early Europe, Early European Research 11. Turnhout: Brepols, 2018, xiv). For a further differentiation between both terms see Andrew Parker, Eve Kosofsky Sedgwick, eds, Performativity and Performance (New York/London: Routledge, 1995).

325 'The Rationale of Gestures in the West', in A Cultural History of Gesture, ed. Jan Bremmer and Herman Roodenburg (Cambridge: Polity Press, 1991), 59-70, at 63.
} 
knight's prostration in this scene, perhaps as it is is implied that this gesture is carried out on one's knees. The depiction of the reconciliation scene in the miniature cycle of Bibliothèque Nationale, Paris, fr. 1433's indeed seems to suggest so (see Appendix, Images, image 1). In Images of Adventure, James A. Rushing Jr. argues that this miniature cycle represents an intermediate mode of pictorial narrative and may be considered as a reading aid. ${ }^{326}$ The final of BN fr. 1433's multipart miniatures portrays the reunion of the couple and in the upper register Yvain is depicted kneeling before Laudine, thus bringing both his adventures and the story to an end.

Both Peil and Burrow ascribe both genuflection and prostration the same social meaning in courtly romance. Burrow shows that all actions that involve bowing, kneeling and prostration signal a shift in the relationship of the characters involved as when, for example, benefits are sought or received: 'the general rule is that the more you lower your body, the more humbly you submit. Prostration marks the extreme form of such self-abasement. ${ }^{, 327}$ Peil likewise groups together the 'Knie- und Fußfall' for Chrétien's romances and considers both to signal 'Unterwerfung' (submission). ${ }^{328}$ Indeed, both bodily actions are interchangeably deployed in Chrétien's Yvain and Erec as the examples presented in this chapter will demonstrate, thus suggesting that genuflection and prostration may be interpreted as similar acts of submission in his narratives.

Both descriptions may also be found in Hartmann's adaptations. ${ }^{329}$ Laudîne's knee-fall has likewise come to be known as such through studies like Werner Schröder's Laudines

\footnotetext{
${ }^{326}$ Images of Adventure: Ywain in the Visual Arts (Philadelphia: University of Pennsylvania Press, 1995), 17879.

${ }^{327}$ Burrow, Gestures and Looks, 18.

${ }^{328}$ Peil, Die Gebärde bei Chrétien, Hartmann und Wolfram, 200.

${ }^{329}$ See for example my discussion of Enites Kniefall below.
} 
Kniefall und der Schluß von Hartmanns Iwein, ${ }^{330}$ while, in fact, the Middle High German reads: 'Dâ mit viel sî an sînen vuoz' (8198) (Thereupon she fell at his feet). Enite's submission to Erec, however, reads: 'bôt sich vür in an ir knie' (3995) (she knelt down on her knee before him). For convenience sake, this chapter will adhere to the term 'knee-fall', or 'kneeling' in general, in its discussion of gestures of this nature.

\section{Iwein's B-Redaction}

The verses containing Laudîne's knee-fall have given rise to an on-going philological discussion around their place in Iwein's text tradition. Although all critical editions of Iwein include the scene of Laudîne kneeling at Îwein's feet, there is no conclusive evidence that this passage belongs to the original configuration of Iwein, nor if it should be ascribed to Hartmann. This extended ending has only come down to us through the B-redaction. This redaction is based on one of the two earliest complete manuscripts which was dubbed 'Handschrift B' by nineteenth-century editor Karl Lachmann. ${ }^{331}$ Unlike 'Handschrift A' - the other earliest complete manuscript of Iwein - B contains fifty-two additional lines that reveal a focus on the female characters of the story and include Laudîne's knee-fall. ${ }^{332}$ In addition to the expanded reconciliation scene, these lines relate the marriage of Lûnet.

Iwein has a rich manuscript tradition. Of the sixteen complete manuscripts and seventeen fragments, A and B have generally been put forward as the oldest, though neither

\footnotetext{
${ }^{330}$ Laudines Kniefall und der Schluß von Hartmanns Iwein (Stuttgart: Steiner, 1997).

${ }^{331}$ Iwein: Der Riter mit dem Lewen, getihtet von den Hern Hartman Dienstman ze Ouwe, ed. George F. Benecke and Karl Lachmann (Berlin: G. Reimer, 1827).

${ }^{332}$ These lines also survive in dependant manuscripts $\mathrm{Ba}$ and $\mathrm{Bd}$ (contains only the onset of these lines). For an overview of the plus lines in B and the five substantial deviations from the A text see the introduction to Edwards's edition of Iwein in the Arthurian Archives series (Cambridge: D.S. Brewer, 2007), xxiv-xxv.
} 
seems likely to be Hartmann's autograph. ${ }^{333}$ Both are ascribed to the beginning of the second quarter of the thirteenth century. Some scholars favour the first third of the thirteenth century for $\mathrm{B}^{334}$ The normalisation of dialect features that has occurred in this manuscript, however, prevents scholars from reaching a general consensus as it complicates the process of assigning both date and provenance. ${ }^{335}$

Although the extra verses that do not have an equivalent in Chrétien's text have been the subject of much debate, scholars have not come to a consensus regarding their origin. They may have originated either during the composition of Iwein or, instead, were added only after the work was completed, presumably by the author himself, as suggested by editors Lachmann and George Benecke, who concluded that the lines fully correspond to Hartmann's use of language and style. ${ }^{336}$ Ludwig Wolff also put forward the theory that the lines might be a later addition by Hartmann himself. ${ }^{337}$ The alternative ending could therefore indicate the

${ }^{333}$ Although they have no external basis for dating, the Kremsmünster fragment V (Stiftbibliothek Kremsmünster, CC VI\275) and Prague fragments H (Prague, State and University Library, Fragm. Germ. 4 and Fragm. Germ. 16) are believed to be of similar date (Iwein, ed. and trans. Edwards, xxi).

${ }^{334}$ In his introduction to the facsimile of Iwein Handschrift B Heinrich Matthias Heinrichs expresses the belief that this manuscript was composed during Hartmann's lifetime, around 1200 and no later than 1220 (Iwein Handschrift B, Deutsche Texte in Handschriften 2, Köln: Böhlau Verlag, 1964, viii-ix). In the 1980s, Thomas Klein argued for an earlier dating of the text in 'Ermittlung, Darstellung und Deutung von der Handschriftenüberlieferung mittelhochdeutscher Epik', Deutsche Handschriften 1100-1400, Oxforder Kolloquium 1985, ed. Volker Honeman and Nigel F. Palmer (Tübingen: Niemeyer, 1988), 110-67, at 148-49. Likewise, Patrick McConeghy argues that the language of B most closely approximates the Alemannic dialect of the poet and places its ortographic style in the first decades of the thirteenth century, only a few years after the original. He believes A, whose language reflects the Middle High German spoken around Cologne, to stem from the middle of the thirteenth century (Hartmann von Aue: Iwein, xl). Although the lines that contain Laudîne's knee-fall are generally seen by scholars as an addition, these studies show that it is not inconceivable that the Bending is the earlier redaction, in which case A would be a reduction of $\mathrm{B}$.

${ }^{335}$ Iwein, ed. and trans. Edwards, xxii.

${ }^{336}$ See the introduction to Benecke and Lachmann's edition, Iwein: Der Riter mit dem Lewen, 3-8.

337 'Die Iwein-Handschriften in ihrem Verhältnis zueinander', in Festschrift Helmut de Boor (Tübingen: Niemeyer, 1966), 111-35; see also Wolff based on Benecke and Lachmann, eds, Iwein: Eine Erzählung von 
co-existence of two Iweins, either through a different redaction by Hartmann, as suggested by Emil Henrici, or by a different author with separate access to Chrétien's text, as proposed by Joachim Bumke. ${ }^{338}$ Werner Schröder argued that the scene should be seen as a later redaction of a contemporary of Hartmann, who was deeply immersed in Hartmann's work. ${ }^{339}$

The circulation of different versions of one story was not unusual for vernacular literature of the twelfth and early thirteenth century. ${ }^{340}$ In 'Manuscript versus Edition,' Evelyn Meyer argues against the Lachmann method, by challenging the notion of a stable transmission process of Iwein and the existence of a single lost original for the Middle High German poem. ${ }^{341}$ Instead, she follows Bumke in believing that 'manuscripts containing vernacular literature of the High Middle Ages are "unfeste Text[e]", full of differences that are the result of the cultural practices of the performance-oriented society, which savoured twist and turns in plots with which the audience was already familiar. ${ }^{, 32}$ In the introduction to his edition of Iwein, Cyril Edwards likewise notes that 'it was no doubt dissatisfaction with the Old French ending, whether on the part of Hartmann himself, his audience, or a redactor,

Hartmann von Aue, $7^{\text {th }}$ edn, 2 vols (Berlin: De Gruyter, 1968). The second volume to this edition contains a thorough description of all complete Iwein manuscripts.

${ }^{338}$ See Henrici's introduction to Iwein: Der Ritter mit dem Löwen, ed. Emil Henrici, Germanistische Handbibliothek 8 (Halle an der Saale: Verlag des Buchhandlung des Waisenhauses, 1891). Henrici suggests that Hartmann may have revised his story after copies of a first version had been made. Joachim Bumke, Die vier Fassungen der Nibelungenklage: Untersuchungen zur Überlieferungsgeschichte und Textkritik der höfischen Epik im 13. Jahrhundert, Quellen und Forschungen 8 (Berlin: De Gruyter, 1996), especially 33-42.

${ }^{339}$ Schröder, Laudines Kniefall, 5-7.

${ }^{340}$ The composition of vernacular stories was still largely oral and memorial until the end of the thirteenth century, when literary composition started shifting towards a written culture, see Joachim Bumke, 'Der unfeste Text, Überlegungen zur Überlieferungsgeschichte und Textkritik der höfischen Epik im 13. Jahrhundert,' in 'Aufführung' und 'Schrift' in Mittelalter und Früher Neuzeit, ed. Jan-Dirk Müller (Stuttgart: Weimar, 1996), $118-29$, at 127.

341 'Manuscript versus Edition: The Multiple Endings of Yvain/Iwein/Ywayne and their Gender Implications,' Amsterdamer Beiträge zur älteren Germanistik 67 (2011), 97-141, at 99.

${ }^{342}$ Meyer, 'Manuscript versus Edition, 97, citing Bumke, Die vier Fassungen, 118. 
which led to the major alterations to the B-redaction,' thus suggesting that Chrétien's ending did not suit the horizon of expectations of its new audience when it comes to the resolution of the love dilemma in the story. ${ }^{343}$ In particular, he puts forth the theory that the B-redaction is a response to female readership, possibly brought on by the popularity of Hartmann's Erec. ${ }^{344}$

Instead of viewing manuscript variants as corruptions, there is value to be found in their deviations when we consider their possible relation with audience-reception. They mark a shift in the readerly expectations and predilections of an audience. It is precisely these reception-generated alterations that this chapter means to highlight. The matter of whether these lines ultimately were part of a supposed original and/or written by Hartmann or not does not change the implications of the current study. The fact remains that an alternate Middle High German ending came into circulation sometime around Iwein's composition and that this variant redaction reveals the need to engage with and expand upon the emotive script provided by Chrétien for the successful reconciliation of the lovers within its new context.

Following Meyer and Edwards, this chapter also examines the possible influence Hartmann's Erec may have had on the alterations to Chrétien's ending. The second part of this chapter will therefore provide a textual comparison of the altered image of love assigned for Iwein with Hartmann's Erec, a text that reveals notable similarities in the deployment of performative gesture and speech ascribed to the female protagonist. A textual comparison of the representation of love in Yvain and Iwein will come first. This first part will look into

\footnotetext{
${ }^{343}$ Iwein, ed. and trans. Edwards, appendix, at 391. With this statement, Edwards is not only referring to the alterations made to the reconciliation scene, but also to the marriage of Lûnet.

${ }^{344}$ As such, Edwards deems it very likely that it was a reworking by Hartmann himself. He draws attention to a correspondence in the vocabulary and style employed by the B-author and that of Hartmann's Erec (Iwein, xxv). See also Ursula Kuttner, Das Erzählen des Erzählten: Eine Studie zum Stil in Hartmanns Erec und Iwein, Studien zur Germanistik, Anglistik und Komparatistik 70 (Bonn: Bouvier, 1978); and Erika Oh, Aufbau und Einzelszenen in Hartmanns von Aue höfischen Epen Erec und Iwein, PhD dissertation, University of Hamburg, 1972.
} 
more detail at how Laudîne's added knee-fall changes the codes of courtly love in Yvain's emotive script by connecting it to Hartmann's transformed development of the knight throughout Iwein.

\section{Individual Offence}

Interestingly, the altered reconciliation scene fits well with modifications of a related emotional nature elsewhere in Iwein - where the text runs parallel in both A and B - that likewise give evidence of a conscious reformulation of the image of love as presented in the French romance. ${ }^{345}$ One of these is Hartmann's transformation of the romance's Bildung of the knight. Where the French poem presents the reader with a protagonist who recognises his offence and learns from it, its German rewriting does not give evidence of such a maturation process until the very end. On multiple occasions, in fact, we find Îwein's responsibility for the separation of the couple being refuted, both by the narrator and by the knight himself as well as by other characters.

The first time that Hartmann plays down Îwein's fault in the separation is when the knight chances upon the Land of the Fountain again (Appendix, Synopsis, episode V). Having returned to the place at the origin of his misfortune, he is reminded of his loss and is overcome with grief. While he laments his sorrowful fate, a damsel imprisoned in a nearby chapel overhears his words and calls out to him. Although the knight does not know it, this damsel is in fact Lunet(e), Laudine's lady-in-waiting, who has been accused of treason against her lady for proposing the love-match with Yvain. What follows in Yvain is what can

\footnotetext{
${ }^{345}$ McConeghy comes to a similar conclusion after having studied the redrawing of the figure of Laudîne. He notes that: 'Hartmann has prepared the reader for her change of heart [regarding her contrition in the reconciliation scene, $\mathrm{CV}$ ] with the softening of her character in the beginning scenes' (Hartmann von Aue: Iwein, ed. and trans. McConeghy, xxxv).
} 
be seen as a competition for the award of 'most piteous.' The French knight and the girl, as Ojars Kratins notes, 'begin an argument which hyperbolically elevates the lover's grief [Yvain's] by contrasting it to the anxieties of the prisoner [Lunete's]. ${ }^{346}$

In Chrétien's story, both Yvain and Lunete advocate their own case. Yvain argues that Lunete's grief is joy and her suffering is bliss compared to his. Since having lost his lady's favour, he has experienced an abrupt change from joy to grief, and hence who is more miserable than the man who receives his heart's desire only to lose it again? Lunete counters this argument by contending that her misery must be greater, since at least the knight is free whereas her fate is sealed for she will be burned at the stake for her alleged treason (3565608). Not only her facing death, but, more importantly, the notion that she has to suffer as a result of false accusations makes her state more pitiful than Yvain's, whose suffering is entirely of his own doing. Somewhat ironically, it is the girl's innocence that seals Yvain's victory as 'most piteous' (3609-14). Since the girl is innocent, it can surely be proven in a trial by combat. He, however, is not blameless and therefore cannot be spared from his suffering. Yvain then offers to be the defender of Lunete's innocence, thereby indirectly absolving her from any blame in the failed marriage and taking it upon himself instead.

This somewhat remarkable scene, in which the knight and the maiden share their hardships through a crack in the wall, marks the moment of Yvain's contrition that will later prove to be the turning point in the knight's conduct. By contrasting Lunete's hardships to those of Yvain the conversation functions to appeal to the latter's conscience, as Yvain starts to come to terms with the fact that he has brought about his own downfall and needs to make amends for his transgression against Love. This insight is important for Yvain's growth as a

\footnotetext{
${ }^{346}$ The Dream of Chivalry: A Study of Chrétien de Troyes's Yvain and Hartmann von Aue's Iwein (Washington, D.C.: University Press of America, 1982), 128.
} 
knight throughout the second adventure cycle. ${ }^{347}$ The knight's show of contrition in the scene foreshadows his atonement and the eventual reconciliation with his bride, which comes to a climactic expression in the final episode of the romance.

In the final episode, Yvain returns to the land of the Fountain in the hope of reuniting with his wife. When the knight is brought before his lady, he immediately falls at her feet. Laudine, who does not yet know that the man who is kneeling before her is in fact her husband, initially acts sympathetically towards him. She swears an oath to Lunete to do everything in her power to help this man, whom she knows as the Knight with the Lion. When she learns the truth, however, she trembles with anger as she realizes she is now trapped by her pledge to forgive him: 'Or as tu esploitié molt bien!/ Or m'as tu molt an gré servie!' (6770-71) ('What a fine thing you've done!/ What a great way to serve me!'). Laudine's indignant rant forces Yvain to translate his gesture into words. Fearing the reconciliation might not come about now, he quickly pleads guilty:
'Dame, misericorde, doit an de pecheor avoir.
Conparé ai mon nonsavoir, et je le voel bien conparer.
Folie me fist demorer, si m'an rant corpable et forfet.
Et molt grant hardemant ai fet qant devant vos osai venir; mes s'or me volez retenir,

\footnotetext{
${ }^{347}$ For a further discussion of the bipartite structure of the Yvain-story that allows for a double adventure cycle see the synopsis in the appendix to this study.
} 
jamés ne vos forferai rien'. (6786-95)

['Milady, one should have mercy on a sinner.

I have paid dearly for my foolishness, and I am glad to have paid.

Folly caused me to stay away, and I acknowledge my guilt and wrong. And I realize that I am very bold to dare to come before you now; but if you would care to keep me, I'll never do you wrong again.']

Whereas the oath pledged by Laudine may serve as an insurance that the reconciliation of the couple will come about, it is Yvain's submissiveness in this scene — signified through body and voice - that truly restores their love in the private sphere. By completely abasing himself in service of his lady, he becomes worthy again of her love. Rikhardsdottir has noted that ' $[t]$ he reconciliation and the successful resolution of the dilemma of Love are in fact contingent upon Yvain's penitence and promise to not violate the tenets of Love again. ${ }^{348}$ This image of the guilt-ridden knight asking for the pardon of his exalted lady reflects the ideology of courtly love. The submissive movement of the knee-fall and the emphasis on the fact that he performs it 'in full armour' (trestoz armez, 6737) — a description that brings to mind feudal connotations - are in support of this interpretation. After all, courtly love, in particular with regard to the lady's elevated position, is modelled on the hierarchical

\footnotetext{
${ }^{348}$ Rikhardsdottir, Medieval Translations and Cultural Discourse, 105.
} 
relationship of feudalism. ${ }^{349}$ Like the armed knight who swears fealty to his liege lord, the courtly lover serves his lady with unwavering loyalty and obedience.

\section{Mutual Responsibility}

Hartmann's Îwein also takes on the argument with Lûnet for 'most piteous' but is quick to admit defeat. When he is told that Lûnet's life is in danger, he concedes: 'Sô laze ich iu den strît,/ daz ir angesthafter sît/ danne ich.' ('In that case, I concede to you,/ that you are in a more perilous position/ than I.' $)^{350}$ Since the argument is not taken as far as in Chrétien, Hartmann's protagonist does not profess his guilt towards Lûnet. On the contrary, a few lines earlier, Îwein has been absolved from any blame by the maiden, who, as the couple's matchmaker, blames herself for her lady's failed marriage: 'Ouch ist ez nicht von den schulden sîn/ ez ist von den unsælden mîn' (4059-60) (“And yet it is not his fault -/ it is because of my own ill fortune'). Deviating on this point from Yvain, the blame for their separation falls on Lûnet multiple times in Hartmann's story. According to Joseph Sullivan, who studied the character in both source and translation, it is therefore 'not Iwein's action that has proved most instrumental in the failure of the marriage,' but, rather 'the fact that Lunet was "alze gâch" (418) (premature) in finding Îwein acceptable for her lady.,351

\footnotetext{
${ }^{349}$ See for instance Jane E. Burns, 'The Man behind the Lady in Troubadour Lyric', Romance Notes 25.3 (1985), 254-70. For a more extensive examination of feudal imagery in Yvain see Ojar Kratins, 'Love and Marriage in Three Versions of “The Knight with the Lion”, Comparative Literature 16 (1964), 29-39, at 30-32.

${ }^{350}$ Hartmann von Aue, Iwein, German Romance, ed. and trans. Cyril Edwards, vol. 3, Arthurian Archives 16 (Cambridge: D.S. Brewer, 2007), lines 4067-69. All Middle High German quotations of Iwein and their corresponding English translations cited in this dissertation have been taken from this edition and will hereafter be quoted with page numbers following their quotations. This edition is edited from Manuscript B (Gießen, Universitätsbibliothek Codex Nr. 97), but renders the omissions and additions in relation to Manuscript A. 351 'The Lady Lunete: Literary Conventions of Counsel and the Criticism of Counsel in Chrétien's Yvain and Hartmann's Iwein,' Neophilologus 85 (2001), 335-54, at 349.
} 
Assigning blame in the separation of the couple seems to be a more delicate matter in the German rewriting. Where Chrétien's knight is depicted as a sinner in search of atonement (pecheor, 6787), Hartmann's protagonist is not as distinctly profiled. ${ }^{352}$ Îwein's fault in the matter is negated once more when Îwein defends Lûnet's innocence in judicial combat against her three accusers. Afterwards, Laudîne does not recognise Îwein, who appears before her as the Knight with the Lion. Since he is obviously grief-stricken, the lady inquires after the reason for his sadness, to which 'the nameless one spoke':

'Ichn gewinne gemach nochn wirde frô
niemer unz ûf den tac,
daz ich wider gehaben mac
mîner frouwen hulde.
Der mangel ich âne schulde'. (5466-70; my emphasis)

['I'll never win rest nor be happy

until that day,

when I may regain

my lady's favour.

I lack that without blame.']

\footnotetext{
352 Both Rudolf Voss and Burkhardt Krause reject the assumptions of studies positing an individual development on the part of Iwein, see Voss, Die Artusepik Hartmanns von Aue: Untersuchungen zum Wirklichkeitsbegriff und zur Ästhetik eines literarischen Genres im Kräftefeld von soziokulturellen Normen und christlicher Antropologie (Cologne: Böhlau, 1983); Krause, 'Zur Psychologie von Kommunikation und Interaktion: Zu Iweins "Wahnsinn", in Psychologie in der Mediävistik: Gesammelte Beidrage des Steinheimer Symposion, ed. Jürgen Kuhnel et al. (Göppingen: Kümmerle, 1985), 215-42.
} 
As suggested earlier by Lûnet, Îwein himself now literally states that he has lost his wife's favour through no fault of his own. Kratins notes how, differently from the Old French source, the Middle High German translation accomodates 'the implied feeling that Iwein's suffering is not fully justified. ${ }^{353}$ These lines suggest instead that he was deprived of her love.

Since Iwein does not contain any explicit signs of acknowledgement of error or guilt on the knight's part, there is no immediate sense of him having undergone a process of atonement and growth. ${ }^{354}$ The story thus allows for a heightened sense of suspense to build up towards the ending, as the suggestion of a negative outcome for the lovers is kept alive until the very last lines of the reconciliation scene. When Îwein is brought before Laudîne, initially, he 'viel ir ze fuozze,/ und het doch deheine bet' (8110-11; my emphasis) (fell at her feet/ and yet made no request.) The coaction of body and voice in Yvain is rescripted in Hartmann's rendition of the scene: rather than functioning as an amplification of the knight's performative gesture, as has been shown for Yvain, Îwein's speech (or better said non-speech) is deployed to negate his bodily action. Although Îwein submits himself to Laudîne by kneeling at her feet, it is explicitly stated that he does not yet vocalise his penitance. His passive demeanour towards Laudîne stands in the way of the couple's reunion. What is holding him back?

Edwards rightly points out that Îwein's silence in this scene 'echoes that of his first face-to-face encounter with Laudine. ${ }^{355}$ This encounter occurs after Îwein has fought and killed Laudîne's husband, King Ascalon (Appendix, Synopsis, episode II). In an attempt to receive the lady's forgiveness for the injury he has done her by killing her husband, Îwein falls at her feet. This somewhat overlooked knee-fall may well help to put Îwein's silence into

\footnotetext{
${ }^{353}$ Kratins, The Dream of Chivalry, 202.

${ }^{354}$ Although this maturation process is still implied by the nature of the adventures Îwein undertakes in the second adventure cycle, which is, unlike the first cycle, reflective of societal profit instead of personal gain. See also Voß, who argues that Íwein's guilt and maturation cannot be sought in the inner make-up of the hero, but should be found in the collective value of his adventures (Die artusepik Hartmanns von Aue, 1).

${ }^{355}$ Iwein, ed. and trans. Edwards, 413, see note 140.
} 
context, as the passage essentially mirrors the demonstrative behaviour of the lovers in the Bending. Having fallen madly in love at the sight of his enemy's widow-a description that similar to Yvain involves Ovidian tropes like the arrow and wound of Love- - Iwein requests an audience with her. ${ }^{356}$ However, when he finally receives it, he meets with a rather cold reception:

Dô er chom gegangen, weder sî ne sprach nochn neic.

Dô sî also stille sweic, daz begunde im starche swâren und enweste wie gebâren. (2244-48)

[When he came walking up she neither spoke nor bowed. When she was thus silent, that started to trouble him greatly and he did not know how to act.]

As the passage above states, Laudîne's silence makes the knight uncomfortable as he becomes painfully aware of the fact that he is to perform some kind of act towards gaining her favour. After they sit in silence for a while, it is up to Lûnet - whose guidance in her role as mediator between the lovers is also paralleled in this scene-to explain to the inexperienced knight the stipulations regarding their exchange. She points out that it is his turn to act, seeing that he is the one that gave injury. After all, he has killed Laudîne's husband in single battle and needs

\footnotetext{
${ }^{356}$ For a discussion of these tropes see chapter one of this study, pp. 104-7, 111-13.
} 
to be granted forgiveness. Lûnet's speech propels Îwein into action:

Dô ne wart niht mê gesezzen.

Er bôt sich drâte ûf ir fuoz,

und suochte ir hulde und ir gruoz

als ein schuldiger man. (2278-81, my emphasis)

[Then he remained seated no longer.

He knelt quickly at her feet,

and besought her favour and her greeting

as a guilty man.]

Both this scene and the reconciliation scene in the B-ending unfold along the same lines: as the lovers come face-to-face, an act of silence on the one's part prompts a move towards reconciliation on the part of the other. According to Patrick McConeghy, Hartmann 'understood the dramatic value of speech' and invested deeply in giving voice and non-voice to his characters. ${ }^{357}$ Like the knee-fall, the act of silence functions as a narrative sign in both scenes. Both acts thus become performative, as they signify the power relations between the lovers at that moment in the narrative and help interpret the scene. ${ }^{358}$

Notably, the roles of Schuld and Unschuld, of asking and granting forgiveness, are mirrored in both scenes. Whereas Laudîne is the granting party in the scene above, she

\footnotetext{
357 'Women's Speech and Silence in Hartmann von Aue's Erec,' Publications of the Modern Language Association of America 102. 5 (1987), 772-83, at 773.

358 'Performative' is here understood as a textual gesture, see John L. Austin, How to do Things with Words (Cambridge, Mass: Harvard University Press, 1962). Austin presents speech as forms of action. His concept of a speech-act is particularly helpful in envisioning speech — or in this case non-speech — as a performative (in the form of staging), although Austin himself excluded fictional speech.
} 
becomes the asking party in the B-ending. After she has bidden the prostated knight to rise, it is, Laudîne who brings about their unity in the private sphere:

'Her Îwein, lieber herre mîn, tuot gnædeclîche an mir.

Grôzzen chumber habt ir

von mînen schulden erliten.

Des wil ich iuch durch got biten,

daz ir ruochet mir vergebn,

wander mich, unz ich hân daz lebn,

von herzen iemer riuwen muoz.'

Dâ mit viel sî an sînen vuoz

und bat in harte verre. (8190-99)

['Sir Iwein, my dear lord,

act graciously by me.

You have suffered great troubles,

for which I was responsible.

Therefore I will request you by God

to deign to forgive me,

for those troubles, as long as I live,

must ever grieve me to the heart.'

Thereupon she fell at his feet

imploring him most vehemently for forgiveness.] 
Not just Laudîne's knee-fall, but also Îwein's act of silence that seems to trigger it, have no source in Yvain. Chrétien presents the couple's separation as an individual offence instead. The injury against Love is assigned to Yvain and as such there are no expectations on the part of Laudine apart from the oath that was sworn. Kratins points out that the lady pardons Yvain only under the pretext of necessity that the oath brings and that the reconciliation is not necessarily of her own volition. This image of a knight who places himself in power and service of an unapproachable lady fully agrees with the conventions of courtly love. ${ }^{359}$

The German rendition of the story, however, reflects a shared contrition as well as mutual affection, as the love dilemma seems to be redirected towards a test of partnership. McConeghy notes that 'Hartmann attempts to balance the positions of the lovers in the reconciliation scene, where both partners come to share equal blame'. ${ }^{360}$ Minimising Îwein's blame in the separation in the build-up to the reconciliation scene, the reversed power relations in the lovers' first meeting, Îwein's silence and Laudîne's subsequent prostration in the final passage indeed all seem to build towards a dénouement in which the responsibility for the separation of the couple and their suffering is shared. The lady's knee-fall at Îwein's feet suggests that she is no longer the haute dame portrayed in Yvain, but the Ehefrau Laudîne, who, quite literally, climbs down from the pedestal in order to symbolize a more equal image of love. Yvain's gendered notion of courtly love, in which the knight unconditionally acts in service of his revered lady, is reformulated in Iwein into a more consensual image of love, in which the responsibilities of marriage are shared, as expressed in Ehe-Minne.

\footnotetext{
${ }^{359}$ Kratins, 'Love and Marriage in Three Versions of "The Knight with the Lion", 34.

${ }^{360}$ Hartmann von Aue: Iwein, ed. and trans. McConeghy, xxiv.
} 


\section{Enite's Knee-Fall}

Unlike French courtly love or German Hohe Minne (high love), distinctive for its feudal and at times erotic nature, Ehe-Minne in Middle High German literature is conventionally associated with mutual devotion and marriage. The term itself loosely translates into 'love within the institute of marriage. ${ }^{361}$ Alexandra Sterling-Hellenbrand portrays this literary love ideal to promote 'an equal partnership, a relationship which would incorporate the passion of minne and in which each partner fulfilled her or his role appropriately'. ${ }^{362}$ 'Equality' must here be understood as relative and must be placed within the context of twelfth-century medieval society in which, according to Dennis H. Green, a shift took place towards concensual marriage that also involved a reciprocal marital duty for both partners (debitum) ${ }^{363}$ Sterling-Hellenbrand notes that particularly the German romances seem to reflect these shifting views as they uphold 'the ideal of woman and man as partners in their marriage'. 364

Of particular importance to this conjugal partnership was triuwe (loyalty), as it controlled the moral actions of characters and stipulated rules of social conduct. ${ }^{365}$ Unlike

\footnotetext{
${ }^{361}$ There is no standard work on Ehe-Minne and its definition has not yet been normalised. As a term it does occur in a number of individual studies: Thomas Grenzler, Erotisierte Politik—Politisierte Erotik?: Die politisch-ständische Begründung der Ehe-Minne in Wolframs Willehalm, im Nibelungenlied und in der Kudrun, Göppinger Arbeiten zur Germanistik 552 (Göppingen: Kümmerle Verlag, 1992); Kathryn Smits, 'Enite als christliche Ehefrau,' in Interpretation und Edition deutscher Texte des Mittelalters: Festschrift für John Asher, ed. Kathryn Smits, Werner Besch and Victor Lange (Berlin: Erich Schmidt Verlag, 1981), 13-25; and in the same volume Siegfried Grosse, 'Die Variationen der Minne in den Dichtungen Hartmanns von Aue,' 26-38. ${ }^{362}$ The Topographies of Gender in Middle High German Arthurian Romance (New York/London: Routledge, 2001), 52 .

${ }^{363}$ Women and Marriage in German Medieval Romance (Cambridge: Cambridge University Press, 2009$), 21$.

${ }^{364}$ Sterling-Hellenbrand, The Topographies of Gender, 89.

${ }^{365}$ For a discussion of triuwe in relation to Ehe-Minne see named works and in particular Bumke, Höfische Kultur: Literatur und Gesellschaft im hohen Mittelalter (München: Deutscher Taschenbuch Verlag, 1986), 52729. On the semantics of triuwe in its different contexts, see Simone Schultz-Balluff, Wissenswelt 'Triuwe': Kollakationen - Semantisierung - Konzeptualisierung (Heidelberg: Universitätsverlag Winter, 2018). Triuwe
} 
courtly love, which chiefly comes about in the private sphere, Ehe-Minne also demonstrates a public and therefore social importance. Thomas Grenzler has shown it to have a political function, as it joined together royal families and it guaranteed peace and power within the state. ${ }^{366}$ Indeed, social responsibility seems to be an important motivational force behind Laudîne's knee-fall in Iwein. ${ }^{367}$ No matter what Laudîne's private feelings on the matter might be, her public role requires her to reconcile with Îwein. As the lady of the land of the Fountain, she is obliged to actively bring about unity and peace for her people by reestablishing the male ruler of the land. The redirection of the image of courtly love into EheMinne by presenting a couple that is connected through marriage and rulership, connects Iwein to Hartmann's Erec, which is reflective of corresponding marital practice when it comes to reconciling lovers.

Close in plot to Iwein, Hartmann's Erec revolves around harmonising knighthood and love. Like Îwein, Erec, once he is caught up in marital bliss, is guilty of verligen (languishing in bed) ${ }^{368}$ Being completely in the thralls of love, rumours start to spread that Erec has come

has a wide semantic range as the term occurs in multiple literary contexts. In its broadest definition signifies 'a most enduring and noble quality', whether it is applied in an earthly, spiritual or legal domain or concerns Minne. In its latter function in Middle High German romance the term is often used in reference to female characters (Schultz-Balluff, Wissenswelt, 345-47).

${ }^{366}$ Grenzler, Erotisierte Politik-Politisierte Erotik.

${ }^{367}$ See for instance Volker Mertens, Laudine: Soziale Problematik im Iwein Hartmanns von Aue, Beihefte zur Zeitschrift für deutsche Philologie 3 (Berlin: Schmidt, 1978).

${ }^{368}$ Note that this is much more the case for Îwein than it is for Yvain. Whereas in Yvain the main focus is on the mistake of verrittern, the danger of verligen is just as much at issue in Iwein. What in Chrétien is about a fiftyline piece of advice by Gauvain to guard his reputation as a knight (Yvain, 2542-89) has been expanded into a one-hundred-and-forty-five-line reproach by Gâwein (Iwein, 2761-906), in which Hartmann not only literally compares Îwein's situation to that of 'herren Êreke' (2786-88), but also deploys the same vocabulary in describing the offence (verligen, 2784-88; gemach (ease), 2785). 'Certainly', Frank Tobin notes with regard to this specific reference to the fate of Erec, 'Hartmann cannot be accused of overestimating the interpretative abilities of his audience!' ('Hartmann's Erec: The Perils of Young Love', Seminar 14 (1978), 1-14, at 1). Verligen as a literary motif refers to spending the days languishing in bed. It literally translates into 'lying too 
to neglect his knightly duties. Where Erec is found guilty of verligen, his bride Enite makes the mistake of verswigen (keeping silent). Although she has become aware of the gossip concerning Erec's reputation, she decides to hold this information back from him. One night, Erec overhears Enite voicing her concerns over her husband's negligence, when she believes him to be asleep. The next morning Erec takes her on a journey on which she is not to speak a single word.

In Erec, silence is again ascribed an important role by Hartmann when it comes to the maturation and eventual reconciliation of the couple. Similarly to Iwein, silence seems to demand action in Erec. Not only does the Schweigegebot (command for silence) leave room for chivalric action on Erec's part, providing him with the opportunity to restore his honour, but it also, ironically, demands performance on Enite part: by speaking up, she saves her husband's life each time she acts. This irony is also addressed by McConeghy, who argues that the command of silence does not serve as a way to 'repress Enite's voice in the romance', but instead serves to test her, making her realize that she 'ought to have spoken all along'. 369

long'. Verritern can be posed as its antonym and refers to a protagonist who neglects his marital duties in order to pursue chivalric aspirations. For a more elaborate discussion of verligen: see Julia Haase, Das 'verligen' und das daraus resultierende Schweigegebot im Erec Hartmanns von Aue (München: GRIN Verlag, 2010). ${ }^{369}$ McConeghy, 'Women’s Speech and Silence,' 772. See also Wendy Sterba, 'The Question of Enite's Transgression: Female Voice and Male Gaze as Determining Factors in Hartmann's Erec', in Women as Protagonists and Poets in the German Middle Ages, ed. Albrecht Classen, Göppinger Arbeiten zur Germanistik 528 (Göppingen: Kümmerle, 1991), 57-68. McConeghy is here arguing against those interpretations that maintain that the issue of guilt should solely be sought with Erec. Enîte's role in Hartmann has elicited many different interpretations. While some studies maintain that both Erec and Enîte are accountable for Erec's negligence of his duties, others ascribe guilt solely to Erec. Silvia Ranawake, for instance, relieves Enide of any responsibility in the matter ('Erecs verligen and the Sin of Sloth', in Hartmann von Aue: Changing Perspectives, ed. Timothy McFarland and Silvia Ranawake, Göppingen: Kümmerle, 1985, 93-116, at 115). Rodney Fisher believes Erec's guilt to ultimately stem from, not his verligen, but from projecting his own sin unto Enîte ('Erecs Schuld und Enites Unschuld bei Hartmann', Euphorion 69 (1975), 160-174). This subordinate role of Enite is also addressed by Karen Pratt, who maintains that Hartmann's Erec offers a passive representation of women as the romance focus solely goes out to Erec's adventures and growth ('Adapting Enide: Chrétien, Hartmann and 
Likewise, Kathryn Smits suggests approaching Hartmann's rendition as a test of partnership and rejects the issue of Schuld and Unschuld for either Enite or Erec. ${ }^{370}$ Other than Chrétien's story, she notes, 'die Frage nach der Schuld der Individuen Erec und Enite nimmt keine zentrale Stellung ein' (the question of individual guilt of either Erec or Enite does not take a central position) in Hartmann's rendition. Instead, she argues ‘da $\beta$ es ihre Ehegemeinschaft ist, ihre Partnerschaft als Mann und Frau, welche auf die Probe gestellt wird' (it is their marital union, their partnership as man and wife, which is put to the test.), ${ }^{371}$

Indeed, like in the French text, Enite is forced to break her silence several times in order to warn her husband against danger. By the time they arrive at Count Galoein's to take lodging for the night, Enite has already broken her vow of silence twice. When Enite is coveted by the Count, who intends to kill Erec as soon as the day breaks, she feels that again she is left no choice but to warn her husband a third time. Although Chrétien's Enide likewise speaks up, Hartmann's Enite is, unlike Chrétien's female protagonist, much more aware of her earlier wrongdoing and experiences clear distress when trespassing against her promise. In her wish to be a good wife to Erec, she is afraid of going against her husband's wishes yet again, since she is sure to lose his favour should she do so. This internal struggle comes to expression in Hartmann's story in the following soliloquy, as we find Enite mulling over her thoughts at night:

Nû gedâhte diu guote

alsô mit muote:

'Ez ist mir ûf daz zil gekomen, daz mir benamen wirt benomen

the Female Reader', in Chrétien de Troyes and the German Middle Ages, ed. Martin H. Jones and Roy E. Wisbey, Arthurian Studies 26, Cambridge: D.S. Brewer, 1993, 67-85, at 69).

${ }^{370}$ Smits, 'Enite als christliche Ehefrau', 13-25.

${ }^{371}$ Ibid. 13, my translation. 
der allerliebiste man,

den ie wîp mêr gewan,

ez ensî daz ich in warne.

Ouch weiz ich, daz ich ez erarne,

zebriche ich aber sîn gebôt.

Nû rât mir, herre, rîcher Got!

Des enwart mir nie sô nôt.

Ich weiz wol, ez ist mîn tôt,

wan er hât mirz nû zwir vertragen. ${ }^{372}$

[Now the good lady thought

to herself:

'It has reached the point

that the dearest husband

that ever $a$ wife won

will be taken from me, for sure,

unless I warn him.

Yet, I also know that I will pay for it

if I break his command again.

Now counsel me, Lord, mighty God!

I was never so much in need of it.

I know full well that it will mean my death,

\footnotetext{
${ }^{372}$ Hartmann von Aue, Erec, German Romance, ed. and trans. Cyril Edwards, vol. 5, Arthurian Archives 19 (Cambridge, UK: D.S. Brewer, 2014), lines 3972-84, my emphasis. All Middle High German quotations of Erec and their corresponding English translations cited in this dissertation have been taken from this edition and will hereafter be quoted with line numbers following their quotations.
} 
for he has now tolerated it from me twice.']

In her contemplation, Enîte carefully weighs her responsibilities as a wife against those as a lover. She is torn between fulfilling her marital duties, which demand unquestioning obedience, and meeting her personal wishes by saving the man she loves. This internal struggle is not addressed at this point in Erec et Enide, nor does the corresponding French text passage resonate the womanly obedience inspired by Enîte's wish to amend her past mistake. ${ }^{373}$ Where Hartmann depicts Enîte, first and foremost, as a wife (wîpe, 3977) who fears disobedience, Chrétien presents his Enide in line with courtly convention, as a lady (dame, 3459, corresponding text passage follows below), who, despite being 'kind of heart and solicitous' (3458-59, idem), acts in a far less subservient way.

Antonín Hrubý notes that the German passage reveals a consistent, and ostensibly deliberate, suppression of courtly love terminology:

Weder hier noch in der ganzen Versöhnungsszene, die bei Hartmann dreiundvierzig Verze umfaßt, werden die Ausdrücke minne oder vrouwe nur ein einziges Mal gebraucht. Enite wird dagegen mehrmals als wîp bezeichnet, womit in diesem Zusammenhang natürlich Gattin oder Gemahlin, also geradezu das Gegenteil von vrouwe gemeinst ist. ${ }^{374}$

\footnotetext{
${ }^{373}$ Although her struggle with keeping silent is vocalised and/or described at other points in the narrative (Fritz, 2829-39; 2962-78; and especially, 3735-37), this struggle is motivated by love as well as a sense of selfpreservation. It arises from a sense of fear of losing Erec, that 'he may be killed or taken prisoner' (Kibler, 72), and, more specifically, out of fear what would happen to her without him 'but if my lord would be killed here, nothing could comfort me, I would be dead and destroyed' (73); 'I am certainly sure that my bereavement will be too great if I lose my lord here' (83) rather than out of fear of going against her marital duties.

374 'Die Problemstellung in Chrétiens und Hartmanns Erec', in Hartmann von Aue, ed. Hugo Kuhn and Christoph Cormeau (Darmstadt: Wisschenschaftliche Buchgesellschaft, 1973), 342-72, at 342.
} 
[Neither here, nor in the entire reconciliation scene- that takes up forty-three verses in Hartmann — are the terms minne (love) or vrouwe (equivalent of dame, i.e. lady) used even once. Enite, on the other hand, is referred to as wip multiple times, which in this context of course means wife or consort, that is, denoting downright the opposite of vrouwe.]

Hartmann's reformulation of courtly love terminolgy and the reframing of Erec's meaning to test Enite, not as a lover, but predominantly as a spouse, leads Hrubý to conclude that it is 'ohne weiteres klar daß der Dichter keineswegs Troubadourminne, sondern ein reales Eheverhältnis im Sinne hatte ${ }^{375}$ [immediately clear that the poet by no means had a courtly love relationship in mind, but a true marital relationship instead.]

Indeed, the discomfort expressed by the German Enite over going against her husband's wishes seems to have a different source in the French passage. The audience does not know Enide's thoughts directly by means of interior monologue, but her state of mind is described by the narrator instead. Whereas Enîte's distress stems from going against marital stipulations, Chrétien's Enide fears for her lover's life as she worries about whether he will believe her:

De li ne set nul reconfort; toute la nuit veillier l'estuet, mais ainz le jor, se ele puet et ses sires la vuille croire,

\footnotetext{
${ }^{375}$ Hrubý, 'Die Problemstellung in Chrétiens und Hartmanns Erec', 347. Smits likewise makes this connection, but places Erec and Enite's partnership in the context of the popular theological teachings of the late twelth century by presenting it as an ideal Christian marriage ('Enite als christliche Ehefrau', 13-25).
} 
avront aparoillié si lor oirre.

vers son seignor ot le cuer tendre,

come bone dame et lëax:

ses cuers ne fu dobles ne faux. (3446-60, my emphasis)

[Enide could not be comforted;

throughout the night she stayed awake,

but if she could, before daybreak,

if her lord took her word as fact,

they would be set to leave and packed.

Toward her lord she was kind of heart,

a lady true, solicitous:

her heart was not duplicitous.] $]^{376}$

Although her wish to be a good wife makes the German Enîte hesitant to break her promise, ironically it is her loyalty to her husband that compels her to speak. 'Triuwe' (3993) (loyalty) commands her to look after her husband, which she offers him, unlike her French namesake, on her knees:

Ir triuwe ir daz gebôt,

daz si zuo sînem bette gie

${ }^{376}$ Chrétien de Troyes, Erec and Enide, trans. Ruth Harwood Cline (Athens, GA/London: University of Georgia Press, 2000), p. 101, my emphasis. The translated passages will hereafter be quoted with page numbers following the translation. 
und bôt sich vür in an ir knie,

und saget im die rede gar. (3993-96, my emphasis)

[Her loyalty commanded her

to go to his bed

and get down on her knees before him,

and tell him all about the business.]

The necessity behind Enîte's warning is inspired by their bond in marriage, as triuwe 'commands' her (gebôt, 3980; 3993) to break her silence. ${ }^{377}$ This bond is symbolised by Enîte's knee-fall. Let it be noted here that Enîte is not simply kneeling by Erec's bedside, as the English translation above would indicate. The Middle High German specifies the implications of the lady's gesture: she 'bôt sich vür in an ir knie,' or, in other words, she offers herself and her services up to him on her knees. ${ }^{378}$ By speaking up, albeit in a humble

\footnotetext{
${ }^{377}$ For the semantic occurrence of (un)triuwe in Hartmann's Erec see Schultz-Balluff, Wissenswelt, 356. Peter Wapnewski underlines the Treuproben (test of loyality) that constitutes the image of love in Hartmann's Erec. Wapnewski sees this test of loyalty within marriage as a redirection of the traditional 'Treuprobenmotive'. Instead of a test of faithfulness, Treuproben becomes a test of partnership in Hartmann, with triuwe as its highest value, as 'Ereks und Enites Liebe war nicht "wirklich", nicht errungen, sondern rasch erworben, nicht verdient, sondern schell gewährt', (Erec's and Enite's love was not "real", not achieved, but acquired quickly, not earned, but granted) (Hartmann von Aue, Sammlung Metzler Realien zur Literatur 17, Stuttgart: J.B. Metzler, 1979, 51, my translation). H.B. Willson shows Erec and Enite to have different views of triuwe-where Erec believes Enîte to be untriuwe because she breaks his command for silence, Enîte believes her triuwe lies in speaking upthat need to be reconciled before the couple can be truly united ("Triuwe and Untriuwe" in Hartmann's Erec', German Quarterly 43 (1970), 5-23). Bruno Quast likewise argues that what is essential to Erec and Enites love a union based on mutual triuwe ("Getriuwiu wandelunge": "Ehe" und "Minne" in Hartmanns Erec', Zeitschrift für deutsches Altertum und deutsche Literatur 122 (1993), 162-80).

${ }^{378}$ The servitude ('Unterwerfung') implied by Enîte's knee-fall is also addressed by Peil in Die Gebärde bei Chrétien, Hartmann und Wolfram at 202.
} 
manner through her lowered position, Enîte shows her husband that she has learned from her earlier mistake of verswigen and is willing to assist him in restoring his honour.

This submissive gesture on the lady's part is not referred to in the French source, which continues:

Ele se lieve et apareille,

a son seignor vint, si l'esveille:

'Ha! sire, fait ele, merci!

Levez isnelemant d'ici,

que trahiz estes antresait

sanz achoison et sanz mesfait. (3461-67)

[She made her preparations, dressed,

came to her lord, and broke his rest.

'Ah, sir' she cried, 'oh, mercy me!

You must arise immediately,

for you have fallen prey to treason,

without misconduct or good reason.'] (102)

Unlike Hartmann's female protagonist, Enide's warning does not resonate marital duty, but instead seems to be inspired by a genuine concern for her lover's life, as well as perhaps for her own. Her exclamation ('oh mercy me!') resonates a sense of self-preservation concerning what would befall her should she fall into the hands of the dishonorable count. 


\section{Conclusion}

This chapter has demonstrated that gestures, such as kneeling, fulfil an important function when it comes to the staging of emotion. Where the modern reader has often described Chrétien's ending and the resolution to the love dilemma as 'emotionally contrived', 'unconvincing' and 'patched together', this chapter shows that there is affective meaning to be found in Yvain's knee-fall. ${ }^{379}$ It may be conceived of as a narrative sign that communicates information of an emotional nature to the reader/listener. The fact that the German rendition adopts the kneeling gesture and restages its context in the B-variant, only confirms its weight as a narrative sign.

Examining these bodily actions through the lens of emotive performativity has revealed a difference in the love ideal portrayed in Chretien's story and both its German variants. In Iwein's B-ending, the German adaptor has been shown to renegotiate the codes of courtly love in Yvain's emotive script by incorporating female action and speech. Further investigation into the narrative's motivation behind Laudîne's contrition has revealed other emotive redrawings of the story in Iwein - where both the A- and the B-redaction run parallel — that likewise attest to a resignification of the image of love exemplified in Yvain. When viewed in light of Laudîne's knee-fall, these reformulations may be perceived as an indication that the B-ending is perhaps more 'original' than is often believed. The recurrent negation of Îwein's fault in the separation, the reversed prostration scene upon the lover's first encounter, and more importantly, Îwein's act of silence leading up to Laudîne's knee-fall all seem to prefigure the lady's contrition expressed by her kneeling gesture at the end of the story. Like Laudîne's genuflection, these emotive redirections turn individual offence as well

\footnotetext{
${ }^{379}$ See for example Leslie Topsfield, Chrétien de Troyes: A Study of the Arthurian Romances (Cambridge: Cambridge University Press, 1981), at 204; Joseph Duggan, The Romances of Chrétien de Troyes (New Haven: Yale University Press, 2001), at 118-19.
} 
as one-sided affection into mutual responsibility and an image of reciprocal love, thereby reformulating courtly love into Ehe-Minne.

The additional focus on the lady Laudîne's contrition and the thus transformed love ideal may be indicative of a divergence in the tastes and expectations of the targeted German audience from the French. Whether 'original' to the German story or not, the extra verses in the B-ending possibly mark a shift in this horizon of feeling that may indeed, as suggested by Edwards, have been brought on by the popularity of Hartmann's Erec. The same redirected love ideal has been assigned to the Middle High German adaptation of Chrétien's Erec et Enide. As in Iwein, courtly love is resignified into Ehe-Minne in Hartmann's Erec. Enîte's bodily actions and speech have likewise been altered in order to convey an image of love dependant upon partnership and reciprocal marital responsibilities.

Although in both the emotive scripts of Yvain and Erec et Enide, the codes of courtly love are grafted onto the institution of marriage - a representation of courtly love that is very different, for example, from the relationship of Guinevere and Lancelot in Chrétien's Le chevalier de la charrette - these principles are profoundly different from the marital virtues foregrounded in the German renditions of Chrétien's narratives that are based on the central ideal of triuwe (loyalty). Equally different is the image of the German heroines. Laudine and Enîte are loyal and compliant wipes (wives), not the hautes dames (revered ladies) of courtly love, to whom the knight submits without question. In both Iwein and Erec, the heroine's kneeling gesture removes the hierarchical relationship and emotional distance that exist in Chrétien's romances, not only between the superior lady and her attentive knight, but also, as Kratins has pointed out, between the lady and the audience, as 'Hartmann places her on the same level with Iwein [/Erec], that is on a level with which the audience can identify' and 
feels therefore - in complete disagreement with the literary conventions of courtly love- free to criticise. $^{380}$

\footnotetext{
${ }^{380}$ Kratins, 'Love and Marriage in Three Versions of "The knight with the Lion”, 37.
} 


\section{CHAPTER THREE: MEDIATING IMAGES OF COLLECTIVE EMOTION}

The Construction of the Communal Feeling in Yvain, Ívens saga and Ywain and Gawain

The previous chapters have focused on individual emotion. Chapter one explicates the interior processes involved in a character when experiencing emotion, while chapter two foregrounds the external expression of emotion by a character. This is how emotions have traditionally been understood: as experienced and expressed by an individual. However, this interpretation has begun to be challenged. Scholars are increasingly examining emotion as a collective phenomenon, that is, as the experience and expression of one and the same emotion by a group of people. ${ }^{381}$

\footnotetext{
${ }^{381}$ The recent decade(s) have seen an increase in studies on collective emotions, whether conceptual (e.g. Christian von Scheve and Mikko Salmela, eds, Collective Emotions: Perspectives from Psychology, Philosophy, and Sociology, Oxford: Oxford University Press, 2014; Bryce Huebner, 'Genuinely Collective Emotions', European Journal for the Philosophy of Science 1 (2011), 89-118; Miko Salmela, 'Shared Emotions', Philosophical Explorations: An International Journal for the Philosophy of Mind and Action 15.2 (2012), 3346; Anita Konzelmann Ziv, 'The Semantics of Shared Emotion', Universitas Philosophica 26.52 (2009), 81106; Janusz A. Holyst, ed., Cyberemotions: Collective Emotions in Cyberspace, Berlin: Springer, 2017); or case studies of basic group-emotion and related feelings, such as anger and grief (e.g. Emma Hutchison, Affective
} Communities in World Politics: Collective Emotions after Trauma, Cambridge: Cambridge University Press, 2016; Thomas J. Scheff and Suzanne Retzinger, Emotions and Violence: Shame and Rage in Destructive Conflicts, Lexington, MA: Lexington Books, 1991), shame and guilt (e.g. Nyla R. Branscombe and Bertjan Doosje, eds, Collective Guilt: International Perspectives (Studies in Emotion and Social Interaction), New York: Cambridge University Press, 2004; Glenn Pettigrove and Nigel Parson, 'Shame: A case Study of Collective Emotion', Social Theory and Practice 38 (2012), 1-27), and joy and pride (e.g. Edith Turner, Communitas: The Anthropology of Collective Joy, Basingstoke: Palgrave, 2012; Andy Clark, 'Spreading the Joy?' Mind 118 (2009), 963-93). The groundwork for these studies was laid before the affective turn by a series of pioneering publications from the late nineteenth- and early twentieth century that focused on collective consciousness and crowd behaviour, see Gustave Le Bon, Psychologie des foules, ed. Félix Alcan (Paris: 1895), published in English as The Crowd: A Study of the Popular Mind (New York: Cosimo Classics, 2006, first published in 1896); William McDougall, The Group Mind (New York: Putnam, 1920); Gabriel Tarde, Les lois de l'imitation: Étude sociologique (Paris: Félix Alcan, 1890), translated in English as The Laws of Imitation, trans. Elsie Clews 
Whether positive or negative, collective emotions are contingent upon an in-group identity, i.e. a sense of 'us', a feeling of belonging to that group that is shared by all its members. ${ }^{382}$ We may, for instance, witness such shared emotion at sport games as fans collectively cheer for their team and express joy over its victory. Similar in-group sentiments underlie the collective emotions that arise from political preference (during demonstrations or at a campaign rally) or from cultural or religious practices (during feasts, rituals, prayer or other types of veneration). While the ability to assign emotion to a collective is still debated by researchers for real social life due to a so-called individualism about consciousness, ${ }^{383}$ images of collective emotion are beginning to be examined for fictional life, in which the

Parsons (New York: Henry Holt and Company, 1903); Émile Durkheim, Les formes élémentaires de la vie religieuse (Paris: Félix Alcan, 1912), translated as The Elementary Forms of the Religious Life, trans. Joseph Ward Swain (London: Allen \& Unwin, 1912).

${ }^{382}$ See for instance Agneta Fischer, Over de zin en onzin van emoties (Amsterdam: Bert Bakker, 2010), 175. For a useful overview of in-group and out-group identities see Dominic Abrams and Michael Hogg, Social Identifications: A Social Psychology of Intergroup Relations and Group Processes (London: Routledge, 2006), See chapter 5 for affective reactions and chapter 7 for emotions. In-group and out-group identitities have developed out of social identity theory. Social identity theory poses that a person's behaviour and sense of who he or she is is based on their group membership(s). It was formulated by social psychologists Henri Tajfel and his colleagues at the University of Bristol in the 1970s and 1980s to explain inter-and intra-group behaviour (Henri Tajfel, 'Social categorisation'/'La catégorisation sociale', in Introduction à la psychologic sociale, vol. 1, ed. S. Moscovici, Paris: Larousse, 1972). Taking part in the shared goals, beliefs, standards and norms to inspire joint commitment is what makes someone an in-group member, failing to satisfy the obligation criterion is what excludes said members from the in-group.

${ }^{383}$ Drawing on Émile Durkheim's observations on 'collective consciousness', sociologist Margaret Gilbert for instance argues for the existence of a homogenous emotional state, posing that 'for the group to have an emotion would be for there to be an associated state of consciousness of its own' ('How We Feel: Understanding Everyday Collective Emotion Ascription', in Collective Emotions: Perspectives from Psychology, Philosophy, and Sociology, 17-31, at 19). In philosophy such theories tend to be greeted with scepticism. Christopher Kutz, for example, dismisses the possibility of collective emotions, arguing that a group's affective state is still dependant upon the personal affective states of its individual members (Complicity: Ethics and Law for a Collective Age, Cambridge: Cambridge University Press, 2001, 196). This thesis is referred to as individualism about consciousness. Supporters of this thesis argue that only individual human beings can have emotions. 
nature, function and expression of such shared feeling can be inferred from the text and the consciousness of characters does not go beyond its construction in the text.

This chapter presents such an examination of group emotion for Yvain. The communal feeling is a set-piece narrative element in Chrétien's romances. ${ }^{384}$ Groups of characters like 'all the men and women', 'everyone at court', 'all the maidens', who act like one emotional organism in expressing joy, anger, sadness or fear, feature throughout Yvain. Given that these characters are but minor actants in the plot, their repeated display of emotion in a scene is noteworthy. Much attention goes out to the somatic and vocal reactions of these communities, typically foregrounded in narrative spaces that allow for the witnessing- and evaluation of the knight-protagonist, such as the jousting terrain or the court. Arrival scenes in particular invite the community's appraisal and are critical for the construction of the knight's reputation and identity. ${ }^{385}$ This chapter examines how and why the communal feeling is foregrounded in arrival scenes in Yvain. It explores the representation and function of those images of collective emotion within Yvain's emotive script in comparison to their rendition in Ívens saga and Ywain and Gawain, translations that have been ascribed a similar resumptive style when it comes to abridging or omitting repetitious and superfluous elements in the story that impede the narrative action.

\footnotetext{
${ }^{384}$ See for instance Brandsma, who argues that the communal feeling is explored by Chrétien in order 'to play on the expectations and feelings of his audience' (Brandsma, 'The Court's Emotions', in Cultures courtoises en mouvement, ed. Isabelle Arseneau and Francis Gingras, Montréal: Presses de 1'Université de Montréal, 2010, $74-82$, at 76 .

385 As described for the Arthurian world by Larrington (“"Wy3e, welcum iwys to pis place!": Emotions in the Schemas for Arrival, Return and Welcome at the Arthurian Court', Journal of the International Arthurian Society 4.1 (2016), 92-103) and Sarah E. Gordon ('The Man with No Name: Identity in French Arthurian Verse Romance', Arthuriana 18.2 (2008), 69-81, especially at 70-71).
} 


\section{Arrival Scenes}

Andrew Lynch, Carolyne Larrington and Frank Brandsma show collective emotions to have a social function in the Arthurian world, in which the emotional life of the individual is closely bound up with that of the community. ${ }^{386}$ The community is typically invited to affirm or, conversely, call into question the in-group identity of the protagonist. As the knight embarks upon different adventures and travels through different lands he meets different communities. In such arrival scenes different welcome schemas may be at play as the in-group, that is the courtiers, the maidens, the townspeople, interpret and react to the arrival of the knight, who may represent the Other in such encounters. Drawing on Frijda's appraisal theory, ${ }^{387}$ Larrington notes: 'Cognition too comes into play as the court assesses and interprets the social meaning of the newcomer's appearance, for perception and affect are closely related in medieval models of emotion., 388

The knight's identity with regard to the community also underlies the storyline and adventure sequence of Yvain, wherein Chrétien brilliantly explores the unity or, conversely, behavioural tensions that may arise from this relationship. In-group and out-group sentiments are strongly at play when Yvain encounters the household of the Dame de Noroison, the people of Landuc and Gauvain's family. In this sequence of appraisals and re-appraisals,

\footnotetext{
${ }^{386}$ In the set up of the third case study, this chapter is inspired by the thematic session on 'Positive Arthurian Emotions' held at the XXIVth Congress of the International Arthurian society in Bucharest in 2014 that developed into a set of essays on the same topic published in Journal of the International Arthurian Society 2016. See especially, Lynch, 'Positive Emotion in Arthurian Romance', 54; Larrington, “'Wyze, welcum iwys to pis place!’’, 92-103; Brandsma, 'blide ende drove: Mixed Emotions in Middle Dutch Arthurian Romance', JIAS 4.1 (2016), 104-12.

${ }^{387}$ Frijda's discussion of appraisal theory poses that emotions are preceded by an evaluation of a situation or an event that in turn brings about a state of action readiness in a person. This is further adressed in the section 'Defining Emotion' in this study.

${ }^{388}$ Larrington, “"Wy3e, welcum iwys to pis place!"”, 93. See also Corinne Saunders, 'Mind, Body and Affect in Medieval English Arthurian Romance', in Emotions in Medieval Arthurian Literature, 31-46.
} 
emotions ranging from joy to anger, or - as we will see below-a mixture of such positive and negative appraisals may be displayed by groups of characters at the arrival of the stranger.

\section{Positive Emotions}

The cognitive evaluation to precede affect in response to a newcomer's arrival, as addressed by Larrington for the Arthurian world, is typically signalled in Yvain by words of 'welcome' or 'unwelcome'. When Yvain arrives at the castle of Noroison this welcome schema is at play (see Appendix, Synopsis, episode IV). Having lost his lady's love, Yvain has succumbed to madness and has roamed the woods for a long period of time. One day, he is found and cured from his afflicted mind by a maiden who accompanies him to town. Although the knight has been reduced to a haggard state after having lived like a wild man, he is nonetheless 'welcomed cheerfully' by the Dame de Noroison at his arrival (Yvain, 3109-10), who shows him the greatest hospitality. She allows him to heal from his physical and mental wounds in seclusion and sends him food, drink, clothes and arms (3136-45). Yvain is therefore not introduced to the community until Count Aliers, who has declared war upon the town of Noroison, leads an attack. In the description of Yvain's arrival on the battle scene, the text foregrounds the reactions of the spectators (the community) who excitedly praise his performance and marvel at his feats:

\section{Et disorient et cil et celes}

qui el chastel remés estoient

et des batailles l'esgardoient:

'Hai, com vaillent soldoier!

Veez com fet ses anemis ploier! 
Con roidement il les requiert!

Tot autresi antr'ax se fiert

com li lyons antre les dains

qant l'engoisse et chace la fains.

Et tuit nostre autre chevalier

an sont plus hardi et plus fier

que ja, se par lui seul ne fust

lance brisiee n'i eüst,

n'espee traite por ferir.

Molt doit an amer et cherir

.i. prodome qant en le trueve.

Et tuit disoient: 'veez or comant se prueve,

veez com il se tient el ranc;

or veez com il taint de sanc

et sa lance et s'espee nue;

veez comant il les remue;

veez comant il les antasse,

com ill or vient, com il or passé.

'Veez qant il vient an 'l'estor

com il a po son escu chier;

com il le leisse detranchier;

n'en a pitié ne tant ne qant,

mes de ce se voit molt en grant

des cos vangier que l'en li done. 
Veez comant il le fet

de l'espee, qant il la tret!

Onques ne fist par Durandart

Rolanz, des Turs, si grant essart

en Roncevax në an Espaigne.

Së il eüst an sa conpaigne

auques de si fez conpaignons,

li fel de coi nos nos pleignons

s'en alast come desconfiz

ou il en remassist honiz.' (3200-46)

[And all those men and women

who had remained in the town

and were watching from the battlements said:

'Ah, what a valiant warrior!

See how he makes his enemies bow before him!

How fiercely he attacks them!

He strikes among them like

the Lion amongst the fallow deer

when hunger besets and assails it.

And all our other knights

are bolder and braver

than before, for were it not for him alone,

no lances would have been broken 
nor swords drawn for fighting.

One must love and cherish

a valiant man whenever he is found.'

And they all said: 'See now how he proves himself!

See now how he rises up in the battleline;

Now see how he stains with blood

His lance and naked sword;

See how he pursues them;

See how he drives them back,

How he charges them, how he overtakes them.

'See how little care he has for his shield

when he comes into the fray:

how he lets it be slashed to pieces;

he doesn't take the least pity upon it,

but he is the most eager to avenge

the blows that are rained upon him.

'See how he wields

his sword when he draws it!

Roland never caused such devastation

With Durendal against the Turks

at Roncevaux or in Spain.

If Yvain had in his company

a few good comrades like himself, 
the villain we deplore would leave defeated

or remain here in disgrace.']

Edward Schweitzer notes that the arrival of Yvain in the town of Noroison 'marks a new entrance into the chivalric world' and functions to restore Yvain's former status. ${ }^{389}$ Both the lady's welcome and the communal praise expressed in these lines ensure the reinstatement of Yvain's chivalric status and affirm his in-group identity. Chrétien devotes even more lines to the community's positive appraisal of the knight, as the focalisation of all those men and women is extended through the voice of the narrator, who tells us that not only did they judge him a valiant warrior, but also a worthy lover:

Et dient que buer seroit nee,

cui il avroit s'amor donee,

qui si esy as armes puissanz

et desor toz reconnoissanz,

si con cierges antre chandoiles

et la lune antre les estoiles,

et li solauz desor la lune.

Et de chascun et de chascune

a si les cuers, que tuit voldroient,

por la proesce qu'an lui voient,

quë il eüst lor dame prise

et fust la terre an sa justise.

Ensi tuit et totes prisoient

389 'Pattern and Theme in Chrétien's Yvain', Traditio 30 (1974), 145-89, at 165-66. 
celui don verité disorient.

si le rant a sesanemis

qui n'en font pas joie petite.

Mes ainz fu la novele dite

au chastel, quë il i venissent;

encontre ax tuit et totes issent. (3247-304)

[And they said that she too whom he granted

his love was born in a lucky hour,

for he is mighty in arms

and as renowned above all others

as a torch among candles

and the moon among the stars,

and the sun above the moon.

And he so won over the hearts of each and every

man and woman there, that all of them,

because of the prowess they perceived in him,

wanted him to marry their lady

and rule over their land.

Thus they praised him one and all

and spoke the truth in doing so.

When he turned him [the count] over to his enemies, their joy was boundless. 
As soon as the news reached

the town, they all came out to meet them;

everyone, man and woman alike, came forth.]

In this passage in Yvain, much attention goes out the communal feeling. The castle inhabitants who are foregrounded embody one emotive voice in their appraisal of the knight. The unified subjects of 'cil et celes' (3200) (all those), 'chascun et chascune' (3254) (each and everyone) and 'tuit et totes' $(3259,3304)$ (one and all) — man and woman alike — underline the shared agency of their praise and joy-making. Their repeated exuberance serves to highlight the valiant (valiant, 3203, 3215) and brave nature of the knight (proesce, 3256) and the joy (joie, 3301) he brings to the community. These qualities are furthermore brought to life for the audience through the deployment of heroic metaphors: in his ferocity, Yvain resembles a lion among deer (3205-8) - a metaphor that foreshadows his later identity as the knight with the lion - and in his superiority, he is compared to the epic hero Roland, celebrated for his brave and legendary deeds (3239-46).

Alternating the voice of the narrator with instances of character narration in describing a scene is a narrative strategy that has typically been assigned to Chrétien's authorship. In its set-up, Brandsma shows such a group of characters who witness events and react to them in the narrative to resemble the role the chorus (choir) takes in Greek classical tragedy. ${ }^{390}$ The presence of the chorus in a scene allowed the author to emotionally engage his audience. Brandsma coins the term 'mirror characters' to showcase the use of such marginal characters as witnesses in the text who project emotion and opinion unto the audience outside of the text. Drawing on the neuropsychological concept of 'mirror neurons', he argues that the emotional

\footnotetext{
${ }^{390}$ Brandsma, 'The Court's Emotions', 75.
} 
reactions of characters in the narrative may likewise result in kinetic empathy in the audience. $^{391}$

As in real life, sight fulfils an important function in bringing about the empathetic involvement of the audience. ${ }^{392}$ Mirror characters are, for instance, typically exploited in scenes that allow for an extended view, such as fighting scenes. ${ }^{393}$ As the events of the fight unfold, the story switches from the knight and his ordeals to the often emotively rich responses of the onlookers, that may either function to emphasise the knight's success and reputation — as is the case in the passage above — or may function to create suspense regarding the knight's fate, as we will see below.

The inviting function of these characters is also evident in the passage quoted above. Chrétien's audience is repeatedly encouraged to imagine the scene for themselves: 'Veez com(ant)..' (3204, 3216, 3217, 3218, 3220, 3226, 3237) ('See how...'). Each phase of the fight is marked by these inviting words. First, the spectators point out Yvain's contagious ferocity. They then draw attention to the relentless nature of his defence, before they go on to describe his skills with lance, shield and sword. By having the characters appear as witnesses in the text, a sense of trustworthiness about the marvels described is thus conveyed to the

\footnotetext{
391 'Mirror Characters', in Courtly Arts and the Art of Courtliness, ed. by Keith Busby and Christopher Kleinhenz (D.S. Brewer: Cambridge, 2006), 275-82. See moreover, Frank Brandsma, 'Spiegelpersonages', in Hoort Wonder! Opstellen voor W.P. Gerritsen bij zijn emeritaat, ed. by Bart Besamusca, Frank Brandsma and
} Dieuwke van der Poel (Hilversum: Verloren, 2000), 37-42; Brandsma, 'Luisteren naar de Spiegel', in Maar er is meer: Avontuurlijk lezen in de epiek van de Lage Landen, ed. by Remco Sleiderink, Veerle Uyttersprot and Bart Besamusca (Davidfonds: Amsterdam U.P., 2005), 283-301.

${ }^{392}$ See for example Christian Keysers et al., 'A Touching Sight: SII/PV Activation during the Observation and Experience of Touch', Neuron 42.2 (2004), 335-46.

${ }^{393}$ Brandsma, 'Luisteren naar de Spiegel', 288. In 'Making Joy/Seeing Sorrow', Lynch also draws attention to the importance of sight in the Arthurian romance. In this article, he discusses the extended view that is created for readers through such scenes of visual observation from a higher viewpoint for the Stanzaic Morte Arthur ('Making Joy/Seeing Sorrow: Emotional and Affective Resources in the Stanzaic Morte Arthur, Arthuriana 28.3 (2018), 33-50, at 40-43). 
audience: 'Ensi tuit et totes prisoient/ celui don verité disorient' (59-60) (Thus they praised him one and all/ and spoke the truth in doing so).

Since the narrative focus on these characters in its entirety runs for more than hundred lines, it is not altogether surprising that these passages have been abridged in their Old NorseIcelandic and Middle English translations. Both versions have been rendered in a condensed style, particularly when it comes to economising those elements in the source text that are of a repetitive and superfluous nature in favour of more fast-paced and action-oriented account. ${ }^{394}$ In Medieval Translations and Cultural Discourse, Rikhardsdottir shows the pattern of omissions and abridgements discernable for the Middle English translator to at times 'follow remarkably close to that of the Norse translator, who similarly omits scenes that slow down or impede the narrative movement'. ${ }^{395}$ It therefore seems worth investigating how both translators have dealt with the repeated emotive performances by what are essentially minor characters in Yvain. Given the abridged nature of both renditions, do correspondences exist between Ívens saga and Ywain and Gawain in the way the communal feeling is rendered and deployed and if so, do these correspondences reveal traces of secondary influences on each other?

\footnotetext{
${ }^{394}$ As noted before, Hanna Steinnun Porleifsdóttir shows this reduction to be around sixty percent for Ívens saga, ('Dialogue in the Icelandic Copies of Ívens saga', at 167). Maldwyn Mills et al. note the same percentage for Ywain and Gawain (approximately three-fifths of Yvain's length, a reduction of about twenty-eight hundred lines) ('Chivalric Romance', in The Arthur of the English: The Arthurian Legend in Medieval English Life and Literature, ed. W. R. J. Barron, Cardiff: University of Wales Press, 2001, 113-84 at 117). On the condensed style of Ywain and Gawain, see Busby, 'Chrétien de Troyes English'd', 596-613; Ywain and Gawain, ed. Friedman and Harrington, xxi-xxvi; Sir Perceval of Galles and Ywain and Gawain, ed. Braswell, 78; Gustav Schleich, Über das Verhältnis der mittelenglischen Romanze Ywain and Gawain zu ihrer altfranzösischen Quelle, Wissenschaftliche Beilage zum Programm des Andreas-Realgymnasiums zu Berlin (Berlin: R. Gaertner, 1889). On the condensed style of Ívens saga, see Bornholdt, 'Old Norse-Icelandic Transmission', 100; Pórir Óskarsson, 'Rhetoric and Style', in A Companion to Old Norse-Icelandic Literature and Culture, ed. Rory McTurk (Oxford: Blackwell Publishing, 2005), 354-71, at 367.

${ }^{395}$ Rikhardsdottir, Medieval Translations and Cultural Discourse, 97.
} 
In Ívens saga, we likewise witness the course of the battle through the eyes of spectators upon the castle walls, albeit through a greatly reduced focalisation. While the community is ascribed an individual narrative focus in Yvain, the focal point in Ívens saga is initially with the lady who is accompanied by her people.

Í penna tíma gekk sú fríða frú upp í vígskörð kastalans ok mart fólk með henni at sjá penna bardaga. 'Sé', sögðu peir í kastalanum váru, 'hversu pessi riddari gengr fram einn fyrir alla, eða hversu hans herklæði eru lituð í blóði peira er hann hefir drepit, eða hversu hann gengr ígegnum lið peira.' (70)

[At this time the beautiful lady went up to the battlement of the castle as did many people with her to watch the battle. 'See', said those within the castle, 'how this knight presses forward in front of all others, and how his armour is coloured with the blood of those he has killed, and how he presses forward into their ranks.]

The admiration voiced by the lady and her people is reduced to a single performance in Ívens saga, which is an extremely condensed account of the first two focalisations of the community in Yvain. The knight's persistence in renewing the attack is completely omitted. Although the extradiegetic audience is invited to see for themselves, the mirroring function of the lady and her people is cut short as the narrative switches from character narration through direct speech to the indirect voice of the narrator, who continues the account:

Ok svá hjuggu peir vandliga skjöldinn af honum, at ekki beið eptir. En hverr af peim, er nokkut högg hjó í hann, pá hefndi hann svá vaskliga, at eigi fysti pann optar til hans at höggva, pvíat hann svefðiz svá pungum svefni, at engi hans kumpánn fekk vakit 
hann. Skem sjöldrinn ónyttiz fyrir honum, pá tók hann spjótit ok braut svá mörg fyrir sínum óvinum at vel váru níu tigir fyrir kveld. Ok var pat mest mannspel óvinum hans er hann gerði með spjótinu. En á millum pess er hann braut spjótit ok til pess er hann fekk annat, pá neytti hann sverðsins. (72)

[And they hacked at his shield in such a way that nothing remained. And against each one who struck blows at him, he avenged himself so valiantly that his opponent no longer had any desire to strike at him, for he fell in such a deep sleep that none of his companions could awaken him. When his shield had become useless he took lance and broke so many against his enemies that they easily numbered ninety before evening came. And it was an exceedingly great destruction of his enemies that he wrought with his lance. And between breaking one lance and reaching for another he uses a sword.]

Yvain's emotive script for emotionally steering the audience in their appraisal of the knight through the inviting function of the community in the text is thus not fully exploited at this point in Ívens saga. Although likewise directed at his bravery (vastkliga, 70) and his superiority as a knight, the words of praise by the community in Yvain are ascribed to the voice of the narrator. Despite the overall streamlining of the scene, the Old Norse translator diverts at this point from his/her source and invests a few lines to familiarise his audience with knightly combat and the skill in bearing arms. ${ }^{396}$

Whilst it is possible that the inviting function of the onlooking community may not have been recognised by the Norse translator as a narrative strategy, his/her modifications

\footnotetext{
${ }^{396}$ A similar deviation, albeit much more extensive digression on knightly combat may be found in Parcevals saga. When Parceval visits Gormanz of Groholl, he is instructed by his host how to ride a charger and on the proper order of bearing arms (122-28, especially 126). The rules of chevalerie, literally 'horse-soldiery' in Old French, may not just have been unconventional to the naive Parceval, but perhaps also to the Nordic audience.
} 
may also indicate a more conscious mediation between Yvain's emotive script for the emotive engagement of the audience and a more traditional narrative style that would have favoured a more fast-paced narrative sequence. Nicola Jordan notes that direct speech spoken by secondary characters is generally changed to indirect speech in Ívens saga, or is otherwise omitted. ${ }^{397}$ In the case of repeated direct voice, it is mostly fused together, resulting 'in the participants speaking fewer times than in the original', as has been argued by Hannah Porleifsdóttir, and which seems to have occured here. ${ }^{398}$

In light of this, it is all the more surprising that Ívens saga switches to direct speech again at the exact point in the narrative where the Old French source turns to indirect speech (to compare passages, see Yvain 3236-59). In Yvain, the indirect speech is an extension of the voices of 'all the man and women', whereas in its Old Norse-Icelandic translation we find not only a negotiation of speech, but also of gender:

Sem meyjar kastalans líta hann í bardaganum, at hann var svá einkanliga hraustr riddari, pá mæltu pær: 'Sæl væri sú er svá dyrligum riddari stenz hefði fengit sína ást, pvíat hann er svá máttugr í vápnaskipti at engi riddari stenz honum. Svá er hann einkanligr fyrir aðra riddara, sem rautt gull fyrir eiri, eða sólar geisli fyrir tungls ljósi. Guð láti oss pat bíða’, sögðu pær, 'at hann væri várr ok várrar frú ok réði öllu ríki hennar.' (72, my emphasis)

[When the maidens in the castle look upon him in battle and see that he is such an extraordinarily valiant knight, they spoke: 'Blessed is she who has given her love to such a splendid knight, for he is so powerful in combat that no knight can withstand

\footnotetext{
${ }^{397}$ Jordan, 'Eine alte und doch immer neue Geschichte', 148.

${ }^{398}$ Porleifsdóttir, 'Dialogue in the Icelandic Copies of Ívens saga', 172.
} 
him. He is as superior to other knights as gold is to iron, or the radiance of the sun to the light of the moon. May God grant us,' they said, 'that he becomes our lord and our lady's lord and rules over her entire realm.']

The words of praise - up until this point in the narrative largely absent in the scene compared to the French source - are now voiced by the maidens in the castle. Their description of the superior nature of the knight is stronger than the narrator's at this point in Yvain. Rather than being 'as armes puissanz' (3249) (mighty in arms) and 'reconnoissanz' (3250) (renowned), he is 'einkanliga hraustr' (extraordinarily valiant), 'dyrligur' (splendid) and 'máttugr' (powerful). Notably, Chrétien's metaphorical elaboration on the knight's superiority is also rendered in Ívens saga, albeit slightly adapted, whereas the Norse translator otherwise generally omits metaphorical ornamentation, as we have seen in chapter one. The reference to the winning over of the hearts of those present (Yvain, 3254-55, literally 'the having of their hearts') is however not rendered in translation, a textual mediation that is in line with the overall circumvention and omission of Chrétien's intercorpeal metaphors of the heart-a heart that is not confined to its body, but may be given to reside with another - assigned for Ívens saga in chapter one (see section 'The Itinerant Heart Motif', pp. 121-28 of this study).

The gender specification of the female community, who have a clear mirroring function here, is even more striking when we consider the Old Norse-Icelandic translation of the final reference to the castle inhabitants. When Íven chases and ultimately seizes the fleeing earl, the Norse translator follows the French source again in ascribing 'the great joy' (miklum fagnaði) they made at their enemy's capture to 'a large group of men and women' (miklum fjölda karla ok kvenna) who welcome him. A deliberate negotiation thus seems to have taken place regarding the groups of characters in appraisal of the knight. This is also suggested by the reformulation of the Old French 'Et dient que buer seroit nee/ cui il avroit 
s'amor donee' (3247-48, my emphasis) (And they said that she too whom he granted his love was born in a lucky hour) into Old Norse 'Sæl væri sú er svá dyrligum riddari hefði fengit sína ást' (72, my emphasis) ('Blessed is she who has given her love to such a splendid knight'). The Norse translator transforms male agency into female when it comes to the granting of love. This subtle reformulation falls into place when we recall the obstacles pointed out by Bandlien when it comes to reconciling the emotional codes of courtly love with the representation of love according to traditional saga convention (see chapter one, at 80-81). Saga convention promotes a different love ideal in which men are not supposed to be weakened by feelings for women. Instead, it favours a heroic portrayal of love by foregrounding the love and the honour a woman should bestow upon a man. ${ }^{399}$ Both this shift in agency and the gender negotiation in voice described - the specification of the female community in praise of the knight — serve to underline the sense of admiration in the maidens as they watch Íven fight, thus affirming his masculine honour in the scene.

Although the description of the battle through the eyes of the spectators is also streamlined in Ywain and Gawain, the scene establishes a clear in-group identity for the knight. The narrative perspective remains with those witnessing the fight and is rendered completely in direct speech. The focalisers, however, have been altered. Rather than all the men and women on the battlements, the extradiegetic audience witnesses Ywain's prowess and the course of the battle through the eyes of the lady herself and her maiden:

The lady lay ever and bihelde;

Sho sais, 'Yon es a nobil knyght,

Ful eger and ful grete myght;

He es wele worthy forto prayse,

\footnotetext{
${ }^{399}$ Bandlien, Strategies of Passion, 127, 193.
} 
That es so doghty and curtayse.'

The mayden said, 'Withowten let, [doubtless]

Yowre oynement may ye think wele set; [ointment; well applied]

Sese, madame, how he prikes, [See, spurs]

And sese also how fele he stikes [many]

Lo, how he fars omang his fase; [foes]

Al that he hittes sone he slase. [slays]

War thare swilk other twa als he,

Than, hope I, sone thaire fase sold fle.

[foes]

Sertes, than sold we se ful tyte, [quickly]

The eril sold be descumfite.

[overcome]

Madame, God gif, his wil were

To wed yow and be loverd here.' (1892-1908, my emphasis)

The appraisal of the knight has been ascribed to more prominent and/or more familiar characters, which may also have motivated the Old Norse translator to incorporate the lady in the scene. The focalisation in Ywain and Gawain is first with the lady, who, even before the individual deeds of arms have been witnessed, speaks very highly of the knight. Words in assessment of the knight are solely reserved for the lady, which may explain why such praises have been moved forward in the scene compared to the passage in Yvain. Shannon McKie notes that the English poet paid more attention to hierarchy than Chrétien and that rank and appraisal are more strongly linked in Ywain and Gawain. ${ }^{400}$ The lady's positive judgment of

\footnotetext{
${ }^{400}$ La hierarchie et l'adaptation: comparaison entre 'Yvain' et 'Ywain and Gawain', PhD dissertation, University of British Columbia, 2002. McKie also notes that the lady of Noroison is ascribed a more prominent role in the discovery and identification of Ywain in the forest (19-20). See moreover Busby, who likewise
} 
the knight is, at this point in the scene, stronger than the words of praise voiced by the community in either Yvain or Ívens saga. Ywain is 'nobil', 'ful eger and ful grete myght', and 'doghty and curtayse' (1893-96).

The second narrative focus in Ywain and Gawain - which in Yvain remains with the community and in Ívens saga goes out to all the maidens - is with the maiden who cured the knight of his madness before he came to Noroison, which the audience is reminded of in the text. It is the maiden who underlines Ywain's chivalric actions and suggests him as a husband to the lady. However, rather than serving a mirroring effect, direct speech takes on the form of a dialogue in the Middle English passage. Since the maiden is addressing her lady, the invitation to marvel at the knight's deeds ('Sese, madame', 1899) is not extended to the extradiegetic audience.

Despite the favouring of more prominent/familiar characters in praise of the knight, the joy expressed at the capture of the earl is, likewise to Yvain and Ívens saga, ascribed to the community by the Ywain-poet: 'In the kastel made thai joy ilkane,/ When thai wist the eril was tane./ And, when thai saw tham cumand nere,/ Ogayns him went thai al infere.' (193740).

\section{Negative Emotions}

A different arrival schema is at play when Yvain travels to the kingdom of Landuc (Appendix, Synopsis, episode II). Having set out to avenge Calogrenant's shame, Yvain comes upon the mysterious fountain, the onset for his cousin's misadventure. Like Calogrenant, he takes water from the basin and pours it over the stone. Immediately, he is

argues that Ywain and Gawain reflects a focus on status and hierarchy, 'in which all ranks receive the respect they are due in the natural order of things' ('Chrétien de Troyes English'd', 604 ). 
challenged by Esclados the Lord of the Fountain in single combat, a fight that proves to be to the death as Yvain mortally wounds his opponent. When Yvain pursuits his wounded adversary into the castle of Landuc, a hidden portcullis traps him inside. From his first moment of arrival, a clear outsider status is established for Yvain in relation to this new community: a negative arrival schema is at play as Lunete, who suddenly appears through a tiny door, makes it explicit that the knight is 'not welcome': 'je criem que mal soiez venuz' (979).

The maiden continues by describing the hostile scene that is unfolding upstairs. By mortally wounding the Lord of the Fountain, Yvain has not only taken away a husband from a wife, but more importantly, a lord from his subjects. In Lunete's account, the focus is on the display of emotion of Esclados's subjects, who are weeping and on the verge of killing themselves. Although the grief of the lady herself is specified in a long monologue a few lines down, Yvain is initially confronted with the communal feeling, as Lunete explains:

\footnotetext{
'Ma dame an fet i. duel si fort et ses genz anviron lui crient, que par po de duel ne s'ocient; si vos sevent il bien ceanz. Mes entr'ax est li diax si granz quë il n'i pueent or entandre; s'il vos voelent ocirre ou pandre, a ce ne pueent il faillir
} qant il vos voldront assaillir.' (984-92; my emphasis) 
[My lady is grieving so deeply

and her people are weeping around her so much

that they nearly kill themselves for grief

and they all know you are here within.

But the grief they share is so great

that now they cannot think of anything else.

When they wish to kill or hang you,

they'll not fail to do so

as soon as they choose to attack you.']

Lunete's words of warning are a clever way for the author to manage his audience's anticipations. Through the character of Lunete, Chrétien is able to present his audience with a taste of what awaits the knight. Although it is clearly stated that their sorrow delays the anticipated reaction of the people, this at the same time further intensifies a sense of foreboding of what is to come: should they find him, they will not fail to kill him (991).

The suspense that is created by delaying the moment of the courtiers' attack is addressed by Rushing with regard to the visual representation of the entrapment scene in $\mathrm{BN}$ fr. 1433's miniature cycle. ${ }^{401}$ The first of the so-called Paris illuminations narrates the sequence of events of Yvain's defeat of Esclados and his imprisonment in the castle (see Appendix, Images, image 2). On fol. 69v we see the depiction of the scene of Yvain being visited by Lunete (see image 3). A variety of important details narrate the scene. Lunete sternly raises her index finger in warning and Yvain appears intimidated and has his sword drawn, while from either side of the room mailed heads peer into the scene, representing the search for Yvain going on outside. Rushing believes the depiction of Yvain's entrapment to

\footnotetext{
${ }^{401}$ Rushing, Images of Adventure, 178-79.
} 
assist in 'initiating a new narrative sequence' as it invites the question: 'How will Yvain's predicament be resolved? More generally, will his defeat of Esclados have positive or negative outcomes for Yvain? ${ }^{402}$ Indeed, it seems there is nothing left to do for the knight but to put his life into the hands of providence:

'se Deu plest, ne m’ocirront ne ja par aus pris ne serai.' (994-95)

['If it pleases God, they never will kill me, nor will I ever be captured by them.']

Where in the French source there is a clear narrative focus on the courtiers' grief, the display of individual emotion seems to be favoured over the communal feeling in the Old NorseIcelandic translation. The intense sorrow ascribed to Esclados's subjects in Yvain 'as they nearly kill themselves with grief' is directed towards the grieving widow in Ívens saga, as Lúneta informs us that, first and foremost, her heart is nearly breaking with grief':

'Mín frú hefir fengit mikinn harm ok allt lið hennar, pat hjá henni sitr, svá at náliga springur af harmi. Allir vita at pú ert hér í höllinni. En peir mega eigi drepa pik fyrir harmi eða höndum taka pvíat pú ert í peira valdi nær sem peir vilja pik höndum taka.'(49)

['My lady has suffered great distress, as have all her people who are sitting with her, so that her heart is nearly breaking of grief. Everyone knows that you are here in the

${ }^{402}$ Ibid. 
hall. But they cannot harm you or seize you because of their grief, but you are in their power whenever they want to take you prisoner.']

The threat posed by the community is toned down in Ívens saga. Not only is their grief redirected towards Esclado's widow, but Lúneta's assessment of the situation is also less dire. Instead of warning against an attack on the knight's life (Yvain, 995), she cautions against imprisonment. Although the prefigured threat is, likewise to Yvain, delayed due to the household's grief, the worst they will be able to do is to harm or seize him, as opposed to the more violently inspired actions of killing and hanging alluded to by Lunete in the French source. Such allusions to the killing of the knight-protagonist are either omitted or reformulated in the Old Norse-Icelandic translation. Yvain's response to Lunete's warning, '[i]f it pleases God, they never will kill me, nor will I ever be captured by them' (994-95, above), becomes 'aldri skulu peir pví hrósa, at peir taki mik höndum (48) ('they shall never be able to boast that they have taken me prisoner'), suggesting more strongly that it will not happen. Unlike Chrétien, who builds suspense in the scene by playing on his audience's anticipations, the Old Norse translator suppresses the invocation of any feelings of doubt or unease regarding the knight's fate.

In fact, the state of fear is negated for Íven. After Yvain's call upon providential guidance, Lunete continues that she will do everything in her power to help protect the knight and gives him 'a little pep talk' to inspire courage:

N'est mie prodom qui trop dote:

Por ce cuit que prodom soiez que n'iestes pas trop esmaiez. (998-1000, my emphasis) 
[He is not worthy who fears too much;

but since you have not been too frightened,

I believe you are a worthy man.]

Michael Ovens notes hat Lunete's equivocal phrasing in this passage foreshadows Yvain's fear: '[t]he repetition and negation of 'worthy man' in these lines, coupled with the endrhymes on 'soiez' (you are) and 'esmaiez' (frightened), creates a sense of irony and ambiguity'. ${ }^{403}$ Perhaps having felt the need to rid the narrative of Lunete's ambiguous observation regarding the knight's courage, the Norse translator clarifies that the knight is not afraid and it is suddenly now that the severity of the situation ís adressed: 'ekk hygg at pú [s]ér dugandi maðr er pú óttaz ei pott pú sért ognliga niðr komi[inn'] (48) ('I think you are a courageous man, since you are not afraid even though you are in a terrible spot'.) $)^{404}$

Right at the moment in the narrative when suspense starts to build again as Lunete's warning is about to become real, the existence of fear in the knight is negated once more in the Old Norse rendition. When Esclados finally succumbs to his fatal wounds, Laudine's household is propelled into action. ${ }^{405}$ As those who Lunete warns against as 'hostile and

\footnotetext{
403 'Violence and Transgression in Chrétien's Yvain', Parergon 32.1 (2015), 53-76, at 62. I follow Ovens in his translation of prodom that diverts from Kibler's, whose translation obscures the repetition of the term.

${ }^{404}$ On Lunete's ambiguous phrasing, see Green, Irony in the Medieval Romance (Cambridge: Cambridge University Press, 2003), 174-75.

${ }^{405}$ Although this is not entirely clear in Yvain, the actual death of the lord seems to have been delayed to this moment, as time itself is warped throughout the scene, presumably in order to facilitate the intensification of collective mourning and rage and the building of suspense. Jenefer Robinson notes that passages that are subject to suspense are generally marked by a deceleration of the narrative pace (Deeper than Reason: Emotions and its Role in Literature, Music, and Art, Oxford: Clarendon Press, 2005, 124). By having the dead knight's wounds bleed anew a few lines down, the scene allows for even more suspense to build. Curiously, in the Old Swedish rendition of the passage it is made clear even before Ivan is imprisoned in the castle that Vadein has died, as we are told that he falls dead from his horse ('pa styrte han døper af hæstin niper' (800)) while he addresses his people: Iak ma mik sare for Iper klagha:/en ridare mik hær æptir iaghæ/han haver mik sva sare skænt/ pæt mit lif
} 
troublesome people' (gent molt enuieuse et male, 1068) start milling around, making 'a lot of noise and commotion' (grant noise et grant bruit, 1062) in search for the knight, she leaves Yvain with these words:

\author{
'Si seroit solaz et deliz \\ a home qui peor n'avroit, \\ qant gent si avuglez verroit: \\ qu'il seront tuit si avuglé, \\ si desconfit, si desjuglé, \\ quë il anrageront tuit d'ire, \\ je ne vos sai ore plus dire, \\ ne je n'i os plus demorer.' (1074-80)
}

['It will be an amusing sport

to a man who is unafraid

to see people so blinded,

so confused, so deceived,

that they'll be beside themselves with rage;

I have nothing more to tell you,

Nor will I stay here any longer.]

\begin{abstract}
Although it is of course possible that Lunete's departing words to Yvain are to be taken at face value, her casual, almost playful phrasing suggests that they operate on another level of
\end{abstract}

ær nu braplike ænt' (795-98) (I must complain bitterly to you: a knight is pursuing me here; he has injured me so badly that my life will soon be over now). 
meaning. The ambiguous manner in which she delivers the speech above gives rise to the question 'what kind of experience (sport) will it be to the man who is afraid?'(1074-5) in Yvain's, and perhaps also the audience's mind. This type of playfulness is often assigned to the character of Lunete. Peter Haidu, for instance, notes that on several occasions Lunete amuses herself at Yvain's expense. ${ }^{406}$ Dembowski suspects the 'voice' of Chrétien behind Lunete's verbal irony. ${ }^{407}$ Although we lack documentary evidence about how Chrétien's stories were actually presented to audiences, it is generally assumed that his romances were aimed at provoking judgement and encouraging debate and there is much evidence to suggest that recitations involved audience responses. ${ }^{408}$

In addition to serving comical ends, Lunete's words also seem to call upon a sense of empathy for the knight's fate in the audience, as is pointed out by Gillian Adler. She notes how Lunete's involvement in the entrapment scene 'aids in reconstructing Yvain's reputation after having mistakenly killed the Lord of the Fountain'. ${ }^{409}$ Indeed, duels are not often to the death in Chrétien's romances and defeated knights are generally taken prisoner or sent to surrender to Arthur's court. When we interpret the slaying of Esclados, like Adler suggests, as a transgression on Yvain's part, the courtiers' anger is justified, as is Yvain's fear. The eventual restoration of the social and political unity upended by Yvain's arrival is in fact contingent upon these two negative emotions. While the people's rage may be sincere, it is also future-oriented as anger serves here as a necessary prelude to joy. Rikhardsdottir similarly addresses the remedial function of the courtiers' anger:

\footnotetext{
406 'Narrativity and Language in Some Twelfth Century Romances', Yale French Studies 51 (1974), 133-46, at 139.

${ }^{407}$ Dembowski, 'Monologue, Author's Monologue and Related Problems', 102-14. See moreover, Green, Irony in the Medieval Romance, chapter 6 'Verbal Irony', 171-212.

${ }^{408}$ See for instance Kelly, Chrétien de Troyes, 145, 156, 162.

409 'Female Intercession and the Shaping of Male Heroism in the Roman d'Enéas and Le chevalier au lion', Medieval Feminist Forum: A Journal of Gender and Sexuality 49.2 (2013), 70-87, at 77.
} 
While the sorrow may be perceived as authentic, it would nevertheless be intended and understood as an act of homage, a socially prescribed gesture of feudal fidelity [to Esclados]. Such an interpretation of the scene would explain the rapid recuperation of both Laudine and her people once a new lordship has been established and new feudal allegiance guaranteed. ${ }^{410}$

The emotional dynamism of narrative is further examined by Lynch for Arthurian romance. In 'Positive Emotions', he writes: '[E]motions mobilise action and are further mobilised by it'. ${ }^{411}$ Drawing on Frijda's concepts of appraisal and action readiness, Larrington connects this sense of movement ('motive') to 'motivation' in her discussion of literary emotions: 'Emotion does not occur without a proximate cause, and it results in some action; it often appears in the text to explain motivation": "emotions arise out from the interaction of situational meanings and concerns". ${ }^{412}$ When we view the courtiers' anger in terms of the story's motivation, we can conclude that the people need to properly mourn their old lord before they can allow Laudine to remarry and accept Yvain as their new lord. Likewise, Yvain needs to experience fear to come to terms with the consequences of his transgression and, ultimately, to compensate for his offensive action. His fear motivates not only his successful restoration of lordship to the land of the Fountain, but is moreover critical for the restoration of his own knightly reputation both in the text and in the eyes of the audience. Indeed, when the angry

\footnotetext{
${ }^{410}$ Rikhardsdottir, 'Translating Emotion', 175-76.

${ }^{411}$ Lynch, 'Positive Emotions', 57.

${ }^{412}$ Larrington, 'The Psychology of Emotion and Study of the Medieval Period', 254, citing Nico Frijda, 'The Laws of Emotion', American Psychologist 43 (1988), 349-58, reprinted in Human Emotions, ed. Jennifer Jenkins, Keith Oatley and Nancy L. Stein (Oxford: Wiley-Blackwell, 1998), 270-80, at 274.
} 
crowd finally gives up its search, Lunete returns to Yvain with the question whether he was afraid and he now acknowledges:

\author{
'Par foi', fet il, 'vos dites voir; \\ ja si grant ne cuidai avoir.' (1264-70) \\ ['In faith', he said, 'you speak the truth; \\ I never thought I'd be so afraid.']
}

Note that, although Yvain's fear is already prefigured in Lunete's ambiguous phrasing, it is left to the knight himself to confess his fear.

This confession is omitted in Ívens saga. What is more, the ability of the household to do the knight harm seems to have been played down. Íven is not confronted by Lúneta with the 'hostile and troublesome' nature of the courtiers, adjectives that go untranslated in Ívens saga. Íven instead hears 'a great hue and a cry that their lord was dead' (mikit óp ok kall at herra peirra var dauðr, 50)—group behaviour associated with grief and of a less threatening nature than the rage displayed by the crowd in Yvain — and the maiden leaves the knight saying:

'Pu munt sjá pá er pín leita, at peir fara sem ærrir men ok sjá ekki, ok er pér pat mikil skemtan pvíat pú ert eigi hrceddr at sjá pá blina ok örvita.' (50, my emphasis)

['You will see those who are looking for you, and that they are moving about like mad men and don't see you. That will amuse you, since you are not afraid to watch them blinded and senseless. But now I shall have to go.'] 
There is no hint of irony or ambiguity in Lúneta's departing words. The fact that the knightprotagonist is not afraid is presented as a given in Ívens saga. This reformulation reveals an engagement with Yvain's emotive script that may well be in keeping with the observation that has been made for many Norse translations of French romances that indicators in criticism of the hero and/or of weaknesses in his character are either omitted or toned down.

Both Nicola Jordan and Claudia Bornholdt have noted that judgements on the part of the narrator or by other characters in Ívens saga are blended out to avoid the portrayal of weaknesses in main characters. ${ }^{413}$ In a similar manner, inner conflicts and inner progression of the individual characters are toned down while their actions are emphasised. Bornholdt ascribes such redirections to '[t]he central role that is allotted to the hero's reputation, his honour and personal freedom', values that are 'deeply rooted in medieval Icelandic literature and culture'. ${ }^{414}$ She illustrates this with a comparison of the depiction of King Arthur in Yvain and Ívens saga and shows the latter to tone down instances of criticism regarding the king. When Gawain's uncle explains to Yvain that they received no help from Arthur's court in defending the kingdom against the giant Harpin de la Montaingne due to Guinevere's

\footnotetext{
${ }^{413}$ Jordan, 'Eine alte und doch immer neue Geschichte: Die Ívents saga Artúskappa und der Iwein Hartmanns von Aue als Bearbeitungen von Chrétiens Yvain', in Übersetzen im skandinavischen Mittelalter, ed. Vera Johanterwage and Stefanie Würth, Studia Medievalia Septentrionalia 14 (Vienna: Verlage Fassbaender, 2007), 141-66, at 158-59; Bornholdt, 'The Old Norse-Icelandic Transmission of Chrétien de Troyes’s Romances', 108-9. See moreover, Kjær, 'Franco-Scandinavian Literary Transmission in the Middle Ages', 124; Bernd Kretschmer, Höfische und altwestnordische Erzähltradition in den Riddarasögur: Studien zur Rezeption der altfranzösischen Artusepik am Beispiel der Erex saga, Ívens saga und Parcevals saga (Hattingen: Verlag Dr. Bernd Kretschmer, 1982), 150.

${ }^{414}$ Bornholdt, 'The Old Norse-Icelandic Transmission of Chrétien de Troyes's Romances', 111. See also Kalinke, 'Honor: The Motivating Principle of the Erex saga', Scandinavian Studies 45.2 (1973), 135-43.
} 
abduction, he calls King Arthur a fool and the queen imprudent (3920). The Norse translator omits the criticism aimed at the king and merely calls the queen unwise. ${ }^{415}$

Jordan also notes that the Old Norse-Icelandic rendition removes or reformulates those sentiments that discount Arthur's reputation and status as king. She explains the tempering of these anti-sentiments to omit the impression invoked in Chrétien that Arthur would not be in control of the situation. ${ }^{416}$ The characterisation of Íven seems to undergo a similar transformation in this scene. The suspense that builds in Yvain due to the foregrounding of communal anti-sentiments in combination with the narrator's play on the audience's expectations through the character of Lunete, is tempered in Ívens saga, which seems to favour a hero whose honour remains intact according to the masculine ideals of saga conventions. $^{417}$

This may explain why the focalisation of the raging courtiers is further played down in the Old Norse-Icelandic rendition as the hunt for the knight continues. Having gathered with clubs and swords in hand (bastons et espees, 1090), the angry mob in Yvain starts upending the castle as one emotive body 'of cruel and hostile people' (de gent felenesse et angressse, 1091). Again it is stressed that they 'would have gladly killed him' (1108), but since they can't see him because of the invisibility ring they 'grow more and more mad with rage and anger' (anragier; forssener et correcier):

\footnotetext{
${ }^{415}$ Ibid. 108-9. The same redirection has been illustrated by Sullivan for Hoerra Ivan: 'The Old Swedish poet removes the implications that Arthur has contributed to Guinevere's kidnapping . . . and makes Guinevere's abduction something that happens to Arthur and not something that the king helps orchestrate' ('Arthur of the Northeast', in Arthur of the North, special issue of Scandinavian Studies 87.1 (2015), 33-61, at 49).

${ }^{416}$ Jordan, 'Eine alte und doch immer neue Geschichte', 158-59.

${ }^{417}$ See Bornholdt, "“Everyone thought it very strange how the man had been shaped": The Hero and His Physical Traits in the Riddarasögur', Arthuriana 22.1 (2012), 18-38, in which she argues that 'the Norse adaptors of the continental sources altered characters and scenes in order to conform to certain expectations of their Scandinavian audience-expectations that were undoubtedly derived from a heroic ideal.' (21).
} 
Puis firent traire amont les portes

Par coi maintes genz furent mortes.

Mes onques entr'ax n'orent oel

don mon seignor Yvain veïssent

que molt volentiers oceïssent;

et il les veoit anragier

et forssener et correcier.

Ensi trestuit d'ire eschaufé

Parmi la sale les paroiz feroient,

Et parmi liz, et parmi bans

et molt randirent grant estor

par tot leanz de lor bastons,

com avugles qui a tastons

va aucune chose cerchant.

et dist chascuns et cil et cist;

'Entre nos est cil qui l'oscist,

ne nos ne le veomes mie

cë est mervoille et deablie!' (1099-1202, my emphasis)

[Then they had the portcullis, which had been 
the death of many people, hauled up.

But not one of them had an eye

sharp enough to see my lord Yvain

whom they would have gladly killed

and he saw them going mad

with rage and anger.

Thus enflamed with anger, they all

sought for him within the room,

striking through the walls

and the beds and the benches

and they struck all around

and made a tremendous uproar

with their clubs everywhere in the room,

like a blind man who taps along

as he looks for something.

man and woman, each and everyone of them said:

'Among us is the one who killed him,

yet we do not see him at all;

This is a wondrous and devilish thing!'] 
In Ívens saga, the household is less mob-like and the thread of the community is less imminent. Except for the 'great fury' ascribed to the people, there is no excessive show of anger in translation. Overall the courtiers are rendered more civilised than their counterparts in Chrétien's text. Adjectives like 'cruel' and 'hostile' have been omitted in their description. Although the people are armed, they only carry swords (sverðu, 50), but no clubs, an object usually associated with a more primitive character (giants, devils, dwarfs) rather than a knightly opponent in medieval literature. ${ }^{418}$ The manhunt, that is later described by Lunete as 'more persistent than a hound on the scent of a partridge or quail' (1264-67), is not as unrelenting compared to the French source:

Peir fóru leitandi ok fundu hann eigi. Peir undu upph hurðina er mörgum manni hafði illt gert ok hittu peir hann eigi par. Peir gengu pá inn í höllina leituðu hans með fullum grimmleik... Ok fóru enn at leita hans af nýju. Pá leita peir hans um alla höllina ok í sængunum ok undir fótskörunum. (50, my emphasis)

[They went around searching but did not find him. They raised the portcullis that had harmed many a man but they did not find him there. They went into the hall and searched for them with great fury ... And they started to look anew for him. They searched for him throughout the hall and in the bed and under the footboards.]

\footnotetext{
${ }^{418}$ See for instance Helmut Bonheim, 'The Acromegalic in Chrétien's Yvain', French Studies 44.1 (1990), 1-9. Bornholdt discusses redirections from the Old French source in Erex saga that are of a similar nature. She argues, for instance that the dwarf Guivret in Erec et Enide is modified in Erex saga into a more appropriate opponent for Erex who is 'large and strong'. See moreover Bornoldt's discussion of Morhold's adapted character in Tristams saga, who unlike Gottfried's Morolt fights in a knightly fashion, with a sword instead of a club and on horseback ('The Hero and His Physical Traits', at 28, 32). Note that the choice of weapons by Chrétien is also amended by the Swedish translator. Next to 'sværp' (sword), 'sume hafpo bogho ok sume stang' (915-16) (some men had bows, others had poles).
} 
Like the Old Norse-Icelandic rendition, the Middle English version abridges the episode of the grieving household of Landuc. Unlike in Ívens saga, however, suspense and anticipation management are still clearly at play in Ywain and Gawain as it closely follows its French source's emotive script, despite the streamlining of the passage. The hostile and murderous intent of Salados' subjects, here clearly positioned as 'foes' (famen, 708), establishes a strong outsider status for the knight. Likewise to the anti-community in Yvain, they mean to kill him 'to be thi bane er thai ful balde' (709), a threat that is further intensified as it is added in Middle English that there is no escape for 'he cannot break out, nor will his foes fail to slay him' (710-11):

'My lady makes sorow ynogh

And al his menye everilkane

Here has thou famen many ane [foes]

To be thi bane er thai ful balde. [to cause your death are; eager]

Thou brekes noght out of this halde [there is no escape]

And, for thai thai wate thai may noght fayle [since they know]

Thai wil the sla in playn batayl.' (706-12, my emphasis)

Since he finds himself in dire straits, Ywain likewise is left with no other resource than to put his fate in the hands of God: 'He sayd, 'Thai ne sal, so God me rede [shall not; counsel]/ For al thaire might do me to dede, [slay me]/ Ne no hands opon me lay' (706-15). Unlike Ívens saga, in which the threat of the courtiers is played down in comparison to Yvain, the hostility of the community is played up in Ywain and Gawain. When Lunet leaves the knight, she finds awaiting an angry mob who are specified to be men-implying that the vengeful group 
represents the lord's retainers rather than his household ${ }^{419}$ — who are 'well-armed' (type of weapons not specified) and 'eager to take and slay Sir Ywain':

Ful many men fand sho tharate

Wele armed, and wald ful fayn

Have taken and slane sir Ywaine. (792-4)

Although the group is not specifically described to be hostile and troublesome-adjectives that have been pointed out for the scene in Yvain - this is certainly implied by their constant baying for blood (708-9; 765-66), as their murderous intent is repeated once more: 'Mekyl sorow thai made ilkane, [each one]/ For thai ne myght wreke thaire lord bane' [avenge; lord's death] $(815-16)$.

Whereas in Ívens saga the killing or hanging of the hero of the story by what are essentially minor characters in the narrative is not presented as a possibility, in Ywain and Gawain we find the opposite, as imprisonment does not seem to be an option. Although their frenzied state cannot be inferred from emotional lexis, as is signalled in Yvain with 'anragier et forssener et correcier' (1109-10), it is apparent in their actions, as they strike around so hard, with blows so powerful that many of their weapons broke: 'Al obout thai smate so fast/ That mani of thaire wapins brast' (813-14).

Similar to Yvain, the character of Lunet is deployed to steer the audience in their assessment of the situation in the Middle English story. The narrative focus switches from the vengeful retainers who make 'grete noyse' (764) upstairs once their lord has died to the trapped knight who is comforted by Lunet: 'be thou never te more adread' (771) ['don't be

\footnotetext{
${ }^{419}$ Ywain and Gawain, ed. Friedman and Harrington, xxviii.
} 
afraid']; 'be of hert lyght' (781) 'bet thou noght aferd' (784); 'drede the noght' (788). ${ }^{420}$ Ambiguity can also be assigned to the English Lunet's voice, as her repeated reassurances serve to comfort the knight within the narrative, but in fact highlight the frightfulness of the situation for the audience outside of it. Like in Yvain, the knight's fear is implied on such occasions, but never directly witnessed by the audience until after the threat has subsided. There is, moreover, similar ambiguous phrasing - Al if thou be here straytly stad, [sore beset]/ Me think thou ert noght ful adrad' [completely afraid] (717-18) —although, unlike the French source, this does not seem to be in the service of irony. In 'Chrétien de Troyes English'd', Busby notes that 'Lunet's playful teasing is absent in Ywain and Gawain', which he connects to the overall 'reduction in the submissiveness of men to women': 'Lunet is not allowed to be as disrespectful towards Ywain as Lunete is towards Yvain, and this has as much to do with her social status as her gender.' ${ }^{421}$

Ultimately, however, when Lunet returns to Ywain and asks him ' Sir, how erto stad? ['How are you doing?']/ I hope ful wele thou has bene rad [expect; frightened]' (843-44), he replies 'Sertes, thou sais wele thare;/ So abayst was I never are' [before] (845-46). The translation provided for 'abayst' by Mary Flowers Braswell is 'upset', a word that contextually may also translate 'afraid' or even 'ashamed' and seems to signify a state of humility in Ywain that likewise resonates in the confession of fear made by Yvain. Similarly, by signifying a clear outsider status for the knight through their display of anger and sorrow, the people of Landuc ultimately motivate Ywain's in-group status, which can only be brought about through the knight's fear and humility. ${ }^{422}$ It is in this humble state that Ywain is able to

\footnotetext{
${ }^{420}$ Note that the 'grete noyse' made by the retainers, foretold by Lunet as 'a sary cry and a doleful dyn' (788-89; repeated in lines 833-4) is similar to the display of grief by the courtiers' 'hue and cry' in Ívens saga.

${ }^{421}$ Busby, 'Chrétien de Troyes English'd', 603-4; 605.

${ }^{422}$ Lynch has pointed out for the Stanzaic Morte that through the employment of Middle English 'make'-also employed here in 'making sorrow' (706, 815) — 'the text treats these emotions as actions' ('Making Joy/Seeing
} 
win over Aludyne and as the new lord and defender of the Land of the Fountain is able to reinstate order to Landuc.

\section{Mixed Emotions}

So far, this chapter has discussed the presence and function of primary collective emotions in arrival scenes. The Noroison welcome schema projected the primary positive emotion joy, while the Landuc welcome schema underlined the primary negative emotions anger, sadness (grief) and fear. ${ }^{423}$ The marked contrast between both arrival scenes raises the question whether such instances of group emotion are solely dominated by what are often termed 'basic' emotions or whether the communal feeling may also reflect as well as project what emotion theorists call 'complex' emotions. ${ }^{424}$ Basic emotions are singular feelings that are innate and automatic and therefore universal. They are grouped on either a positive or negative basis (joy versus sadness). Complex emotions, conversely, are non-universals that may arise from cultural conditioning and association. They represent an aggregate of two or more basic emotions that may blend or occur sequentially, like the more complicated loverelated emotions described for individual characters in chapter one and two.

Sorrow', 36). Likewise, the retainers in this scene may be said to perform grief and anger, in the sense that they provide the expresssion of grief and anger with the narratological function of furthering the action.

${ }^{423}$ Not all emotion theorists agree on the number of basic emotions or how they are to be classified. Whereas some identify grief as a basic emotion based on its somatic manifestation (see William James, The Principles of Philosophy, 2 vols, New York: Henry Holt and Company, 1890), recent studies tend to think of grief as a compound emotion, variable in its expression and composition (Paul Ekman, 'Basic Emotions', in Handbook of Cognition and Emotion, ed. Tim Dalgleish and Mick J. Power, Chichester: John Wiley and Sons, 1999, 45-60; also see Robert Plutchik's 'wheel of emotions', 'Nature of Emotions', American Scientist 89.4 (2002), 344-50.)

${ }^{424}$ For a discussion of both terms see pp. 9-11, especially footnote 11. Important contributions to the debate are, Ekman, 'Basic Emotions', 45-60; Damasio, The Feeling of what Happens, especially chapter two; Plutchik, 'Nature of Emotions', 344-50. 
Although such occasions are rare in Yvain, a mix of both positive and negative collective emotions is displayed by the retinue of Gauvain's brother-in-law, where Yvain will have to fight the giant Harpin de la Montaingne (see Appendix, Synopsis, episode V). ${ }^{425}$ Although Yvain is on his way to rescue Lunete from being burned at the stake for treason against her lady, he stops at a stronghold to find lodging for the night. Upon his arrival, the narrative focus goes out to a group of knights, ladies, men-at-arms and damsels, who, in accordance with the conventions of hospitality (Yvain, 3811-12) welcome him with joy and great cheer. Yet they at the same time show signs of heavy sorrow:

Des le plus haut jusqu'au menor

li font joie et formant s'an painnent;

a grant joie a l'ostel l'en mainnent.

Et quant grant joie li ont feite,

une dolors qui les desheite

lor refet la joie oblïer;

si recomancent a crier,

et plorent, et si s'esgratinent.

Ensi molt longuemant ne finent

de joie feire et de plorer:

joie por lor oste enorer

font sanz ce, que talent en aient,

car d'une aventure s'esmaient

qu'il atendent a l'andemain.

\footnotetext{
${ }^{425}$ The welcome Yvain receives at his arrival at the castle of Pesme Aventure is the only other example I have found in Yvain that is indicative of a more complex group feeling, that represents neither sadness nor joy.
} 
Mes sire Yvains s'esbaïssoit

De ce que si sovant chanjoient

Que duel et joie demenoient. (3816-34)

[Everyone, from the highest to the lowest,

did their best to make him feel welcome;

amidst great rejoicing they showed him to his lodgings.

Yet after having shown their gladness,

grief overwhelmed them,

causing them forget their joy; they began to cry out,

to weep and to tear at themselves.

So for a long time they continued

in this manner, alternating joy and weeping:

in order to honour their guest

they acted joyfully in spite of themselves,

for they were fearful about an adventure

they were expecting the next day.

My lord Yvain was troubled

to see them changing moods so often

for they showed both grief and joy.]

The rapid change of moods in the community welcoming Yvain — displaying great joy one minute and intense grief the next—signifies that something is amiss. Despite the people's 
insistence upon conveying 'joie' (it occurs up to eight times in the passage above), their sorrow seems to manifest itself bodily beyond their control. As they cry out, weep and tear at themselves (3822-23), feelings of doubt and alarm may be triggered in the audience who is invited to question the community's conflicting behaviour.

In 'blide ende drove', Brandsma examines several passages containing mixed emotions in Middle Dutch Arthurian romance and concludes that 'mixed emotions form an exceptional narrative element that calls for an explanation by the narrator' ${ }^{426}$ Indeed, the curious behaviour of the community also prompts the narrator in Yvain to explain: 'they acted joyfully in spite of themselves/ for they were fearful about an adventure/ they were expecting the next day' (3829-31). Rather than providing the audience with a straightforward answer, Chrétien has the narrator dose the information he gives out. Although he does draw attention to the fact that the community's joy had to be feigned due to their fear, he does not disclose what it is exactly that they are frightened of. By choosing to keep his audience mystified, the ominous feeling projected onto the audience is only further intensified by means of Verrätselung. ${ }^{427}$

When thereupon Yvain asks his host after the cause of their fear, suspense is further drawn out, since his host refuses to burden the knight with the news and Yvain has to press him repeatedly before he finally reveals that they have been terrorised by a giant over the past weeks. Having already killed two of the baron's sons in front of his very eyes, the giant has threatened to kill the other four the coming day should they not hand over their daughter to him in marriage.

\footnotetext{
${ }^{426}$ Brandsma, 'blide ende drove: Mixed Emotions in Middle Dutch Arthurian Romance', 112.

${ }^{427}$ Verrätselung or 'mystification' is a narrative technique described for Chrétien de Troyes by the German scholar Walter Haug ( 'Das Land von welchem niemand wiederkehrt': Mythos, Fiktion und Wahrheit in
} Chrétiens Chevalier de la charrette, in Lanzelet Ulrichs von Zatzikhoven und im Lancelot Prosaroman, Untersuchungen zur deutschen Literaturgeschichte 21, Tubingen: Max Niemeyer Verlag, 1978). 
Even after the knight agrees to come to the community's aid, the alternation of positive and negative emotions — albeit sequentially from this point on —allows for an atmosphere of foreboding to build right up until the moment of the fight (3945-4092). The audience is taken on an 'emotional rollercoaster' as the community goes back and forth between hope and fear. Their relief in finding a defender turns to anxiety as Yvain refuses to give them absolute assurance of his help since he is bound by his promise to Lunete to defend her cause later the next day. When the honourable sister and niece of Gauvain beg at his feet in tears, they all find hope and joy again in his promise that he will stay until prime. When the giant, however, does not arrive in time and Yvain announces his leave everyone's blood 'quaked and boiled with fear' and they all began to weep aloud in distress and anguish (404865). The giant arrives just in the nick of time and the household now assists in arming the knight. The narrative, however, continues to project a feeling of foreboding onto the audience through the mirroring function of the community. Again, the narrative focus is with the courtiers who start to pray frantically as they watch the fight from the castle walls:

Et cil qui sont remés arriere

le comandent au Salveor, car de lui ont molt grant peor que li maufez, li anemis, qui avoit maint prodome ocis veant lor ialz, enmi la place, autretel de lui ne reface.

Si prïent Deu qu'il le desfande de mort, et vif et sain lor rande, et le jaiaint li don't ocirre; 
si come chascuns le desirre

an prie Deu molt dolcemant. (4173-83, my emphasis)

Those who remained behind

commended his soul to the Saviour,

for they were very afraid

that the wicked devil, their enemy,

who had slain many a good man

in the square before their eyes,

would do the same to him.

They prayed to God to protect him from death,

to return him to them alive,

and to grant him to slay the giant.

Each of them prayed this silent prayer

to God in his own manner.

Although the focalisation only briefly switches towards the castle inhabitants, it is enough to create the illusion of a poor outcome for Yvain. After all, it has not boded well for those defenders who came before him. The desperate nature of the courtiers' prayers underlines the hopelessness of the situation and leaves the reader/listener to expect the worst.

When Yvain, however, finally manages to kill his brutal adversary, the joy and relief experienced is all the greater. The communal joy is so strong, that the spectators turn into a frenzied fanbase as the giant goes down with a thundering shake:

Ce cop vuelent molt tuit veoir 
cil qui estoient as creniax.

Lors i parut li plus isniax

Que tuit corent a la cuiriee,

si com li chiens qui a chaciee

la beste, tant quë il l'a prise;

ensi coroient sanz feintise

tuit et totes par enhatine

la ou cil gist gole sovine.

Li sires meïmes i cort

et tote la gent de sa cort;

cort i la fille, cort la mere,

or ont joie li .iiii. frère

qui molt avoient mal sofert. (4250-63, my emphasis)

[All those on the castle walls were eager to behold this blow.

Then it was made clear who was swiftest

among them,

for they all ran to grab the spoils of the hunt

just like the hound that pursues

the game until he has caught it;

In this same manner all the men and women ran

unabashedly and excitedly

to where the giant lay upon his back.

The lord himself ran there,

and all the members of his court; 
so did his daughter, so did his wife.

Now the four brothers, who had suffered

many hardships, rejoiced.]

Emotions run high in this scene. As the focalisation switches from the group to those individuals having been most affected by the giant, their emotive behaviour starts having an infectious impact. All the members of the court, men and women alike, as well as the lord and lady and their children, form one emotional community as they all share in Yvain's victory. This invites a heightened emotive experience in the audience as well, as through the mirroring experience, they momentarily share in the communal feeling thus created.

The arrival schema is also at play in Ívens saga. The knight is likewise welcomed with joy by the community:

Hann reið inn í höllina ok kómu par riddarar ok heyskar meyjar ok fögnuðu honum með mikilli blíðu. En er peer gengu brott, var par allt með hrygð ok angri. petta pótti herra Íven undarligt ok spurði húsbónda hví p at sætti. (76, my emphasis)

[He rode into the hall and knights and courtly maidens came toward him and welcomed him with great amiability. But when they left there was nothing but grief and sorrow. Sir Íven thought this strange and asked his host why this was so.]

Different from the French source, the communal feeling described in translation is dependent upon social status. Instead of 'everyone, from the highest to the lowest' (Yvain, 3816), only 'knights and courtly maidens' make up the welcome committee. This slight amelioration in courtliness of the community may also explain why this group of characters does not show 
their grief in front of the knight in the Norse translation. Unlike the amalgamation of joy and sorrow expressed in Yvain at the knight's arrival, there is a clear separation between the two conflicting emotional states in Ívens saga as it is added that the sudden change to grief takes place only when the group leaves the hall. Neither Íven, nor the extradiegetic audience is witness to the somatic manifestation of sadness that these characters display in Chrétien's text: they do not cry out, weep or tear at themselves.

What is more, those indicators present in Yvain to suggest that their joy was acted and that their sorrow was beyond their control have not been rendered. Although Íven does voice his wonderment over the sudden change in emotional state, there is nothing to suggest that he is troubled by it. The Old Norse-Icelandic rendition therefore does not seem to aim at projecting feelings of alarm onto the audience. Rather than mystified, the courtiers' behaviour is rationalised in translation.

The same can be noted for the courtiers' second focalisation on the castle walls, which has been reduced to one line in the Old Norse: 'En allt pat fólk er $i$ kastalanum var bað fyrir riddaranum, at guð skyldi geyma hans fyrir pessu trölli.'(78, my emphasis) (And all the people who were in the castle prayed for the knight, asking God to protect him against this troll). Although the community's performance has been adopted, its purpose as mirror characters projecting feelings of alarm unto the audience is less explicit. The community's presence in the scene does not not neccesarily serve an emotive end. Unlike their Old French counterparts, they do not express feelings of 'fear' (grant peor, 4175) regarding Yvain's fate. What is more, the motivation behind the courtiers' prayers, as told by Chrétien — the fact that they have seen many an adversary being slayed by Harpin in the past weeks - is not given in Ívens saga.

Rather than a joint effort, the knight's victory over the giant is presented as an individual one in the Norse translation. The sense of 'us' that is created by Chrétien through 
the collective arming of the knight, the collective fear expressed over the knight's fate and the continuous prayers by 'each and every one of them' are all toned down by the Old Norse translator. Firstly, the community's role in preparing the knight for battle is omitted, an alteration to Chrétien's text that I have found to be consistent throughout Ívens saga and Erex saga, and also occasionally in Parceval saga. In all three translated romances such arming scenes are either completely omitted, or, more specifically, their communal function is removed by presenting an image of the knight arming himself. ${ }^{428}$ What is more, as has already been stated, the courtiers do not express any fear over the battle's outcome. Whereas the community's prayers are followed in the French text by the giant who comes at Yvain with fierce bravado ('Et cil par son fier hardemant/ vint vers lui, si le menaca', 4184-85), in the Norse text Íven boldy rides out of the castle against the giant instead ('ríðr út af kastalanum djarfliga í móti jötninum', 78).

The Norse rendition of the final communal performance on the castle walls is much less emotive than its French source. Since the description does not switch in focalisation from the collective emotion displayed by all the men and women to the expression of individual joy, first by the lord, followed by his daughter, his wife and the four surviving brothers, there is no sense of a heightened emotive impact for those witnesses inside or outside of the narrative:

Steyptiz pá jötunninn til jarðar ok varð pá svá mikill gnýr at öll jörðin skalf. Petta sá hertuginn i kastalanum ok allt hans folk. Hlupu peir pegar út af kastalanum í móti Íven

\footnotetext{
${ }^{428}$ Compare for instance Yvain 3135-45 with Ívens saga 70; Yvain 5574-77 with Ívens saga 88; Erec et Enide 707-10 with Erex saga 228; Erec et Enide 5636-46 with Erex saga 254; Perceval 2641-52 with Parcevals saga 140; 4234-41 with Parcevals saga 162. More than the other two translations, Parcevals saga at times invests in such arming scenes, see the arming of the knight at Gormanz castle at 128.
} 
ok buðu honum kastalann ok sjálfa sik í vald ok báðu hann með sér vera. (78, my emphasis)

[The giant then pitched to the ground and there was such a great crash that the entire earth shook. The duke in the castle saw this as did all his people. They rushed at once out of the castle to meet Íven and offered to place the castle and themselves into his power and asked him to stay with them.]

Instead of elation, the Old Norse translation conveys an image of subservience. Chrétien's euphoric crowd who takes part in the spoils by celebrating their victory at the site of the corpse, is replaced for an image of loyal liegemen, who rush out to offer their services in honour of the knight.

The Middle English narrative for the most part follows its Old French source, both in length and the portrayal of mixed emotions. When Ywain reaches the stronghold he is greeted by a community likewise tormented by feelings of both joy and sadness. The lord of the castle welcomes him first, greeting him in the assembled company of knights, squires, fair ladies and maidens:

Bot right with that the lord he met,

And ful gladly he him gret,

With knyghtes and swiers grete plenté,

And fair ladies and maydens fre;

Ful mekyl joy of him thai made,

Bot sorrow in thaire hertes thai hade.

Unto a chameber was he led 
And unharmed and sethin cled

In clothes that war gay and dere.

Bot ofttymes changed thaire chere;

Sum tyme, he saw, thai weped all.

Als ai wald to water fall;

Thai made slike murnyng and slik mane

That gretter saw he nane;

Thai feynyd tham oft for hys sake

Fayre semblant forto make.

Ful grete wonder sir Ywayn hade

For thai swilk joy and sorrow made.

'Sir', he said, 'if yowre wil ware.

I wald wyt why ye make slike kare'.

'This joy,' he said, 'that we mak now,

Sir, es al for we have yow; [unarmed; afterwards dressed]

[costly]

[manner]

[ever would; turn]

[such] [if it be your will]

[mourning]

[is all because you're here]

And, sir, also we mak this sorrow

For dedys that sal be done to-morrow. (2225-48, my emphasis)

Not only is Ywain met by the lord himself-who in Yvain and Ívens saga does not make his appearance until the knight informs after the people's conflicting emotions - but the hospitality and honour Ywain receives is also played-up by the Middle English translator as the community removes his armour and clads him in expensive clothing (2232-33). It is, moreover, stressed that their joy was 'feigned' for the knight's sake, a semblance of composure that is presented in Ywain and Gawain as an act of decorum, as another sign of their hospitality, rather than solely the mystification or intensification of ominous foreboding. 
Like Chrétien, the English poet has invested in underlining the atmosphere of foreboding pervading in the castle. Immediately after Ywain agrees to fight the giant, the host and his retinue pray that God will aid the knight the next day (2309-12). When Harpin arrives at the castle, these prayers are reiterated first by the ladies of the castle, who assist in arming the knight:

Sone was he armed, sir Ywayn;

Tharfore the ladies war ful fayn. [joyous]

Thai helped to lace him in his wede, [armor]

And sone he lepe up on his stede.

Thai prai to God that grace him grant

Forto sla that foul geant. $(2417-22)$

Whereas Chrétien is referring to the entire community rooting for the knight on the castle walls, the English poet next zooms in on the emotive behaviour of the male courtiers. Instead of 'each praying their silent prayer in their own manner' (Yvain, 4183-4), the men fall to their knees, a gesture congruent with their performance of the previous night:

Ful mani sari murnand man

Left he in the kastel than,

That on thaire knees to God of might

Praied ful hertly for the knight. (2425-28)

After the battle, the focus is again on the male courtiers as specific witnesses to Ywain's victory. Rather than of 'all the men and women' and 'all the members of his court' (Yvain, 
$4257,4260)$ first 'many a joyful man' $(Y G, 2486,2490)$ comes out to celebrate the knight, followed by the lady and her daughter:

Than was nane other tale to tell,

Bot fast unto the erth he fell,

Als it had bene a hevy tre.

Than myght men in the kastel se

Ful mekil mirth on ilka side.

The gates kest thai opyn wyde;

The lord unto Syr Ywaine ran,

Him foloud many a joyful man;

Also the lady ran ful fast,

And hir doghter was noght the last.

I may noght tel the joy thai has;

And the foure brether war ful glad,

For thai war out of bales broght. (2483-95, my emphasis)

These gender specifications signal a mediation of the narrative orientation of Ywain and Gawain that may reflect the 'predominantly masculine interest of the poet and his audience' that has been noted by Busby for the Middle English poem. ${ }^{429}$ Busby assigns a general switch of attention from women to men and believes these alterations to conform to the predilections of a male-oriented, and possibly, less aristocratic audience. ${ }^{430}$ Aside from this gender specification, the mirroring function of the group focalised corresponds to that in Yvain. The

\footnotetext{
${ }^{429}$ Busby, 'Chrétien de Troyes English'd', 605.

${ }^{430}$ Ibid. 603-4.
} 
emotive impact of the scene, brought about as the focalisation switches from the excitement displayed by the group to individual joy, stays intact.

\section{Conclusion}

The communal feeling is typically exploited by Chrétien in scenes of arrival in which the (un)welcome schema is at play. In such scenes, the community, represented by groups of marginal characters, such as 'everyone', 'all the men and women' or 'the courtiers', is repeatedly foregrounded in its unified appraisal of the knight. The community plays an important part in the construction of the knight's identity in Yvain's emotive script. Just as much as it has the potential to construct an ideal image of the knight, it has the potential to question his actions and reputation. These communal performances therefore not just underline the sequential adventure structure of Yvain, but at the same time motivate it. Ingroup and outgroup-sentiments motivate Yvain's actions and function as an incitement to the storyline. What is more, they allow Chrétien to manage his audience's expectations and to bring about its empathetic involvement. The community, which often takes on a witnessing and/or evaluating position, may fulfil a mirroring function as it invites the extradiegetic audience to share in their appraisal of the knight. The communal feeling may thus be extended.

In both Ívens saga and Ywain and Gawain the structural function of such arrival scenes seems to have been recognised and adopted. From his first arrival, the community either acts in hospitality of the knight or in hostility. The extending effect onto the audience of such groups of characters through their repeated focalisation is, however, not always (fully) exploited. Three correspondences can be assigned in the way images of collective emotion are redrawn in both the Old Norse-Icelandic and Middle English renditions. Firstly, the length 
and number of communal performances are generally reduced, presumably due to the overall condensation of the French source. Secondly, the appraising function of the community is either expressed following a more prominent/familiar character in the story, rather than as a group on its own, or is completely redirected towards these main characters. These alterations with regard to the characters who witness and evaluate the knight's actions are, thirdly, often concerned with their hierarchy and/or gender.

Despite the overall similarities when it comes to the engagement of the Old Norse and Middle English translators with Chrétien's images of collective emotion and the ways these group performances have been mediated into more accessible renditions, no correspondences can be assigned between the two in the individual passages examined here. There is thus no evidence for the thesis that these two translations have had an impact on each other. Whereas the Norse translator greatly reduces the outgroup-sentiments expressed by the people of Landuc at the expense of anticipation management and suspense, he/she nevertheless invests in direct speech, deployment of metaphor and female mirror characters when it comes to the positive appraisal of the knight by the castle inhabitants of Noroison. These translational choices may be part of a more general upgrading of the community in Ívens saga. Rather than 'everyone, high and low' who welcome Yvain in the town of Gauvain's family, Íven is greeted by 'knights and courtly ladies', who, unlike the community in Yvain and Ywain and Gawain, do not show their grief in front of the knight. The English translator, conversely, plays up the hostile nature and anti-sentiments of Esclados' subjects, among other things by presenting them as vengeful men, in favour of anticipation management and suspense. Similarly, the communal feeling in the Harpin-episode is male-oriented, as those foregrounded during the fight are men.

Although in both translations group emotion is specified to be expressed in imitation of a main character rather than as a community on its own, this is never at the same moment 
in the narrative. In Ívens saga, both the joy-making of the people of Noroison and the grief expressed by Laudine's courtiers are preceded by a narrative focus on their lady's feelings. In Ywain and Gawain, the mixed feelings expressed by the community terrorised by Harpin the giant are preceded by their lord's. In both renditions of Yvain's fight against earl Aliers the focus is set on female characters in praise of the knight. In Ívens saga, however, the narrative focus zooms in on a group of maidens, whereas in Ywain and Gawain the Lady of Noroison and her maiden are the sole focalisers in the scene and the focal point remains with them until the earl is captured.

It should be noted that those images of collective emotion that have been highlighted in this chapter all revolve around sight. It is through the eyes of the community on the castle walls (or, in the case of Ívens saga and Ywain and Gawain, at times through the eyes of more familiar characters) that the extradiegetic audience observes and evaluates the knight and his actions during his fight against both Count Aliers and Harpin de la Montaingne. It is in particular their elevated position that allows for such an extended view. When Yvain is imprisoned in the castle of Landuc, the narrative focus switches from the trapped knight who is comforted by Lunete to the mourning courtiers awaiting on a higher level upstairs. Later in the scene, Yvain is shielded from their sight, although not from their judgement, by an invisibility ring. The courtiers' inability to see the knight, addressed in the text as a blindness, may well also be figurative as they are at that point still blind to who Yvain is and do not yet recognise him as their new lord. After all, Lunete who is able to see the knight, also figuratively sees Yvain for who he is due to her past experience with him at Arthur's court.

Lastly, the collective appraissals of the knight discussed in this chapter predominantly involve primary emotions, such as joy and anger, but are not solely dominated by basic emotions. An examination of the welcome schema in the Harpin-episode has revealed the representation of complex group emotions. Whereas Chrétien blends positive and negative 
emotions (joy, sadness and anger) which allow for a certain level of mystification in the scene, the Norse translator rationalises the scene and clearly separates the emotional states of joy and sadness in the courtiers by presenting them sequentially. What is more, the emotion of fear is removed from the scene.

This chapter, however, also demonstrates that in addition to the question 'What do these groups of characters feel?', there is value in asking 'What do these collective emotions do?' for the storyline and the construction of the image of the knight-protagonist. ${ }^{431}$ In answering this question, this chapter shows that denominators such as 'positive' and 'negative' are dependant on textual as well as, it seems, on cultural circumstance. There is positive value to both Yvain's and Ywain's fear, as this emotional state aids in balancing out the knight's earlier mistake of killing Laudine's husband and thereby assists in restoring his reputation, both in the text and in the eyes of the audience. The explicit negation of fear on the knight's part in Ívens saga, conversely, suggests a negative assessment of that same emotion. In the same manner, anger is ultimately of positive value in the Landuc scene, in the sense that it has a remedial function and serves as a necessary evil to the reinstatement of order and joy.

\footnotetext{
${ }^{431}$ In doing so, I am following W. Gerrod Parrott, who notes: ' $[\mathrm{t}]$ he most central question about an emotion is no longer "How does it feel?", but rather "What does it do?", thereby referring to recent insights from psychological studies that point towards the positive value of negative emotions ('Feeling, Function, and the Place of Negative Emotions in a Happy Life, in The Positive Side of Negative Emotions, ed. W. Gerrod Parrott, New York: Guildford Press, 2014, 273-97).
} 


\section{CONCLUSION}

In the process of highlighting the mediating engagement with the representation of emotion in Yvain by different textual traditions, this study has brought to the fore the disjunction between modern and medieval conceptions of translation. The question of whether we should view the different Yvain-versions as translations, adaptations or reworkings addressed in the introduction to this study has proved to be a problematic one. Although in a comparative study such as this, one cannot avoid the use of these modern denominators in describing the different versions without losing track of their interdependency, the way these medieval renditions convey the emotive content of Chrétien's text ultimately cannot be captured in any such singular terms. As it turns out, each individual literary work discussed here contains unique dimensions of translation, which may deviate from episode to episode, depending on the level of foreignisation and domestication of its source. While some passages reveal a process of close translation, others show clear signs of adaptation and, occasionally, even rewriting. This study therefore shows that we should not rethink the terminology, but the question of source fidelity itself when it comes to medieval translation practices. Instead of focusing on the product of adaptation by debating the degree of proximity to its 'original', we should approach the origination of the different Yvain renditions in light of their adaptation process. This study has foregrounded this adaptation process as an act of mediation, utilising the concept of emotive script to illustrate this.

Studying these texts on the basis of their emotive scripts allows us to reflect upon these unique dimensions of translation, as it permits us to move beyond describing medieval literary translations solely in the contradictory terms of their correspondences and deviations in relation to their source - in which deviation designates the contestation and correspondence 
denotes the adoption of its emotive representation within its new context. Rather than explaining deviations exclusively as contestations of their source, that, according to Copeland, 'seek to erase the cultural gap from which literary translation emerges by displacing the source and substituting itself', the different chapters of this study have shown that such transformation seeks to close this cultural gap and have revealed an act of mediation in rendering the strange familiar. ${ }^{432}$ In their alignment of emotive scripts, the different renditions of Yvain fall somewhere between the foreign literary standards of their source text and those literary standards more native to their audiences. In this mediating position, they contain traces of the emotive codes and conventions of both the translated and translating tradition. That is why the different translations of Yvain can be said to reveal (on varying levels) a certain hybridisation when it comes to their emotive representation. ${ }^{433}$ By comparing emotive scripts, this study has attempted to reconstruct this intercultural space, in which the translator has been foregrounded as a 'fixer' of any incompatibilities in emotive representation, whose mediating engagement with the foreign linguistic, cultural and literary codes in Yvain's emotive script has proved to be more attentive than has previously been assumed. Each chapter has brought to light different signs of engagement with Yvain's emotive script by the respective textual traditions.

Chapter one has illustrated this type of mediation for the Old Norse-Icelandic rendition of Yvain's heart conceptions and its love-related imagery. In its transposition of French courtly love lyrical conventions, Ívens saga reveals evidence for the Norse translator's engagement with these twelfth century representations of the heart and its idiomatic

\footnotetext{
${ }^{432}$ Copeland, Rhetoric, Hermeneutics, and Translation, 30, as discussed on p. 66 of this study.

433 This type of hybridity - a mixture of literary conventions and stylistic traits within one literary work-is for example explored in A Critical Companion to Old Norse Literary Genre, ed. Massimiliano Bampi, Carolyne Larrington and Sif Rikhardsdottir (Woodbridge: Boydell \& Brewer, 2020). For a discussion of the genre of ‘romance’ specifically see Jürg Glauser’s chapter ‘Romance_-A Case Study’ at 299-312.
} 
phraseology, tropes and motifs. A close reading of their respective emotive scripts has revealed the translator's engagement with the semantic profile of the personhood concept cuer as found in Chrétien's love casuistry. Rather than the stirrings of the cuer (heart), the sensations ascribed to characters in Ívens saga are predominantly presented as movements of the hugr (mind). These sensations may still be understood to be housed in the hjarta (heart), but are of a different origin and faculty. Throughout Ívens saga there is a focus on the cognitive processes involved in love. The chapter, moreover, has revealed signs of an unfamiliarity with or, possibly even, a rejection of Chrétien's perception model in the transcoding of the story. Unlike French cuer, Old Norse hugr is not characterised by its attendance of the senses, that are ascribed an important function in bringing about sensations in the heart. This literary image of interiority, in which the senses are the doorways or channels through which external impressions enter the heart, comes to expression in Yvain through various tropes, such as memoria as the storehouse of affective rumination, the hearteyes motif and the itinerant heart-motif. The chapter has shown a systematic transformation and/or omission for the latter two motifs in Ívens saga.

The care and consistency with which many of these images have been reformulated suggest that they may have been conceived of as obstacles in the merging of emotive scripts and their pre-established conventions for the representation of love. Cuer, as we find it in Chrétien's work, seems to have been an unfamiliar literary concept to Nordic audiences. Its metaphorical representation and its assigned faculties and functions had to be redrawn into a signifying model that was meaningful within its new literary context. Despite the reformulations and omissions assigned, much of Yvain's imagery is also reproduced. Although the prissonier d'amour metaphor, Calogrenant's cuer et oreilles topos and the heart-eyes motif have been transformed to underline the cognitive processes involved in such 
imagery, they nonetheless retain the general meaning of these metaphors and adopt some of its poetic language.

When we take into consideration the fact that the French romance and Norse saga tradition followed vastly different standards for the representation of the heart and for love in general, the mediations assigned for Ívens saga in reproducing French matters of the heart may ultimately have led to an enrichment of those conventions in Old-Norse Icelandic literature, as well as its use of (poetic) language. ${ }^{434}$ Over time, these newly formed standards may have caused a shift in the horizon of feeling of Nordic audiences, whether of those living in Norway in the thirteenth century or in Iceland in the fourteenth century and beyond, or possibly of both reading communities. Although such mediations are generally ascribed to the Norwegian translator, this chapter, as well as chapter three, has had to take into consideration the considerable temporal gap between the presumed composition of Ívens saga and the manuscript copies that preserve it, when it comes to drawing culturally-based conclusions regarding the possible motivations behind the modifications addressed. Regardless of whether these alterations belong to the Norse translator or to a later Icelandic redactor, they nonetheless illustrate the active engagement of Nordic translators, scribes and their audiences with French romance material.

Chapter two has likewise illustrated the engagement with the underlying generic codes and ideology of courtly love in Yvain's emotive script, this time in the German textual tradition. Where chapter one focuses on the inner life of characters and the experience of 'having an emotion', chapter two examines 'the doing of emotion' that is communicated through the expressive behaviour of those same characters. It draws attention to the function of gestures in the narrative staging of emotion and their significance for the medieval interpreter. While the B-author of Iwein adopts the symbolic function of the knee-fall in

\footnotetext{
${ }^{434}$ Note that this gap is considerably smaller for the continental traditions discussed in this study.
} 
his/her engagement with Yvain's emotive script for the resolution of the love dilemma, its context is renegotiated as Laudîne falls to her knees as well. This places her on the same level with her husband, as they are now equal, both in their show of contrition and affection. Yvain's emotive script for courtly love is further expanded upon through the addition of female speech and male non-speech. Îwein's silence may just as much be read as a narrative sign that communicates information of an emotional nature to the reader/listener. The knight's silence and Laudîne's subsequent reciprocation of her husband's knee-fall in Iwein's Bending profoundly alter the love ideal that is encoded in Yvain. Individual offence becomes mutual responsibility through the repositioning of the power relations of the lovers, thereby transforming courtly love into Ehe-Minne.

This German rendition of the story perfectly showcases the misleading nature of the terms source and translation, discussed in the introduction to this study. Like Ívens saga, Iwein reveals multiple stages of adaptation. We cannot with absolute certainty reconstruct the text to originate its textual tradition. The mediations addressed for the B-redaction when it comes to reconciling the lovers likewise demonstrate the active engagement of authors (or possibly one and the same author in this case) with the story of Yvain in adjusting its emotive codes to meet the literary preferences of their audiences. The existence of two different endings for Iwein raises questions not only of a duality in authorship, but also in 'audienceship'. Since the oldest manuscript copies to preserve the A- and B-redactions stem from the same period, either both versions may have circulated around the same timesuggesting that literary preferences may have differed between reading communities, whether divided by region or gender — or both versions may have come about in rapid succession of one another-attesting to the fact that the horizon of feeling of an audience is in constant flux. In the first case it seems plausible that the altered reconciliation of the lovers was indeed aimed, as has often been suggested, at female readership. In the latter case, in particular, it 
seems plausible that the altered reconciliation scene was brought on by the popularity of Hartmann's Erec, a narrative that, as chapter two has demonstrated, reveals the same redirected love ideal as well as a similar restaging of the heroine's bodily actions and speech. While such deliberations remain beyond the scope of this study, they illustrate the influence of the changing literary tastes and/or of the socio-cultural concerns of their presumed audiences on the representation of emotion within these texts.

Whereas chapter two illustrates the renegotiation of Yvain's emotive script through the amplification of performative action and speech, chapter three, conversely, foregrounds this act of mediation through the abridgement of this script for the staging of group emotion. The chapter explores the literary construction of the communal feeling in Yvain and compares its various narratological functions for Ywain and Gawain, as well as for Ívens saga. Both the English and Norse translator seem to have recognised and adopted the function of these intext communities within their French source as the enactors and enforcers of social structure within the Arthurian world, who motivate both the knight's actions and the storyline. The community's emotive appraisals, so elaborately depicted in Yvain, are, however, greatly condensed by both translators. The length and number of such group performances and their level of emotive expressivity is often reduced, thus at times altering their extending emotive function to the extra-diegetic audience whether through anticipation management, direct speech and/or the deployment of mirror characters.

Additionally, an examination of the way in which the communal feeling is rendered in these texts has revealed that both translators at times renegotiate the identity of such communities or of sub-groups within them. Firstly, the modifications that have been assigned are of a hierarchical order. In both Ywain and Gawain and Ívens saga, collective emotion is often expressed following a main character rather than as a community on its own. Both renditions at times reflect a concern for status. In both the Landuc episode as well as the 
Harpin episode in Ívens saga, the community in appraisal of the knight is ascribed a higher social standing and anti-sentiments are considerably toned down. The English translator tends to ascribe such group appraisals to more prominent/familiar characters throughout Ywain and Gawain.

Secondly, the alterations in the Middle English and Norse-Icelandic renditions concern gendered behavioural representation. Whereas in Yvain, the communal feeling is shared by the unified subjects cil et celes, chascun et chascun, and tuit et totes that include both genders, both translations seem to distinguish between normative behaviour for male and female characters. In both versions of Yvain's fight against Count Aliers, words of praise and admiration are specifically reserved for female characters, presumably to re-construct the knight's heroic reputation and masculine identity after his public denunciation by his lady earlier in the story. The Middle English Ywain and Gawain, in particular, reflects an emotive script that is predominantly male-oriented. Both the Landuc and the Harpin episodes are rescripted so that the emotive reactions of the male community are foregrounded. The mourning courtiers in the castle of Landuc are specifically identified as male and their relentless baying for blood reflects the normative behaviour of vengeful retainers rather than that of a community enflamed by their collective grief as presented in Yvain. In Ywain's fight against Harpin, the focus is likewise on the male spectators as the community prays for the knight and ultimately shares both in his spoils and his joy. The women take on a more subordinate role as they assist in arming the knight, a task that in Yvain is ascribed to the entire community.

Together, these case studies demonstrate 'the merit' that is to be found in 'chartering the narrative articulation of emotion across languages, cultures, genres and centuries' through a close comparative reading of the cross-cultural translations of one and the same Arthurian 
story, addressed in the introduction to this study. ${ }^{435}$ Comparing emotive scripts has proved a valuable approach in mapping the narrative staging and re-staging of emotion for the different versions of the story of the Knight with the Lion. Rather than studying these literary works individually for their emotive content and narrative strategies, comparing emotive scripts for the different Yvain-versions has revealed unique concerns for the representation of emotion that would otherwise not have surfaced. In capturing the linguistic, cultural, generic and historical incompatibilities for emotive representation between various literary traditions, these translations therefore help to understand each other. In their intermediary position they bring to the fore the quintessentials of the literary codes and conventions of both the original and the receiving cultures.

That is why tracing the transformations in these texts' respective emotive scripts helps us interpret the emotive representation of the individual narratives beyond the level of understanding of what our modern literary framework permits. Since we do not share the same 'literary emotional memory' with their respective medieval audiences, we can no longer fully access the emotive codes underlying these texts. ${ }^{436}$ Tracing the renegotiation of Yvain's emotive representations by the different translators offers us further insight into these codes, as it is through their transformation that these medieval emotive representations become more intelligible to us.

It is through the specific engagement with Yvain's heart-imagery assigned for Ívens saga in chapter one that the particularities of these French matters of the heart come to the fore. The translator's meticulous transformation of Yvain's heart-and sensory models in such representations discloses that these metaphors are not just ornamental, but carry cultural meaning. Likewise, tracing the transformation of the love ideal in Iwein's emotive script in

\footnotetext{
${ }^{435}$ Lynch, 'Positive Emotions', 57.

${ }^{436}$ On 'literary emotional memory', see pp. $13-17$ of this study.
} 
chapter two has given us better insight into those emotive representations that were meaningful for medieval audiences, which included narrative signs, the weight of which the modern reader would not necessarily recognise. Similarly, the engagement with collective emotion in both Ywain and Gawain and Ívens saga discussed in chapter three calls attention to the importance of social structure within these narratives. The modifications made by both translators to the social status and gender of those communities or subgroups in appraisal of the knight specifically illuminate the importance ascribed to (gender) normative behaviour in the English and Old Norse-Icelandic renditions of such emotive representations. These reformulations simultaneously highlight the fact that their French source does not make such distinctions and aims at portraying the entire community, from the highest to the lowest, man and woman alike.

When we accept the premise that these narratives assume meaning through the empathetic engagement of the communities for which they were translated, the transformations assigned for their respective emotive scripts elucidate the horizons of feeling of those newly targeted audiences. At the same time, the analysis of the emotive codes mediated illuminates those literary preferences for Chrétien's implied audience. The many examples presented in each case study that are demonstrative of the same mediation within one and the same emotive script support the notion that those alterations are receptionoriented rather than dictated by the translator's personal inclinations. Uncovering the exact literary and underlying socio-cultural conventions that motivated the alterations to Yvain's emotive script in the different renditions of the story invites further comparative analysis. A more comprehensive investigation of the level of adaptation of the emotional codes in Chrétien's romances, including those translations that exist for Erec et Enide and Perceval for the same textual traditions, may further illuminate the factors behind the mediations outlined in this study and may, ultimately, deepen our understanding of these texts and their audiences. 


\section{BIBLIOGRAPHY}

\section{Primary Works}

Augustine, De Doctrina Christiana, Book 2, trans. Roger Green. Oxford: Clarendon Press, 1995.

Chrétien de Troyes, Arthurian Romances, trans. William W. Kibler. New York: Penguin Books, 1991.

__ Cligès: Auf der Grundlage des Textes von Wendelin Foerster, ed. and trans. Ingrid Kasten. Berlin/New York: De Gruyter, 2006.

— Erec et Enide, ed. and trans. Jean-Marie Fritz, Livre de Poche 'Lettres Gothiques'. Paris: Librairie Générale Française, 1992.

— Erec et Enide, trans. Ruth Harwood Cline. Athens, GA/London: University of Georgia Press, 2000.

—_, Kristian von Troyes: Yvain (Der Löwenritter), ed. Wendelin Foerster. Halle: Verlag von Max Niemeyer, 1902.

$\longrightarrow$ Le chevalier au lion (Yvain), ed. Mario Roques. Paris: Classiques Français du Moyen Age, 1960.

$\longrightarrow$ - Le roman de Perceval ou le conte du Graal, ed. Keith Busby. Tübingen: Max Niemeyer Verlag, 1993.

- The Knight with the Lion, or Yvain, ed. and trans. William W. Kibler. Garland Library of Medieval Literature 48A. New York/London: Garland Publishing, 1985.

Edda: Die Lieder des Codex Regius nebst verwandten Denkmälern, ed. Gustav Neckel, vol. 1: Text. Heidelberg: Carl Winter, 1962.

Elis saga ok Rósamundu, ed. Eugen Kölbing. Heilbronn: Verlag von Gebr. Henninger, 1881. 
Erex saga, ed. and trans. Marianne E. Kalinke, in Norse Romance, ed. Marianne E. Kalinke, vol. 2: The Knights of the Round Table. Arthurian Archives 4. Cambridge, UK: D.S. Brewer, 1999, 217-66.

Gottfried von Straßburg, Tristan, ed. Rüdiger Krohn. Stuttgart: Philipp Reclam, 1980.

— , Tristan, with the Surviving Fragments of 'Tristan' of Thomas, trans. A.T. Hatto. Harmondsworth, England: Penguin, 1960.

Guiamar, in Strengleikar: An Old Norse Translation of Twenty-one Old French Lais. Edited from the Manuscript Uppsala De la Gardie 4-7 - AM 666 b, 4º ed. Robert Cook and Mattias Tveitane. Oslo: Norsk Historisk Kjeldeskrift-institutt, 1979, 11-41.

Gvímars saga, ed. Marianne E. Kalinke, Opuscula 7, Bibliotheca Arnamagnæna, 34. Copenhagen: Reitzel, 1979, 106-39.

Hartmann von Aue, Erec, ed. Manfred Günter Scholz, trans. Suzanne Held. Bibliothek des Mittelalters 5. Frankfurt am Main: Deutscher Klassiker Verlag, 2004.

— Erec, German Romance, ed. and trans. Cyril Edwards, vol. 5. Arthurian Archives 19. Cambridge, UK: D.S. Brewer, 2014.

$\longrightarrow$, Hartmann von Aue: Iwein, ed. and trans. Patrick M. McConeghy. Garland Library of Medieval Literature 19A. New York/London: Garland Publishing, 1984.

—_ Iwein: Der Riter mit dem Lewen, getihtet von den Hern Hartman Dienstman ze Ouwe, ed. by George Friedrich Benecke and Karl Lachmann. Berlin: G. Reimer, 1827.

—_ Iwein: Der Ritter mit dem Löwen, ed. Emil Henrici. Germanistische Handbibliothek 8. Halle an der Saale: Verlag des Buchhandlung des Waisenhauses, 1891.

- Iwein: Eine Erzählung von Hartmann von Aue, 2 vols, ed. Ludwig Wolff based on the text by George Friedrich Benecke and Karl Lachmann. $7^{\text {th }}$ edn., Berlin: De Gruyter, 1968. 
—, Iwein, German Romance, ed. and trans. Cyril Edwards, vol. 3. Arthurian Archives 16. Cambridge, UK: D.S. Brewer, 2007.

Hoerra Ivan, ed. and trans. Henrik Williams and Karin Palmgren, in Norse Romance, ed.

Marianne E. Kalinke, vol. 3: Hoerra Ivan. Arthurian Archives 5. Cambridge, UK: D.S. Brewer, 1999, 10-299.

Herr Ivan: Kritisk upplaga, ed. Erik Noreen. Uppsala: Almqvist \&Wiksell, 1931.

Isidore of Seville, The Etymologies of Isidore of Seville, ed. and trans. Stephen A. Barney.

Cambridge, UK: Cambridge University Press, 2006.

Ívens saga, ed. and trans. Marianne E. Kalinke, in Norse Romance, ed. Marianne E. Kalinke, vol. 2: The Knights of the Round Table. Arthurian Archives 4. Cambridge, UK: D.S. Brewer, 1999, 33-102.

Jean Renart, L'escoufle: Roman d'aventure, ed. Alexandre Micha. Paris: Honoré Champion, 1992.

Marie de France, Les lais de Marie de France, ed. Jean Rychner. Paris: Champion, 1966.

— Penguin Books, 1999.

Parcevals saga, ed. Kirsten Wolf and trans. Helen Maclean, in Norse Romance, ed. Marianne E. Kalinke, vol. 2: The Knights of the Round Table. Arthurian Archives V. Cambridge, UK: D.S. Brewer, 1999, 103-216.

Sir Perceval of Galles and Ywain and Gawain, ed. Mary Flowers Braswell. TEAMS Middle English Text Series. Kalamazoo: The Medieval Institute Publications, 1995.

Snorri Sturluson, Edda: Skáldskaparmál, ed. Anthony Faulkes. London: Viking Society for Northern Research, 1998.

—, Snorri Sturluson: Edda, trans. Anthony Faulkes. London: Dent, 1987.

The Poetic Edda, trans. Carolyne Larrington. Oxford: Oxford University Press, 1996. 
Tristrams saga ok Ísöndar, ed. and trans. Peter Jørgensen, in Norse Romance, ed. Marianne E. Kalinke, vol. 1: The Tristan Legend. Arthurian Archives 3. Cambridge: D.S. Brewer, $1999,23-226$.

Ywain and Gawain, ed. Albert B. Friedman and Norman T. Harrington. Early English Text Society, Original Series 254. London/New York/Toronto: Oxford University Press 1964.

Secondary Works

Abrams, Dominic and Michael Hogg, Social Identifications: A Social Psychology of Intergroup Relations and Group Processes. London: Routledge, 2006.

Adler, Gillian, 'Female Intercession and the Shaping of Male Heroism in the Roman d'Enéas and Le chevalier au lion', Medieval Feminist Forum: A Journal of Gender and Sexuality 49.2 (2013), 70-87.

Airlie, Stuart, 'The History of Emotion and Emotional History', Early Medieval Europe 10.2 (2001), 235-41.

Almazan, Vincent, 'Translations at the Castilian and Norwegian Courts in the Thirteenth Century: Parallels and Patterns', Medieval Scandinavia, 12 (1988), 213-32.

Althoff, Gerd, 'Tränen und Freude: Was interessiert Mittelalter-Historiker an Emotionen?', Frühmittelalterliche Studien 40 (2006), 1-11.

Alver, Bente G., 'Concepts of the Soul in Norwegian Tradition', in Nordic Folklore: Recent Studies, ed. Reimund Kvideland and Henning K. Semsdorf. Bloomington: Indiana University Press, 1989, 110-27.

Andersson, Theodore, The Icelandic Family Saga: An Analytic Reading. Cambridge, Mass: Harvard University Press, 1967. 
Arnold, Magda B., Emotion and Personality, vol. 1: Psychological Aspects, vol. 2:

Neurological and Psychological Aspects. New York: Columbia University Press, 1960.

Aussems, Mark, 'Spiegelpersonages in Chrétiens Le chevalier de la charrette', Madoc 21.2 (2007), 23-31.

Austin, John L., How to do Things with Words. Cambridge, Mass: Harvard University Press, 1962.

Averill, James R., ‘A Constructivist View of Emotion', in Emotion: Theory, Research, and Experience, ed. Robert Plutchik and Henry Kellerman. New York: Academic Press, 1980, 305-39.

Baccianti, Sarah, 'Swelling in Anger: Somatic Descriptors in Old English and Old Norse Literature', in Emotion and Medieval Textual Media, ed. Mary C. Flannery. Turnhout: Brepols, 2018, 51-73.

Bampi, Massimiliano, Carolyne Larrington and Sif Rikharsdottir, eds, A Critical Companion to Old Norse Literary Genre. Woodbridge: Boydell \& Brewer, 2020.

Bandlien, Bjørn, ‘Arthurian Knights in Fourteenth-Century Iceland: Erex saga and Ívens saga in the World of Ormur Snorrason', Arthuriana 23.4 (2013), 6-37.

—- Strategies of Passion: Love and Marriage in Medieval Iceland and Norway. Turnhout: Brepols, 2005.

Barnes, Geraldine, 'Some Current Issues in Riddarasögur Research', Arkiv för nordisk filologi 104 (1989), 73-88.

__ , 'The "Discourse of Counsel" and "Translated" Riddarasögur', in Learning and Understanding in the Old Norse World: Essays in Honour of Margaret Clunies Ross, ed. Judy Quinn, Kate Heslop and Tarrin Wills. Turnhout: Brepols, 2007, 375-97. 
__, 'The Riddarasögur: A Medieval Exercise in Translation', Saga Book of the Viking Society for Northern Research 19 (1974), 403-41.

—_, 'The Riddarasögur and Mediæval European Literature', Mediaeval Scandinavia 8 (1975), 141-58.

Barrett, Karen C., 'The Development of Nonverbal Communication of Emotion: A Functionalist Perspective', Journal of Nonverbal Behavior 17.3 (1993), 145-69.

Barron, W. R. J., 'Chrétien and the Gawain-Poet: Master and Pupil or Twin Temperament?', in The Legacy of Chrétien de Troyes, ed. Norris J. Lacy, Douglas Kelly and Keith Busby, vol. 2. Amsterdam: Rodopi, 1988, 255-84.

Bassnett, Susan, Translation Studies, $3^{\text {rd }}$ edn. London/New York: Routledge, 2002.

Bastert, Bernd, Der Münchner Hof und Fuetrers Buch der Abenteuer: Literarische Kontinuität im Spätmittelalter. Mikrokosmos, Beiträge zur Literaturwissenschaft und Bedeutungsforschung 33. Frankfurt am Main: Peter Lang, 1993.

Baumgartner, Emmanuèle, 'Chrétien's Medieval Influence', in A Companion to Chrétien de Troyes, ed. Norris Lacy and Joan Tasker Grimbert. Cambridge, UK: D.S. Brewer, $2005,214-27$.

Beer, Jeanette, Beasts of Love: Richard de Fournival's Bestiaire d'amour and the Response.

Toronto: University of Toronto Press, 2003.

—_, Master Richard's Bestiary of Love and Response. West Hatfield, Mass: Pennyroyal Press, 1985.

Benjamin, Walter, 'The Task of the Translator', in Illuminations, ed. Hannah Arendt, trans. Harry Zohn. New York: Schoken Books, 1969, 69-82.

Benton, John F., 'Clio and Venus: An Historical View of Medieval Love', The Meaning of Courtly Love, ed. Francis X. Newman. New York: State University of New York Press, 1968, 19-42. 
—_ 'The Court of Champagne as a Literary Centre', Speculum 36 (1961), 551-91.

Besamusca, Bart, 'Readership and Audience', in Handbook of Arthurian Romance, ed. Leah

Tether and Johnny McFadyen. Berlin: De Gruyter, 2017, 117-32.

Besamusca, Bart and Gerard Sonnemans, 'De crumen diet volc niet eten en mochte':

Nederlandse beschouwingen over vertalen tot 1550. Vertaalhistorie 6. 's-Gravenhage:

Stichting Bibliographia Neerlandica, 1999.

Besamusca, Bart and Jessica Quinlan, ‘The Fringes of Arthurian Fiction', Arthurian Literature 29 (2012), 192-242.

Bezzola, Retro, Le Sens du l'aventure et de l'amour. Paris: La Jeune Parque, 1947.

Bloch, Marc, Feudal Society, trans. L.A. Manyon. Chicago: Chicago University Press, 1961.

—- Rois et serfs: Un chapitre d'histoire capétienne. PhD dissertation, Paris, 1920.

Bolens, Guillemette, The Style of Gestures: Embodiment and Cognition in Literary Narrative. Baltimore: John Hopkins University Press, 2012.

le Bon, Gustave, Psychologie des foules, ed. Félix Alcan. Paris: 1895.

_- The Crowd: A Study of the Popular Mind. New York: Cosimo Classics, 2006 [first translated 1896].

Bonheim, Helmut, ‘The Acromegalic in Chrétien's Yvain', French Studies 44.1 (1990), 1-9.

Bordwell, David, Narration in the Fiction Film. Madison: University of Wisconsin Press, 1985.

Bornholdt, Claudia, "'Everyone thought it very strange how the man had been shaped": The Hero and his Physical Traits in the Riddarasögur', Arthuriana 22.1 (2012), 18-38.

—_ 'The Old Norse-Icelandic Transmission of Chrétien de Troyes's Romances: Ívens saga, Erex saga, Parcevals saga with Valvens páttr', in The Arthur of the North: The Arthurian Legend in the Norse and Rus' Realms, ed. Marianne E. Kalinke. Cardiff: University of Wales Press, 2011, 98-122.

Bossuat, Robert, ed., Dictionnaire des lettres françaises: Le Moyen Âge. Paris: Fayard, 1964. 
Brandsma, Frank, 'blide ende drove: Mixed Emotions in Middle Dutch Arthurian Romance', Journal of the International Arthurian Society 4.1 (2016), 104-12.

—_ 'La véridicité des émotions dans le Perchevael, transposition en moyen néerlandais du Conte du Graal: Les larmes de Perchevael', in Fictions de vérité dans les réécritures européennes des romans de Chrétien de Troyes, ed. Annie Combes. Paris: Garnier, Fictions de vérité, 2012, 157-71.

__ 'Luisteren naar de Spiegel', in Maar er is meer: Avontuurlijk lezen in de epiek van de Lage Landen, ed. Remco Sleiderink, Veerle Uyttersprot en Bart Besamusca. Amsterdam: Davidfonds, Amsterdam University Press, 2005, 283-301.

—_, 'Mirror Characters', in Courtly Arts and the Art of Courtliness, ed. Keith Busby and Christopher Kleinhenz. Cambridge, UK: D.S. Brewer, 2006, 275-82.

—_, 'Spiegelpersonages', in Hoort Wonder! Opstellen voor W.P. Gerritsen bij zijn emeritaat, ed. Bart Besamusca, Frank Brandsma and Dieuwke van der Poel. Hilversum: Verloren, 2000, 37-42.

— , 'The Court's Emotions', in Cultures courtoises en mouvement, ed. Isabelle Arseneau and Francis Gingras. Montréal: Presses de l’Université de Montréal, 2010, 74-82.

— the North?', in Arthur of the North: Histories, Emotions, and Imaginations, ed. Bjørn Bandlien, Stefka G. Eriksen and Sif Rikhardsdottir, special issue of Scandinavian Studies 87.1 (2015), 94-106.

Brandsma, Frank, Carolyne Larrington and Corinne Saunders, eds, Emotions in Medieval Arthurian Literature: Body, Mind, Voice. Arthurian Studies 83. Cambridge: D.S. Brewer, 2015.

Branscombe, Nyla R. and Bertjan Doosje, eds, Collective Guilt: International Perspectives (Studies in Emotion and Social Interaction). New York: Cambridge University Press, 
2004.

Brault, Gerard J., 'Chrétien de Troyes's Lancelot: The Eye and the Heart', Bulletin bibliographique de la Société internationale arthurienne 24 (1972), 142-53.

Brazil, Sarah, 'The Materiality of Metaphors: Why the Affectus Needs Shoes in The Doctrine of the Hert', in Emotion and Medieval Textual Media, ed. Mary C. Flannery. Turnhout: Brepols, 2018, 177-93.

Bremmer Jan N. and Herman W. Roodenburg, eds, A Cultural History of Gesture from Antiquity to the Present Day. Cambridge, UK: Polity Press, 1993.

Brown, Arthur C.L., Iwain: A Study of the Origins of Arthurian Romance. Boston: Ginn \& Co., 1903.

Bumke, Joachim, 'Der unfeste Text, Überlegungen zur Überlieferungsgeschichte und Textkritik der höfischen Epik im 13. Jahrhundert,' in 'Aufführung' und 'Schrift' in Mittelalter und Früher Neuzeit, ed. Jan-Dirk Müller. Stuttgart: Weimar, 1996, 118 29.

— Die vier Fassungen der Nibelungenklage: Untersuchungen zur Überlieferungsgeschichte und Textkritik der höfischen Epik im 13. Jahrhundert. Quellen und Forschungen 8. Berlin: De Gruyter, 1996.

—_, Höfische Kultur: Literatur und Gesellschaft im hohen Mittelalter. München: Deutscher Taschenbuch Verlag, 1986.

Burns, Jane E., 'The Man behind the Lady in Troubadour Lyric', Romance Notes 25.3 (1985), 254-70.

Burrow, John, Gestures and Looks in Medieval Narrative. Cambridge UK: Cambridge University Press, 2002.

Busby, Keith, 'Chrétien de Troyes English'd', Neophilologus 71.4 (1987), 596-613. 
_ ' 'The Manuscripts of Chrétien's Romances', in A Companion to Chrétien de Troyes, ed. Norris Lacy and Joan Tasker Grimbert. Cambridge, UK: D.S. Brewer, 2005, 64-75.

Busby, Keith, Terry Nixon, Alison Stones and Lori Walters, eds, Les manuscrits de Chrétien de Troyes/The Manuscripts of Chrétien de Troyes, 2 vols. Amsterdam/Atlanta, GA: Rodopi, 1993, vol. 1, 17-25.

Caers, Bram, 'Een buchelin inn flemische: Over ontstaan en verspreiding van de ridderepiek in de Nederlanden (ca. 1150-1450)', Tijdschrift voor Nederlandse Taal- en Letterkunde 127.3 (2011), 223-51.

Caers, Bram and Mike Kestemont, 'The Cultural and Historical Context of the Low Countries', in The Arthur of the Low Countries: The Arthurian Legend in Dutch and Flemish Literature, ed. Bart Besamusca and Frank Brandsma. Cardiff: University of Wales Press, 2021, 7-30.

Caluwé-Dor, Julliette de, 'Yvain's Lion Again: A Comparative Analysis of its Personality and Function in the Welsh, French and English Versions', in An Arthurian Tapestry: Essays in Memory of Lewis Thorpe, ed. Kenneth Varty. Glasgow: University of Glasgow, 1981, 229-38.

Campbell, Emma and Robert Mills, eds, Rethinking Medieval Translation: Ethics, Politics, Theory. Cambridge, UK: D.S. Brewer, 2012.

Carroll, Carleton W., 'Quelques observations sur les reflets de la cour d'Henri II dans l'oeuvre de Chrétien de Troyes', Cahiers de Civilisation Médiévale 37 (1994), 33-39. Carruthers, Mary J., The Book of Memory: A Study of Memory in Medieval Culture. Cambridge Studies in Medieval Literature 10. Cambridge, UK: Cambridge University Press, 1990.

Cerquiglini, Bernhard, Éloge de la variante: Histoire critique de la philologie. Paris: Editions de Seuil, 1989. 
—, In Praise of the Variant: A Critical History of Philology, trans. Betsy Wing. Baltimore: John Hopskins University Press, 1999.

Chênerie, Marie-Luce, Le chevalier errant dans les romans arthuriens en vers des 12 e et 13 e siècles. Geneva: Droz, 1986.

Claassens, Geert H.M and David F. Johnson, eds, King Arthur in the Medieval Low Countries. Leuven: Leuven University Press, 2000.

Clark, Andy, 'Spreading the Joy?', Mind 118 (2009), 963-93.

Cline, Ruth, 'Heart and Eyes', Romance Philology 25 (1972), 263-97.

Clunies Ross, Margaret, “"Fimm líkamsins vit”: The Development of a New Lexical Set in Early Norse Christian Literature', Arkiv för nordisk filologi 102 (1987), 197-206.

Colapietro, Vincent, 'The Poetics of Experience', in The Translator as Mediator of Cultures, ed. Humphrey Tonkin and Maria Esposito Frank. Amsterdam: John Benjamins Publishing Company, 2010, 107-24.

Cook, Robert, 'Concepts of Love in the Lais and in their Norse Counterparts', in Francia et Germania: Studies in Strengleikar and Piðreks saga af Bern, ed. Karl G. Johansson and Rune Flaten. Bibliotheca Nordica 5. Oslo: Novus Forlag, 2012, 53-86.

Copeland, Rita, Rhetoric, Hermeneutics, and Translation in the Middle Ages: Academic Traditions and Vernacular Texts. Cambridge Studies in Medieval Literature 11. Cambridge, UK: Cambridge University Press, 1991.

Curschmann, Michael, 'Der aventiure bilde nemen: The Intellectual and Social Environment of the Iwein Murals at Rodenegg Castle', in Chrétien de Troyes and the German Middle Ages, ed. Martin Johnes and Roy Wisbey. Cambridge, UK: D.S. Brewer, 1993, 219-27.

Damasio, Antonio, The Feeling of what Happens: Body and Emotion in the Making of Consciousness. New York: Harcourt Brace \& Company, 1999. 
Darwin, Charles, The Expressions of the Emotions in Man and Animals, 3rd ed. London: Harper Collins Publishers, 1872 [repr. 1998].

Davies, Sioned, 'Written Text as Performance: The Implications for Middle Welsh Prose Narratives', in Literacy in Medieval Celtic Societies, ed. Huw Pryce. Cambridge, UK: Cambridge University Press, 1988, 133-48.

Dembowski, Peter, 'Monologue, Author's Monologue and Related Problems in the Romances of Chrétien de Troyes', Approaches to Medieval Romance, Yale French Studies 51 (1974), 102-14.

Dixon, Thomas, From Passions to Emotions: The Creation of a Secular Psychological Category. Cambridge, UK: Cambridge University Press, 2003.

Dow, Jamie, 'Aristotle's Theory of the Emotions: Emotions as Pleasures and Pains', in Moral Psychology and Human Action in Aristotle, ed. Michael Pakaluk and Giles Pearson. New York: Oxford University Press, 2011, 48-74.

Duggan, Joseph, The Romances of Chrétien de Troyes. New Haven: Yale University Press, 2001.

Durkheim, Émile, Les formes élémentaires de la vie religieuse. Paris: Félix Alcan, 1912.

- The Elementary Forms of the Religious Life, trans. Joseph Ward Swain. London: Allen \& Unwin, 1912

Eco, Umberto, Mouse or Rat? Translation as Negotiation. London: Weidenfeld \& Nicolson, 2003.

Eden, Kathy, Poetic and Legal Fiction in the Aristotelian Tradition. Princeton: Princeton University Press, 1986.

Ekman, Paul, 'Basic Emotions', in Handbook of Cognition and Emotion, ed. Tim Dalgleish and Mick J. Power. Chichester: John Wiley and Sons, 1999, 45-60. 
Ekman, Paul and Wallace V. Friesen, 'Constants across Cultures in the Face and Emotion', Journal of Personalty and Social Psychology 17 (1971), 124-29.

Eldjárn, Kristján, Hundrað ár i Pjóðminjasafni. Reykjavík: Mál og menning, 1994.

Elias, Norbert, The Civilising Process: The History of Manners and State Formations and Civilisations, trans. Edmund Jephcott. Oxford: Blackwell, 1994.

—_ Über den Prozeß der Zivilisation, 2 vols. Basel: Verlag Haus zum Falken, 1939.

Emming, Jutta, 'Emotionen als Gegenstand mediävistischer Literaturwissenschaft', Journal of Literary Theory 1.2 (2007), 251-73.

Enders, Jody, 'Memory and the Psychology of the Interior Monologue of Chrétien's Cligès', Rhetorica 10.1 (1992), 5-23.

Eriksen, Stefka G., Writing and Reading in Medieval Manuscript Culture: The Translation and Transmission of the Story of Elye in Old French and Old Norse Literary Contexts. Turnhout: Brepols, 2014.

Favati, Guido, 'Una traccia di cultura neoplatonica in Chrétien de Troyes: Il tema degli occhi come specchio', in Studi in onore di Carlo Pellegrini, Biblioteca di studi francesi. Torino: Società editrice internazionale, 1963, 3-13.

Ferm, Olle, 'The Emergence of Courtly Literature in Sweden: A Critical Discussion of Swedish Research', in The Eufemiavisor and Courtly Culture: Time, Texts and Cultural Transfer. Papers from a Symposium in Stockholm 11-13 October 2012, ed. Olle Ferm, Ingela Hedström, Sofia Lodén, Jonatan Pettersson and Mia Åkestam. Stockholm: Kungl. Vitterhets historie och antikvitets akademien, 2015, 109-20. Ferm, Olle, Ingela Hedström, Sofia Lodén, Jonatan Pettersson, and Mia Åkestam, eds, The Eufemiavisor and Courtly Culture: Time, Texts and Cultural Transfer. Kungliga Vitterhets Historie och Antikvitets Akademien Konferenser, 88. Stockholm: Kungliga Vitterhetsakademien, 2015. 
Fidjestøl, Bjarne, 'Romantic Reading at the Court of Håkon Håkonsson', in Selected Papers, ed. Odd Einar Haugen and Else Mundal, trans. Peter Foote. Odense: Odense University Press, 1997, 351-65.

Fischer, Agneta, Over de zin en onzin van emoties. Amsterdam: Bert Bakker, 2010.

Fisher, Rodney, 'Erecs Schuld und Enites Unschuld bei Hartmann', Euphorion 69 (1975), $160-174$.

Foster, Idris, 'Geraint, Owain and Peredur', in Arthurian Literature in the Middle Ages, ed. Roger Sherman Loomis. Oxford: Clarendon Press, 1959, 192-205.

Fourrier, Anthime, 'Encore la chronologie des oeuvres de Chrétien de Troyes', Bulletin bibliographique de la Sociéte internationale Arthurienne 2 (1950), 69-88.

Frappier, Jean, Étude sur Yvain ou le chevalier au lion de Chrétien de Troyes. Paris: Sedes, 1969.

$\ldots$, Le roman breton: Yvain ou le chevalier au lion. Paris: Centre de documentation universitaire, 1952.

Frijda, Nico H., De emoties: Een overzicht van onderzoek en theorie. Amsterdam: Bert Bakker, 1988.

— The Emotions. Studies in Emotion and Social Interaction. Cambridge/New York: Cambridge University Press, Paris: Maison des sciences du l'homme, 1986.

—_, 'The Laws of Emotion', American Psychologist 43 (1988), 349-58; repr. in Human Emotions, ed. Jennifer Jenkins, Keith Oatley and Nancy L. Stein. Oxford: WileyBlackwell, 1998, 270-80.

__ The Laws of Emotion. Mahwah, NJ: Lawrence Erlbaum Associates, 2007.

Fromm, Hans, 'Doppelweg', in Arbeiten zur deutschen Literatur des Mittelalters, ed. Hans Fromm. Tübingen: Max Niemeyer Verlag, 1989, 122-36. 
Garrison, Mary, 'The Study of Emotions in Early Medieval History: Some Starting Points', Early Medieval Europe 10.2 (2001), 243-50.

Gärtner, Kurt, 'Die Zwettler Erec-Fragmente: Versuch einer ersten Auswertung', in Literatur als Erinnerung. Winfred Woesler zum 65. Geburtstag, ed. Bodo Plachta. Tübingen: Niemeyer, 2004, 35-50.

Geertz, Clifford, The Interpretation of Cultures: Selected Essays. New York: Basic Books, 1973.

Gentry, Francis G., ed., A Companion to the Works of Hartmann von Aue. Rochester, NY: Boydell \& Brewer/Camden House, 2005.

Gerritsen, Wim P., 'Les relations littéraires entre la France et les Pays-Bas au Moyen Âge: Quelques observations sur la technique de traducteurs', in Actes du septième congrès national de la Société Française de Littérature Comparée, Poitiers 27-29 mai 1965. Paris: Didier, 1967, 28-46.

Glauser, Jürg, 'Romance-A Case Study', in A Critical Companion to Old Norse Literary Genre, ed. Massimiliano Bampi, Carolyne Larrington and Sif Rikharsdottir. Woodbridge: Boydell \& Brewer, 2020, 299-312.

le Goff, Jacques, La civilisation de l'Occident médiéval. Paris: Arthaud, 1964.

—, Medieval Civilisation 400-1500, trans. Julia Barrow. Oxford/Cambridge/ Massachusetts: Basil Blackwell, 1988.

Gordon, Sarah E., 'The Man with No Name: Identity in French Arthurian Verse Romance', Arthuriana 18.2 (2008), 69-81.

Green, Dennis H., Irony in the Medieval Romance. Cambridge, UK: Cambridge University Press, 2003.

—. Women and Marriage in German Medieval Romance. Cambridge, UK: Cambridge University Press, 2009. 
Grenzler, Thomas, Erotisierte Politik-Politisierte Erotik?: Die politisch-ständische Begründung der Ehe-Minne in Wolframs Willehalm, im Nibelungenlied und in der Kudrun. Göppinger Arbeiten zur Germanistik 522. Göppingen: Kümmerle Verlag, 1992.

Grosse, Siegfried, 'Die Variationen der Minne in den Dichtungen Hartmanns von Aue', in Interpretation und Edition deutscher Texte des Mittelalters: Festschrift für John Asher, ed. Kathryn Smits, Werner Besch and Victor Lange. Berlin: Erich Schmidt Verlag, 1981, 26-38.

Haase, Julia, Das 'verligen' und das daraus resultierende Schweigegebot im Erec Hartmanns von Aue. München: GRIN Verlag, 2010.

Haidu, Peter, Aesthetic Distance in Chrétien de Troyes: Irony and Comedy in Cligès and Perceval. Geneva: Librairie Droz, 1968.

_ 51 (1974), 133-46.

Hallberg, Peter, 'Broder Robert, Tristrams saga och Duggals leizla: Anteckningar till norska översättningar’, Arkiv för nordisk filologi 88 (1973), 55-71.

—_, 'Norröna riddarsagor: Några språkdrag', Arkiv för nordisk filologi 86 (1971), 114-37. Halvorsen, Eyvind Fjeld, ‘Translation - Adaptation - Imitation', Mediaeval Scandinavia 7 (1974), 556-60.

Harré, Rom, The Social Construction of Emotions. Oxford: Wiley-Blackwell, 1988.

Hasty, Will, 'Hartmann von Aue as Lyricist', in A Companion to the Works of Hartmann von Aue, ed. Francis G. Gentry. Rochester, NY: Boydell \& Brewer/Camden House, 2005, $21-42$.

— , 'The Allure of Otherworlds: The Arthurian Romances in Germany', in A Companion to Arthurian Literature, ed. Helen Fulton. Oxford: Wiley-Blackwell, 2009, 175-88. 
Haug, Walter, 'Das Land von welchem niemand wiederkehrt': Mythos, Fiktion und

Wahrheit in Chrétiens Chevalier de la charrette, in Lanzelet Ulrichs von Zatzikhoven und im Lancelot Prosaroman. Untersuchungen zur deutschen Literaturgeschichte 21. Tubingen: Max Niemeyer Verlag, 1978.

—_ ' 'Die Symbolstruktur des höfischen Epos und ihre Auflösung bei Wolfram von Eschenbach', Deutsche Vierteljahrsschrift für Literaturwissenschaft und Geistesgeschichte 45 (1971), 668-705.

Heinrichs, Heinrich Matthias, Iwein Handschrift B. Deutsche Texte in Handschriften 2. Köln, Graz: Böhlau Verlag, 1964.

Helle, Knut, 'Anglo-Norwegian Relations in the Reign of Håkon Håkonsson (1217-63)', Medieval Scandinavia 1 (1968), 101-14.

— Press, 2003.

Hermann, Pernille, 'Memory, Imagery, and Visuality in Old Norse Literature', The Journal of English and Germanic Philology 114.3 (2015), 317-40.

Hochschild, Arlie R., 'Emotion Work, Feeling Rules, and Social Structures', American Journal of Sociology 85.3 (1979), 551-75.

Hogan, Patrick Colm, The Mind and its Stories: Narrative Universals and Human Feeling. Cambridge, UK: Cambridge University Press, 2003.

—, What Literature Teaches Us about Emotion. Cambridge, UK: Cambridge University Press, 2011.

Holland, Norman N., Literature and the Brain. Gainesville, Florida: The PsyArt Foundation, 2009.

Holyst, Janusz A., ed., Cyberemotions: Collective Emotions in Cyberspace. Berlin: Springer, 2017. 
Høystad, Ole Martin, A History of the Heart. London: Reaktion Books, 2009.

Hrubý, Antonín, 'Die Problemstellung in Chrétiens und Hartmanns Erec', in Hartmann von Aue, ed. Hugo Kuhn and Christoph Cormeau. Darmstadt: Wisschenschaftliche Buchgesellschaft, 1973, 342-72.

Huebner, Bryce, 'Genuinely Collective Emotions', European Journal for the Philosophy of Science 1 (2011), 89-118.

Huizinga, Johan, Herfsttij der Middeleeuwen. Amsterdam: Olympus, Atlas Contact, 2017 [first published 1919].

— The Waning of the Middle Ages. New York: Doubleday Anchor Books, 1954.

Hunt, Tony, 'Beginnings, Middles and Ends: Some Interpretative Problems in Chrétien’s Yvain and its Medieval Adaptations', in The Craft of Fiction: Essays in Medieval Poetics, ed. Leigh A. Arrathoon. Rochester, MI: Solaris Press, 1984, 83-117.

$\longrightarrow$ Chrétien de Troyes: Yvain (Le chevalier au lion). Critical Guides to French Texts 55. London: Grant \& Cutler, 1986.

—_, 'Herr Ivan Lejonriddaren', Mediaeval Scandinavia 8 (1975), 168-86.

— Arthurienne 30 (1978), 209-37.

Hutcheon, Linda with Siobhan O'Flynn, A Theory of Adaptation. London/New York: Routledge, 2013.

Hutchison, Emma, Affective Communities in World Politics: Collective Emotions after Trauma. Cambridge: Cambridge University Press, 2016.

Irlenbusch-Reynard, Liliane, 'Translations at the Court of Hákon Hákonarson: A Well Planned and Highly Selective Programme', Scandinavian Journal of History 36.4 (2011), 387-405. 
Jackson, Harry and Silvia Ranawake, eds, The Arthur of the Germans: The Arthurian Legend in Medieval German and Dutch Literature. Cardiff: University of Wales Press, 2000.

Jacobs, Molly, “"Hon stóð ok starði”: Vision, Love, and Gender in Gunnlaugs saga Ormstungu', Scandinavian Studies 86.2 (2014), 148-68.

—_ “ “Undir ilmöndum laufum ok nýsprungnum blómstrum”: Sensual Pleasure in Old Norse Arthurian Romance', in Arthur of the North: Histories, Emotions, and Imaginations, ed. Bjørn Bandlien, Stefka G. Eriksen and Sif Rikhardsdottir, special issue of Scandinavian Studies 87.1 (2015), 107-28.

Jaeger, Stephen C., Ennobling Love: In Search of a Lost Sensibility. Philadelphia, PA: University of Pennsylvania Press, 1999.

- The Origins of Courtliness: Civilizing Trends and the Formation of Courtly Ideals 9391210. Philadelphia, PA: University of Pennsylvania Press, 1985.

Jaeger, Stephen C. and Ingrid Kasten, eds, Codierungen von Emotionen im Mittelalter/Emotions and Sensibilities in the Middle Ages. Berlin: De Gruyter, 2003. James, William, The Principles of Philosophy, 2 vols. New York: Henry Holt and Company, 1890.

—, 'What is an Emotion?', Mind 9 (1884), 188-205.

Jansson, Valter, Eufemiavisorna: En filologisk undersökning. Uppsala/Leipzig: Lundequistska bokhandeln/Harrassowitz, 1945.

Jonin, Pierre, Prolégomènes à une edition d'Yvain. Publications des annals de la Faculté des Lettres, Aix-en-Provence 19. Gap: Editions Ophrys, 1958.

Jordan, Nicola, 'Eine alte und doch immer neue Geschichte: Die Ívents saga Artúskappa und der Iwein Hartmanns von Aue als Bearbeitungen von Chrétiens Yvain', in Übersetzen im skandinavischen Mittelalter, ed. Vera Johanterwage and Stefanie Würth. Studia Medievalia Septentrionalia 14. Vienna: Verlage Fassbaender, 2007, 141-66. 
Jütte, Robert, A History of the Senses. Cambridge, UK: Polity Press, 2005.

Kalinke, Marianne E., 'Alliteration in Ívens saga', Modern Language Review 74 (1979), $871-83$.

_ _ 'Honor: The Motivating Principle of the Erex saga', Scandinavian Studies 45 (1973), $135-43$.

— King Arthur, North-by-Northwest: The 'matière de Bretagne' in Old Norse-Icelandic Romances. Bibliotheca Arnamagnæana 37. Copenhagen: C.A. Reitzels Boghandel, 1981.

—

—, 'Sources, Translations, Redactions, Manuscript Transmission', in The Arthur of the North: The Arthurian Legend in the Norse and Rus'Realms, ed. Marianne E. Kalinke. Cardiff: University of Wales Press, 2011, 22-47.

—, ed., The Arthur of the North: The Arthurian Legend in the Norse and Rus' Realms. Arthurian Literature in the Middle Ages 5. Cardiff: University of Wales Press, 2011.

— 'The Introduction of the Arthurian Legend in Scandinavia', in The Arthur of the North: The Arthurian Legend in the Norse and Rus' Realms, ed. Marianne E. Kalinke. Cardiff: University of Wales Press, 2011, 1-10.

Kanerva, Kirsi, 'Disturbances of the Mind and Body: Effects of the Living Dead in Medieval Iceland', in Mental (Dis)Order in Later Medieval Europe, ed. Sari Katajala-Peltomaa and Susanna Niiranen. Leiden/Boston: Brill, 2014, 219-42.

Kay, Sarah, 'Who was Chrétien de Troyes?', in Arthurian Literature, ed. James P. Carley and Felicity Riddy, vol. 15. Cambridge: D.S. Brewer, 1997, 1-36.

Kärkkäinen, Pekka, 'The Senses in Philosophy and Science: Mechanics of the Body or Activity of the Soul?', in A Cultural History of the Senses in the Middle Ages, ed. 
Richard G. Newhauser. London/New Delhi/New York/Sydney: Bloomsbury, 2014, $111-32$.

Keen, Suzanne, ‘A Theory of Narrative Empathy', Narrative 14 (2006), 209-36.

Kelly, Douglas, 'Chrétien de Troyes', in The Arthur of the French: The Arthurian Legend in Medieval French and Occitan Literature, ed. Glyn S. Burgess and Karen Pratt. Cardiff: University of Wales Press, 2006, 135-85.

— , 'Narrative Poetics: Rhetoric, Orality and Performance', in A Companion to Chrétien de Troyes, ed. Norris Lacy and Joan Tasker Grimbert. Cambridge, UK: D.S. Brewer, 2005, 52-63.

—, The Art of Medieval French Romance. Madison: University of Wisconsin Press, 1992. Keysers, Christian et al., 'A Touching Sight: SII/PV Activation during the Observation and Experience of Touch', Neuron 42.2 (2004), 335-46.

King, Peter, 'Emotions in Medieval Thought', in The Oxford Handbook of Philosophy of Emotions, ed. Peter Goldie. Oxford/New York: Oxford University Press, 2010, 16780.

Kjær, Jonna, 'Franco-Scandinavian Literary Transmission in the Middle Ages: Two Old Norse Translations of Chrétien de Troyes-Ívens saga and Erex saga', in The Arthurian Yearbook, ed. Keith Busby, vol. 2. New York: Garland, 1992, 113-34.

— Roland/Af Rúnzivals bardaga: Une epopée féodale transformée en roman courtois?' Romania 114 (1996), 50-69.

Klein, Thomas, 'Ermittlung, Darstellung und Deutung von der Handschriftenüberlieferung mittelhochdeutscher Epik', in Deutsche Handschriften 1100-1400, Oxforder Kolloquium 1985, ed. Volker Honeman and Nigel F. Palmer. Tübingen: Niemeyer, $1988,110-67$. 
Knuuttilla, Simo, 'Aristotle's Theory of Perception and Medieval Aristotelianism', in Theories of Perception in Medieval and Early Modern Philosophy. Dordrecht: Springer, 2008.

— Emotions in Ancient and Medieval Philosophy. Oxford: Oxford University Press, 2004. Kolb, Herbert, 'Die Mystik des Auges und Herzens', in Der Begriff der Minne und das Entstehen der höfischen Lyrik, ed. Herbert Kolb, Helmut de Boor and Hermann Kunisch. Tübingen: Max Niemeyer Verlag, 1958, 18-38.

Konzelmann Ziv, Anita, 'The Semantics of Shared Emotion', Universitas Philosophica 26.52 (2009), 81-106.

Kratins, Ojars, 'Love and Marriage in Three Versions of "The Knight with the Lion"”, Comparative Literature 16 (1964), 29-39.

—, The Dream of Chivalry: A Study of Chrétien de Troyes's Yvain and Hartmann von Aue's Iwein. Washington, D.C.: University Press of America, 1982.

Krause, Burkhardt, 'Zur Psychologie von Kommunikation und Interaktion: Zu Iweins "Wahnsinn"”, in Psychologie in der Mediävistik: Gesammelte Beidrage des Steinheimer Symposion, ed. Jürgen Kuhnel et al. Göppingen: Kümmerle, 1985, 21542.

Kretschmer, Bernd, Höfische und altwestnordische Erzähltradition in den Riddarasögur: Studien zur Rezeption der altfranzösischen Artusepik am Beispiel der Erex saga, Ívens saga und Parcevals saga. Hattingen: Verlag Dr. Bernd Kretschmer, 1982.

Kristjánsson, Jónas, Eddas and Sagas: Iceland's Medieval Literature, trans. Peter Godfrey Foote, 4th edn. Reykjavík: Hiđ íslenska bókmenntafélag, 2007 [first published 1988]. Krueger, Roberta L., 'Chrétien de Troyes and the Invention of Arthurian Courtly Fiction', in A Companion to Arthurian Literature, ed. Helen Fulton. Malden, MA/Oxford: WileyBlackwell, 2009, 160-74. 
_ , 'Introduction', in The Cambridge Companion to Medieval Romance, ed. Roberta Krueger. Cambridge, UK: Cambridge University Press, 2000, 1-12.

Kuhn, Hugo, Dichtung und Welt im Mittelalter. Stuttgart: Metzler, 1969.

Kuttner, Ursula, Das Erzählen des Erzählten: Eine Studie zum Stil in Hartmanns Erec und Iwein. Studien zur Germanistik, Anglistik und Komparatistik 70. Bonn: Bouvier, 1978.

Kutz, Christopher, Complicity: Ethics and Law for a Collective Age. Cambridge, UK: Cambridge University Press, 2001.

Lange, Carl G., 'The Emotions: A Physiological Study', in The Emotions, ed. Carl G. Lange and William James. New York: Hafner, 1885, 33-90.

Larrington, Carolyne, 'Learning to Feel in the Old Norse Camelot?', in Arthur of the North: Histories, Emotions, and Imaginations, ed. Bjørn Bandlien, Stefka G. Eriksen and Sif Rikhardsdottir, special issue of Scandinavian Studies 87.1 (2015), 74-94.

_ 'The Psychology of Emotion and Study of the Medieval Period', Early Medieval Europe 10.2 (2001), 251-56.

_ , 'The Translated Lais', in The Arthur of the North: The Arthurian Legend in the Norse and Rus' Realms, ed. Marianne E. Kalinke. Cardiff: University of Wales Press, 2011, $77-97$.

__ , "Wyze, welcum iwys to pis place!": Emotions in the Schemas for Arrival, Return and Welcome at the Arthurian Court', Journal of the International Arthurian Society 4.1 (2016), 92-103.

Lassen, Annette, Øjet og Blindheden i Norrøn litteratur og mythologi. Copenhagen: Museum Tusculanums Forlag, 2003. 
Layher, William, 'The Old Swedish Hoerra Ivan Leons Riddare', in The Arthur of the North: The Arthurian Legend in the Norse and Rus' Realms, ed. Marianne E. Kalinke. Cardiff: University of Wales Press, 2011, 123-44.

—, Queen Eufemia's Legacy: Middle Low German Literary Culture, Royal Patronage and the First Old Swedish Epic (1301). PhD dissertation, Harvard University, 1999.

—., Queenship and Voice in Medieval Northern Europe. New York: Palgrave MacMillan, 2010.

Leach, Henry Goddard, Angevin Britain and Scandinavia. Harvard Studies in Comparative Literature 6. Cambridge, Mass: Harvard University Press, 1921.

Leverage, Paula, Howard Mancing, Richard Schweickert, and Jennifer Marston William, eds, Theory of Mind and Literature. West Lafayette, Indiana: Purdue University Press, 2011.

Lloyd-Morgan, Ceridwen, 'French Text, Welsh Translators', in The Medieval Translator, ed. Roger Ellis, vol. 2. London: Centre for Medieval Studies, Queen Mary and Westfield College, University of London, 1991, 45-63.

Lodén, Sofia, Le chevalier courtois à la rencontre de la Suède médiévale: Du Chevalier au lion $\grave{a}$ Herr Ivan. PhD dissertation, Stockholm University, 2012.

__ ' 'Rewriting Le chevalier au lion: Different Stages of Literary Transmission', in Riddarasögur: The Translation of European Court Culture in Medieval Scandinavia, ed. Karl G. Johansson and Else Mundal. Oslo: Novus, 2014, 91-106.

— , 'The Arthurian Legacy in Sweden', in Arthur of the North: Histories, Emotions, and Imaginations, ed. Bjørn Bandlien, Stefka G. Eriksen and Sif Rikhardsdottir, special issue of Scandinavian Studies 87.1 (2015), 62-73.

Loomis, Roger Sherman, Arthurian Tradition and Chrétien de Troyes. New York: Columbia University Press, 1949. 
Lorenz, Christine, 'Ór franzeisu í norronu': The Transmission of Chrétien de Troyes' Arthurian Romances to Old Norse Literature. PhD dissertation, Durham University, 2007.

Luttrell, Claude, 'The Heart's Mirror in Cligès', in Arthurian Literature 13, ed. James P. Carley and Felicity Riddy. Cambridge, UK: D.S. Brewer, 1995, 1-18.

Lutz, Catherine A., Unnatural Emotions. Chicago/London: The University of Chicago Press, 1988.

Lutz, Catherine A. and Geoffrey M. White, 'Anthropology of Emotions', Annual Review of Anthropology 15.1 (1986), 405-36.

Lynch, Andrew, 'Making Joy/Seeing Sorrow: Emotional and Affective Resources in the Stanzaic Morte Arthur', Arthuriana 28.3 (2018), 33-50. 'Positive Emotion in Arthurian Romance: Introduction', Journal of the International Arthurian Society 4.1 (2016), 53-57.

— Arthurian Society 4.1 (2016), 53-57.

MacKenzie, Colin Peter, 'Old Norse-Icelandic Personhood Constructs', in Heart- and Soullike Constructs across Languages, Cultures and Epochs, ed. Bert Peeters. New York: Routledge, 2019, 116-45.

—, Vernacular Psychologies in Old Norse-Icelandic and Old English. PhD dissertation, University of Glasgow, 2014.

Maddern, Philippa, Joanne McEwan, and Anne M. Scott, eds, Performing Emotions in Early Europe. Early European Research 11. Turnhout: Brepols, 2018.

de Man, Paul, "Conclusions": Walter Benjamin's "Task of the Translator", in The Resistance to Theory, ed. Paul de Man. Theory and History of Literature 33. Minneapolis: University of Minnesota Press, 1986, 73-105. 
Marti, Suzanne, 'Translation or Adaptation? Parcevals saga as a Result of Cultural Transformation', Arthuriana 22.1 (2012), 39-52.

McCash, June Hall, 'Chrétien's Patrons', in A Companion to Chrétien de Troyes, ed. Norris Lacy and Joan Tasker Grimbert. Cambridge, UK: D.S. Brewer, 2005, 15-25. McConeghy, Patrick, 'Women's Speech and Silence in Hartmann von Aue's Erec,' Publications of the Modern Language Association of America 102.5 (1987), 772-83. McDougall, William, The Group Mind. New York: Putnam, 1920.

McFarland, Timothy and Silvia Ranawake, eds., Hartmann von Aue: Changing Perspectives. London Hartmann Symposium 1985. Göppingen: Kümmerle, 1988.

McGrath, Robert L., 'A Newly Discovered Illustrated Manuscript of Chrétien de Troyes’s Yvain and Lancelot in the Princeton University Library', Speculum 38 (1963), 583-94. Mehl, Dieter, The Middle English Romances of the Thirteenth and Fourteenth Centuries (Routledge Revivals). London: Routledge, 2010 [first published 1968].

Mertens, Volker, Die Eufemiavisor als Zeugnis deutsch-skandinavischer Kulturkontakte', Jahrbuch der Oswald von Wolkenstein Gesellschaft 16 (2006/2007), 159-78.

— Laudine: Soziale Problematik im Iwein Hartmanns von Aue. Beihefte zur Zeitschrift für deutsche Philologie 3. Berlin: Schmidt, 1978.

Meyer, Evelyn, 'Manuscript versus Edition: The Multiple Endings of Yvain/Iwein/Ywayne and their Gender Implications,' Amsterdamer Beiträge zur älteren Germanistik 67 (2011), 97-141.

Micha, Alexandre, La tradition manuscrite des romans de Chrétien de Troyes. Geneva: Droz, 1939.

Miller, William Ian, 'Emotions and the Sagas' in From Sagas to Society: Comparative Approaches to Early Iceland, ed. Gísli Pálsson. Middlesex: Hisarlik Press, 1992, 89_ 110. 
Mills, Maldwyn et al., 'Chivalric Romance', in The Arthur of the English: The Arthurian Legend in Medieval English Life and Literature, ed. W. R. J. Barron. Cardiff: University of Wales Press, 2001, 113-84.

Moore, John C., “"Courtly Love”: A Problem of Terminology', Journal of the History of Ideas 40 (1979), 621-32.

Morgans, Lowri, 'Peredur Son of Efrawg: The Question of Translation and/or Adaptation', in Handbook of Arthurian Romance, ed. Leah Tether and Johnny McFadyen. Berlin: De Gruyter, 2017, 403-14.

Möller, Roland, 'Untersuchungen an der Wandmalereien des Iwein-epos Hartmanns von Aue im Hessenhof in Schmalkalden', in Zur Kunst des 13. Jahrhunderts in Mitteldeutschland, ed. Hans-Joachim Krause, Festschrift für Ernst Schubert/Sachsen und Anhalt, Jarbuch der historischen Kommission für Sachsen-Anhalt 19. Weimar, 1997, 389-453.

Munson, Marcella, “'Cil qui l'escrist”: Narrative Authority and Intervention in Chrétien de Troyes's Yvain', Paroles gelées 12.1 (1994), 27-45.

Murdoch, Brian, 'Hartmann's Legends and the Bible', in A Companion to the Works of Hartmann von Aue. Rochester, NY: Boydell \& Brewer/Camden House, 2005, 141-60.

Neubuhr, Elfriede, Bibliographie zu Hartmann von Aue. Berlin: Schmidt, 1977.

Newhauser, Richard G., ed., A Cultural History of the Senses in the Middle Ages. London/New Delhi/ New York/Sydney: Bloomsbury, 2014.

Nichols, Stephen, 'Introduction: Philology in a Manuscript Culture', Speculum 65.1 (1990), $1-10$.

—_, 'Why Material Philology? Some Thoughts', Zeitschrift für deutsche Philologie 116 (1997), 10-30. 
Nichols, Stephen, Andreas Kablitz and Alison Calhoun, eds, Rethinking the Medieval Senses: Heritage, Fascinations, Frames. Baltimore: John Hopkins University Press, 2008.

Nussbaum, Martha, Upheavals of Thought: The Intelligence of Emotions. Cambridge, UK: Cambridge University Press, 2001.

Oatley, Keith and Philip N. Johnson-Laird, 'The Communicative Theory of Emotions:

Empirical Tests, Mental Models, and Implications for Social Interaction', in Striving and Feeling: Interactions among Goals, Affect, and Self-Regulation, ed. Leonard L. Martin and Abraham Tesser. Mahwah NJ: Erlbaum, 1996, 363-80.

Oh, Erika, Aufbau und Einzelszenen in Hartmanns von Aue höfischen Epen Erec und Iwein. PhD dissertation, University of Hamburg, 1972.

Ollier, Marie-Louise, 'The Author in the Text: The Prologues of Chrétien de Troyes', Yale French Studies 51 (1974), 26-41.

Ordbog over det norrøne prosasprog/A Dictionary of Old Norse Prose. Copenhagen: Arnamagnæan Commission/ Arnamagnæanske commission, 1983-. Retrieved from https://onp.ku.dk/.

Ortony, Andrew and Terence J. Turner, 'What's Basic about Basic Emotions?', Psychological Review 97.3 (1990), 315-31.

Óskarsson, Pórir, 'Rhetoric and Style', in A Companion to Old Norse-Icelandic Literature and Culture, ed. Rory McTurk. Oxford: Blackwell Publishing, 2005, 354-71.

Ovens, Michael, 'Violence and Transgression in Chrétien's Yvain', Parergon 32.1 (2015), $53-76$.

Panksepp, Jaak, Affective Neuroscience: The Foundations of Human and Animal Emotions. New York/Oxford: Oxford University Press, 1998.

Parker, Andrew and Eve Kosofsky Sedgwick, eds, Performativity and Performance. New York/London: Routledge, 1995. 
Parkes, Malcolm B., Pause and Effect: An Introduction to the History of Punctuation in the West. Berkeley: University of California Press, 1992.

Parrott, W. Gerrod, 'Feeling, Functions, and the Place of Negative Emotions in a Happy Life', in The Positive Side of Negative Emotions, ed. W. Gerrod Parrott. New York: Guildford Press, 2014, 273-97.

Peil, Dietmar, Die Gebärde bei Chrétien, Hartmann und Wolfram. Medium Aevum: Philologische Studien 28. München: Wilhelm Fink, 1975.

Pettigrove, Glenn and Nigel Parson, 'Shame: A Case Study of Collective Emotion', Social Theory and Practice 38 (2012), 1-27.

Pincikowski, Scott E., 'The Body in Pain in the Works of Hartmann von Aue', in $A$ Companion to the Works of Hartmann von Aue. Rochester, NY: Boydell \& Brewer/Camden House, 2005, 105-24.

Plamper, Jan, The History of Emotion: An Introduction, trans. Keith Tribe. Oxford: Oxford University Press, 2015.

Plutchik, Robert, 'Nature of Emotions', American Scientist 89.4 (2002), 344-50.

Porter, Edel and Teodoro Manrique Antón, 'Flushing in Anger, Blushing in Shame: Somatic Markers in Old Norse Emotional Expressions', Cognitive Linguistic Studies 2.1 (2015), 24-49.

Pratt, Karen, 'Adapting Enide: Chrétien, Hartmann and the Female Reader', in Chrétien de Troyes and the German Middle Ages, ed. Martin H. Jones and Roy E. Wisbey. Arthurian Studies 26. Cambridge, UK: D.S. Brewer, 1993, 67-85.

Putter, Ad, 'The Twelfth-Century Arthur', in The Cambridge Companion to the Arthurian Legend, ed. Elizabeth Archibald and Ad Putter. Cambridge, UK/New York: Cambridge University Press, 2009, 36-52. 
Quast, Bruno, “Getriuwiu wandelunge": "Ehe” und "Minne” in Hartmanns Erec', Zeitschrift für deutsches Altertum und deutsche Literatur 122 (1993), 162-80.

Ranawake, Silvia, 'Erecs verligen and the Sin of Sloth', in Hartmann von Aue: Changing Perspectives, ed. Timothy McFarland and Silvia Ranawake. Göppingen: Kümmerle, 1985, 93-116.

Reddy, William, ‘Against Constructionism: The Historical Ethnography of Emotions', Current Anthropology 38.3 (1997), 327-51.

—, The Making of Romantic Love: Longing and Sexuality in Europe, South Asia, and Japan, 900-1200 CE. Chicago: University of Chicago Press, 2012.

- The Navigation of Feeling: A Framework for the History of Emotions. Cambridge, UK: Cambridge University Press, 2001.

Rikhardsdottir, Sif, 'Chronology, Anachronism and Translatio Imperii', in Handbook of Arthurian Romance, ed. Leah Tether and Johnny McFadyen. Berlin: De Gruyter, 2017, 135-50.

— Emotion in Old Norse Literature: Translations, Voices, Contexts. Cambridge, UK: D.S Brewer, 2017.

—, Medieval Translations and Cultural Discourse: The Movement of Texts in England, France and Scandinavia. Cambridge, UK: D.S. Brewer, 2012.

— , 'Translating Emotion in Yvain and Ívens saga', in Emotions in Medieval Arthurian Literature: Body, Mind, Voice, ed. Frank Brandsma, Caroline Larrington and Corinne Saunders. Arthurian Studies 83. Cambridge, UK: D.S. Brewer, 2015, 161-79.

Rikhardsdottir, Sif and Stefka G. Eriksen, 'État present: Arthurian Literature in the North', Journal of the International Arthurian Society 1.1 (2013), 3-28.

Roberts, Brynley F., Studies on Middle Welsh Literature. New York: Edwin Mellen Press, 1992. 
Robertson Jr, Durant W., 'The Concept of Courtly Love as an Impediment to the Understanding of Medieval Texts, in The Meaning of Courtly Love, ed. Francis X. Newman. New York: State University of New York Press, 1968, 1-18.

Robinson, Jenefer, Deeper than Reason: Emotions and its Role in Literature, Music, and Art. Oxford: Clarendon Press, 2005.

Rosenwein, Barbara H., ed., Anger's Past: The Social Uses of an Emotion in the Middle Ages. Ithaca/London: Cornell University Press, 1998.

- Generations of Feeling: A History of Emotions 600-1700. Cambridge, UK: Cambridge University Press, 2016.

— 42.

—_, 'Writing Without Fear about Early Medieval Emotions', Early Medieval Europe 10.2 (2001), 229-34.

Rossi, Luciano, 'Chrétien de Troyes e i trovatori: Tristan, Linhaura, Carestia', Vox Romanica 46 (1987), 26-62.

Rushing, James A., Jr., Images of Adventure: Ywain in the Visual Arts. Philadelphia, PA: University of Pennsylvania Press, 1995.

Rychner, Jean, La chanson de geste: Essai sur l'art épique des jongleurs. Geneva: Droz, 1995.

Salmela, Miko, 'Shared Emotions', Philosophical Explorations: An International Journal for the Philosophy of Mind and Action 15.2 (2012), 33-46.

Saunders, Corinne, 'Mind, Body and Affect in Medieval English Arthurian Romance', in Emotions in Medieval Arthurian Literature: Body, Mind, Voice, ed. Frank Brandsma, Caroline Larrington and Corinne Saunders. Arthurian Studies 83. Cambridge, UK: D.S. Brewer, 2015, 31-46. 
Sävborg, Daniel, Sagan om kärleken: Erotik, känslor och berättarkonst I norrön litteratur, Acta Universitatis Upsaliensis. Historia litterarum 27. Uppsala: Uppsala universitet, 2007.

_ ' 'The Sagas and Courtly Love', in The Viking Age: Ireland and the West. Proceedings of the Fifteenth Viking Congress, ed. John Sheehan and Donnchadh Ó Corráin. Dublin: Four Courts Press, 2010, 361-68.

Schach, Paul, 'Some Observations on the Translations of Brother Robert', in Les relations littéraires franco-scandinaves au Moyen Âge, Actes du Colloque de Liège. Paris: Les Belles Lettres, 1975, 117-35.

Scheer, Monique, 'Feeling Faith: The Cultural Practice of Religious Emotions in NineteenthCentury German Methodism,' in Out of the Tower: Essays on Culture and Everyday Life, ed. Monique Scheer et al. Tübingen: TVV, 2013, 217-47.

Scheff, Thomas J. and Suzanne M. Retzinger, Emotions and Violence: Shame and Rage in Destructive Conflicts. Lexington, MA: Lexington Books, 1991.

Scherer, Klaus R., 'What are Emotions? And How can They be Measured?' Social Science Information 44 (2005), 695-729.

Scherer, Klaus R., Angela Schorr, Tom Johnstone, eds., Appraisal Processes in Emotion: Theory, Methods, Research. New York: Oxford University Press, 2001.

von Scheve, Christian and Mikko Salmela, eds, Collective Emotions: Perspectives from Psychology, Philosophy, and Sociology. Oxford: Oxford University Press, 2014. Schleich, Gustav, Über das Verhältnis der mittelenglischen Romanze Ywain and Gawain zu ihrer altfranzösischen Quelle, Wissenschaftliche Beilage zum Programm des AndreasRealgymnasiums zu Berlin. Berlin: R. Gaertner, 1889.

Schlusemann, Rita, 'The Late-Medieval German Reception of Dutch Arthurian Literature in Heidelberg and Blankenheim', in King Arthur in the Medieval Low Countries, ed. 
Geert H.M. Claassens and David F. Johnson. Leuven: Leuven University Press, 2000, $97-111$.

Schmitt, Jean-Claude, La raison des gestes dans l'Occident médiéval. Paris: Gallimard, 1990.

- The Rationale of Gestures in the West, in A Cultural History of Gesture from Antiquity to the Present Day, ed. Jan Bremmer and Herman Roodenburg. Cambridge, UK: Polity Press, 1991, 59-70.

Schnell, Rüdiger, 'Erzähler - Protagonist - Rezipient im Mittelalter, oder: Was ist der Gegenstand der literaturwissenschaftlichen Emotionsforschung', Internationales Archiv für Sozialgeschichte der deutschen Literatur 33 (2008), 1-50.

Schröder, Werner, Laudines Kniefall und der Schluß von Hartmanns Iwein. Stuttgart: Steiner, 1997.

Schultz-Balluff, Simone, Wissenswelt 'Triuwe': Kollakationen - Semantisierung Konzeptualisierung. Heidelberg: Universitätsverlag Winter, 2018.

Schweikle, Günther, ed., Dichter über Dichter im mittelhochdeutscher Literatur, Deutsche Texte 12. Tübingen: Niemeyer, 1970.

Schweitzer, Edward, 'Pattern and Theme in Chrétien's Yvain', Traditio 30 (1974), 145-89. von See, Klaus, 'Das Herz in Edda und Skaldendichtung', Skandinavistik 8 (1978), 16-26, reprinted in Klaus von See, Edda, Saga, Skaldendichtung: Aufsätze zur scandinavischen Literatur des Mittelalter. Heidelberg: Carl Winter, 1981.

Seidel, Katharina, Textvarianz und Textstabilität: Studien zur Transmission der Ívens saga, Erex saga und Parcevals saga. Beiträge zur nordischen Philologie 56. Tübingen: A. Francke Verlag, 2014.

Smits, Kathryn, 'Enite als christliche Ehefrau,' in Interpretation und Edition deutscher Texte des Mittelalters: Festschrift für John Asher, ed. Kathryn Smits, Werner Besch and Victor Lange. Berlin: Erich Schmidt Verlag, 1981, 13-25. 
Springer, Otto, 'The Style of the Old Icelandic Family Sagas', Journal of English and Germanic Philology 38.1 (1939), 107-28.

Stahuljak, Zrinka, ‘An Epistemology of Tension', The Translator 10.1 (2004), 33-57.

— , 'Medieval Fixers: Politics of Interpreting in Western Historiography', in Rethinking Medieval Translation, ed. Emma Campbell and Robert Mills. Cambridge, UK: D.S. Brewer, 2012, 147-63.

Stahuljak, Zrinka et al., Thinking Through Chrétien de Troyes. Gallica 19. Cambridge: D.S. Brewer, 2011.

Starkey, Kathryn, 'Brunhild's Smile: Emotion and the Politics of Gender in the Nibelungenlied', in Codierungen von Emotionen im Mittelalter/Emotions and Sensibilities in the Middle Ages, ed. Stephen C. Jaeger and Ingrid Kasten. Berlin: De Gruyter, 2003, 159-73.

— , 'Performative Emotion and the Politics of Gender in the Nibelungenlied', in Women and Medieval Epic: Gender, Genre and the Limits of Epic Masculinity, ed. Sara S. Poor and Jane K. Schulman. New York: Palgrave Macmillan, 2007, 253-71.

Starkey, Kathryn and Horst Wenzel, 'The Visuality of German Courtly Literature', Oxford German Studies 37.2 (2008), 130-59.

Sterba, Wendy, 'The Question of Enite's Transgression: Female Voice and Male Gaze as Determining Factors in Hartmann's Erec', in Women as Protagonists and Poets in the German Middle Ages, ed. Albrecht Classen. Göppinger Arbeiten zur Germanistik 528. Göppingen: Kümmerle, 1991, 57-68.

Sterling-Hellenbrand, Alexandra, The Topographies of Gender in Middle High German Arthurian Romance. New York/London: Routledge, 2001.

Stewart, Dana E., The Arrow of Love: Optics, Gender and Subjectivity in Medieval Love Poetry. London: Associated University Presses, 2003. 
Stoll, Jessica, 'The Medieval French Lexicon of Translation', Neophilologus 99 (2015), 191207.

Stuip, R.E.V and C. Vellekoop, eds, Emoties in de Middeleeuwen. Verloren: Hilversum, 1998.

Sullivan, Joseph M., 'Arthur of the Northeast: The Old Swedisch Herr Ivan Redraws the King Arthur of Chrétien's Yvain', in Arthur of the North: Histories, Emotions, and Imaginations, ed. Bjørn Bandlien, Stefka G. Eriksen and Sif Rikhardsdottir, special issue of Scandinavian Studies 87.1 (2015), 33-61.

__ ' 'Laudine: The Old Swedish Herr Ivan Adapts a Character from Chrétien's Yvain', Yearbook of the Society for Medieval German Studies 1 (2009), 50-75.

_ Chrétien's Yvain and Hartmann's Iwein,' Neophilologus 85 (2001), 335-54.

Szkilnik, Michelle, 'Medieval Translations and Adaptations of Chrétien's Works', in $A$ Companion to Chrétien de Troyes, ed. Norris Lacy and Joan Tasker Grimbert. Cambridge, UK: D.S. Brewer, 2005, 202-13.

Tarde, Gabriel, Les lois de l'imitation: Étude sociologique. Paris: Félix Alcan, 1890.

- The Laws of Imitation, trans. Elsie Clews Parsons. New York: Henry Holt and Company, 1903.

Taylor, Jane H.M., 'Rewriting, Translation, Continuation and Adaptation', in Handbook of Arthurian Romance, ed. Leah Tether and Johnny McFadyen. Berlin: De Gruyter, 2017, 167-82.

Tether, Leah and Johnny McFadyen, eds, 'Introduction: King Arthur's Court in Medieval European Literature', in Handbook of Arthurian Romance. Berlin: De Gruyter, 2017, $1-10$. 
Thomson, R.L., 'Owain: Chwedl Iarlles y Ffynnon', in The Arthur of the Welsh: The Arthurian Legend in Medieval Welsh Literature, ed. Rachel Bromwich, A.O.H. Jarman and Brynley F. Roberts. Cardiff: University of Wales Press, 1991, 159-69.

Tobin, Frank, 'Hartmann's Erec: The Perils of Young Love', Seminar 14 (1978), 1-14.

Tomkin, Silvan, 'Script Theory: Differential Magnification of Affects', in Nebraska Symposium on Motivation 1978, 26, ed. Herbert E. Howe and Richard A. Dienstbier. Lincoln: University of Nebraska Press, 1979, 201-36.

Tonkin, Humphrey and Maria Esposito Frank, eds, Translator as Mediator of Cultures. Amsterdam: John Benjamins Publishing Company, 2010.

Topsfield, Leslie, Chrétien de Troyes: A Study of the Arthurian Romances. Cambridge, UK: Cambridge University Press, 1981.

Turner, Edith, Communitas: The Anthropology of Collective Joy. Basingstoke: Palgrave, 2012.

Tymoczko, Maria, 'Ideology and the Position of the Translator: In what Sense is a Translator “in between”?', in Apropos of Ideology: Translation Studies on Ideology - Ideologies in Translation Studies, ed. María Calzada Pérez. New York: Routledge, 2014, 181201.

Venuti, Lawrence, The Translator's Invisibility: A History of Translation. London/New York: Routledge, 1995

Vitz, Evelyn Birge, Orality and Performance in Early French Romance. Woodbridge: Brewer, 1999.

Vondenhoff, Chloé, ‘Cuer me rendés... ’: The Emotional Involvement of the Contemporary Audience in the Yvain-corpus, MA thesis 2013, Utrecht University.

—_, 'Een leeuw met menselijke trekjes', Madoc 29.1 (2015), 2-10. 
_ ' 'Matter(s) of the Heart in Yvain and Ívens saga', in The Feeling Heart in Medieval and Early Modern Europe: Meaning, Embodiment and Making, ed. Katie Barclay and Bronwyn Reddan. Studies in Medieval and Modern Culture 67, MIP. Berlin/Boston: De Gruyter, 2019, 43-58.

— 'The Performative Function of the Socialised Body: Falling to One's Knees in Hartmann's Iwein and Erec', Arthuriana 29.4 (2019), 8-27.

Voss, Rudolf, Die Artusepik Hartmanns von Aue: Untersuchungen zum Wirklichkeitsbegriff und zur Ästhetik eines literarischen Genres im Kräftefeld von soziokulturellen Normen und christlicher Antropologie. Cologne: Böhlau, 1983.

Wack, Mary Frances, Lovesickness in the Middle Ages: The Viaticum and Its Commentaries. Philadelphia, PA: University of Pennsylvania Press, 1990.

Wapnewski, Peter, Hartmann von Aue. Sammlung Metzler Realien zur Literatur 17. Stuttgart: J.B. Metzler, 1979.

Webb, Heather, The Medieval Heart. New Haven: Yale University Press, 2010.

Wetherell, Margaret, Affect and Emotion: A New Social Science Understanding. London: Sage Publications Ltd, 2012.

Williams, Carol J., 'Two Views of the Feeling Heart in Troubadour Song', in The Feeling Heart in Medieval and Early Modern Europe: Meaning, Embodiment and Making, ed. Katie Barclay and Bronwyn Reddan. Studies in Medieval and Modern Culture 67, MIP. Berlin/Boston: De Gruyter, 2019, 59-78.

Willson, H.B., “"Triuwe” and “Untriuwe” in Hartmann's Erec', German Quarterly 43 (1970), 5-23.

Wolf, Kirsten, 'Somatic Semiotics: Emotion and the Human Face in the Sagas and Pattir of Icelanders', Traditio 69 (2014), 125-45. 
Wolff, Ludwig, 'Die Iwein-Handschriften in ihrem Verhältnis zueinander', in Festschrift Helmut de Boor. Tübingen: Niemeyer, 1966, 111-35.

Woolgar, Chris, 'The Social Life of the Senses: Experiencing the Self, Others, and Environments', in A Cultural History of the Senses in the Middle Ages, ed. Richard G. Newhauser. London/New Delhi/New York/Sydney: Bloomsbury, 2014, 23-44.

Yates, Frances A., The Art of Memory. Chicago: University of Chicago Press, 1966.

Zaddy, Zara Patricia, 'The Structure of Chrétien's Yvain', The Modern Language Review 65.3 (1970), 523-40.

Zumthor, Paul, Essai de poétique médiévale/Toward a Medieval Poetics, trans. Philip Bennett. Minneapolis: University of Minnesota Press, 1992 [first published 1972]. Porleifsdóttir, Hanna Steinunn, 'Dialogue in the Icelandic Copies of Ívens saga', in Übersetzen im skandinavischen Mittelalter, ed. Vera Johanterwage and Stefanie Würth. Vienna: Verlag Fassbaender, 2007, 167-76. 


\section{APPENDIX}

\section{Synopsis}

The story of the Knight with the Lion, as we find it in all the versions under examination in this study, tells about the social rising and falling of the knight Yvain (MHG Îwein; ON Íven; OS Ivan; ME Ywain) and narrates the adventurous road towards his societal reintegration, both as a knight and a lover. The tensions between armes and armours underlie the knight's brittle social status, as the story seeks to harmonise the conflicting claims of knighthood and love. In addition to chivalry and love, the story centres on themes such as friendship, loyalty, adventure and the marvellous.

With its characteristic Doppelwegstruktur (two adventure cycles), the story of the Knight with the Lion follows an episodic structure. ${ }^{437}$ Its bipartite arrangement divides the storyline into two cycles. ${ }^{438}$ The first adventure sequence, often referred to as the preliminary

\footnotetext{
${ }^{437}$ The Doppelwegstruktur is a structural model that is typically assigned to Hartmann von Aue's Iwein and Erec, but is also described for their French sources as a 'bipartite structure' (for studies see footnote 438). The term is used here not to describe a uniform structural form as the Doppelweg-model varies among literary theorists, but refers to the double adventure cycle along which the Yvain-story is structured. For more information see Hans Fromm, 'Doppelweg', in Arbeiten zur deutschen Literatur des Mittelalters, ed. Hans Fromm (Tübingen: Max Niemeyer Verlag, 1989) 122-36; Hugo Kuhn, Dichtung and Welt im Mittelalter (Stuttgart: Metzler, 1969), part 2, 62-69; Walter Haug, 'Die Symbolstruktur des höfischen Epos und ihre Auflösung bei Wolfram von Eschenbach', Deutsche Vierteljahrsschrift für Literaturwissenschaft und Geistesgeschichte 45 (1971), 668-705.

${ }^{438}$ As first suggested by Retro Bezzola and Mario Roques (Bezzola, Le Sens du l'aventure et de l'amour, Paris: La Jeune Parque, 1947, 81-82; Roques, ed., Le chevalier au lion (Yvain), Paris: Classiques Français du Moyen Âge, 1960, xi). I follow Bezzola and Roques in outlining a bipartite structure for the Yvain-story. Opinion is however divided over the story's structure. Thomas Bertram Wallace Read and Jean Frappier have argued for a tripartite structure (See Reid's introductory notes to Wendelin Foerster's critical text of Yvain, Le chevalier au lion, Manchester: Manchester University Press, 1942, xi; Frappier, Le roman breton: Yvain ou le chevalier au
} 
cycle, sets the stage and introduces the hero. Within the first cycle, Arthur's court plays an important role as the starting point for adventure. Already in the first cycle, the knight protagonist can be found to meet the challenge set to him. The storyline, however, follows a binary structure: what was seemingly obtained without too much effort becomes a personal challenge, as it is lost again, typically through carelessness on the knight's part. Thus in the Yvain-story, the knight becomes the Lord of the Fountain and wins himself a bride, only to lose his lady (and her title) again when he choses knighthood over love. This serves as an incentive for the second adventure cycle. It typically involves a period of alienation, as the knight abandons civilisation. The subsequent process of social rehabilitation centres on explicating the hero's valour and chivalric prowess through various independent adventures. Within the story's bipartite structure, the adventures of Yvain can be subdivided in the following episodes: ${ }^{439}$

I. As literary tradition dictates, the story of the knight Yvain opens at Arthur's court on a feast day, this time Pentecost. The opening scene sets the stage for the glorification of chivalric ideals and values, while simultaneously critically observing the instabilities of the court: Arthur is held up by his queen in bed whilst a group of knights wait outside of their bedroom door, meanwhile seneschal Keu (Key; Kæi; Kæyæ; Kay) is busy mocking his fellow knights, and it is left to the queen to intervene. The narrative focus, however, goes out to Calogrenant (Kalogreant; Kalebrant; Kalegrevanz; Colgrevance) who is about to begin a tale, not of honour but of disgrace. Thus unfolds the adventure of the Fountain. The knight relates how some years ago, he set out in search of a testing adventure in the forest of Brocéliande

lion, Paris: Centre de documentation universitaire, 1952, 8-9). They suggest that the relationship crisis between Yvain and his lady starts a new section that functions to bridge part one and two.

${ }^{439}$ This division is my own, but for the most part follows Zara Patricia Zaddy's example, with the exception of her subdivisions within episodes (a,b,c), see, Zaddy, 'The Structure of Chrétien's Yvain', The Modern Language Review 65.3 (1970), 523-40. 
(Brezziljân; / / ;/) where he was challenged and shamefully defeated by the defender of the Fountain (Esclados; Ascalon; Sodal; Vadein; Salados). On hearing about Calogrenant's defeat, Yvain vows to avenge his cousin's shame. Undaunted by Keu's mockery, he sets off the next morning to undertake the adventure of the Fountain alone.

II. Like his cousin before him, Yvain meets a vavasour and his beautiful daughter and has a strange encounter with a grotesque herdsman before arriving at the Fountain. He too takes water from the spring and pours it over the emerald stone, thereby provoking a terrible storm. Not a second after the storm abates, the Knight of the Fountain comes charging at him with great speed. Unlike Calogrenant, Yvain manages to defeat his assailant in a bitter duel and chases the dying knight back to his castle. As Yvain enters the gateway, the portcullis falls, trapping him between two gates. Help arrives in the unexpected form of the quickthinking maid, Lunete (Lûnet; Lúneta; Luneta; Lunet), who owes the knight for a past favour and decides to hide Yvain from Esclados' grieving household. Enraged, they are upending the castle in search of their lord's killer, meaning to capture him in some renditions of the story, going around with murderous intent in others. Although they pass Yvain numerous times, he is hidden from their sight with an invisibility ring. As the party prepares for their lord's funeral, Yvain falls in love at the sight of Esclados' widow, La dame de Landuc or Laudine (Laudîne; 'the lady'; 'the lady'; Alundyne). With the help of Lunete, he is able to persuade Laudine to marry him once he has revealed himself to be the knight who killed her husband, who, surely, the shrewd maiden argues, is the better knight and will prove to be a better defender of the Fountain and her lands.

III. Yvain's new guardianship is tested soon after by Keu, who arrives with Arthur's party, intending to lay claim to the land. The story, however, takes a comical turn as Yvain throws boastful Keu from his saddle and he somersaults to the ground. The party is invited back to the castle and they all partake in joyous festivities. The first adventure cycle is about 
to come to an end with Yvain having avenged his cousin's dishonour, having gained personal glory as a knight, and with the obtaining of a bride and a lordship. When Arthur's party prepares to leave, however, Gauvain (Gâwein; Valven; Gavian; Gawain) warns of the danger in languishing in the thralls of love for too long and persuades Yvain to accompany him on a sequence of tournaments. Laudine gives in to this request, but stipulates that he must return within one year. When the knight, however, fails to honour this term, Lunete seeks him out to return to her lady her ring and her love. Not only does Yvain lose his beloved wife, but he also loses face — and even his name — as he is publically denounced for his transgression against love before all of court.

IV. Mad with grief, he disappears into the forest to live like a nameless wild-man. One day, Yvain is found by a passing lady and cured from his madness by one of her maidens. Repaying the favour, he helps the Lady of Noroison (frouwe von Nârisôn; 'the lady'; 'the lady'; 'the lady') to defeat her enemy, Count Aliers (Earl Aleus; Earl Arlans; Count Âliern; Syr Alers), who has declared war upon the town. This episode marks the beginning of Yvain's gradual return to knighthood since from this point onwards the narrative describes a series of interlacing adventures, which can be seen as a test of Yvain's chivalry. Lending Yvain his new identity as a knight is a lion, whose life he saves from a fiery death by a venomous dragon. Afterward, the lion does not leave Yvain's side and becomes his constant companion.

V. Together they set out to rescue Lunete, who has been falsely accused of scheming against her lady and is to be burned at the stake the next day, only to come across another adventure that is to take place the next morning. Seeking shelter for the night, they arrive at a strongly fortified castle that has been plagued by a giant named Harpin de la Montaingne (Harpîn; Fjallsharfir; Fiælskarper; Harpyns of Mowntain) for the past weeks. The loathsome giant has threatened to renew his attack the next day. Taking pity on the chatelain's family, 
who turn out to be Gauvain's relatives, Yvain promises to come to their aid on the condition that he will be able to leave before the hour of prime. The episode recalls Yvain's earlier difficulty with holding deadlines when he forsook his promise to Laudine to return at her side after one year and evokes a sense of foreboding. However, after a long and fierce fight that comes to an end with the death of the giant, Yvain arrives just in time to defend Lunete's honour against her accusers. Having learned from his past mistake, these interlinked adventures mark a process of growth in the knight that is symbolized by his new identity as the Knight with the Lion. Unaware of his true identity, Laudine honours him as the victor and Lunete is freed.

VI. In the two final, interlaced adventures, Yvain particularly proves himself as the champion of defenceless women. The knight is sought out by the younger daughter of the Lord of Noire Espine, who requires his help in an inheritance dispute. On his way to Arthur's court to defend this maiden, who is being deprived of her share of the inheritance by her older sister (the wrongdoer varies between the versions), he comes upon the Castle of Infinite Misfortune, where Yvain fights two demons and rescues three hundred abused maidens from having to work silk night and day. The adventure cycle comes to a climax as Yvain rushes back to champion the aggrieved sister's cause and finds himself opposite a most excellent and stout knight, whom he does not recognise to be his good friend Gauvain, championing for the elder sister. The knights continue to engage in a long and fierce fight since the knights are so evenly matched that neither of them breaks ground on the other. When the two friends, however, realise that they are fighting each other, they are reconciled, favouring the younger sister in the dispute.

VII. Still grieving over the loss of Laudine, Yvain returns to the fountain in the hope of reuniting with his wife. With a clever ruse, Lunete tricks her lady into swearing an oath to do everything in her power to help the Knight with the Lion win back the favour of his lady. 
In the slow disclosure of the Knight with the Lion's true identity the story is working towards its dénouement, as, with a slight force of hand by Lunete, the knight and his lady are finally reconciled and Yvain's status and reputation is restored.

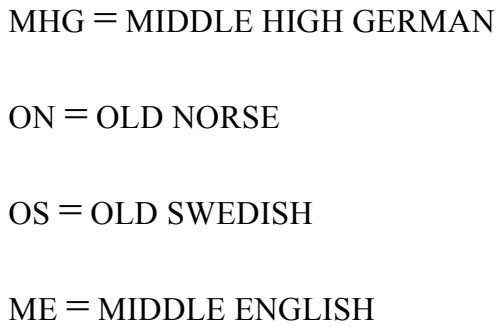

\section{Images}

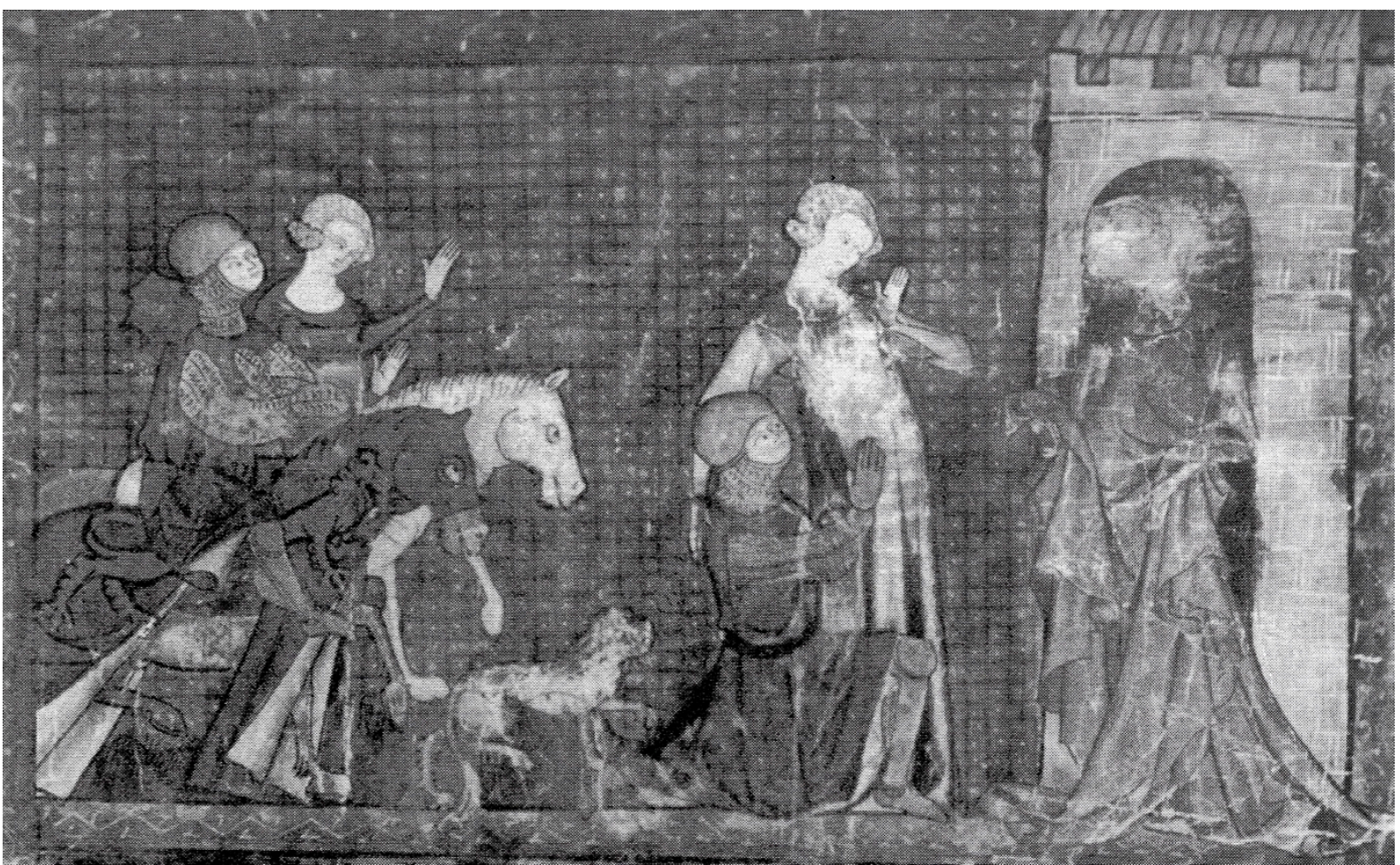

Image 1. Yvain and Lunete, accompanied by the lion, ride up to the castle of Landuc and Yvain kneels before Laudine. Paris, Bibliothèque Nationale, fr. 1433, fol. 69v. From: James A. Rushing, Images of Adventure: Ywain in the Visual Arts (Philadelphia, University of Pennsylvania Press, 1995), 177. 


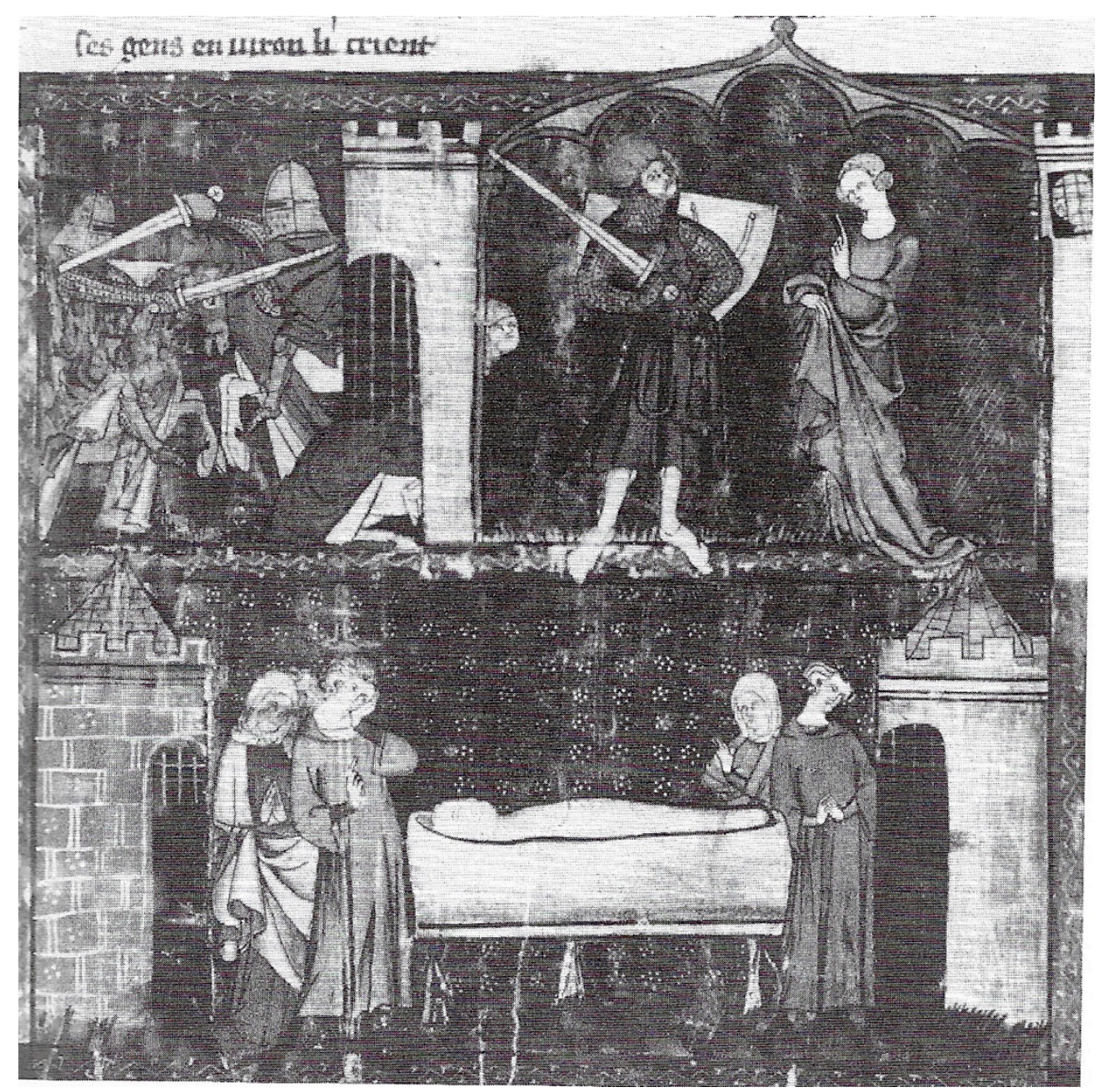

Image 2. The entire sequence of events: Yvain's defeat of Esclados, Yvain is trapped in the castle, and the death of Esclados. Paris, Bibliothèque Nationale, fr. 1433, fol. 69v. From: James A. Rushing, Images of Adventure: Ywain in the Visual Arts (Philadelphia, University of Pennsylvania Press, 1995), 177.

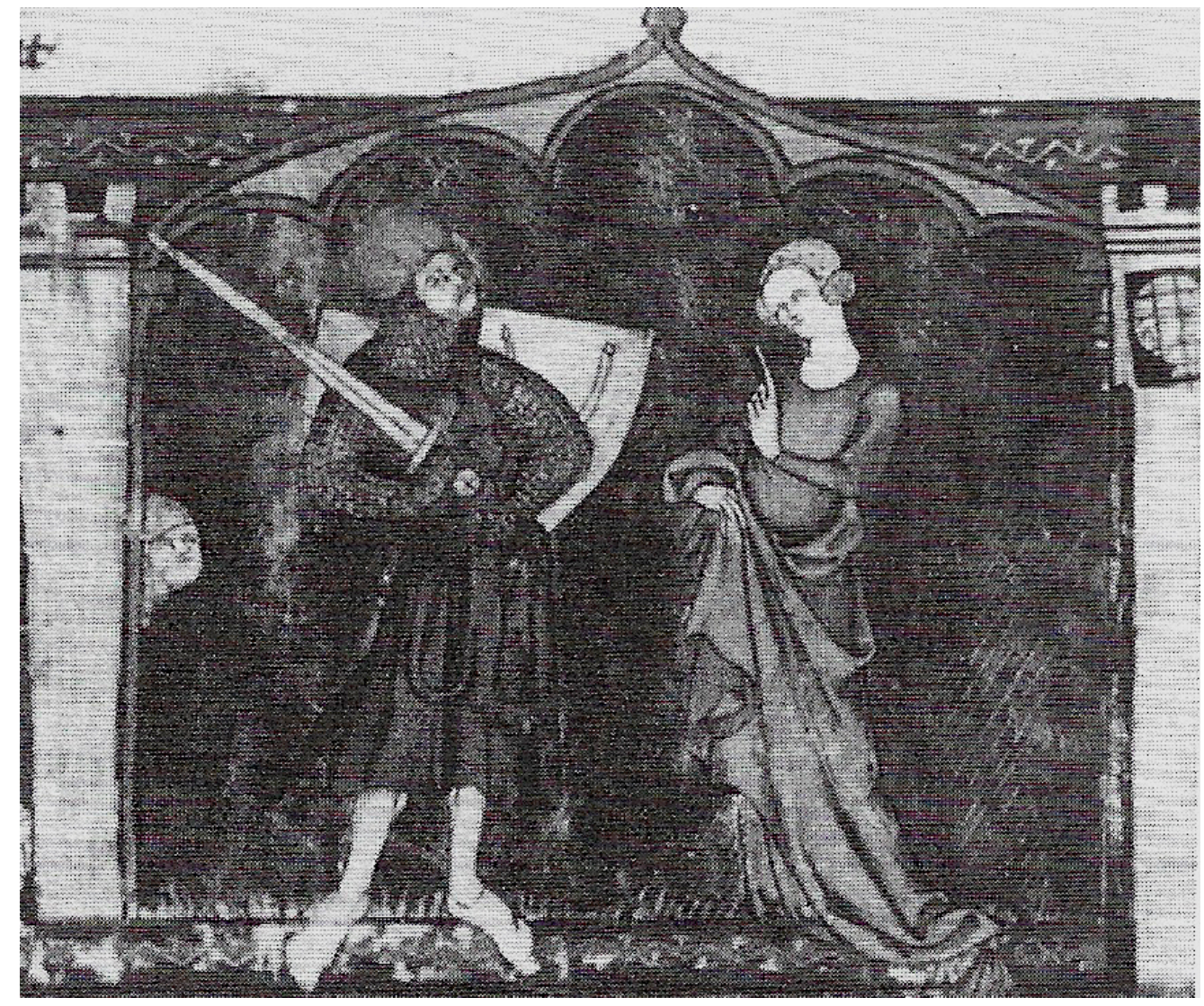

Image 3. Lunete warns against Esclados' grieving subjects. From: James A. Rushing, Images of Adventure: Ywain in the Visual Arts (Philadelphia, University of Pennsylvania Press, 1995), 177. 


\section{NEDERLANDSE SAMENVATTING}

De vertaler als bemiddelaar. Een cross-culturele studie naar de weergave van emoties in de verschillende middeleeuwse versies van het Yvain-verhaal.

Deze dissertatie presenteert de resultaten van een comparatief onderzoek naar de vertolking van emoties in één en hetzelfde Arthurverhaal uit verschillende culturele teksttradities. Het betreft een intertekstuele vergelijking van Chrétien de Troyes' Yvain, ou le chevalier au lion en de verschillende middeleeuwse vertalingen van deze ridderroman op basis van hun zogeheten emotive script. In het bijzonder stelt dit proefschrift de rol van de vertaler centraal in het bemiddelen tussen de taalkundige, culturele en generieke conventies voor de weergave van emoties van de vertaalde en de vertalende traditie.

Emoties zijn rijk vertegenwoordigd in de middeleeuwse Arthurromans. Deze verhalen besteden nadrukkelijk aandacht aan de gedragingen en gevoelsuitingen van personages. Niet alleen vervullen literaire emoties een duidelijke functie binnen de tekst ter motivatie van de verhaallijn, ze faciliteren daarnaast de empathische betrokkenheid van het contemporaine publiek buiten de tekst. Vanwege zijn ontstaansgeschiedenis aan de Franstalige hoven in de tweede helft van de twaalfde eeuw is de Arthurroman vaak beschreven als een afspiegeling van de verfijning van sentimenten die het hofleven in die periode onderging, waarin de bijbehorende emotionele waarden en gedragsvormen van dit hoofse milieu doorklinken.

De literair-historische waarde die om deze reden toegekend kan worden aan het bestuderen van emoties in deze teksten heeft in de afgelopen decennia geresulteerd in een reeks aan verkennende studies naar de presentatie van gevoel, emotie en affect in deze romans in relatie tot hun geïntendeerde publiek. De zogeheten affective turn die plaatsvond in de jaren 
tachtig van de vorige eeuw heeft ervoor gezorgd dat de bestudering van (literaire) emoties een rijk onderzoeksveld is geworden binnen de Mediëvistiek. Het Arthurcorpus van de Franse hofdichter Chrétien de Troyes heeft een belangrijke plek binnen dit onderzoekveld verworven. Chrétien stelt de psychologie en de emoties van zijn personages centraal in zijn verhalen. Zijn werken beschrijven expliciete verbale en non-verbale gevoelsuitingen, die een sterke emotieve potentie hebben. Bovendien zijn deze ridderromans in meerdere Europese verhaaltradities opgenomen, wat een cross-culturele bestudering mogelijk maakt.

Chrétiens Yvain is bij uitstek geschikt voor een dergelijke vergelijkende studie van emotie en vertelling. Het verhaal van De ridder met de leeuw genoot veel succes in de middeleeuwen en werd relatief kort nadat de vertelling in de late twaalfde eeuw werd opgetekend (c. 1170-90) in verschillende volkstalen vertaald. Tussen de vroege dertiende en veertiende eeuw verschenen achtereenvolgens de Middelhoogduitse Iwein (1204), de Oudnoorse-IJslandse Ívens saga (c. 1250), de Oudzweedse Hoerra Ivan (1303), en de Middelengelse Ywain and Gawain (c. 1300-1350). Dit corpus vormt het uitgangspunt voor deze studie. Waar relevant wordt de vergelijking doorgetrokken naar andere ridderromans van Chrétien de Troyes en hun Europese bewerkingen, ter adstructie van generiek bepaalde conventies en receptiegerichte conclusies.

Methodologisch baseert deze studie zich op de nieuwste inzichten in literair-historisch emotieonderzoek, in het bijzonder ten aanzien van literaire emoties en publieksreceptie. Voor deze comparatieve aanpak van 'emotionaliteit' in verschillende versies van één verhaal hanteert deze dissertatie de recentelijk uitgewerkte theoretische benadering van Sif Rikhardsdottir, die stelt dat we middeleeuwse verhalen, zoals dat van de ridder Yvain, kunnen analyseren en vergelijken op basis van een onderliggend emotive script. Een emotive script wordt, samen met het emotie-gerelateerde vocabulaire van een taal, bepaald door generieke conventies voor de manier waarop emoties worden gepresenteerd. Deze zogezegde literaire 
blauwdruk voor de weergave van emoties binnen een bepaald genre stipuleert de vorm (vers/proza), alsook de narratieve strategieën die betekenisvol zijn voor het beoogde publiek van de tekst. Omdat een emotive script afhankelijk is van taalkundige en (sociaal)cultureel bepaalde waarden (emotional codes) kunnen de emotieve vertelwijzen per literaire traditie verschillen. Bij het Noorse saga-publiek, bijvoorbeeld, bestonden andere literaire verwachtingen en voorkeuren dan bij het Franse romanpubliek. Beide publieken benaderen eenzelfde verhaal daarom vanuit een verschillend emotioneel kader, in deze studie aangeduid als horizon of feeling.

Dit betekent dat de overdracht van Chrétiens Yvain in andere Europese teksttradities een confrontatie met alternatieve taalkundige en culturele betekenissystemen met zich meebracht, die beslist ook van emotionele aard was. Dit proefschrift onderzoekt deze tekstuele overdracht (translatio) en verkent wat er gebeurt wanneer de emotive scripts van verschillende literaire tradities met elkaar in contact komen in het proces van intercultureel vertalen. Hoe werd in de verschillende teksttradities omgesprongen met onbekende emotionele voorstellingen in de aanpassing van het Yvain-verhaal aan nieuwe literaire contexten? Welke talige, culturele en/of generieke afwijkingen betreffende de literaire weergave van emotie brengt een vergelijkende close reading van de verschillende verhalen aan het licht? En hoe zijn eventuele onverenigbaarheden tussen emotive scripts omgeschreven tot zinvolle vertolkingen voor het nieuw beoogde publiek?

Deze studie stelt dat de vertaler in dit proces een bemiddelende positie inneemt tussen de emotive scripts van de brontraditie en die van de ontvangende traditie. Deze stelling wordt uitgewerkt in drie comparatieve hoofdstukken, die ieder een opzichzelfstaande casus met een eigen theoretisch kader, analyse en conclusie presenteren. Iedere casus verkent een andere vorm van literaire emotionaliteit binnen de verschillende tekstuele tradities en hun respectieve emotive scripts. 
Het eerste hoofdstuk bestudeert de beeldspraak van de hoofse liefde, typerend voor de Franse traditie waarin Chrétien de Troyes schrijft. Het onderzoekt de weergave van Oudfranse topoi in de Noordse teksttradities in een vergelijking die zich bovenal richt op Ívens saga en waar nuttig wordt doorgetrokken naar de Oudzweedse Hoerra Ivan. De focus van de vergelijking ligt op Chrétiens metaforische voorstellingen van het hart dat, in samenspel met de zintuigen, verantwoordelijk is voor de ontvangst en verwerking van sensaties in personages. Hoe vertolkt de Noorse vertaler, gewend aan een emotive script dat de voorkeur geeft aan een ingetogen en indirecte weergave van emotie, de expressieve en emotioneel intensieve hartmetaforen van zijn/haar Franse bron? Hoe wordt het cuer (hart), dat in semantisch profiel afwijkt van de cultureel bepaalde Oudnoorse vertaling hugr (geest), weergegeven in deze vertolking?

Hoofdstuk 2 verkent eveneens Yvains emotive script voor de hoofse liefde, dit keer in vergelijking met dat van de Middelhoogduitse Iwein. Waar hoofdstuk 1 inzoomt op de innerlijke gevoelswereld van personages, toont hoofdstuk 2 de fysieke manifestatie ervan middels lichaamstaal. Gesticulatie vormt een voornaam onderdeel van het emotive script van de hoofse roman. Als aanvulling op- of zelfs geheel ter vervanging van spraak, vervulde gebaren een belangrijke functie bij het verhalen van emotie. Deze casestudy onderzoekt welke literaire conventies en emotionele codes ten grondslag liggen aan de gewijzigde verzoeningsscène aan het einde van Iweins B-redactie, waarin de gevoelsuitingen van het liefdespaar in spraak en gebaar significant verschillen van zowel de Franse tekst als de Duitse A-variant. Het hoofdstuk biedt daarnaast inzicht in de filologische- en receptiegerichte vraagstukken die dit alternatieve einde oproept.

Naast het bestuderen van de emoties van individuele personages in de eerste twee hoofdstukken, exploreert hoofdstuk 3 de weergave van groepsemotie, een recent onderwerp van interesse in literair-historisch onderzoek. De casestudy spitst zich toe op aankomstscènes 
in de episodische structuur van de roman en onderzoekt hoe en waarom the communal feeling (het gemeenschappelijke gevoel) geënsceneerd en geëxploiteerd wordt in Yvain, Ívens saga en de Middelengelse Ywain and Gawain. Met name in aankomstscènes wordt de gemeenschap (het hof, de stedelingen of subgroepen hierbinnen) uitgenodigd om de identiteit van de protagonist in de groep te bevestigen, of omgekeerd, in twijfel te trekken. Deze emotionele appraisals (evaluaties) worden in de Franse bron vaak meermaals herhaald en zijn daarom belangrijk voor hun emotieve effect op de lezer/toehoorder. De Oudnoorse en de Middelengelse versies staan bekend om hun vergelijkbare emotive script; beide is een samenvattende stijl toegeschreven ten aanzien van repetitieve elementen die het vlotte verloop van het verhaal belemmeren. Deze casus stelt daarom de vragen centraal: Hoe wordt in beide tekstuele tradities omgegaan met dergelijke herhaalde emotionele voorstellingen die de verhaallijn onderbreken? Zijn er overeenkomsten aan te wijzen in de manier waarop deze vorm van groepsemotie is aangepast voor het beoogde publiek?

De introductie en conclusie zijn gewijd aan het theoretisch raamwerk dat de onderlinge casestudies verbindt. De inleiding bespreekt de verschillende methodologische concepten waarmee in de hoofdstukken aan de slag wordt gegaan. Het geeft allereerst een overzicht van het denken over passies en emoties sinds de Oudheid en bespreekt de belangrijkste emotietheorieën in de geschiedenis van het emotieonderzoek. In deze sectie wordt tevens ingegaan op de relatie tussen zogenoemde 'literaire emoties', te onderscheiden van 'echte emoties', en op de vraag hoe wij als lezer/toehoorder (emotieve) betekenis geven aan verhalen. Zowel de neurobiologische mechanismen als de sociaal-culturele conditionering die beide een belangrijke rol spelen bij tekstbeleving, komen aan de orde. Het is ditzelfde interpretatieve kader dat we als mens meedragen dat een rol speelt bij de vorming van emotive scripts. 
Aansluitend biedt de inleiding een uitgebreide bespreking van het corpus. Zij voorziet de diverse Yvain-tradities van historische achtergrond en plaatst de teksten in hun sociaalculturele context. De sectie geeft bovendien inzicht in de verspreidingsroute van het verhaal over de ridder met de leeuw over Europa. In het bijzonder wordt de onderlinge relatie tussen de verschillende vertolkingen belicht, aan de hand van de termen source (bron) en translation (vertaling), die methodologisch gewogen worden. Met het oog op het beschrijven van middeleeuwse tekstoverlevering en vertaalpraktijken wordt het concept translatio belicht, wat leidt tot inzicht in het overdrachtsproces en de menselijke tussenkomst hierin.

De slotbeschouwing evalueert de gekozen theoretische en methodologische aanpak van het onderzoek en vat de resultaten van het proefschrift samen. Aan de hand van de drie besproken casussen benadrukt de conclusie de discrepantie die er blijkt te bestaan tussen middeleeuwse en moderne vertaalopvattingen. Daarbij wordt ook gereflecteerd op de problematiek rondom brongetrouwheid en de terminologische discussie betreffende de benamingen bron en vertaling/adaptatie/herschrijving. Hoewel men er in een vergelijkende studie als deze niet aan ontkomt deze moderne termen toe te passen (zonder daarbij de onderlinge relatie van de teksten uit het oog te verliezen), kan de manier waarop de verschillende Yvain-vertolkingen de emotionele inhoud van Chrétiens tekst overbrengen uiteindelijk niet in dergelijke eenduidige termen worden samengevat. Het proefschrift stelt om die reden dat in plaats van de focus te leggen op het vertaalproduct, we er beter aan doen om het vertaalproces nader te bestuderen.

Dit vertaalproces lijkt meer doordacht dan tot nu toe is aangenomen. We blijken niet enkel te kunnen spreken van enerzijds getrouwheid aan- en anderzijds het verwerpen van de brontekst; van enerzijds de adoptie van de taalkundige- en culturele codes van Yvains emotive script en anderzijds de afwijzing ervan. In plaats daarvan berust iedere vertaling op unieke vertaalkeuzes die bedoeld zijn om de culturele kloof tussen emotive scripts te dichten. Door 
de teksten naast elkaar te leggen komen de obstakels in het samenbrengen van emotive scripts aan het licht. De verschillende versies van het Yvain-verhaal helpen daarom elkaar te begrijpen. Het is immers juist door hun transformatie te bestuderen dat deze middeleeuwse emotionele voorstellingen inzichtelijk worden voor de moderne lezer. 


\section{ACKNOWLEDGEMENTS}

The completion of this $\mathrm{PhD}$ thesis is unquestionably a shared victory. Thanks are due to many and I would like to start by offering my heartfelt gratitude to my supervisory committee for the encouragement, intellectual generosity and patience that they've showed me over these past few years. I warmly thank all three supervisors for their invaluable advice, suggestions, and show of enthusiasm.

Dr. Frank Brandsma has helped me navigate Arthurian scholarship since my very beginnings in academia and has introduced me to Emotion Studies. Simply put: Would it not have been for you, Frank, this dissertation would not have been written. Its foundation was laid during you supervision of my MA thesis, a comparative study that likewise focused on emotions in several versions of the Yvain story. Thank you for sharing your enthusiasm, knowledge, and excellent taste in fantasy fiction with me, for supporting my research ambitions over the years and for encouraging me to pursue a joint doctorate.

Crucial in realising this dual degree has been the help and support of Prof. dr. Sif Ríkharðsdóttir. I am greatly indebted to her for encouraging me to apply for a doctoral grant at the University of Iceland, even though we had never actually even met. Thank you, Sif, for sharing your work and knowledge so readily with me. Your writing has always been hugely inspirational, as this dissertation attests to.

The critical, yet benevolent approach of Prof. dr. Bart Besamusca, has been imperative in framing and writing this thesis. Bart, thank you for your judicious advice on my chapters and for the warm-hearted encouragements and show of support that I've received from you during COVID-19 lockdowns. Your offerings of a sympathetic ear and even a study space in your home when the university was closed went well beyond the call of duty. 
This dissertation would not have come about without the financial support of the University of Iceland Research Fund and of the international research project 'Voice and Emotion in Medieval Literature' (2013-2017), led by Sif Ríkharðsdóttir and funded by the Icelandic Research Fund (Rannís). My sincerest gratitude goes out to both funding bodies.

For their constructive feedback on some of my papers and articles and their inspiring work within Arthurian Emotion Studies, I sincerely thank Prof. dr. Carolyne Larrington and Prof. dr. Andrew Lynch. I also owe a debt of gratitude to Prof. dr. Paul Wackers, who annotated the first drafts of my research proposal; to Prof. dr. Keith Busby for being so kind as to send me his copy of the Medieval Garland Yvain edition, my go-to edition; and to Prof. dr. Jozef Janssens for sharing an inspiring photo with me that not only makes a great cover image for this study, but, more importantly, reaffirms the notion that emotion plays a central role in Arthurian romance.

For helping me out with the Icelandic summary of the thesis, I am moreover grateful to Inga Magnúsdóttir. Lastly, I wish to extend my sincere thanks to $\mathrm{PhD}$ coordinators María Gestsdóttir and Hanneke Jansen, for answering my endless lists of questions regarding the joint doctorate; to Simone Veld, Amira Goossens en Paula Meesters for their ready support at times when it was most needed.

I would like to thank the department of Middle Dutch for including me in their lunches, activities, and overall merrymaking. Bart, Dieuwke, Martine, Andrea, Irmgard, Jelmar, Cécile, David, Lisa, and Jenneka, thank you for brightening my time at the Utrecht office. A special thanks to Irmgard for de schouderklopjes; to Rozanne for our coffee breaks and for inviting me into your classroom as a guest teacher; to Andrea, for visiting me in Reykjavík; to Kila for our poetry talks; and to Sophie and Hsin-lin Su, my 'roomies', for offering laughs and, occasionally, a sympathetic ear. 
Brenda and Maria, our Tuborg nights at the Stúdentakjallarinn or in downtown Rekjavík were a welcome source of distraction and provided the healthy outlet that was at times much needed. Sonja, Babette, Myrthe, thank you for our long-standing friendship. No matter where we live, we always manage to connect with each other, whether through cards, hours-long phone calls, or flying half way across the world to meet for a New York minute. Indispensable support has come from the girls of Allura, who have been supporting me with sound advice and laughter ever since we started university together in Utrecht. Thank you to my paranymphs, Myrthe and Carlijn, who to me represent female strength and who greatly inspire me with their kindness and courage.

Finally, my family deserves a huge thanks. Thank you, mom and dad, for your unfailing love and your presence and support throughout; and to my parents-in-law, Suzanne and Pierre, for your ever-ready interest in my studies. Valentino, Brüderchen, your empathy and words of motivation in the final stages of completing the thesis have meant a lot, as has Carmen's. Charlie, 'auntie's favourite', your fledgling smile brightens up my world. And then, Bram, my constant aid and ally, always willing to share in the emotional strain that comes with going through the motions of a PhD trajectory. Thank you for ALWAYS being understanding of my at times physical, if not mental absence over the past few years, for looking after our two fur babies, and for simply holding down the fort.

Niets dan jij. 


\section{CURRICULUM VITAE}

Chloé Henrica Anna Gerarda Vondenhoff was born in Heerlen, the Netherlands, in 1988. She obtained her BA in English Language and Literature from Utrecht University (2010) and completed a minor in Medieval Studies and in Celtic Languages and Culture at the National University of Ireland. She holds a RMA in Medieval Studies from Utrecht University, from which she graduated cum laude in 2013. As part of her academic training, Chloé worked as a teaching assistant at Utrecht University (Taal- en cultuurstudies) (2010), as a research assistant at the department of Special Collections of Utrecht University Library (2011), and was a board member of Firapeel, former Student Society for Medieval Studies (2012-2014).

Before starting her doctoral studies, Chloé worked as an editorial assistant with publishing house Prometheus | Bert Bakker in Amsterdam and as a freelance writer/translator/editor for, among others, publishing house Matrijs and WNF. She, furthermore, wrote (academic) book reviews for the online platforms Jonge Historici and Literair Nederland.

Chloé started her doctoral trajectory in Reykjavík at Háskóli Íslands as part of the international research project 'Voice and Emotion in Medieval Literature' (2013-2017), led by Prof. dr. Sif Ríkharðsdóttir and funded by the Icelandic Research Fund (Rannís). The remainder of her studies were funded by a personal grant from the University of Iceland Research Fund. Her doctoral studies are part of a Joint Doctorate between Utrecht University and the University of Iceland and Chloé has alternately studied and taught at both universities. Over the years, she has published several articles with Arthuriana, Madoc and Archeobrief (now: Archeologie in Nederland), a co-authored study with Utrecht University Library, and has contributed a book chapter for MIP, De Gruyter. 